\title{
EL CONFLICTO ARMADO EN COLOMBIA EN DOS NOVELAS JUVENILES. PROPUESTA DE UNA SECUENCIA DIDÁCTICA
}

\author{
CARlos Fernando SÁnCHEz Lozano \\ TRABAJO DE GRADO PARA OPTAR POR EL TÍTULO DE \\ MAGÍSTER EN ESTUDIOS LITERARIOS
}

\author{
UNIVERSIDAD SANTO TOMÁS \\ FACULTAD DE FILOSOFÍA Y LETRAS
}

BOGOTÁ

2016 


\title{
EL CONFLICTO ARMADO EN COLOMBIA EN DOS NOVELAS JUVENILES. PROPUESTA DE UNA SECUENCIA DIDÁCTICA
}

\author{
CARlos Fernando SÁnCHEZ Lozano \\ TRABAJO DE GRADO PARA OPTAR POR EL TÍTULO DE \\ MAGÍSTER EN ESTUDIOS LITERARIOS
}

\author{
DIRECTOR: RUBÉN DARÍO VALLEJO \\ MAGÍSTER EN EVALUACIÓN EN EDUCACIÓN
}

UNIVERSIDAD SANTO TOMÁS

FACULTAD DE FILOSOFÍA Y LETRAS

BOGOTÁ

2016 
NOTA DE ACEPTACIÓN

\section{FIRMA DEL PRESIDENTE DEL JURADO}

FIRMA DEL JURADO

\section{FIRMA DEL JURADO}

BOGOTÁ, ABRIL 20, 2016 
EPÍGRAFES

El niño que fui llora en la calzada.

lo dejé allí cuando llegué a ser quien soy;

mas hoy quiero, viendo que soy nada, ir a buscar aquel que fui donde quedó.

Fernando Pessoa

La pasión es siempre el índice de lo que hay que hacer, pero también de aquello a lo que hay que renunciar.

Ernst Jünger 
DEDICATORIA

A la memoria de mi madre, María Ligia Lozano Ramírez (1927-2012)

A los niños y jóvenes víctimas del conflicto armado en Colombia 


\section{Agradecimientos}

Primero que todo quiero agradecer a Deyanira Alfonso Sanabria (sans vie nord) sin cuya presencia este trabajo investigativo no hubiera podido ser realizado. Escribir una investigación de posgrado es, esencialmente, un ejercicio de inmersión intelectual y silencio. Durante cerca de tres meses he estado tranquilo leyendo, tomando notas, escribiendo, con la garantía de que una voz -su presencia humana e intelectual- estaba de interlocutora. Las sugerencias, el diálogo, a veces las diferencias, enriquecieron lo que tenga de bueno este trabajo. A mi bella amada, gracias.

En segunda instancia quiero agradecer su apoyo y disposición al diálogo a esas gran escritoras que son Irene Vasco y Pilar Lozano, a quienes quiero y admiro. Mis respetos. Por su humanidad, su valentía, su amor por este país al que recorren todo el tiempo. Por esas dos maravillosas novelas que me han servido para entender el sufrimiento de los niños y jóvenes que han vivido la guerra de este país en carne propia.

En la maestría, mis agradecimientos a su director Carlos Bernal, quien facilitó todo para mi ingreso y ha sido permanente animador para que me convierta en investigador juicioso. A mi tutor, mi amigo y compañero, el paciente Rubén Darío Vallejo, que puso orden al caos. A mi maravilloso grupo de compañeros de la cohorte 2013-2, en especial a Aura Pérez, Ana Milena Pinzón, Carlos Salgado. Gracias por los dos años, esforzados pero divertidos. A varios docentes, cuyo voz e ideas espero reconozcan aquí. En especial, Ofelia Ros, María Cristina Sánchez, Eleonora Guerrero, Jorge Iván Parra, César Vásquez y Luis Felipe González. Todos muy pacientes con este estudiante cincuentón fastidioso que a veces soy.

A mis queridos maestros Pedro Agustín Díaz (fallecido el pasado 24 de diciembre de 2015) y Rubén Jaramillo Vélez, a quienes fundamentalmente les debo haber aprendido a escribir y que, incluso, fueron más allá y me publicaron. Dios, solo hasta los 20 años, como estudiante de Derecho en la Universidad Nacional, pude escribir gracias a ellos una oración sintácticamente de modo correcto.

Mi agradecimiento al grupo de colegas de la Licenciatura en Lengua castellana y Literatura, de la Vuad, Paola Moreno, Massiel Mossos, Nirza Chacón, Óscar Rincón, Andrés Ordóñez, con quienes organizamos, durante el primer semestre de 2015, una tertulia dedicada al conflicto armado en la literatura colombiana. También a los estudiantes que participaron 
activamente en el proyecto. Varias de las ideas que allí se plantearon como hipótesis, espero haberlas respondido en esta investigación.

A Alice Castaño y Silvia Valencia, en Cali, que hicieron una magnífica investigación sobre violencia en la literatura infantil colombiana, que me ayudó en mucho a enfocar la mía.

A Claudia Guerrero y al grupo de docentes del Liceo Cambridge, en La Calera, integrantes del grupo "Escribir como lectores", por su generosidad al haber acogido y desarrollado algunas de las actividades de la Secuencia didáctica presentada en esta investigación.

A mis queridos amigos Jesús Luis Mendoza, Mario Ramírez, Blanca González, Nancy Cárdenas, William Sierra, Jairo Garzón, Mariela González, que me acompañaron con su diálogo, sus comentarios e ideas críticas.

Mi agradecimiento a la Biblioteca Luis Ángel Arango, sin cuyo catálogo y servicios, ninguna investigación es completa.

Gracias al regalo divino de la esperanza, a la luz de cada mañana, al primer café. 


\section{Resumen}

Esta investigación explora la posibilidad de introducir didácticamente el tema del conflicto armado en las aulas a partir de la lectura de dos novelas escritas principalmente para jóvenes. Con ello se quiere enviar el mensaje, fundamentalmente ético, de que la literatura también tiene responsabilidades, y que somos los maestros de literatura, de primaria y secundaria, los primeros intelectuales que estamos a cargo de recuperar la memoria de las víctimas de esta guerra que ya alcanzó los cincuenta años.

Muchos jóvenes de Bogotá y de las ciudades más grandes han visto la guerra por televisión. La lectura de grandes obras literarias como Paso a paso, de Irene Vasco, y de Era como mi sombra, de Pilar Lozano, quizá pueda contribuir a entender que, al contrario de lo que se cree ("la violencia pasa en otro lado"), la guerra es un tema que nos involucra a todos (porque todos somos colombianos y compartimos una historia, una cultura y una geografía común) y que no podemos dar la espalda a los que han sufrido el horror.

Este trabajo consta, sustancialmente, de dos partes, una teórico-literaria, y la otra didáctica. En la primera se hace una interpretación detallada (con gran apoyo intertextual) de las dos novelas objeto del estudio. En la segunda, se propone una estrategia de intervención pedagógica, conocida como secuencia didáctica, que busca desarrollar en los estudiantes competencia literaria y una competencia ciudadana central para comprender los efectos feroces del conflicto armado: la empatía.

Este trabajo aprovecha los resultados de otras investigaciones que han sido publicadas en los dos últimos años, sobre todo provenientes de las ciencias sociales. En este sentido, es interdisciplinaria.

La investigación se presenta en un momento coyuntural que consideramos relevante -marzo de 2016-, cuando se discute en La Habana un posible acuerdo de paz con uno de los grupos alzado en armas. Los docentes de lengua y literatura en educación secundaria y sus estudiantes requieren información contextualizada y este trabajo podría darles herramientas para comprender lo que está sucediendo.

Palabras clave: Conflicto armado, novela juvenil, secuencia didáctica, competencia literaria, competencias ciudadanas (empatía). 


\section{Contenido}

$\begin{array}{ll}\text { Presentación } & 11\end{array}$

$\begin{array}{ll}\text { INTRODUCCIÓN } & 15\end{array}$

CAPÍTULO 1. CONFLICTO ARMADO, NOVELA JUVENIL Y COMPETENCIA LITERARIA

El conflicto armado en Colombia $\quad 26$

La novela juvenil como género literario 32

El lugar de la literatura juvenil en el currículo: la competencia literaria 39

Integración de las competencias ciudadanas en la valoración literaria $\quad 49$

Capítulo 2. Ficcionalización del SECUeStro en Paso a PASO, DE IRENE VASCO

Ficha del libro $\quad 54$

Biografía de la autora $\quad 54$

Contexto histórico $\quad 55$

$\begin{array}{ll}\text { Argumento de Paso a paso } & 65\end{array}$

$\begin{array}{ll}\text { Paratextos destacados } & 67\end{array}$

$\begin{array}{ll}\text { Fragmento de la obra } & 70\end{array}$

$\begin{array}{ll}\text { Análisis crítico } & 73\end{array}$

CAPÍTUlo 3. FiCCIONALIZACIÓN DEL RECLUTAMIENTO ILÍCITO DE

MENORES EN ERA COMO MI SOMBRA, DE PILAR LOZANO

$\begin{array}{lr}\text { Ficha del libro } & 86\end{array}$

$\begin{array}{ll}\text { Biografía de la autora } & 86\end{array}$

$\begin{array}{lr}\text { Contexto histórico } & 88\end{array}$

$\begin{array}{ll}\text { Argumento de Era como mi sombra } & 103\end{array}$

$\begin{array}{ll}\text { Paratextos destacados } & 110\end{array}$

$\begin{array}{ll}\text { Fragmento de la obra } & 112\end{array}$ 
$\begin{array}{lr}\text { Análisis crítico } & 119\end{array}$

$\begin{array}{ll}\text { Colofón } & 138\end{array}$

Capítulo 4. Propuesta de Secuencia didÁctica (SD) con BaSe

EN ERA COMO MI SOMBRA

La SD como dispositivo pedagógico para la enseñanza de la literatura $\quad 140$

Desarrollo de la secuencia didáctica "Los niños de la guerra en Colombia" $\quad 148$

$\begin{array}{ll}\text { Sesión 1. Lectores y textos se acercan } & 148\end{array}$

$\begin{array}{lr}\text { Sesión 2. Los paratextos } & 149\end{array}$

Sesión 3. La autora $\left(1^{\mathrm{a}}\right.$ parte $) \quad 151$

Sesión 4. La autora (2 $2^{\mathrm{a}}$ parte) 152

Sesión 5. Consulta de información extratextual 153

Sesión 6. Red textual y lecturas paralelas $\quad 155$

Sesión 7. Juego de roles y lectura del capítulo 1 de Era como mi sombra 157

Sesión 8. Primera lectura de la novela. Lectura cuasiespontánea 163

Sesión 9. Ficha de personaje y centración en aspectos locales del texto 169

Sesión 10. Verificación de dominio de las habilidades de comprensión textual $\quad 174$

Sesión 11. Desarrollo de la lectura crítica. Escritura de un comentario ( $1^{\mathrm{a}}$ parte $) \quad 180$

Sesión 12. Desarrollo de la lectura crítica. Escritura de un comentario ( $1^{\mathrm{a}}$ parte) $\quad 184$

Sesión 13. Construcción de competencias ciudadanas: empatía 188

$\begin{array}{ll}\text { CONCLUSIONES Y RECOMENDACIONES } & 194\end{array}$

$\begin{array}{ll}\text { BIBLIOGRAFÍA CONSULTADA } & 198\end{array}$

ANEXos

Anexo 1. Estado del arte sobre el conflicto armado en la literatura juvenil $\quad 210$

Anexo 2 Entrevistas realizadas a Irene Vasco y Pilar Lozano 215

$\begin{array}{lr}\text { Anexo 3. Índice de esquemas, cuadros e imágenes } & 219\end{array}$ 


\section{Presentación}

Todavía recuerdo la mañana de mayo de 2002 en que iba en un bus de Transmilenio y oí en radio la noticia de la masacre que las Farc habían cometido en Bojayá (Chocó): 79 personas, afrodescendientes, habían sido asesinadas. 48 eran niños. Llevaba en mi maleta Antígona, a la que había vuelto a releer por esos días. El locutor de la emisora decía que el enfrentamiento entre la guerrilla y los paramilitares impedía aún que los cadáveres pudieran ser recogidos y sepultados. Antígona se repetía en Colombia. La literatura venía en mi auxilio para tratar de entender el horror.

No pude llorar porque iba en un transporte público, pero ese día también murieron en Colombia muchas cosas, y en mí varias. Una de ellas fue la idea de que la violencia aportaba algo a las soluciones del país. Yo mismo, a finales de los años 80 -mientras que era estudiante en retiro de la Universidad Nacional y empezaba mi carrera de editor de libros educativos- y acompañaba las marchas con los cadáveres ora de José Antequera, ora de de Bernardo Jaramillo, ora de Carlos Pizarro, y gritaba consignas contra el gobierno, había contemplado la posibilidad de validar que solo con violencia se podía responder a la violencia.

En ese temible 2002 hubo 160 masacres, la mayoría de humildes labriegos, cometidas por los paramilitares de derecha, cercanos a la ideología del presidente de la república. Pero también las guerrillas izquierdistas ponían su parte: ese año secuestraron a 3.000 personas y habían reclutado para la guerra - contra toda prohibición del derecho internacional humanitario- a más de 2.000 niños y jóvenes. (GMH, 2013, p. 48, 65).

Tuvieron que pasar doce años más, cuando como estudiante de la Maestría en Estudios Literarios de la Universidad Santo Tomás, tomé la decisión de incluir dentro de mis intereses académicos la preocupación por el conflicto armado y por estudiar con más atención la literatura juvenil que lo había reflejado literariamente. Quería con ello pagar mi deuda con aquel dolor que sentí esa mañana de mayo de 2002.

Pese a que en Colombia no existe - a diferencia de Argentina con los hechos de la dictadurauna cátedra en educación secundaria sobre el conflicto armado ${ }^{1}$, sí considero importante que este tema se incluya dentro del currículo, al menos el de lengua y literatura. Me parece que

1 Una columna reciente en El Espectador plantea si no habría que hacerlo ya. Recuperado de: http://bit.ly/1LFWoJf 
las víctimas (en particular los niños y jóvenes víctimas) merecen ese homenaje. Y no por la bondad distanciada de la que a veces hace gala la academia, sino porque las víctimas nos dan la perspectiva de lo que pasó, pero también de lo que vendrá. En palabras de Walter Benjamin, citado por Reyes Mate (2011): "La memoria abre expedientes que la ciencia da por archivados". (p. 165).

En tal sentido considero que la literatura -novela, teatro, cómics, poesía, cuento, relato oralnos puede dar luces. La literatura toca lo humano, lo que nos hace humanos, lo que nos une como humanos. Si el lenguaje, en la citada frase de Heidegger, es el que nos constituye, somos los maestros de lenguaje los que tenemos que velar porque el lenguaje de la ignominia que generó el conflicto armado no desaparezca en el velo de los tiempos.

Esta investigación, entonces, une dos preocupaciones. Una, ahondar en el estudio de la literatura para niños y jóvenes producida en Colombia entre 1980 y 2015 que toca el tema de la guerra. La otra, determinar cómo esa literatura se podría asentar en el sistema escolar. En relación con esto esto último sé que es complejo (habrá docentes que volteen el rostro cuando se toque el asunto), pero cuando ingresé a la Maestría en 2013, para mí era claro -y así se lo manifesté al director, Carlos Bernal- que la literatura infantil y juvenil tenía derecho a ser estudiada académicamente e incluida como parte del currículo, pues es la literatura de la escuela, la literatura con la que los maestros de lengua y literatura, de primaria y secundaria, tenemos que vérnoslas todos los días.

Y los Lineamientos para la investigación (2013) de la maestría creo que vienen en mi ayuda cuando plantean estas preguntas:

¿A qué se hace referencia cuando se habla de la literatura? ¿Es posible "enseñar" literatura? ¿Cómo abordar la selección de los textos en este campo de lo "literario"? ¿Y a partir de qué criterios? ¿Cuál es el canon de lecturas que los profesionales en literatura reproducen en las aulas y en las planificaciones? ¿Y por qué? ¿Qué leer y cómo hacerlo? ¿Qué escribir y cómo hacerlo? (p. 22).

Esta investigación, pues, pretende dar una respuesta -así sea parcial- a esos interrogantes, además de invitar a otras instancias académicas a que incluyan el conflicto armado en sus ejes de investigación. 
Me une a este objetivo, además, el amor que tengo por mi país (ay, mi delirante país), por conocerlo y describirlo, y el espíritu crítico de Fray Antón de Montesinos cuando reclamó respeto y dignidad para los más humildes:

¿Con qué autoridad habéis hechos tan detestables guerras a estas gentes, que estaban en sus casas y tierras, mansas y pacíficas?... Cómo los tenéis tan opresos y fatigados, sin darles de comer ni curarlos en sus enfermedades, que de los excesivos trabajos que les dais incurren y se os mueren, y, por decir mejor, los matáis por sacar y adquirir oro cada día? (citado por Henríquez Ureña, 1978, p. 21).

Las novelas realistas tienen el defecto de ponernos ante un espejo crítico con respecto a lo que está sucediendo en la actualidad. Las dos que he incluido en mi estudio-Paso a paso, de Irene Vasco, y Era como mi sombra, de Pilar Lozano- golpean a los lectores por lo dramático de sus historias, pero también los invitan a pensar si no es necesario hacer algo por los niños y jóvenes que han vivido la guerra en nuestro país. Creo que la literatura no es un placer (o al menos no para mí), sino una forma de configurar la subjetividad que nos ayuda a dar cohesión, cognitiva y emocional, a una realidad abstracta. Todo ello está como intención subyacente tras las palabras que vienen a continuación en cada capítulo de la investigación. Me uno a Michèle Petit (2015), entonces, cuando resalta el poderoso valor de la lectura literaria:

La lectura recibe su dignidad de los pensamientos que despierta, decía Proust. Para él, era "la iniciadora cuyas llaves mágicas nos abren en nuestro interior la puerta de estancias a las que no hubiéramos sabido llegar solos". Él evocaba la figura de un ángel que abre puertas, luego inmediatamente levanta vuelo, momentos de gracia en los que alcanzaría la quintaesencia de la vida. (p. 69)

Yo nací en 1964, el año en que las Farc fundaron su primer reducto rebelde en Marquetalia (Caldas). Tras 50 años de guerra al establecimiento, de utopías planeadas y sueños frustrados, los logros son mínimos, en mi opinión. Quedan las huellas devastadoras del conflicto armado, el lastre de nuestra generación.

Que esta investigación quede como prueba de que las “terribles acciones” (Jünger, 2003, p. 104) cometidas por todos los actores vinculados al conflicto armado (incluido el propio 
Estado) no serán olvidadas y que unirnos a la memoria de las víctimas nos ayudará en la redención de esta tragedia. 


\section{Introducción}

El modo en que la literatura representa los hechos históricos es toda una veta de análisis teórico que desde diferentes orientaciones -formalistas o sociologistas- dan cuenta de esa relación. ¿Las obras literarias qué toman de la historia? ¿Por qué lo hacen? ¿Qué efectos causa en la literatura esa representación de los hechos históricos?

Con gran razón Jacques Rancière (2009) ha cuestionado la tradicional forma como los teóricos -sobre todo marxistas y los neokantianos- han establecido la relación entre arte y política. Todo arte -incluso el arte literario- es forzosamente político, esto es, una práctica social y estética mediada por lo que él llama "reparto de lo sensible". Este "reparto" de lo sensible objetiva las relaciones entre los textos estéticos y lo que los sujetos hacen con ellos. Esta "repartición" no es neutral: alguien ve, alguien dice y asume la competencia para decirlo (p. 10). Hablamos, entonces, no de cómo el arte refleja la vida (o viceversa) sino de cómo explica una experiencia político-estética determinada ${ }^{2}$.

En esta investigación se disertará sobre lo que significa una experiencia de lo político, vista a través de la narrativa de ficción destinada fundamentalmente a ser leída por los jóvenes. Nos enfocaremos en cómo dos obras pueden dar cuenta de una experiencia de lo político en un momento determinante de la historia de Colombia con el que tenemos que saldar cuentas (es decir, reconstruirlo).

El Frente Nacional, ese calculado acuerdo entre las élites liberal y conservadora firmado en 1959 y que se prolongó formalmente hasta 1974, no solo cerró las opciones a otros modos de hacer política diferentes a los que ellos establecieron, sino que instituyó un modo de convivencia en la sociedad civil colombiana que como un guion atroz escrito por el Mal se ha cumplido a lo largo de más de 50 años. Un modo de convivencia basado en la exclusión del débil y el humilde, el desconocimiento del Otro -de lo Otro-, en atacar las posibilidad de subjetividad laica que consolidaron la Revolución Francesa y la Reforma protestante, y en eliminar física o simbólicamente al que piensa diferente al poder.

Ha sido Rafael Gutiérrez Girardot en un ensayo de título diciente: "Estratificación social, cultura y violencia en Colombia” (2005, p. 86), quien ha culpado a la conciencia hispano-

\footnotetext{
${ }^{2}$ Me parece que Rodríguez Freire (2010, p. 93) hace bien en denominar este "reparto de lo sensible" como un "nuevo régimen de visibilidad".
} 
católica contrarreformista de la incapacidad colombiana para entrar a la Modernidad. Si bien es claro que las relaciones de connivencia entre la Iglesia y el Estado se prolongaron durante más de cien años (desde la Constitución de 1886 hasta la Constitución de 1991), los efectos letales del dogma, de la fe, del peso eclesiástico persisten. Muchos de los argumentos que hoy se esgrimen para descalificar al homosexual o a la mujer que libremente desea abortar tienen antecedentes en documentos papales de hace cuatro siglos. Colombia, pues, sería el país donde los dogmas eclesiásticos se citan como fuente de autoridad. Esto ha generado una actitud donde escasean la razón, el argumento, el diálogo, el respeto a las ideas del otro. Educados en las preguntas y respuestas dogmáticas del Padre Astete (iba a decir Astuto) se consolidó a lo largo del siglo XX una mentalidad de "pisar al otro", no crear -para qué, como diría Unamuno, "que creen los otros"-, la propensión a la docilidad doméstica, al atajo y a ser taimados como formas de sobrevivencia. Una conciencia que Gutiérrez Girardot, citando al historiador Jaime Jaramillo Uribe, caracteriza como mediocre: "Colombia bien puede ser llamada el país americano del término medio, de la aurea mediocritas" (Gutiérrez Girardot, 2005, p. 86).

Esta mediocridad o impotencia de construir programas propios para consolidar la Modernidad ha sido sustituida por un estilo de organización social piramidal y excluyente, celebrado como logro incluso por historiadores académicos como Jorge Orlando Melo o Marco Palacios ${ }^{3}$. La forma de garantizar que esa estructura se legitimara se llevó a cabo mediante diferentes formas de violencia, siendo la más grave la de descalificar a la persona de ideología diferente a la liberal-conservadora, como comunista o "terrorista", según denominación de un expresidente de ingrata recordación.

Está violencia - de derecha y también de izquierda- valida su uso acudiendo al argumento de que todo se hace en nombre del "bien de los colombianos", acompañada de la descalificación radical: si no está de acuerdo conmigo, hay que obligarlo a cambiar. Y si no cambia, asústelo. Y si no se asusta, mátelo. El degollamiento, la desmembración del cuerpo, la violación sexual de las mujeres y las niñas, la matanza de campesinos, el desplazamiento forzado, el secuestro, entre otras formas de "matar, rematar y contramatar" (en expresión de la antropóloga María

\footnotetext{
${ }^{3}$ Este último dijo del Frente Nacional: "Civilizó las costumbres políticas colombianas”. Citado por Sánchez Lozano (1998, p. 389).
} 
Teresa Uribe) sellan un pacto forzado de convivencia en Colombia, un modo de vivir y de pensar internalizado en el día a día.

Sin duda alguna estas formas extremas de ataque al Otro y de violación de derechos fundamentales tienen raíces económicas y de clasismo ideológico en la Colonia y en los primeros años de la República en el siglo XIX, pero se establecieron institucionalmente con ese pacto de caballeros de las oligarquías colombianas que comenzó en 1959 y que tuvo su primer revés cuando en 1964 un grupo de campesinos comandado por un antiguo guerrillero liberal, se alzaron en armas contra el Estado. Con ellos, 50 años después, está el establecimiento negociando un acuerdo en búsqueda de un país donde quepamos todos.

Estas formas de violencia no podían ser pasadas por alto en la literatura. Existe teóricamente en la crítica literaria colombiana un campo denominado "Novela de la violencia" y un corpus muy bien elaborado sobre los libros literarios para niños que tocan la violencia ${ }^{4}$, pero no es de ello de lo quiero hablar. Nos interesa centralmente saber cómo las diversas formas de violencia (enumeradas en detalle ${ }^{5}$ en el Informe ;Basta ya! del Grupo de Memoria Histórica, 2013, p. 10) se instauran en la vida social y cómo la literatura narrativa de ficción elabora representaciones para darle cohesión a la experiencia de la realidad. Pero voy más allá: no me ocuparé de las novelas canónicas que tratan la génesis y desarrollo del conflicto armado en el país (El día del odio, La mala hora, Caín, Cóndores no entierran todos los días, Los ejércitos, por citar algunos ejemplos). Nos interesan, en particular, dos novelas que tocan la experiencia política del conflicto armado colombiano y cuyos destinatarios son los jóvenes: Paso a paso (1995) de Irene Vasco y Era como mi sombra (2015) de Pilar Lozano. Estas novelas se encuadran dentro de lo que se conoce como literatura juvenil.

La literatura juvenil colombiana apenas está ganando en las aulas colombianas el espacio y la recepción que se merece (Sánchez Lozano, 2013, p. 73). Si bien no hay un estudio sistemático que nos indique los hábitos de lectura en el sistema escolar ${ }^{6}$, nos parece pertinente

\footnotetext{
${ }^{4}$ Realizado por Alice Castaño y Silvia Valencia. Ver Bibliografía.

${ }^{5}$ Masacres, asesinatos selectivos, desplazamiento forzado, secuestro, toma de rehenes, desaparición forzada, violencia sexual de género, extorsión, despojo de tierras, ataque a bienes civiles, atentados terroristas, reclutamiento de menores, sevicia y tortura.

${ }^{6}$ Hay aproximaciones como las que hizo la Encuesta Nacional de Lectura en 2006. Recuperado de: http://bit.ly/1T6ww16
} 
que se posicione dentro de los maestros el valor de esa literatura y la problemática de su didáctica.

En los últimos siete años, por lo menos, los planes lectores en los colegios privados, y las dotaciones que ha hecho el Ministerio de Educación para las bibliotecas escolares en los colegios públicos (Colección Semilla) ${ }^{7}$ han dado un arraigo a la literatura infantil colombiana, que durante muchos años solo tuvo como referente central a Jairo Aníbal Niño. En esa medida es clave aprovechar esta oportunidad para empezar a vislumbrar nuevos campos para el trabajo de la literatura infantil y juvenil en el aula. Una de esas rutas tiene que ver con la lectura de libros narrativos de ficción cuyo eje temático central está relacionado con el conflicto armado colombiano.

Para los niños y jóvenes el hecho de la guerra no es ajeno, pues lo ven como noticia central en la televisión, en algunas de sus clases del área de sociales en el colegio, pero sobre todo porque algunos de ellos los sufren directamente en zonas llamadas "rojas", debido a la presencia de las guerrillas y de sus permanentes choques con la fuerza pública.

La literatura infantil y juvenil colombiana que ha tocado el tema de la violencia política, de la guerra, ha alcanzado gran nivel estético, según indican Castaño y Valencia (2014, pág. 7). Estas dos investigadoras han elaborado un corpus completo sobre esos libros. De lo que se trata en esta investigación no es repetir lo que ellas hicieron, sino, primero, valorar su pertinencia estética y, segundo, ofrecer opciones para ser trabajada esa literatura en las aulas de educación secundaria.

Lo que ha pasado políticamente, por lo menos en los últimos 50 años, hay que explicárselos a los niños y jóvenes. La brutalidad del conflicto armado (en que han estado involucrados ejércitos privados como los paramilitares, los grupos alzados en armas contra el establecimiento, las propias fuerza de seguridad del Estado como el ejército o la policía) y sus secuelas en personas reales, de carne y hueso, que han sufrido todas estas atrocidades, requiere ser recuperado a través de una Memoria que honre sobre todo a las víctimas.

La literatura puede dar la oportunidad a los niños y jóvenes de obtener no solo información, sino una forma de apropiación estética del lenguaje y su valor que pasa por revisar la memoria

\footnotetext{
${ }^{7}$ Recuperado de: http://bit.ly/1BmwIKQ
} 
de un país que tratan de entender. La literatura les puede dar arraigo verbal, ayudarles a entender problemas que no habían comprendido antes, enriquecer su imaginario y su mirada de la vida y el mundo, valorar las diferencias y ser críticos con las situaciones que los rodean. En esa medida se propone que a partir de estas dos novelas juveniles (Paso a Paso y Era como mi sombra) escritas por autoras colombianas reconocidas -seleccionadas de un corpus que el autor de esta investigación ha hecho en un barrido previo- se elabore una secuencia didáctica (SD), una modalidad de trabajo didáctico caracterizada por el desarrollo sistemático y metacognitivo de las competencias de lectura y escritura en el aula.

A diferencia de las actividades didácticas ocasionales o permanentes que se realizan en las aulas y cuyos logros pedagógicos son puntuales, la Secuencia didáctica (SD) tiene intenciones más ambiciosas: centra su preocupación en la producción de un texto escrito complejo que los estudiantes deberán trabajar y corregir al principio con el apoyo del docente, para luego concluirlo de manera autónoma. Las SD suelen ocupar entre 6 y 32 horas, esto es, un periodo académico escolar bimestral, como se le suele llamar. Como se señalará en el capítulo 4, las secuencias didácticas estimulan la capacidad autorreflexiva de los docentes, la mirada crítica sobre la propia práctica, propenden por el trabajo de docentes de grados del mismo ciclo, fomentan la investigación pedagógica situada y valoran el proceso escritural tanto de los docentes mediadores como de los estudiantes.

Esta investigación es de carácter cualitativo ${ }^{8}$. Tiene dos componentes:

a) Aprovecha herramientas de interpretación ${ }^{9}$ teórico-literaria, aplicadas a la literatura juvenil, para establecer variables consistentes que faciliten valorar dos novelas para jóvenes.

\footnotetext{
${ }^{8}$ Según Hernández Sampieri (2006), "el enfoque cualitativo puede definirse como un conjunto de prácticas interpretativas que hacen al mundo visible, lo transforman y convierten en una serie de representaciones en forma de observaciones, anotaciones, grabaciones y documentos. Es naturalista (porque estudia a los objetos y seres vivos en sus contextos o ambientes naturales) e interpretativo (pues intenta encontrar sentido a los fenómenos en términos de los significados que las personas les otorguen)". (p. 9).

${ }^{9}$ Hemos preferido el uso de la palabra "interpretación" sobre "análisis", siguiendo al profesor Wolcott (2006), quien aclara: "la interpretación no se deriva de una serie de procedimientos rigurosos, sobre los que hay un acuerdo, y que han sido cuidadosamente especificados, sino de nuestros esfuerzos por encontrar el sentido, actividad humana que incluye la intuición, la experiencia pasada, la emoción -atributos personales de los investigadores sobre los que se puede discutir indefinidamente pero no aprobarlos o desaprobarlos por unanimidad. La interpretación invita examinar, a ponderar los datos en términos de lo que significan para las personas (...). El análisis cae más en el lado científico de las cosas; la interpretación en el humanista”. (p. 38).
} 
b) Es pedagógicamente propositiva, pues incluye una propuesta de intervención didáctica que favorece la lectura de una de estas obras en las aulas con estudiantes de dos grados de educación secundaria.

Dentro del currículo de la Maestría en Estudios Literarios de la Universidad Santo Tomás esta investigación se ubica en la línea de investigación Didáctica de la literatura, modalidad de Intervención. Como lo indican los Lineamientos para la investigación (2013) de la maestría, esta modalidad:

Supone el análisis situacional de un modelo didáctico o de una práctica de enseñanza en el campo literario... y comparte algunos aspectos de la investigación teórica. Esta modalidad debe elaborar una revisión teórica del asunto y un diagnóstico detallado del caso que será objeto de intervención, de acuerdo con el modelo propuesto. (p. 29)

Por ello la investigación, de un lado, elabora una "revisión teórica del asunto" y, de otro, incluye el "análisis situacional de un modelo didáctico o de una práctica de enseñanza en el campo literario".

La investigación se ha organizado en cuatro capítulos. El capítulo 1 aborda el aspecto sociohistórico del problema (el conflicto armado) que subyace a las dos obras objeto de análisis, y también desarrolla conceptos como literatura y juvenil y competencia literaria, que facilitan dar un piso epistémico para analizar los retos que, desde mi perspectiva, enfrenta la didáctica de la literatura. En la parte final se hace una coda sobre la empatía como competencia ciudadana clave para que los estudiantes pueden tener un diálogo más asertivo con Paso a paso y Era como mi sombra. Los capítulos 2 y 3 se enfocan en analizar en detalle las obras objeto de la investigación. Se profundiza en aspectos biográficos de las autoras, en el contexto político que delimita el campo en que ellas hicieron la ficcionalización del secuestro y del reclutamiento ilegal de menores, y se ofrecen al docente lector instrumentos informativos que le facilitan comprender el valor estético y humano de estas obras. Finalmente en el capítulo 4 se presenta la propuesta de secuencia didáctica para trabajar en las aulas, preferiblemente con los grados $7^{\circ}$ y $8^{\circ}$, la novela Era como mi sombra. Lo que busca esta sección no es remplazar el trabajo de los maestros o tratarlos como robots que ejecutan órdenes pedagógicas externas, sino proporcionarles un marco de referencia que 
pueda servir para introducir desde la perspectiva currículo-didáctica-evaluación el trabajo de la literatura en las aulas.

En la parte teórico-interpretativa de las dos novelas estudiadas (capítulos 2 y 3 ) se acoge un método de interpretación ecléctico. Con ello queremos indicar, que no se excluye ningún enfoque en la interpretación de las dos obras estudiadas. Como se apreciará predomina un enfoque histórico social, pero se aprovechan conceptos provenientes del análisis estructural del relato, de la estilística, de la sociología de la literatura y de la narratología ${ }^{10}$.

En la interpretación textual de Paso a paso y de Era como mi sombra impera un método comparativo o contrastivo, que como explica Triana (2008):

...nace en el seno de la lingüística comparada. Dicha vertiente basa su análisis al tomar diferentes obras o corpus que remiten a un mismo tema y establecer tanto sus diferencias como semejanzas. Por esta razón se denomina investigación comparativa o contrastiva aquella que estudia ejemplares que pertenecen al mismo grupo, pero que se diferencian en algunos aspectos. (p. 39)

En tal sentido, esta sección teórica de la investigación tiene tres características (Triana, 2008, p. 51):

\begin{tabular}{|l|l|}
\hline Es crítica & $\begin{array}{l}\text { Analiza las características de una obra y propone variantes de } \\
\text { interpretación de los sentidos que ella encierra. Es de carácter } \\
\text { hermenéutico. }\end{array}$ \\
\hline Es histórico-cultural & $\begin{array}{l}\text { Establece relaciones causales entre el texto y su contexto histórico- } \\
\text { cultural. }\end{array}$ \\
\hline Es comparativa & $\begin{array}{l}\text { Desde un mismo enfoque teórico, contrasta por los menos dos } \\
\text { objetos de investigación como: obras, estilos, contenidos, } \\
\text { cosmovisiones. }\end{array}$ \\
\hline
\end{tabular}

En la parte de la secuencia didáctica (capítulo 4) se exponen las 13 sesiones de trabajo en clase. La secuencia tiene una duración total de 20 horas/clase sugeridas.

\footnotetext{
${ }^{10}$ En cualquier caso los aportes de estas teorías no son el centro del análisis, sino los textos-base, es decir, las novelas juveniles estudiadas. Aquellas son hipotextos. Para decirlo con Gutiérrez Girardot (2004): la teoría literaria tiene la tarea de darle "la palabra al texto", no al revés. (p. 11).
} 
En vista de que esta secuencia didáctica propone desarrollar la competencia literaria (Colomer, 1995, p. 19) con los estudiantes de $7^{\circ}$ y $8^{\circ}$ grados, se han tomado en consideración cinco aspectos que la caracterizan y luego en sesiones específicas se plantean actividades para garantizar que esos aspectos tengan visibilidad didáctica en el aula.

\begin{tabular}{|c|c|c|c|}
\hline Aspecto 1 & $\begin{array}{l}\text { Suscitar la implicación y la } \\
\text { respuestas de los lectores. }\end{array}$ & Sesión 9 & $\begin{array}{l}\text { Ficha de personaje y } \\
\text { centración en aspectos } \\
\text { locales del texto. }\end{array}$ \\
\hline Aspecto 2 & $\begin{array}{l}\text { Construir el significado de } \\
\text { manera compartida. }\end{array}$ & Sesión 7 & $\begin{array}{l}\text { Juego de roles y lectura del } \\
\text { capítulo } 1 \text { de Era como mi } \\
\text { sombra }\end{array}$ \\
\hline Aspecto 3 & $\begin{array}{l}\text { Ayudar a progresar en la } \\
\text { capacidad de hacer } \\
\text { interpretaciones más complejas. }\end{array}$ & $\begin{array}{l}\text { Sesiones } \\
11 \text { y } 12\end{array}$ & $\begin{array}{l}\text { Desarrollo de la lectura } \\
\text { crítica. Escritura de un } \\
\text { comentario }\left(1^{\mathrm{a}} \text { y } 2^{\mathrm{a}} \text { parte }\right)\end{array}$ \\
\hline Aspecto 4 & $\begin{array}{c}\text { Prever actividades que } \\
\text { favorezcan todas las } \\
\text { operaciones implicadas en la } \\
\text { lectura. }\end{array}$ & Sesión 8 & $\begin{array}{l}\text { Primera lectura de la novela. } \\
\text { Lectura cuasiespontánea }\end{array}$ \\
\hline Aspecto 5 & $\begin{array}{l}\text { Interrelacionar las actividades } \\
\text { tanto de recepción como de } \\
\text { expresión literarias, tanto en su } \\
\text { forma oral como escrita. }\end{array}$ & Sesión 13 & $\begin{array}{c}\text { Construcción de } \\
\text { competencias ciudadanas: } \\
\text { Empatía }\end{array}$ \\
\hline
\end{tabular}

La investigación operó con dos fuentes de información. La primera es un registro de consulta bibliodocumental (en Google Scholar y en el catálogo digital de la Biblioteca Luis Ángel Arango) que buscaba establecer un corpus sobre obras de literatura infantil y juvenil que ficcionalizan el conflicto armado en Colombia con base en los 13 delitos que delimita el informe ;Basta ya! (2013, p. 9). El resultado aparece en el esquema 1. Los espacios que aparecen en blanco indican que no se ha escrito una obra con ese tema. 


\section{Esquema 1}

\section{Obras de literatura infantil y juvenil asociadas a crímenes producto del conflicto armado en} Colombia

\begin{tabular}{|c|c|c|c|c|}
\hline & Acción criminal & Obra & Autor & $\begin{array}{c}\text { Fecha de } \\
\text { publicación }\end{array}$ \\
\hline 1) & Masacres & & & \\
\hline \multirow[t]{2}{*}{ 2) } & \multirow[t]{2}{*}{ Asesinatos selectivos } & El gato y la madeja perdida & Francisco Montaña & 2013 \\
\hline & & Los agujeros negros & Yolanda Reyes & $2000 ; 2008$ \\
\hline \multirow[t]{2}{*}{ 3) } & \multirow[t]{2}{*}{ Desplazamiento forzado } & La luna en los almendros & Gerardo Meneses & 2011 \\
\hline & & El mordisco de la medianoche & Francisco Leal Q. & 2009 \\
\hline 4) & Secuestro y toma de rehenes & Paso a paso & Irene Vasco & 1995 \\
\hline 5) & Desaparición forzada & Camino a casa & Buitrago - Yockteng & 2008 \\
\hline 6) & Sevicia y tortura & & & \\
\hline 7) & Violencia sexual de género & & & \\
\hline 8) & $\begin{array}{l}\text { Despojo de tierras y } \\
\text { extorsiones }\end{array}$ & Mapaná & Sergio Álvarez & 2006 \\
\hline 9) & Ataque a bienes civiles & & & \\
\hline 10) & Atentados terroristas & & & \\
\hline 11) & Reclutamiento de menores & Era como mi sombra & Pilar Lozano & 2015 \\
\hline 12) & Acciones bélicas & El árbol triste & Triunfo Arciniegas & 2008 \\
\hline 13) & Minas antipersonal & & & \\
\hline
\end{tabular}

Nota: Elaboración propia.

Finalmente se seleccionaron dos novelas juveniles. Paso a paso (1995) de Irene Vasco y Era como mi sombra (2015), de Pilar Lozano, porque tienen personajes protagónicos que están en las antípodas de la pirámide de las clases sociales en Colombia y de este modo nos ayudan a hacer un análisis comparativo sobre los recursos literarios que cada obra utiliza en la ficcionalización del secuestro y del reclutamiento ilícito de menores, respectivamente.

La segunda fuente de información que se aprovechó fue una entrevista semiestructurada dirigida a las autoras de las obras seleccionadas, con el fin de conocer la genealogía, los procedimientos, y la autopercepción de los logros alcanzados en la escritura de estas novelas. Básicamente hubo un encuentro presencial, acompañado de un buen café ${ }^{11}$. Las autoras prefirieron el registro del diálogo informal en lugar de dar respuesta puntual a las preguntas

11 En la red social Facebook, dejé el registro del encuentro con Irene Vasco. Recuperado de: http://on.fb.me/1Ulb2N1 
enviadas antes por correo electrónico (ver Anexo 2). En ningún caso se hizo ninguna sistematización de las respuestas, pues lo que nos interesaba era dar visibilidad a la autora, a su capacidad autocrítica, y complementar información general que pudiera ser de utilidad para el el autor de esta investigación.

Se espera que esta investigación sea leída por docentes que quieren involucrar la lectura de novelas juveniles en las aulas de educación secundaria y generar cambios en las prácticas de enseñanza de la literatura: cambios en los docentes en cuanto a su percepción de la literatura infantil y juvenil colombiana, y cambios en los estudiantes con respecto al valor de la literatura en sus vidas, en su formación humanística y en la construcción de la Memoria social y política de Colombia en los últimos 50 años. 


\section{Capítulo 1}

CONFLICTO ARMADO, NOVELA JUVENIL Y COMPETENCIA LITERARIA 


\section{El CONFLICTO ARMADO EN COLOMBIA}

El concepto "conflicto armado" es un eufemismo para designar la guerra que tuvo su origen en la exclusión política que inauguró el Frente Nacional, en 1957, ese interesado pacto entre las élites del partido liberal y el conservador, las cuales se repartieron el manejo del país durante 16 años (1958-1974).

\section{Imagen 1. Firma del Frente Nacional liberal-conservador}

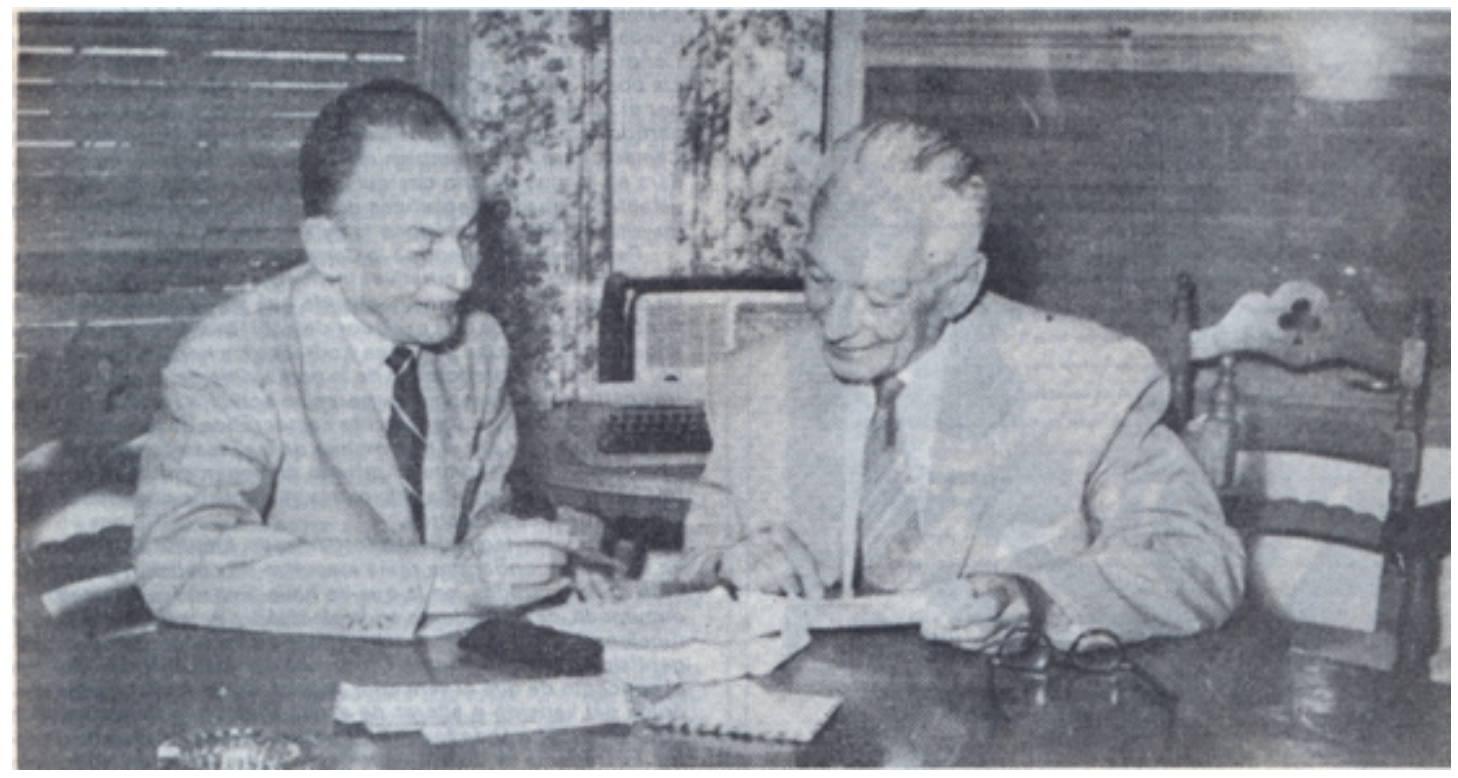

Nota: El liberal Alberto Lleras Camargo y el conservador Laureano Gómez firman el acuerdo que crea el Frente Nacional, en Sitges, España, en 1957. En: Castilla, J. H. (abril 1989). El Frente Nacional: el sagrado derecho a la continuidad. En: Investigar, 2, 41-49.

Algunos historiadores difieren de esa idea. Wills (2015) o Giraldo Ramírez (2015) remiten el inicio del conflicto armado a comienzos de los años 20, con el enfrentamiento feroz por la posesión de la tierra y las peticiones de una reforma agraria, que tímidamente se propuso durante el primer gobierno progresista de López Pumarejo (1930-1934), pero que en verdad siempre fue boicoteada por los grandes hacendados. Otros, como Molano Bravo (2015), lo ubican en la Violencia de los años 40, por razones de sectarismo político, y cuando tuvo su momento más dramático con el asesinato del líder liberal Jorge Eliécer Gaitán y la dictadura civil de Laureano Gómez (1950-1953). Los politólogos más jóvenes (Duncan, 2015; Gutiérrez Sanín, 2015) consideran que la fase fuerte del conflicto armado comenzó con la fundación de las guerrillas de izquierda de las Farc (1964), del Eln (1966) y del Epl (1967). 
Todos están de acuerdo en que el conflicto armado alcanzó dimensiones desproporcionadas cuando las Farc se revitalizaron gracias al negocio del narcotráfico a mediados de 1980 y en respuesta se formaron grupos paramilitares de derecha en los 90 para combatirlos.

En Contribuciones al entendimiento del conflicto armado en Colombia (2015), escritos por 14 reconocidos académicos, queda claro que el conflicto no fue causado exclusivamente por las Farc "hace 50 años", según la simplificación de un expresidente de la república, sino que tiene un origen multicausal:

Como en otras épocas, las tramas son confusas: las motivaciones privadas se entrecruzan con las políticas, las humillaciones personales o la codicia con los reclamos de justicia, en una guerra que sigue siendo, no obstante estas imbricaciones, de carácter nacional y de naturaleza políticas. (Wills, 2015, p. 814).

Esta guerra no ha sido "convencional" entre ejércitos claramente diferenciados y que combaten en campos abiertos por ideales patrióticos. Ha contado y ha sido azuzada por actores con intereses políticos y económicos particulares. Guerrilleros, paramilitares, oficiales, suboficiales y soldados de las Fuerzas Armadas han estado vinculados de diferentes modos. Pero también políticos y empresarios en la legalidad que con dineros públicos o privados apoyaron a las fuerzas derechistas de paramilitares. Varios llegaron al Congreso como senadores o representantes, cuando no cooptaron alcaldías, concejos municipales y asambleas de diputados, que robaron a su antojo.

La principal damnificada, según Pécaut (2000, p. 15) ha sido la población civil. Las víctimas ${ }^{12}$ están entre el "pueblo", y muchos de los delitos cometidos contra él fueron ejecutados precisamente por los grupos guerrilleros, que tenían entre sus eslóganes defenderlo. Los que más han sufridos los desmanes y brutalidades de la guerra han sido en particular campesinos aparceros, comunidades indígenas o afrodescendientes (GMH, 2013, p. 25), los más pobres entre los pobres.

\footnotetext{
${ }^{12}$ Víctima es "toda persona que haya sufrido daños, individual o colectivamente, incluidas lesiones físicas o mentales, sufrimiento emocional, pérdidas económicas o menoscabo sustancial de sus derechos fundamentales, como consecuencia de acciones u omisiones que constituyan una violación manifiesta de las normas internacionales de derechos humanos o una violación grave del derecho internacional humanitario". (Torrijos, 2015, p. 712).
} 
Las cifras de muertos a causa del conflicto armado varían, pero según el Grupo de Memoria Histórica, pueden ser 220.000 entre los años 1958 y 2012. Todos los actores del conflicto armado han demostrado una capacidad arrasadora y cínica para matar, destruir, secuestrar, expropiar, violar.

En Colombia, el conflicto armado no tiene una modalidad de violencia distintiva. Los actores armados enfrentados han usado y conjugado todas las modalidades de violencia. Todos han desplegado diversas modalidades y cometido crímenes de guerra y de lesa humanidad, haciendo a la población civil la principal víctima del conflicto. (GMH, 2013, p. 20).

Gutiérrez Sanín (2015, p. 556) resume las cifras escalofriantes de los delitos asociados a la guerra (ver cuadro 1):

Cuadro 1. Delitos cometidos por los actores del conflicto armado. Corte a septiembre de 2014

\begin{tabular}{|l|c|}
\hline \multicolumn{1}{|c|}{ Hecho } & Personas \\
\hline Desaparición forzada & 152.455 \\
\hline Desplazamiento & 6.044 .151 \\
\hline Homicidio & 931.720 \\
\hline $\begin{array}{l}\text { Minas antipersonal/Munición sin explotar/ } \\
\text { Artefacto explosivo }\end{array}$ & 11.777 \\
\hline Perdida de bienes muebles o inmuebles & 88.567 \\
\hline Secuestro & 37.464 \\
\hline Vinculación de niños, niñas y adolescentes & 7.722 \\
\hline
\end{tabular}

Nota: Adaptación del cuadro realizado por Gutiérrez Sanín (2015). ¿Una historia simple? En: Contribución al entendimiento del conflicto armado en Colombia. (pp. 521-563). Bogotá: Desde Abajo.

El reparto de la actividad criminal varía: los grupos guerrilleros han secuestrado más, además de reclutar más los niños para la guerra; los paramilitares son responsables del mayor número de muertos en cerca de 1.982 masacres (GMH, 2013, p. 36) y del desplazamiento forzado de 
comunidades enteras; también los paramilitares, en alianza con notarios corruptos se apropiaron de las tierras, animales y cultivos de los desplazados y en acuerdos con políticos locales en algunas regiones del país se robaron el erario y regalías; el Ejército y los servicios secretos del Estado están altamente comprometidos en la desaparición forzada de personas, la mayoría sindicalistas, defensores de derechos humanos o líderes populares ${ }^{13}$, y en los espantosos e inhumanos "falsos positivos".

La capacidad de crueldad y de inhumanidad de los actores armados se renovó con los años, sobre todo a partir de los años 90 del siglo pasado. No solo se mataba, sino se "remataba y se contramataba" (al decir de la profesora María Teresa Uribe). La tortura se sofisticó. No solo se mutilaba en vida un cuerpo de un "informante", sino que después se le daba un tiro de gracia y se le desmembraba. Se le lanzaba a un río, o para no dejar huella, se incineraba en hornos crematorios. Los muchachos soldados "retenidos" por las Farc en tomas en pueblos lejanos llegaron a estar sin libertad durante 13 años (¡13 años!). Una excandidata a la presidencia resistió 7 años de secuestro. Centenares de familias siguen a la espera de saber si los huesos de un cadáver descubierto como NN en un cementerio (o a algún camino veredal) es el padre o el hijo desaparecido. Una mujer humilde, delante de sus hijos y sus padres, fue violada por 40 paramilitares. Como lo ha dicho Wills: "Escucho los testimonios de las víctimas y descubro a través de sus voces que, en mi país, la sevicia y la ferocidad han traspasado los límites de lo que yo era capaz de imaginar" $(2014)^{14}$.

\footnotetext{
13 “Así, los paramilitares estructuraron e implementaron un repertorio de violencia basado en los asesinatos selectivos, las masacres, las desapariciones forzadas, las torturas y la sevicia, las amenazas, los desplazamientos forzados masivos, los bloqueos económicos y la violencia sexual. Las guerrillas recurrieron a los secuestros, los asesinatos selectivos, los ataques contra bienes civiles, el pillaje, los atentados terroristas, las amenazas, el reclutamiento ilícito y el desplazamiento forzado selectivo. Además afectaron a la población civil como efecto colateral de los ataques a los centros urbanos, y de la siembra masiva e indiscriminada de minas antipersonal. La violencia de los miembros de la Fuerza Pública se centró en las detenciones arbitrarias, las torturas, los asesinatos selectivos y las desapariciones forzadas, así como en los daños colaterales producto de los bombardeos, y del uso desmedido y desproporcionado de la fuerza. La violencia contra la integridad física es el rasgo distintivo de la violencia paramilitar, mientras que la violencia contra la libertad y los bienes define la violencia guerrillera. En otras palabras, los paramilitares asesinan más que las guerrillas, mientras que los guerrilleros secuestran más y causan mucha más destrucción que los paramilitares”. (GMH, 2013, p. 35).

${ }^{14}$ Recuperado de: http://bit.ly/1TADLxP
} 
Imagen 2. Las huellas del dolor dejadas por el conflicto armado

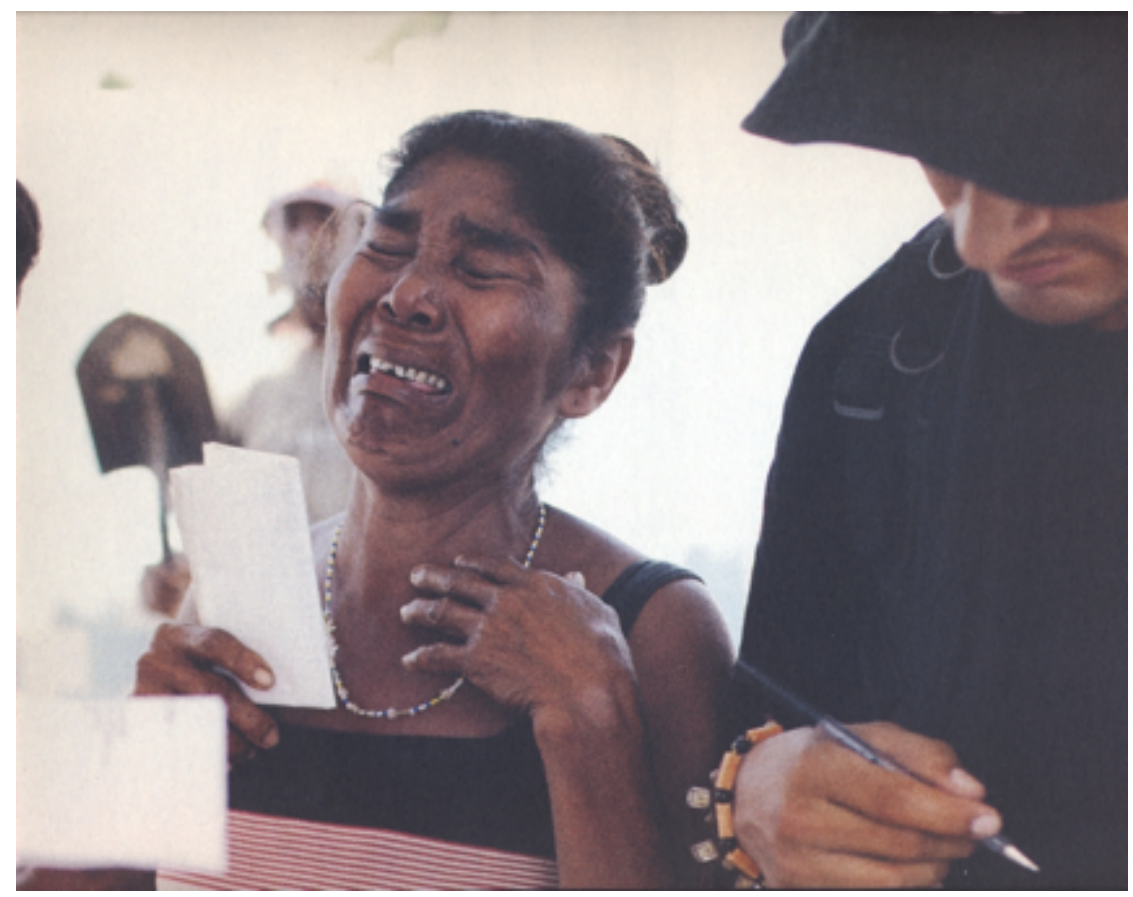

Nota: La señora Teresa Meléndez reconoce una prenda de su esposo asesinado en San Onofre por paramilitares, dirigido, por alias "Cadena". Tomada de Ferry, S. (2012). Violentología: un manual del conflicto colombiano. Bogotá: Ícono Editores.

La guerra se focalizó en zonas campesinas donde la guerrilla había ganado territorios y los paramilitares llegaron a desalojarlos. Giraldo Ramírez (2015, p. 503) en su informe a la Comisión Histórica del Conflicto y sus Víctimas (CHCV) dice que el departamento de Antioquia sufrió el mayor número de crímenes asociados al conflicto armado (ver cuadro 2), pero también hay que recordar que humildes pueblos fueron una y otra vez objeto de masacres, desplazamiento forzado, reclutamiento de menores. Pueblos que quedaron estigmatizados para siempre por los hechos terribles que allí sucedieron: El Salado, Trujillo, Mapiripán, La Rochela, Bojayá, San Carlos, El Aro. 


\section{Cuadro 2. Participación de víctimas del conflicto armado por departamento}

\begin{tabular}{|l|c|c|c|c|c|}
\hline Muertos en & Antioquia & Santander & Norte & Cauca & Cesar \\
masacres & $30 \%$ & $7,2 \%$ & $6,4 \%$ & $5,9 \%$ & $5,8 \%$ \\
\hline Asesinato & Antioquia & Santander & Norte & Cesar & Bolívar \\
selectivo & $22,8 \%$ & $8,9 \%$ & $7,6 \%$ & $5,8 \%$ & $5,3 \%$ \\
\hline Victimas & Antioquia & Meta $9,8 \%$ & Caquetá & Norte & Nariño \\
minas & $22,2 \%$ & & $7,7 \%$ & $7,1 \%$ & $6,7 \%$ \\
\hline Secuestro & Antioquia & Valle $7,3 \%$ & Cesar & Bogotá & $\begin{array}{c}\text { Santander } \\
\end{array}$ \\
\hline Desplazados & Antioquia & Bolivar & Magdalena & Chocó & Nariño \\
& $19,2 \%$ & $8,3 \%$ & $7,6 \%$ & $5,4 \%$ & $5,3 \%$ \\
\hline Combates & Antioquia & Santander & Norte & Cauca & Meta \\
& $21,8 \%$ & $6,9 \%$ & $6,2 \%$ & $5,5 \%$ & $5,1 \%$ \\
\hline
\end{tabular}

Nota: Adaptación a partir de los datos aportados por Giraldo Ramírez, J. (2015). Política y guerra sin compasión. Contribución al entendimiento del conflicto armado en Colombia. (pp. 471-519). Bogotá: Desde Abajo.

Paradójicamente el conflicto armado no ha tocado -salvo casos puntuales ${ }^{15}$ - a las grandes ciudades (Bogotá, Cali, Cartagena). Las huellas del conflicto son percibidas como "lunares" que afectan el paisaje urbano: la niña indígena desplazada que pide limosna en un puente peatonal; el vendedor de dulces que a la fuerza entra a un bus de Transmilenio con la esperanza de que le compren; la joven desplazada que trata de ubicarse en el servicio doméstico para sostener a su familia. La guerra, como acertadamente lo ha señalado Álvaro Sierra $\left(2015\right.$, p. 19) ${ }^{16}$ ha sido un tema de la Colombia rural, no de la Colombia urbana. Esta última ha vivido en un periodo de inconsciencia colectiva. La guerra ha sido un tema de "otros". A ello han contribuido algunos medios de comunicación masiva que trivializaron la información ("otro secuestro, otra masacre, la gente ya no aguanta más violencia”) o la pusieron en el espectro de la polarización: "Estos son buenos; estos son malos. Lo que se haga por acabar con los 'malos' está bien”.

\footnotetext{
${ }^{15}$ Uno de ellos el atentado al Club el Nogal, en Bogotá, en 2003, que dejó 36 personas fallecidas y más de 200 heridos. Por el crimen tendrán que responder los comandantes de las Farc, pues los autores materiales ya están muertos.

${ }^{16}$ Recuperado de: http://bit.ly/10814cM
} 
Las consecuencias del conflicto armado son devastadoras (¡tener 6 millones de desplazados, para empezar!). Millones de personas con la vida destruida y con un futuro poco claro. Por lo menos se necesitarán 5 años para empezar a aclarar qué pasó (un Tribunal de Paz tendrá esa tarea) y empezar a ver los efectos de la reparación (si alcanza el dinero para la reparación). La polarización aún persiste (basta ver los titulares de los periódicos), el "yo tengo la razón, usted no" y la idea de que al que piensa diferente, hay que eliminarlo (intelectual o físicamente). El mundo campesino está roto: los lazos de cohesión social y de arraigo a la tierra en crisis. Niños sin padre, hombres o mujeres con problemas psicológicos agudos, persistencia de la pobreza y la exclusión ${ }^{17}$. Colombia después de más de seis décadas de conflicto armado queda parcialmente destruida, fragmentada. Su recomposición dependerá en mucho de lo que cada persona haga para resarcir el daño que los victimarios infligieron.

Quienes somos maestros de lenguaje y amamos la literatura, y valoramos su poder persuasivo, estamos en la tarea de ayudar en esa reconstrucción, al menos desde la perspectiva intelectual. Es evidente que ha surgido una nueva literatura que toca el conflicto armado y que es necesario organizar un corpus para hacer un balance objetivo.

En cuanto compete al autor de esta investigación, su aporte está en discernir de qué modo la narrativa literaria para jóvenes da cuenta de dos de los delitos más atroces asociados al conflicto armado: el secuestro y el reclutamiento de niños para la guerra.

\section{LA “NOVELA JUVENIL" COMO GÉNERO LITERARIO}

"Novela juvenil" es un concepto en construcción, que todavía la teoría literaria no ha aceptado formalmente, y que proviene del ámbito editorial (Díaz Plaja, 2009). Tiene su origen en una categorización que hizo -ya hace más de veinte años- la profesora de la Universidad de Murcia, Carmen Bravo Villasante, en un clásico académico sobre la LIJ ${ }^{18}$ : Ensayos de literatura infantil (1989). Allí advertía que estaba surgiendo en el ámbito europeo una nueva literatura, atrevida, dirigida esencialmente a los jóvenes, de corte realista, y que en España brillaba por su ausencia:

\footnotetext{
${ }^{17}$ En ello estamos de acuerdo con Ramírez Orozco (2013): "Es necesario formular estrategias de paz que modifiquen las causas estructurales del conflicto armado". (p. 30).

${ }^{18}$ Abreviatura para literatura infantil y juvenil.
} 
La nueva problemática juvenil, que surge con los nuevos cambios sociales, marca una corriente en la novelística actual, de gran interés, y que no siempre es apta para todos los países, ya que ofrece conflictos circunscritos a su propio ambiente. De todos modos, se hace notar una corriente común que es la historia del joven o la joven inadaptada, en choque con la sociedad de su tiempo y con la generación precedente. Se plantean problemas sociales, de lucha de clases, de política, de discriminación, de drogas, de homosexualismo. (p. 82)

Es comprensible que la España posfranquista -todavía mojigata, pero sobre todo editorialmente desorientada- no aceptara esa clase de literatura, hasta que editoriales como Alfaguara y Ediciones SM se arriesgaron e introdujeron colecciones similares a finales de los años 70 del siglo pasado, con títulos generalmente traducidos del alemán, del inglés o del francés.

La aceptación de estos libros para jóvenes, en el entorno del educación secundaria, fue inmediata y creció enormemente en los años 80. Eran libros que la crítica literaria formal desconoció porque la calidad literaria quedaba opacada a menudo ante historias que se centraban típicamente en los problemas adolescentes: abandono, violencia doméstica, anorexia, alcoholismo, guerras, migración, xenofobia, fracaso escolar, suicidio, intolerancia, etc. (Silva Díaz, 2009, p. 189).

El fenómeno editorialmente creció, pero no su reflexión. En un interesante estudio, la profesora Carmen Elisa Acosta (2011), de la Universidad Nacional de Bogotá, ha acotado que los problemas epistémicos que trajo consigo esta literatura -que en adelante, a falta de mejor mote, se denominó “juvenil”- impidieron -al menos en Colombia- un estudio juicioso, pues los problemas de este objeto de estudio se escapaban al marco de una teoría críticoliteraria tradicional ${ }^{19}$. Para comenzar: ¿qué es un autor de literatura juvenil?, ¿por qué y para quién escribe? ¿En que se diferencia de un autor de literatura "para adultos”? Además, ¿mediante qué reglas -si las hay- se introduce en el mercado de los libros?, ¿hasta dónde los editores intervienen en la producción creativa de estos libros?

\footnotetext{
${ }^{19}$ Parafraseo acá apartes de una reseña que escribí sobre el libro de Pensar la literatura infantil. Interpretación a varias voces. La reseña se puede leer en línea. Recuperado de: http://bit.ly/1KMHMHd
} 
La cuestión de los géneros no era un problema menor: ¿novela, poesía, álbumes, teatro, cuento? ¿Deben ser evaluados con el mismo rasero que la gran literatura? Y además, ¿qué hacer con el asunto de la historización de esta literatura? ¿Y qué categorización darles a los mediadores que intervenían en su circulación?

En el centro del problema estaba en que esta literatura surgía en un entorno particular, ajeno al ámbito de la circulación de la literatura tradicional para adultos y planteaba retos para el intérprete que pasaban por valorar la relación entre literatura, escuela y mercado (esquema 2).

\section{Esquema 2. Entorno de la literatura juvenil}

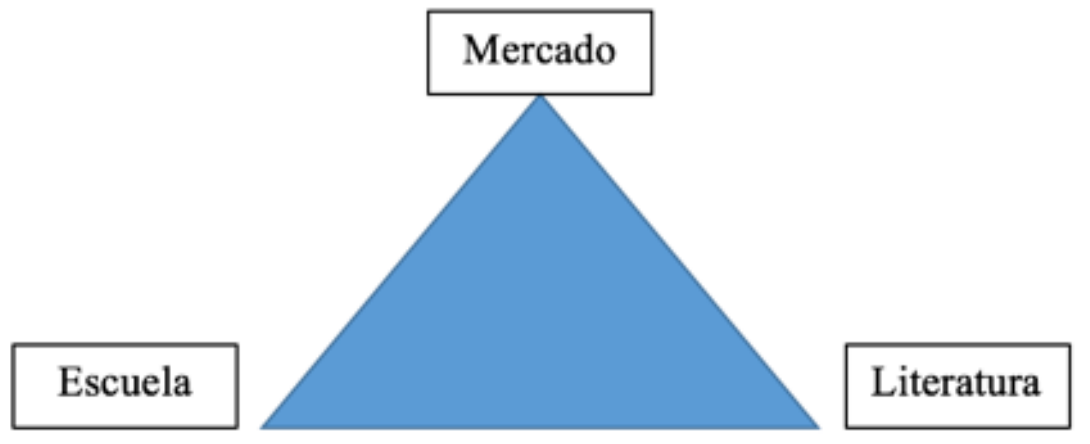

Nota: Elaboración propia.

En efecto la literatura juvenil (y dentro de ella, la novela juvenil) surgía como propuesta de las editoriales comerciales frente a un target de mercado no explorado antes: los jóvenes. ¿Pero qué es un joven? Colomer (2009) señala que la adolescencia “es la representación moderna de una etapa de vida formada a partir de la prolongación de los estudios secundarios a toda la población y del retraso de la independencia familiar y social” (p. 5). Silva Díaz (2009) agrega citando a la sicoanalista María Cristina Ortega:

El adolescente se plantea su ubicación en el mundo y para ello debe abandonar la dependencia e indefensión infantil, y lograr una relativa autosuficiencia adulta, a través de la búsqueda de una identidad propia. Como todo ser humano, necesita encontrar sentido a su propia existencia. La capacidad de pensar sobre sí mismo y sobre el mundo es una adquisición de la adolescencia, una ampliación de la conciencia moral que se produce cuando se resuelve el complejo de Edipo (p. 186) 
Para las editoriales colombianas en 1990 era claro que ser joven, significaba estar en algún grado de educación secundaria más arriba de grado $7^{\circ}$. Desde luego que esta idea de joven, como mercado, tenía su sentido en una nueva demanda de productos educativos a la que no todos tenían acceso en esos años. Muchos jóvenes de colegios públicos debían seguir leyendo los "clásicos" (en ediciones terribles) o "resúmenes" (en esa época no existía internet y su Rincón del vago) en fotocopias. Y de otro lado (como nos lo muestra de manera dramática Pilar Lozano en Era como sombra) otros jóvenes, la mayoría campesinos, afrodescendientes o indígenas de las zonas más pobres del país, eran reclutados como soldados por los grupos armados irregulares: guerrilla y paramilitares.

El mercado de las novelas juveniles cambió definitivamente con un libro que no surgió para el mercado de prescripción (el escolar). Fue el mercado de lo que editorialmente se llama “sagas”. La primera de ellas, proveniente del ámbito anglosajón, fue Harry Potter, en 1997. Uno tras otro los 7 tomos aparecieron hasta 2008 y abrieron un nuevo mercado de literatura para los adolescentes (fundamentalmente ellos eran los destinatarios principales) que pasaba por encima de lo que los mediadores (los profesores) consideraban como literatura aceptable. Se consolidaba, entonces, una literatura sin mediadores, una literatura de pares, que circulaba a través de librerías (físicas y virtuales) y era recomendada boca-oreja gracias a los muchachos. Con la fuerte entrada de internet y de las redes sociales, este mercado explotó y creció exponencialmente ${ }^{20}$. Una saga de 3 tomos - cada uno de 800 páginas- como Memorias de Idhún (2004) de Laura Gallego, vendió 1 millón de ejemplares en España. Crepúsculo una tetralogía de vampiros, de Stephenie Meyer, pudo vender cerca de 100 millones de ejemplares en el mundo, en 37 lenguas, sobre todo entre chicas de 13 a 17 años $^{21}$. Se imponía entonces la que se ha conocido en ámbitos crítico-literarios como "literatura de fórmula" o "literatura de marketing".

Este apocalipsis era aparente. Desde 2005, por los menos, simplemente se reorganizó el mercado "literatura juvenil" y hubo espacios para diversas propuestas editoriales tanto para

\footnotetext{
${ }^{20}$ La profesora de la Universidad de Valencia Gemma Lluch ha explicado este fenómeno en su ensayo "Las nuevas lecturas deslocalizadas de la escuela" (cfs. Lluch, 2010, p. 105-128).

${ }^{21}$ Las cifras son aproximadas y es posible que las ventas sean mayores, según la revista estadounidense experta en temas editoriales Publisher Weekly: http://bit.ly/1KyIU72
} 
el escenario escolar, como para el extraescolar. Díaz Plaja (2009, p. 126-147) ha realizado una clasificación minuciosa (esquema 3) que merece una lectura detallada.

\section{Esquema 3. Clasificación de las lecturas juveniles}

\begin{tabular}{|l|l|}
\hline \multicolumn{1}{|c|}{ Alta cultura } & \multicolumn{1}{c|}{ Baja cultura } \\
\hline Clásicos de las literaturas nacionales & Best sellers (sagas) \\
\hline Clásicos universales & Cómic y novela gráfica \\
\hline Bildungsroman (novela de formación) & Fanfic \\
\hline Literatura juvenil homologada & Relato multimedia \\
\hline
\end{tabular}

Nota: Adaptado de Díaz Plaja (2009). Entre libros: la construcción de un itinerario lector propio en la adolescencia. En: Colomer, T. (Coord.). Lecturas adolescentes (pp. 119 - 150). Barcelona: Graó.

Nos interesa destacar la literatura juvenil homologada ${ }^{22}$, en especial, el género novela juvenil realista, pues las dos obras colombianas que hemos trabajado en esta investigación, se encuentran en ese renglón ${ }^{23}$.

Sobre el realismo en la literatura juvenil Silva Díaz (2009) aclara:

la narración realista ocupa lugar privilegiado dentro de la literatura juvenil. Las obras que se agrupan bajo categorías como "psicoliteratura", o "novela sobre problemas", o bajo tendencias artísticas como "realismo crítico", sin duda son las que mejor encajan en la definición que los manuales ofrecen sobre la literatura juvenil: narraciones escritas para o sobre los jóvenes que reflejen los temas y conflictos que afectan a los adolescentes. (p. 188)

Paso paso (1995), de Irene Vasco y Era como mi sombra, de Pilar Lozano son dos novelas realistas juveniles muy logradas, en nuestra opinión, y así lo hemos tratado de probar en los

\footnotetext{
${ }^{22}$ Se le denomina así a "las narraciones escritas y publicadas en los últimos 25 o 30 años y que tienen como destinatario específico a los lectores adolescentes”. (Díaz Plaja, 2009, p. 132).

${ }^{23}$ No sobra decir que todas las novelas juveniles que tocan el conflicto armado en Colombia se ubican en el realismo. Aparte de las dos que hemos trabajado en este investigación, también son realistas El gato y la madeja perdida (2013) de Francisco Montaña. También de él No comas renacuajos (2008) y la estremecedora La muda (2010). Además Mambrú perdió la guerra (2012), de Irene Vasco; Los agujeros negros (2000, 2008), de Yolanda Reyes; El mordisco de la medianoche (2009), de Francisco Leal Quevedo; La luna en los almendros (2011) de Gerardo Meneses y Mapaná (2006) de Sergio Álvarez.
} 
dos extensos capítulos que le hemos dedicado (ver p. 76-149). El trabajo de mímesis, de representación de la realidad ${ }^{24}$, que han hecho las convierte en obras compactas y de gran nivel estético-literario. Estamos seguros de que tanto los mediadores como los destinatarios finales de estas obras (los jóvenes en edad colegial) encontrarán en estas novelas un recurso para comprender, desde una perspectiva literaria, los hechos históricos que hemos vivido en las últimas décadas, relacionados con la guerra, el conflicto armado en Colombia.

Los aspectos más destacados, a nuestro parecer, de las dos novelas son:

1) Usan un narrador en primera persona que busca generar empatía (un habla de tú a tú) con el joven lector.

2) Se basan en hechos verdaderos, pero los transforman literariamente. Paso a paso se basa en la historia de una familia caleña, cuyo padre fue secuestrado a finales de los años 80; Era como mi sombra en los relatos que niños desvinculados del conflicto le contaron a Pilar Lozano y que ella recogió en su libro de crónicas periodísticas Crecimos en la guerra (2014).

3) Son novelas de estructura convencional que no acuden a un experimentalismo narrativo innecesario.

4) Se cuidan de no ceder al melodrama o al relato "llorón" manipulador.

5) Son obras críticas de corte testimonial, pero que no caen en el panfleto ni en la denuncia gratuita o señaladora.

6) Siguen el modelo de realismo crítico, que Ángel Rama (2006) caracterizó como síntoma de la narrativa del postboom, es decir, que desbordan las intenciones del realismo social tipo Zola y se enfocan en criticar de forma mediada la sociedad a la cual retratan y busca desentrañar.

7) Las intenciones de las obras son testimoniales: mostrar las secuelas del secuestro en una familia (en Paso a Paso) y describir las condiciones sociales en que un niño campesino acaba en la guerrilla (Era como mi sombra).

8) Juntas son novelas que siguen las reglas de organización narrativa y de tensión dramática provenientes de la novela francesa (Balzac, Stendhal, Flaubert).

9) Acuden sin complejos a tocar las emociones del lector.

\footnotetext{
${ }^{24}$ Para seguir el título de la obra monumental de Eric Auerbach $(1952 ; 2014)$.
} 
10) Se apoyan en los saberes del "lector implícito",25, esto es, que los lectores son jóvenes con conocimientos (así estos sean limitados) que aportan a la construcción de significado y a la interpretación activa, contextualizada, de la obra.

11) Los personajes protagónicos son sólidos y representan muy bien la escalera social que está en los orígenes del conflicto armado en Colombia. Patricia (Paso a paso) es de origen burgués; el niño guerrillero (Era como mi sombra), representa al país profundo, olvidado, excluido. Juntos son héroes problemáticos en el sentido lukacsiano porque generan tensiones, contradicciones y transformaciones que se perciben a lo largo de la novela.

12) Son reservadas en el manejo de las escenas de violencia. En general acuden a la elipsis para narrar el secuestro, el homicidio, la toma armada de municipios, etc. El "lector implícito" debe agregar la información que falta.

13) Juntas novelas cumplen el requisito de las buenas obras que estableció en su particular mímesis Vargas Llosa (1999, 2014): consolidan realidad autónomas, que si bien se basan en la realidad real, crean un mundo particular ficcionalizado, que arrastra a los lectores.

14) Detrás de las dos obras hubo buenas editoras que cumplieron su papel de acompañar a las autoras en el proceso de gestación de las obras y preparar el manuscrito para su publicación: Margarita Valencia (para Paso a paso) y María Fernanda Paz-Castillo (para Era como mi sombra).

15) En las dos novelas aparecen ritos religiosos católicos. La religión cumple el papel de dar esperanza a los personajes en medio del agobio por la tragedia que viven.

16) Demuestran que además de buenas novelistas, son intelectuales contestatarias al poder (en la denominación de Ángel Rama). Con sus obras se ubican al lado de lo vivido por las víctimas, no de los victimarios (que apenas si aparecen retratados). Su postura ética como escritoras se resume en un principio: no callar. Contra el olvido, contra la dispersión, contra la indiferencia, contra el poder, ellas oponen la memoria. La memoria de las víctimas.

\footnotetext{
${ }^{25}$ Según el Diccionario de análisis del discurso (2005), la noción de lector implícito "permite reconstruir la representación que el autor de un texto debió hacerse de su lector: alguien dotado de determinado saber enciclopédico, de determinada aptitudes lingüísticas (léxicas, textuales, etc.), de determinada competencia comunicativa para interpretar el texto. (p. 347).
} 
Los adolescentes como lectores son particulares (Petit, 1999; Sarland, 2003; Chambers, 2008) y unificarlos o darles identidad homogénea resulta ingenuo. Pero sí sabemos, como lo he escrito en otra parte, que "leen con el corazón", es decir, que hacen lecturas subjetivas:

Cada joven es un lector único y resemantiza de un modo personal lo que lee. Los jóvenes no son "lectores críticos", objetivos, pues lo que buscan en los libros es un "yo" sincero que les hable a "ellos" como sujetos exclusivos. (Sánchez Lozano, 2004, p. 68) ${ }^{26}$.

Estas dos novelas juveniles, Paso a paso y Era como sombra, pueden ayudar a los adolescentes a entrar en el mundo adulto -en los problemas que enfrentamos los adultos-, a crecer intelectualmente, y a entender de modo inteligente y poético una realidad que ha sido manipulada (o fragmentada) por los medios de comunicación masiva.

Y el lugar ideal para leer esas obras es la escuela. Como lo ha señalado Manresa (2009), la institución escolar tiene que estar comprometida con la "ampliación del bagaje lector" de los muchachos o de lo contrario quedarán en manos del mercado, de la manipulación virtual, y del gusto chato que caracteriza a algunos mediadores.

Proponerse crear o aumentar los hábitos lectores desde la escuela no puede basarse en generalidades; es imprescindible diseñar estrategias que cubran cada una de las características necesarias para ser un buen lector. Y la investigación muestra los efectos positivos de estas estrategias. La inmersión en un entorno poblado de textos propicia el aumento del apetito lector, lo cual se traduce en una ampliación de los horizontes de lectura y, en consecuencia, en un avance de su formación lectora y literaria. (p. 49).

\section{EL LUGAR DE LA LITERATURA EN EL CURRÍCULO: LA COMPETENCIA LITERARIA}

Los principales aportes sobre el concepto "competencia literaria" los ha hecho la profesora Teresa Colomer (Universidad Autónoma de Barcelona), que en gran parte, como ella reconoce, provienen de la literatura académica anglosajona de los años 80 del siglo pasado

\footnotetext{
${ }^{26}$ Recuperado de: http://bit.ly/1Q13nhI
} 
(cfs. 1995, p. 17) ${ }^{27}$. Su libro Andar entre libros (2005), en especial el capítulo 1, "Leer en la escuela", será clave en establecer esa ruta.

La "competencia literaria" es la respuesta de un conjunto de teóricos de la lectura que la propusieron como alternativa a la "enseñanza de la historia literaria" en educación secundaria, un modelo que ya desde los años 1980 se percibía como agotado, pues basaba su fuerza en en una vulgarización de los análisis formalistas de la teoría literaria y, de otro, se sostenía en la presión de obligar a los estudiantes a leer los “clásicos”. Desde esta perspectiva, el objetivo de la educación literaria, sobre todo en secundaria, debería cambiar, pues la tarea no era llenar a los muchachos de información parcelada -asignificativa- de autores, obras, fechas, argumentos de las obras, corrientes literarias, etc., sino propiciar-como dice Roudell (1996, citado por Colomer, 2014)- la adquisición progresiva de un "saber literario", es decir, la construcción de conductas lectoras trasladables fuera del contexto en el que han sido adquiridas" (p. 112).

Para Colomer, entonces, la competencia literaria supone dos características (ver esquema 4).

\section{Esquema 4. Definición de competencia literaria}

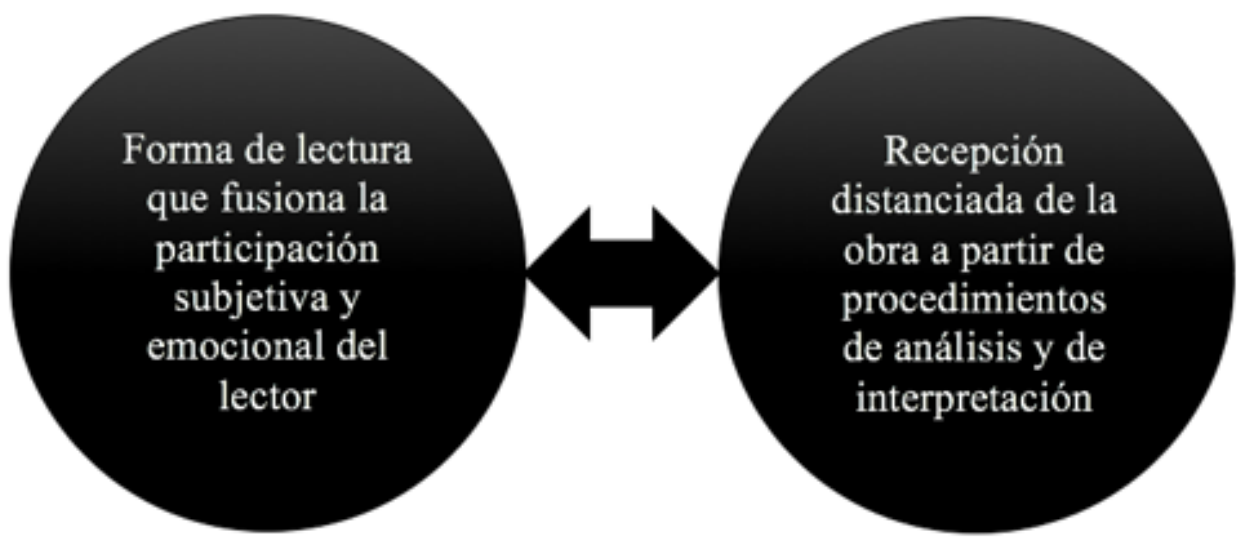

Nota: Adaptado de Colomer, T. (2014). El aprendizaje de la competencia literaria. En: Lomas, C. (coord.). La educación lingüística, entre el deseo y la realidad. Barcelona: Octaedro.

\footnotetext{
${ }^{27}$ El teórico literario inglés H. M. Bierwich definió la competencia literaria como: "una específica capacidad humana que posibilita tanto la producción de estructuras poéticas como la comprensión de sus efectos". (Citado por Colomer, 2014, p. 112).
} 
Es interesante ver en esta propuesta que, por un lado, se introduce por primera vez el valor del lector en la construcción de significado de los textos literarios (muy en línea con la propuesta de la teoría de la recepción de Iser). Y por otro, se propone la lectura crítica de la literatura como uno de los objetivos del educación secundaria, lo que implica para los estudiantes el conocimiento y apropiación de formas de análisis teórico para valorar los textos literarios.

También el profesor Antonio Mendoza Fillola (Universidad de Barcelona) ha hecho aportes interesantes al concepto de competencia literaria al sumarle dos componentes (ver esquema $5)$.

\section{Esquema 5. Componentes de la competencia literaria}

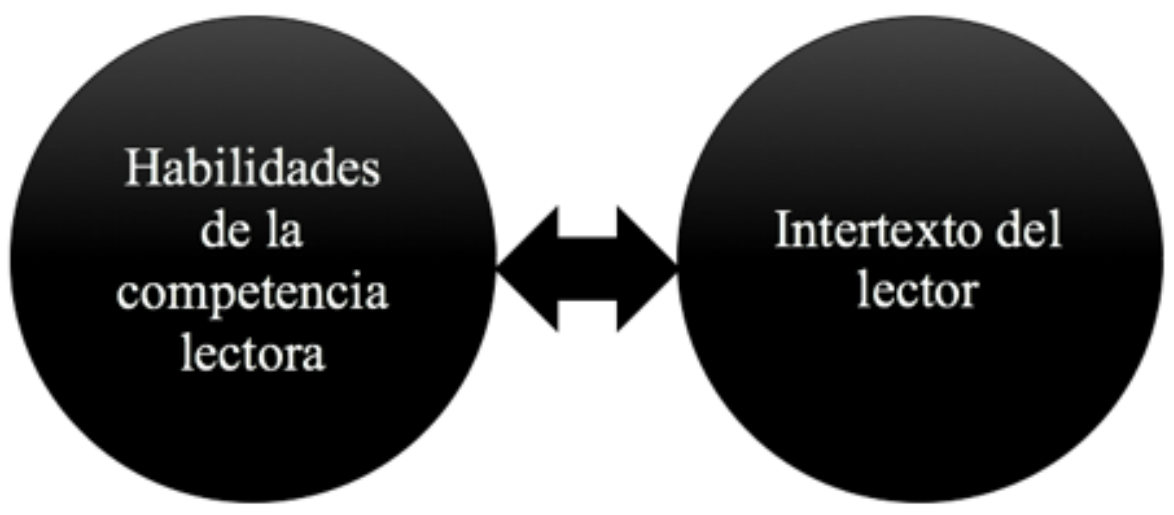

Nota: Adaptado de Mendoza Fillola, A. (2012). Leer hipertextos: del marco hipertextual a la formación del lector literario. Barcelona: Octaedro.

Desde la perspectiva de Mendoza Fillola, no hay lectura literaria de calidad sin dominio previo de las habilidades de lectura tanto en el nivel microtextual como macrotextual ${ }^{28}$ (Mendoza Fillola, 2013) y de la activación de las competencias de intertextualidad ${ }^{29}$, que él ha denominado como el:

amplio fenómeno de recreación, reelaboración o reescritura a partir de referentes (re)tomados del entorno cultural, que genera las conexiones, relaciones y

\footnotetext{
${ }^{28}$ En la jerga de nuestros Estándares básicos de competencias en Lenguaje (2006) y de las Pruebas Saber (2014), se traduce como dominio de las competencias literal, inferencial y crítica.

29 "Todo texto es un intertexto", dice Barthes (1989); "Presencia de un texto dentro de otro (por cita, alusión, referencia)", agrega Genette (1989).
} 
referencias entre textos, media y géneros. (p. 12).

Esto es que sin una red textual ${ }^{30}$, no se comprenden creativamente y críticamente los textos literarios.

El concepto de competencia literaria no ha sido divulgado suficientemente en Colombia, si bien es sugerido por los Estándares Básicos de Competencias en Lenguaje (2006) cuando aclara que la enseñanza literaria en las aulas...

“obedece a la necesidad de consolidar una tradición lectora en los estudiantes a través de la generación de procesos sistemáticos que aporten al desarrollo del gusto por la lectura, es decir, al placer de leer poemas, novelas, cuentos y otros productos de la creación literaria que llenen de significado la experiencia vital de los estudiantes y que, por otra parte, les permitan enriquecer su dimensión humana, su visión de mundo y su concepción social a través de la expresión propia, potenciada por la estética del lenguaje. (p. 25).

Queremos a través de esta investigación proponer un desarrollo de la competencia literaria que favorezca condiciones de posibilidad gratificante para la lectura en el aula de las novelas Paso a paso (Irene Vasco) y Era como mi sombra (Pilar Lozano) y que tome en consideración estos axiomas:

1) Como todos los aprendizajes, el de la literatura debería ser: i) significativo ii) motivado iii) internalizado iv) práctico v) autónomo vi) epistémico.

2) Los textos literarios son valiosos de leer porque nos ayudan a construir la subjetividad, a ser más críticos y libres ante las contingencias de la vida.

3) La idea de enseñar historia literaria está en crisis.

4) Tres objetivos centrales del trabajo de un profesor de lenguaje son: a) formar lectores, b) construir hábito lector y c) desarrollar la competencia literaria.

5) Los llamados "controles de lectura" para evaluar la comprensión de obras literarias solo generan entre los estudiantes plagio y desinterés.

6) Los textos literarios presentan variedad en sus dificultades de comprensión. Es mejor comenzar a leerlos por los menos complejos y avanzar hacia más complejos (los

\footnotetext{
${ }^{30}$ Cfs en la secuencia didáctica (p. 161) lo que entendemos por "red textual".
} 
clásicos, por ejemplo). Y leer diferentes géneros: novela gráfica, cómics, literatura infantil y juvenil, biografías, periodismo, poesía y teatro.

7) Hay que combinar formas de lectura heterónoma y lectura autónoma para ayudar a los más inexpertos a volverse más expertos.

8) Los ritos son esenciales en nuestra vida. La literatura debería tener su momento ritual (su rutina) en el aula cada semana.

9) A todos nuestros estudiantes no les impacta la literatura. Pero no deberíamos descuidarlos como lectores. Les podrían interesar otro tipo de libros: los informativos.

10) La literatura es un lenguaje de naturaleza intertextual. La lectura de un libro literario debería estar acompañada de las artes con las que se relaciona: cine, música, pintura, fotografía, arquitectura, etc.

11) Las nuevas tecnologías que se basan en internet y en las nuevas tecnologías (blogs, chats, redes sociales, podcast, aplicaciones) podrían ayudar a que los estudiantes se interesen en la literatura.

Mi opinión ${ }^{31}$ es que al igual que con ciertos aprendizajes de la lengua (la codificación y la decodificación alfabética, la ortografía, la gramática) seguimos enseñando y evaluando como hace cien años. La enseñanza de la historia literaria y de los textos canónicos de la literatura colombiana y occidental es una herencia del periodo nacionalista, a comienzos del siglo XX, que ha resistido todos los cambios curriculares y de programas que desde entonces se han dado en Colombia. Viejas ideas que persisten: en primaria, enseñar, generalidades de los tipos de texto en los que se expresa la literatura (fábula, cuento, poema); en secundaria, la lectura "obligatoria" de la literatura colombiana (en grado octavo), latinoamericana (en noveno), española (décimo) y universal (once).

¿Terquedad de los maestros? ¿Una episteme que no acepta la autorreflexión? ¿Prácticas ancladas en la vida escolar? No parece haber una respuesta definitiva. Si revisamos la vivencia escolar de cualquier persona mayor de veinte años, encontramos que en general su experiencia de la lectura literaria no ha sido significativa, ni grata. Incluso hoy sigo oyendo

\footnotetext{
${ }^{31}$ Aquí utilizamos apartes de nuestro ensayo Formación de lectores, competencia literaria y evaluación: un reto pendiente (2013, p. 49-52). Recuperado de: http://bit.ly/1PZUvc8
} 
estudiantes de secundaria que gritan: "Odio leer"32. Este solo hecho nos debería llamar la atención a los maestros de Lenguaje y llevarnos a las preguntas: “¿qué no estamos haciendo bien?, ¿por qué estamos fracasando?”, pues está claro que no podemos seguir culpando a los estudiantes de ese choque con los textos literarios.

Hay casos de excepción, desde luego, y esos casos nos enseñan qué se puede hacer para mejorar la didáctica y la evaluación de la literatura en nuestras aulas. Varios de los escritores más reconocidos de nuestros país - por citar un ejemplo cercano- han reconocido que mucho de su vocación lectora la deben a una maestra de primaria que les leía cuentos cada mañana antes de comenzar la clase o a un docente de secundaria con el que "desbarataban" los textos literarios $^{33}$.

En consecuencia, un debate urgente que debemos enfrentar podría girar alrededor de estas preguntas: ¿cuál es el sentido de la enseñanza de la literatura en nuestras aulas?, ¿qué esperamos que lean y aprendan los estudiantes?, ¿cómo debemos evaluar ese aprendizaje?

Desde mi perspectiva, es urgente pasar de un paradigma basado en la prescripción literaria y en la obligatoriedad de leer, a uno en que nuestra tarea de docentes de español sea formar lectores y escritores competentes ${ }^{34}$. Se dirá que es una fórmula fácil de enunciar, pero compleja de llevar a la práctica, y eso es cierto. Pero esa fórmula resume nuestra tarea y la dimensión del desafío que tenemos en frente. Para empezar propongo que introduzcamos en la agenda de discusión dos conceptos o problemas: la formación de lectores y el desarrollo de la llamada competencia literaria.

El reto de formar lectores, en mi opinión, involucra un trabajo conjunto con el bibliotecario escolar, los profesores de las otras áreas y los padres (ver esquema 7). El docente de Lenguaje tiene la tarea predominante de enseñar a comprender los textos literarios y los docentes de las otras áreas, los textos académicos (expositivos, argumentativos, descriptivos, discontinuos). En la construcción de hábitos de lectura de los niños y jóvenes requerimos

\footnotetext{
${ }^{32}$ Aquí se refieren obviamente a la lectura de obras literarias "clásicas", pues leer lo tienen que hacer todo el tiempo. No se concibe ningún tipo de aprendizaje sin ser lector activo.

${ }^{33}$ Nuestro prestigioso Nobel Gabriel García Márquez ha contado cómo su formación de lector, en la adolescencia, estuvo notoriamente influida por la guía de su maestro Carlos Julio Calderón, quien lo introdujo en la poesía clásica española y en el piedracielismo colombiano. Cfs. García Márquez (2002, p. 233).

${ }^{34}$ Sobre este aspecto, ya hace más de diez años, hizo notorios aportes el profesor español Carlos Lomas. Cfs. http://www.cerlalc.org/Escuela/datos/entrevista.doc.
} 
contar, sin duda alguna, con el apoyo de otros mediadores como el bibliotecario escolar (o el bibliotecario público, en su defecto), los padres y, si es posible, animadores de lectura externos. El hábito de lectura se refleja en una conducta asertiva hacia los libros y la lectura por parte de los estudiantes. Una muestra de ese hábito es pedir prestado libros de la biblioteca escolar y mostrar evidente gusto por dialogar y recrear con el docente y los compañeros los libros de literatura que estén leyendo.

\section{Esquema 6. Construcción de un lector}

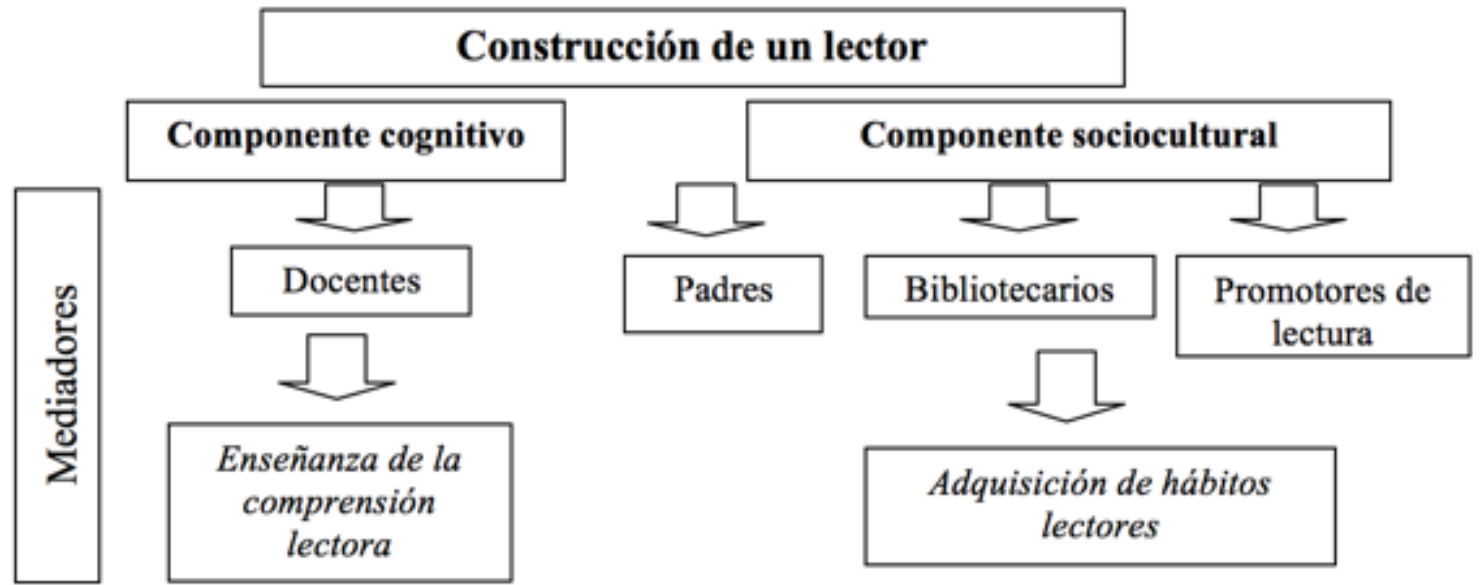

Nota: Elaboración propia.

Esa formación de lectores exigirá tomar en cuenta que los niños, primero, son lectores heterónomos y con el paso de la escolarización deberán convertirse en lectores autónomos ${ }^{35}$, en secundaria (ver esquema 8).

\footnotetext{
${ }^{35}$ Entendemos por lector heterónomo aquel que depende de un adulto para la comprensión de los textos; el lector autónomo es aquel que solo enfrenta los retos que le plantea un texto y los resuelve mediante la puesta en práctica de habilidades esencialmente metacognitivas.
} 
Esquema 7. Dos formas de lectura: lectura heterónoma y lectura autónoma

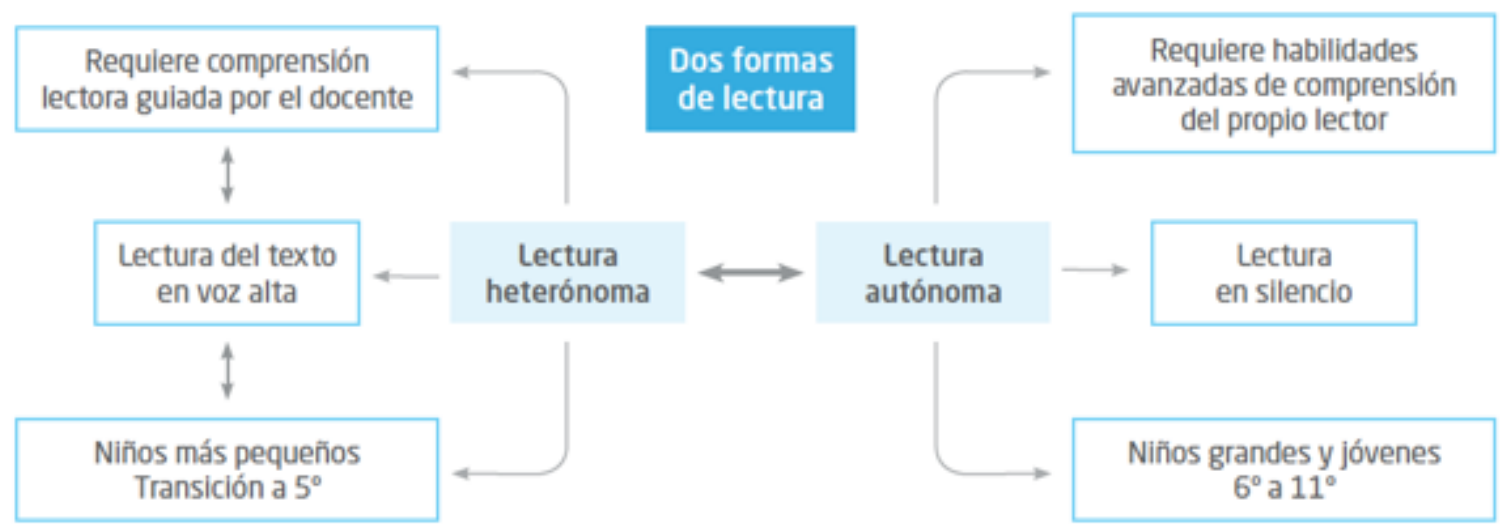

Nota: Elaboración propia.

Bajo este principio vigotskiano de alcanzar nuevas zonas de desarrollo próximo en la lectura de los textos a través de la alfabetización durante once años mínimos en el colegio, será fundamental organizar planes lectores que observen tanto los intereses lectores, variados, de nuestros estudiantes y las competencias lectoras que requieren para comprender, desde los textos más sencillos a los textos más difíciles de entender. Obsérvese un ejemplo de esa evolución en el esquema 9, en donde se sugiere que el último nivel de lectura sea un libro complejo, en esta caso una novela "clásica" (por ejemplo, sí Crónica de una muerte anunciada; no, Cien años de soledad).

Esquema 8. Progresión en la lectura de textos con jóvenes

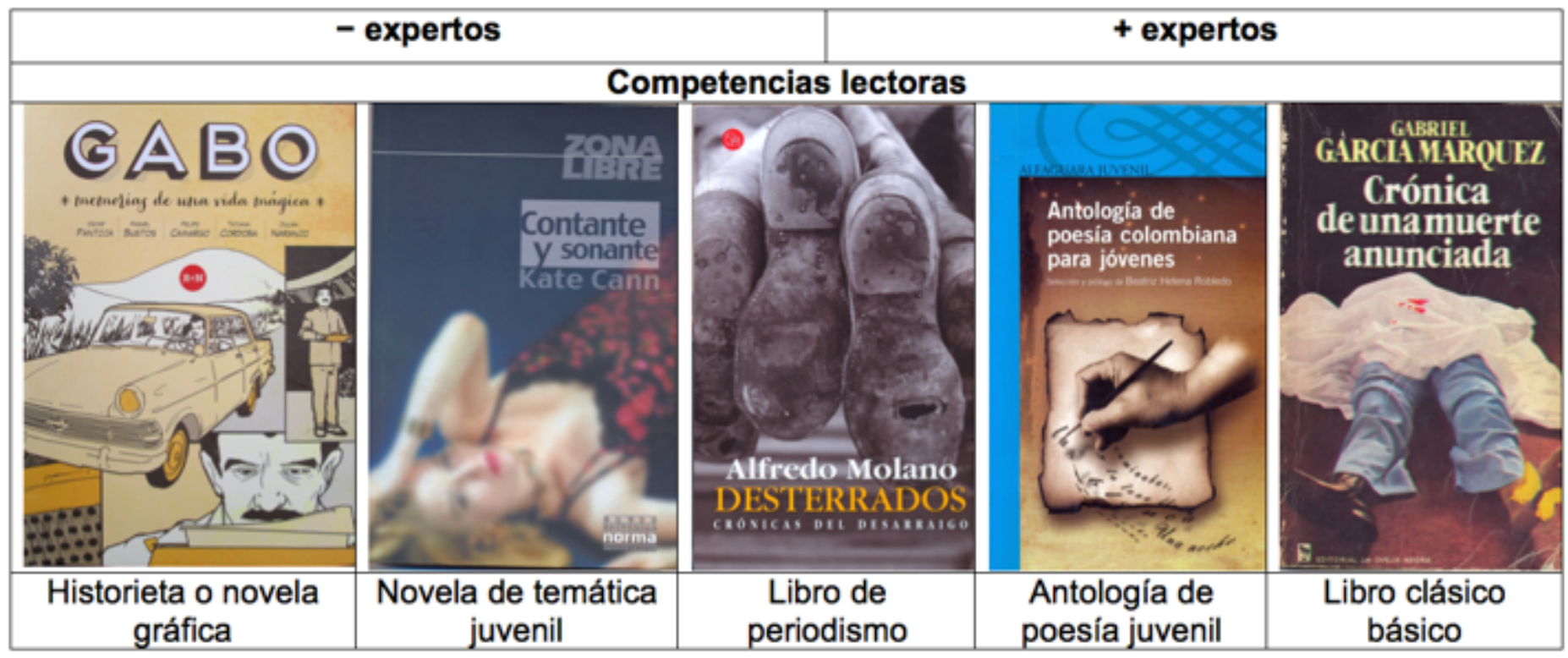


Nota: Elaboración propia.

La competencia literaria, según Colomer (1995, p. 19), incluye los componentes indicados en el esquema 10. Se ha aprovechado para indicar dónde se ubican esos componentes en nuestra Secuencia didáctica ${ }^{36}$.

Esquema 9. Componentes de la competencia literaria y su ubicación en la Secuencia didáctica (SD)

\begin{tabular}{|r|l|c|}
\hline No. & \multicolumn{1}{|c|}{ Componente } & Sesión en la SD \\
\hline 1. & Suscitar la implicación y la respuesta de los lectores. & Sesión 9 \\
\hline 2. & Construir el significado de manera compartida. & Sesión 7 \\
\hline 3. & $\begin{array}{l}\text { Ayudar a progresar en la capacidad de hacer } \\
\text { interpretaciones más complejas. }\end{array}$ & Sesiones 11 y 12 \\
\hline 4. & $\begin{array}{l}\text { Prever actividades que favorezcan todas las operaciones } \\
\text { implicadas en la lectura. }\end{array}$ & Sesión 8 \\
\hline 5. & $\begin{array}{l}\text { Interrelacionar las actividades tanto de recepción como } \\
\text { de expresión literarias, tanto en su forma oral como } \\
\text { escrita. }\end{array}$ & Sesión 13 \\
\hline
\end{tabular}

Nota: Adaptación de Colomer T. (1995). "La adquisición de la competencia literaria”. En: Textos. Didáctica de la Lengua y de la Literatura, (4), pp. 19-25.

Lo que buscamos en definitiva es que la lectura literaria tenga carácter significativo para los jóvenes en las aulas, pero ello supone un cambio drástico en las representaciones que los docentes tienen sobre el valor de la literatura en la vida de las personas (ver esquema 10). Ese cambio supondría observar algunas de las actitudes enumeradas por Rudell (1995, citado por Colomer, 2014, p. 119):

\footnotetext{
${ }^{36}$ La secuencia didáctica (SD) se puede leer en las páginas 152-199.
} 


\section{Esquema 10. Docentes que estimulan la competencia literaria en el aula.}

\begin{tabular}{|r|l|}
\hline 1) & $\begin{array}{l}\text { Engloban la lectura y la escritura a través de secuencias claras y con sentido } \\
\text { propio, presentan los objetivos y explicitan tanto los resultados como las } \\
\text { estrategias que se van utilizando. }\end{array}$ \\
\hline 2) & $\begin{array}{l}\text { Promocionan la lectura de obras enteras o textos largos, una estrategia avalada } \\
\text { también por los análisis derivados de los informes de Pisa sobre la lectura. }\end{array}$ \\
\hline 3) & $\begin{array}{l}\text { Analizan previamente las características de los textos para escoger el foco -no } \\
\text { todo cada vez-, prevén su vínculo con los objetivos seleccionados -y su relación } \\
\text { con la escritura de los alumnos si procede- y preparar el desarrollo concreto de la } \\
\text { lectura. }\end{array}$ \\
\hline 4) & $\begin{array}{l}\text { Anuncian la función de la lectura o escritura de cada texto para que los alumnos } \\
\text { sepan dónde focalizar su atención. }\end{array}$ \\
\hline 5) & $\begin{array}{l}\text { Establecen una guía colectiva y funcional en el aula, interaccionan intensamente } \\
\text { con los alumnos e intentan acercarlos a los aspectos estéticos y emocionales del } \\
\text { texto. }\end{array}$ \\
\hline 6$)$ & $\begin{array}{l}\text { Fomentan una lectura cooperativa que estimule la discusión de los textos para } \\
\text { favorecer estrategias inferenciales, interpretativas y criticas. }\end{array}$ \\
\hline 7) & $\begin{array}{l}\text { Plantean tareas complejas y exigentes, pero con un desarrollo sostenido a través } \\
\text { de muchos elementos de apoyo que permiten que los alumnos puedan mantener } \\
\text { el control y les dan la oportunidad de triunfar satisfactoriamente para ellos } \\
\text { mismos. }\end{array}$ \\
\hline 8 ) & $\begin{array}{l}\text { Explicitan y sistematizan los aprendizajes de los alumnos para que sean } \\
\text { conscientes de su progreso, adquieran conocimientos e interioricen formas } \\
\text { eficaces de proceder, un motor extraordinariamente potente de gratificación del } \\
\text { saber. }\end{array}$ \\
\hline 9) & \begin{tabular}{l} 
Ayudan individualmente a los alumnos en sus dificultades especificas. \\
\hline
\end{tabular} \\
\hline
\end{tabular}

Nota: Adaptado de Rudell R. B. (1995). Those influential literacy teachers: meaning negociators and motivation builders. En: The Reading Teacher, 6 (48), 454-463.

Más allá de toda esta parafernalia sobre la competencia literaria, el verdadero logro será que nuestros estudiantes recuerden de manera inolvidable que la literatura les ayudó a entender algo que no habían entendido antes, a ser más humanos y críticos, a tener referentes para darle coherencia al mundo. En definitiva, que los ayudó a crecer, a construir su subjetividad, y les proporcionó un tipo de experiencia y de lenguaje únicos, esencial a lo largo de sus $\operatorname{vidas}^{37}$.

\footnotetext{
${ }^{37}$ Esta reflexión final es un homenaje a mi profesor de literatura en educación secundaria en el Colegio San Pedro Nolasco de Bogotá, Pedro Romero, quien ayudó a consolidar en mí ese amor fanático, absoluto, sin condiciones, por la verdad que instaura la Literatura.
} 


\section{INTEGRACIÓN DE LAS COMPETENCIAS CIUDADANAS EN LA VALORACIÓN LITERARIA}

En esta investigación hemos incluido el desarrollo de una competencia ciudadana ${ }^{38}$ en la sesión 13 de la Secuencia didáctica. Esta competencia es la empatía. Nos parece clave hacerlo porque consideramos que a través de la literatura también es posible elaborar discernimiento moral y discutir las emociones que nos generan los hechos de la realidad.

\section{Esquema 11. Ubicación de la sesión de Competencia ciudadana dentro de la Secuencia didáctica (SD)}

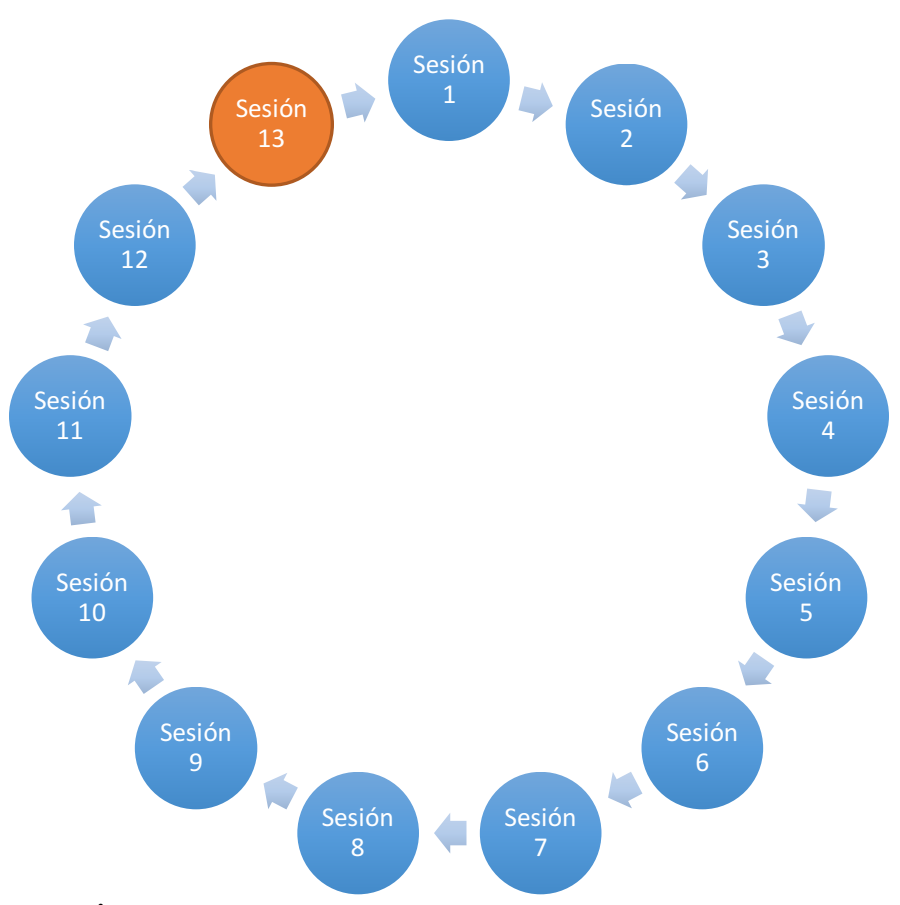

Nota: Elaboración propia.

La empatía ha sido definida de diversas formas por expertos en educación emocional, pero todas apuntan a lo mismo: capacidad para "compartir las emociones de los otros"39, según lo resumen los Estándares de competencias ciudadanas (2006, p. 157). Hoffman (1987) es más preciso, pues establece cómo un niño o un joven pueden llegar a ella:

\footnotetext{
38 Por competencias ciudadanas los Estándares Básicos de Competencias (2006) del MEN entienden el ejercicio por parte niños, niñas y jóvenes del país de "su derecho a actuar como agentes activos y de manera constructiva en la sociedad: para participar activa y responsablemente en las decisiones colectivas de manera democrática, para resolver los conflictos en forma pacífica y para respetar la diversidad humana, entre otros importantes, como proteger el medio ambiente". (p. 154).

39 En inglés hay una metáfora más precisa para definir empatía: "to put oneself in another person's shoes" ("ponerse en los zapatos del otro").
} 
...a través de los indicios expresivos que refleja directamente los sentimientos del otro, o bien por otros indicios que trasmiten el impacto de los acontecimientos externos. (p. 119).

Es decir que la empatía es emocional -un tipo de reacción ante el dolor o el sufrimiento del otro-, pero también es cognitiva, y supone un proceso de "internalización" en palabras de Vygotski (2000, p. 92), ya que exige información reflexionada para tomar la decisión autónoma de participar de lo que siente el "Otro". Agrega Ruiz Silva y Chaux Torres (2010):

La empatía es fundamental para la convivencia en sociedad. Martin Hoffman (2002), por ejemplo, ha mostrado que la empatía contribuye a que las personas se preocupen por ayudar a quienes lo necesitan, eviten herir a otros física o psicológicamente, o busquen el perdón y la reconciliación con otros cuando se dan cuenta que han hecho daño. (p. 28).

Comprender el daño y el sufrimiento que ha causado el conflicto armado en Colombia exige una alta dosis de empatía, y el reconocimiento de que solo la verdad, la justicia y la reparación -que se supone es la tarea del Tribunal de Paz que se organizará tras el Acuerdo con las Farcpodrán dar sentido al perdón de las víctimas después de los "terribles hechos" (como dice Ernst Jünger $)^{40}$ que cometieron los señores de la guerra: los victimarios.

Lo que queremos con la sesión 13 de la SD no es que los jóvenes lectores lloren o se depriman o se sientan culpables. No buscamos generar dramatismo de ocasión y que luego se pase al olvido. Esas reacciones pueden ser "normales" -y comprensibles- luego de leer Paso a paso, de Irene Vasco o Era como mi sombra, de Pilar Lozano, porque estas obras acuden intencionalmente a tocar las emociones del lector ${ }^{41}$.

Lo que buscamos es una actitud más basada en la empatía ética y que se fundamente en el razonamiento. Y esto en respuesta al hecho que lo que observamos en muchas aulas de clase es desinformación, que se refleja en una actitud evasiva ante problemas complejos, o una actitud agresiva. Hay jóvenes que a la pregunta de si en Colombia hay -o hubo- guerra,

\footnotetext{
${ }^{40}$ En El corazón aventurero (2003, p. 104).

${ }^{41}$ El profesor australiano T. H. Carney (1992) propuso (y es un aspecto que comparto) que una forma de evaluar si un texto era comprendido por los niños consistía en observar las reacciones emocionales que tenían ante el él: "la respuesta del lector puede adoptar numerosas formas espontáneas como suspiros, lágrimas, carcajadas, relectura, una recomendación personal". (p. 55).
} 
responden que no; o a la pregunta de qué es un guerrillero, dicen que es un "malo" y que hay que matarlo. Pero si contrapreguntáramos: “¿y si ese guerrillero es un niño, también hay que matarlo?", habría que observar las respuestas ante el dilema moral.

Toda forma de empatía en relación con el conflicto armado pasa, sin duda, por el "desarme de los espíritus" y, claro, por la adquisición de información confiable, que finalmente es lo que esperamos lograr con la lectura de la sección Contexto histórico, que antecede a los análisis de las dos novelas juveniles objeto de estudio de esta investigación.

Pero esencialmente hemos incluido el componente de empatía, en atención a lo que dice el filósofo español Manuel Reyes Mate (2010) con respecto a la necesidad de construir memoria de las víctimas (no solo memoria de los hechos históricos):

Esa motivación moral consiste en entender el sufrimiento del otro como algo propio. Lo que supera a la idea schmittiana de política es una ética de la compasión o de la alteridad, como diría Lévinas. (p. 45).

Esa ética de la compasión fue la que movió a un sacerdote español, el padre Bartolomé de las Casas, a denunciar en el siglo XVI las atrocidades que durante la Colonia estaban cometiendo sus connacionales con los indígenas ${ }^{42}$. Es una ética basada en no aceptar la injusticia, pero tampoco el dolor del otro, y que se manifiesta a través de la denuncia.

Por eso en la sesión 13 de la Secuencia didáctica hemos incluido una actividad para desarrollar este estándar de las competencias ciudadanas:

Expreso empatía ante grupos o personas cuyos derechos han sido vulnerados (por ejemplo, en situaciones de desplazamiento) y propongo acciones solidarias para con ellos. (2006, p. 179).

La actividad la hemos adoptado del magnífico taller que organizó el poeta Javier Naranjo con la Red de Bibliotecas del Banco de la República. Básicamente consiste en invitar a los niños y jóvenes a pensar en la palabra PAZ y otras asociadas con el tema del conflicto armado en Colombia.

\footnotetext{
${ }^{42}$ En Brevísima relación de la destrucción de las Indias $(1511,2013)$.
} 
Para nosotros es claro que los textos literarios -que pretenden alcanzar un valor estético permanente en la sociedad- no solucionan nada en el mundo de lo práctico, pero sí queremos insistir en que pueden servir de lugar de encuentro en la palabra para que los jóvenes lectores reparen en lo que no habían reparado. Insistimos que no se trata de que "sufran" el drama de los otros, sino que lo comprendan, y lo asuman como propio en una perspectiva crítica. Probablemente ninguno de los jóvenes lectores contemporáneos de Paso a paso ha tenido a su padre secuestrado como Patricia, o ha sufrido en carne propia la tensión de casi morir en un combate como le sucede al niño guerrillero, protagonista de Era como mi sombra.

Pero y si al leer una novela nos transformamos en esos personajes, ¿qué nos queda en el corazón sino la empatía? 


\section{Capítulo 2}

\section{FicCionalización del SeCUESTRo en Paso A PASO DE IRENE VASCO}


FICHA DEL LIBRO

\begin{tabular}{|l|l|l|l|}
\hline Título & \multicolumn{3}{|l|}{ Paso a paso. Vuelve papá } \\
\hline Autora & Irene Vasco & Ilustradoras & $\begin{array}{l}\text { Esperanza Vallejo } \\
\text { (carátula) } \\
\text { Natalia Vallejo (viñetas } \\
\text { interiores) }\end{array}$ \\
\hline Editorial & Carlos Valencia (1 ${ }^{a}$ edición); Panamericana & $2^{a}$ edición) \\
\hline Fecha de publicación & $1995 ;$; 1997 & Paginaje & 78 páginas \\
\hline Género & Novela juvenil, realismo intimista & Secuestro \\
\hline Eje temático articulado con el conflicto armado
\end{tabular}

\section{BIOGRAFía DE LA AUTORA}

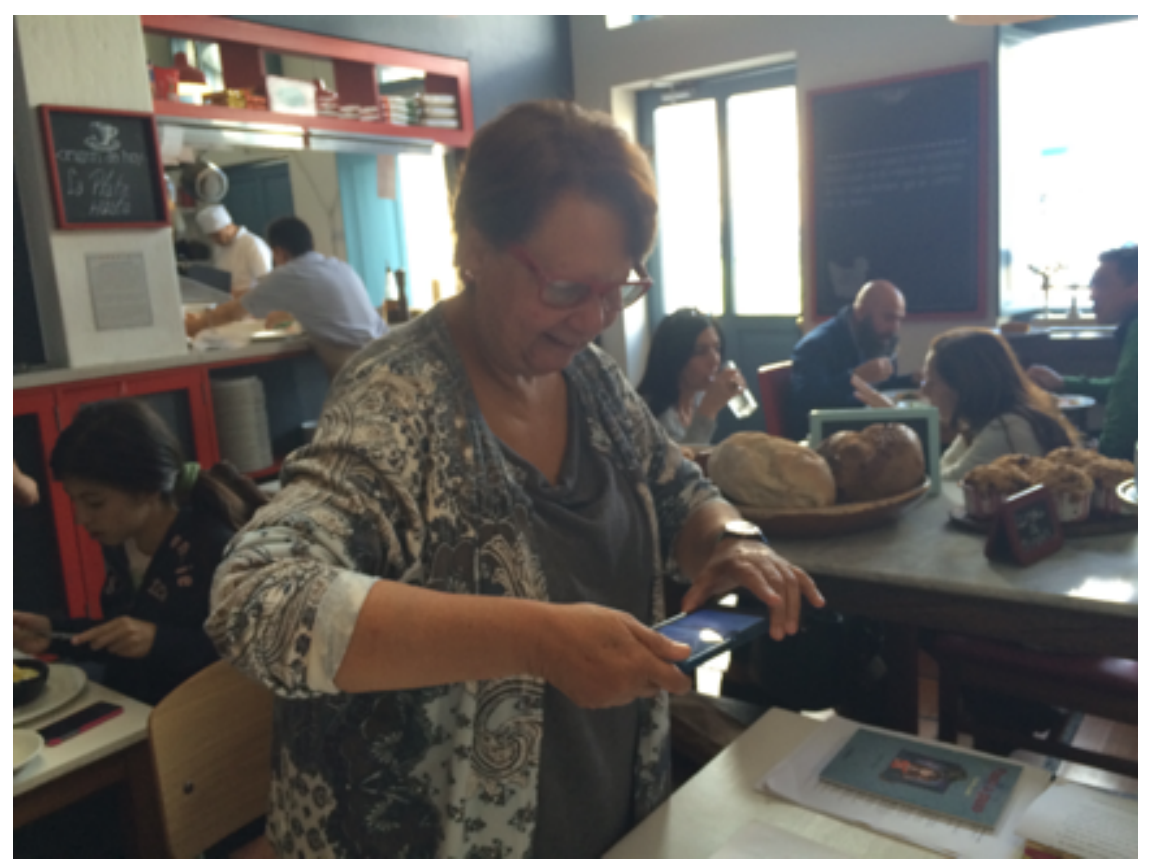

Irene Vasco. (Bogotá, 1952). Hija del exembajador y asesor presidencial Gustavo Vasco y de la cantante, pedagoga musical y activa cofundadora de la televisión colombiana, Sylvia Moscovitz. Estudió su educación secundaria en el Liceo Francés de Bogotá y es literata de la Universidad del Valle. Ha vivido en los Estados Unidos, Venezuela y Brasil. A su retorno en Colombia, su inclinación por las artes se materializó al trabajar con Gian Calvi, un reconocido artista gráfico. Su primer gran salto a la literatura lo dio con Conjuros y 
sortilegios (1990) que la crítica literaria de LIJ en Colombia considera un clásico de la poesía para niños, y que fue incluido en la lista de los Mejores libros infantiles del Banco del Libro de 1994. Otros de sus libros de literatura más reconocidos son la novela Mambrú perdió la guerra (2012) y el álbum Letras al carbón (2015). Irene Vasco, además, ha sido librera (fundó con Cristina y Carmiña López la librería Espantapájaros en Bogotá) y promotora de lectura (ha trabajado con la Fundación Rafael Pombo, el Plan Nacional de Lectura del Ministerio de Educación Nacional, la red de bibliotecas del Banco de la República y Fiesta de la Lectura, el reconocido programa de alfabetización para madres comunitarias dirigido por el Icbf). También ha ejercido de traductora (ha trasladado al español obras de Ana María Machado, Ligya Bojunga, Marina Colasanti y Rubem Fonseca) y es una activa divulgadora de las maravillas de Colombia y de su historia (de ello dan testimonio sus libros Lugares fantásticos de Colombia y La Independencia de Colombia: así fue). Su literatura es predominantemente realista, crítica con la situación política colombiana ${ }^{43}$. Tiene claro que su literatura cumple una función emancipadora, dialogal:

Los niños están en la guerra. Los niños la viven. Puede que muchos no vivan las bombas y las minas en su cuerpo, pero todo el tiempo están oyendo los noticieros, están oyendo del paro y no hay colegio porque los campesinos están peleando por sus derechos. Nada es ajeno a ellos. Y ellos quieren saber. Y la literatura es una muy buena manera de entablar diálogos, de iniciar conversaciones más simbólicas sobre la vida y la muerte, la violencia y la paz, la libertad y el secuestro (Torres Duarte, 2013, p. 18).

\section{CONTEXTO HISTÓRICO ${ }^{44}$}

El secuestro -la retención forzada de una persona a cambio de algún beneficio político o económico- fue una de las armas más letales que usaron los señores de la guerra, los victimarios $^{45}$. Según establece el GMH, entre 1970 y 2002 hubo en Colombia 27.000

\footnotetext{
${ }^{43}$ Fuentes de la información: Robledo, B. H. (2010, p. 901); Sánchez Lozano, C. (2013, p. 83); Ospina, C. E. (2013), Torres Duarte, J. D. (2013, p. 18).

${ }^{44}$ Este Contexto histórico es netamente general y no aborda el fenómeno en profundidad. Cumple la función de darle un marco informativo básico a los docentes, que puede ser ampliado por ellos.

${ }^{45}$ Michael Frühling, Alto Comisionado de Naciones Unidas, describió así esta práctica delictiva “(...) constituye un bárbaro ataque contra la capacidad individual de autodeterminación de las personas [...] [y que] no solo afecta la autonomía del ser humano para determinarse por sí mismo en el tiempo y en el espacio. Todo secuestro implica también la cosificación de la persona, la brutal reducción de ella al triste papel de mueble,
} 
secuestros (2013, p. 64) a causa del conflicto armado. El mayor nivel de plagios -16.000- se dio entre 1996 y 2002 (periodos presidenciales de Ernesto Samper Pizano y Andrés Pastrana). El 90 por ciento de los secuestros los cometió la guerrilla de las Farc y el 10 por ciento restante entre paramilitares y delincuencia común (GMH, 2013, p. 65). La cifra es absolutamente escalofriante y revela el nivel de degradación que el conflicto alcanzó en esos años.

En la cronología del secuestro -esencialmente el de tipo político- el primero fue cometido por parte de la guerrilla del M-19 en 1976 (el sindicalista José Raquel Mercado) y fue parte de su estrategia publicitaria para buscar aliados en la opinión pública -sobre todo entre sectores populares universitarios y urbanos a los que les interesaba llegar- y castigar a la "burguesía” por su arrogancia y su desinterés por los problemas sociales (Villamizar, 1997, p. 15). El siguiente secuestro - el del industrial Hugo Ferreira, en 1977- pese a ser un secuestro de tipo político, pronto se convirtió en secuestro extorsivo, con exigencias económicas por la liberación del secuestrado. Este abrupto cambio redefinió el horizonte y las dimensiones del delito. En adelante las otras guerrillas optaron por el secuestro como forma de captar ingresos para la guerra. Los victimarios adquirieron notoria experticia en manejar por largos periodos - a veces por años- la retención forzada de una persona. Primero fue en caletas o en refugios suburbanos, pero luego el encarcelamiento se sofisticó: diversas personas cumplían funciones específicas. Hacer "inteligencia” para conocer los datos económicos del potencial secuestrado, reconocer sus rutas de viaje cotidiano, planear el plagio y luego hacer el traslado a un lugar donde la policía o el ejército no pudiera llegar con facilidad. Incluso, hubo "expertos" para hacer las llamadas telefónicas a los familiares de la víctima y exigir cuantiosas sumas; otros se "especializaron" en recoger el dinero en lugares rurales o selváticos. No faltaba el fotógrafo improvisado que tomaba la imagen del secuestrado con un periódico del día para hacerla llegar a la familia. El horror se sofisticó en el transcurso de 10 años (1990-2000) y los maestros en el arte del mal fueron guerrilleros, la mayoría de origen campesino (GMH, 2013, p. 67).

con total desprecio por su dignidad". (GMH, 2013, p. 299). 
Imagen 3. Las huellas del secuestro. Íngrid Betancourt en mitad de la selva, 2007

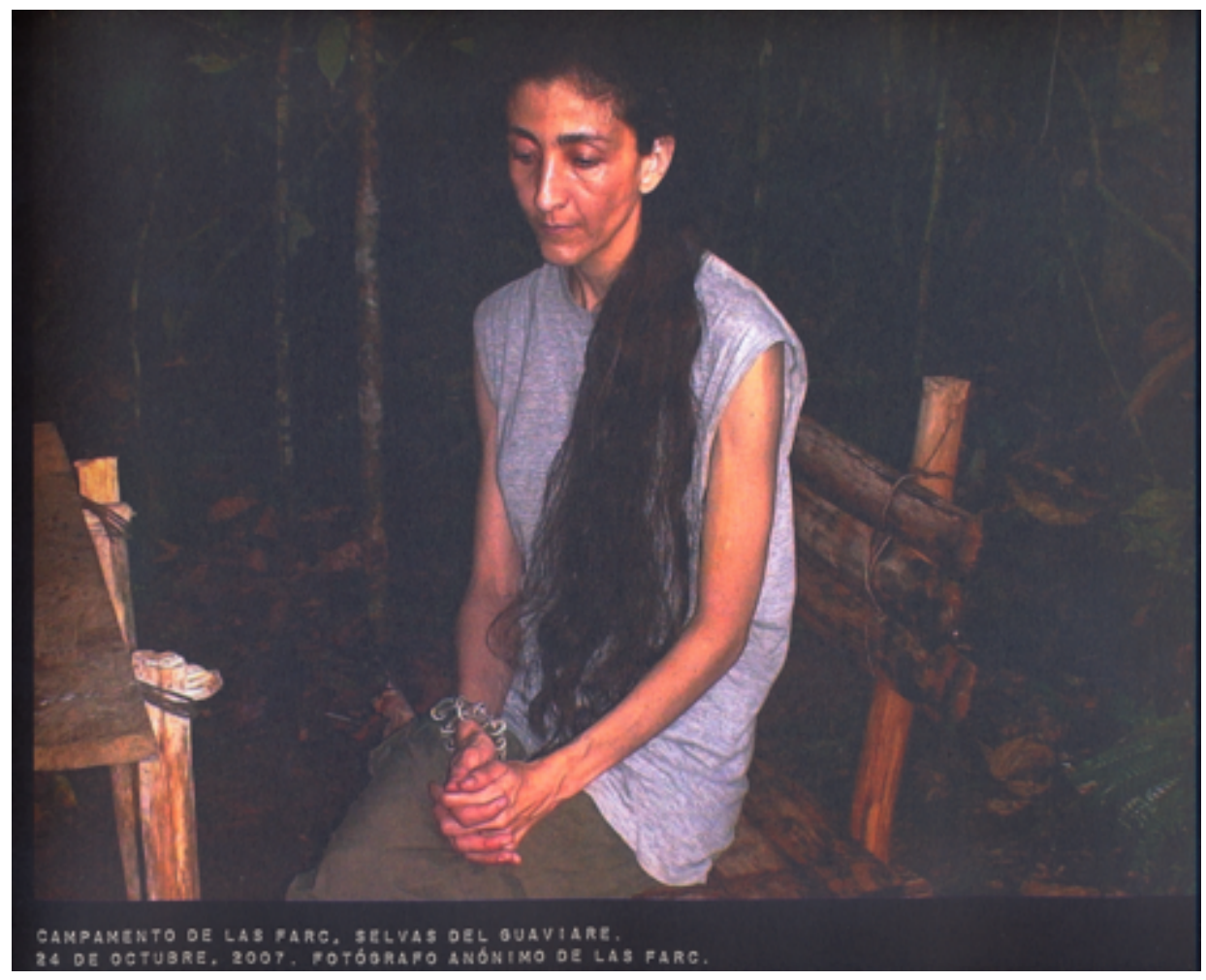

Nota: Tomada de Ferry, S. (fotógrafo) (2012). Violentología: un manual del conflicto colombiano. Bogotá: Ícono.

Pronto la delincuencia común aprovechó la estrategia y empezó a "vender" los secuestrados a la guerrilla por un valor tasado con gran cálculo. El secuestro se convertía en mercado (¿quién da más por el secuestrado?). La deshumanización alcanzó límites escalofriantes. Uno de estos secuestrados, Guillermo la "Chiva" Cortés (quien estuvo en manos de las Farc en 2000 durante 205 días) relata en detalle, en un reportaje elaborado por Alexandra Samper (2013), los vejámenes que traía la transacción:

Serían como las once de la mañana cuando llegó a la casita un hombre vestido de militar. Un tipo muy bien uniformado, con chaqueta, demasiado bien puesto y elegante para la situación, y con un caminado un poco afeminado. Entró a un cuarto de la casa con el tipo que había manejado la camioneta. (...). Yo me quedé en el corredor mirando las matas a sabiendas de que adentro, en un cuarto de la casa, estaban resolviendo mi vida, mi futuro. Yo dependía enteramente de esa conversación. Mi cuerpo era objeto de canje. (...). El tipo salió del cuarto dando un portazo y lo que me dijo me heló el corazón. “¡Ahora sí va saber cómo es la 
vaina!", me espetó con rabia. "Desde este instante usted se encuentra en poder de las Fuerzas Armadas Revolucionarias de Colombia, Ejército del Pueblo, mejor dicho Farc-ep , pa' que le quede claro". (p. 26).

El secuestro alcanzó una dinámica demente a finales de los años 80 del siglo pasado. Ya no fue usado solo por la guerrilla como forma de obtener ingresos, sino también por los narcotraficantes con fines políticos. Pablo Escobar, jefe del Cartel de Medellín, en un tiempo récord, logró retener a figuras representativas de las élites políticas o económicas del país, a cambio de obtener beneficios para que la extradición no prosperara en el Congreso ${ }^{46}$. Y cuando fue acosado por la fuerza pública, reaccionó dando la orden de matar a los secuestrados como sucedió en el caso de Diana Turbay, hija del expresidente Turbay Ayala (1974-1978).

Eduardo Pizarro ${ }^{47}$, historiador, funcionario del gobierno Uribe, y comisionado en La Habana para hacer una de las relatorías de la Comisión Histórica del Conflicto- resalta que el secuestro fue uno de los móviles que encontraron los paramilitares para organizarse y justificar sus actividades criminales (2014, p. 59). El origen del paramilitarismo en Colombia con las AUC (fundada por los hermanos Castaño Gil) tiene que ver mucho con el secuestro y posterior asesinato de su padre, un hacendado de la región de Córdoba, homicidio cometido probablemente por un frente de las Farc. El crimen sirvió de excusa para que los Castaño desataran la más brutal persecución a cualquier persona de la que se sospechara algún tipo de cercanía con la izquierda política fuera ilegal o legal. Y no solo personas, sino colectivos enteros. La masacre espantosa de 43 campesinos en 1988 en Segovia (Antioquia) en 1988, tiroteados en la plaza y en las principales calles del pueblo, acusados de ser simpatizantes de la Unión Patriótica, ofrece un retrato siniestro de hasta dónde había llegado la venganza y la retaliación causada por el secuestro y las acciones de las guerrillas.

Durante mediados de los 90 los secuestros crecieron exponencialmente (Ferry, 2012, p. 40). Las Farc y el Eln formaron cuadros especializados para "fichar" a las víctimas que deberían retener (Valencia, 2014, p. 161). Ya no solo eran empresarios o extranjeros, sino cualquier persona que estuviera en el lugar equivocado. Uno de estos comandantes, Romaña, estableció

\footnotetext{
${ }^{46}$ El reconocido Nobel de literatura Gabriel García Márquez hizo un extenso reportaje sobre el tema, que recogió en el libro Noticia de un secuestro (Norma, 1996).

${ }^{47}$ Hermano del comandante del M-19, Carlos Pizarro Leongómez.
} 
el sistema de "pescas milagrosas" en la vía Bogotá a Villavicencio o en otras autopistas clave del país. Las cantidades que debían pagar los secuestrados podían ser astronómicas o "según el presupuesto del marrano" (la frase es de Romaña), una especie de secuestro exprés de horas, hasta que los familiares de la víctima trajeran el efectivo y lo entregaran a los guerrilleros secuestradores. Todo este proceso de corrupción revelaba cómo no solo los comandantes sino diversos mandos medios de la guerrilla se beneficiaban. El secuestro se había convertido en una empresa criminal estable y su poder de amedrentamiento a la sociedad era tal, que las propias autoridades estaban superadas para responder e imponer sentido de justicia (Duncan, 2014, p. 266).

Los ataques de las Farc a diversas unidades militares entre 1996 y 1998 generó un nuevo tipo de secuestro: el de policías y soldados, que derrotados en medios de los combates debían rendirse y entregarse como prisioneros de guerra. Ya no era un secuestro extorsivo sino con finalidad política: lograr el canje por prisioneros de las Farc en cárceles colombianas. Entraba en una nueva etapa la violación de derechos humanos fundamentales. El monstruoso Mono Jojoy, comandante militar supremo y mano derecho de Tirofijo, encerró a más de 1000 militares en apiñados campos cercados por alambradas, que en mucho recordaron los de los nazis durante la segunda guerra mundial. Cualquier ideología de respeto al ser humano -que en las cartillas comunistas figuraba como valor humanista heredado de la Revolución Francesa- se perdió. 
Imagen 4. Campesinos muestran las pruebas de supervivencia de sus hijos, soldados y policías en poder de las Farc. Febrero de 1997

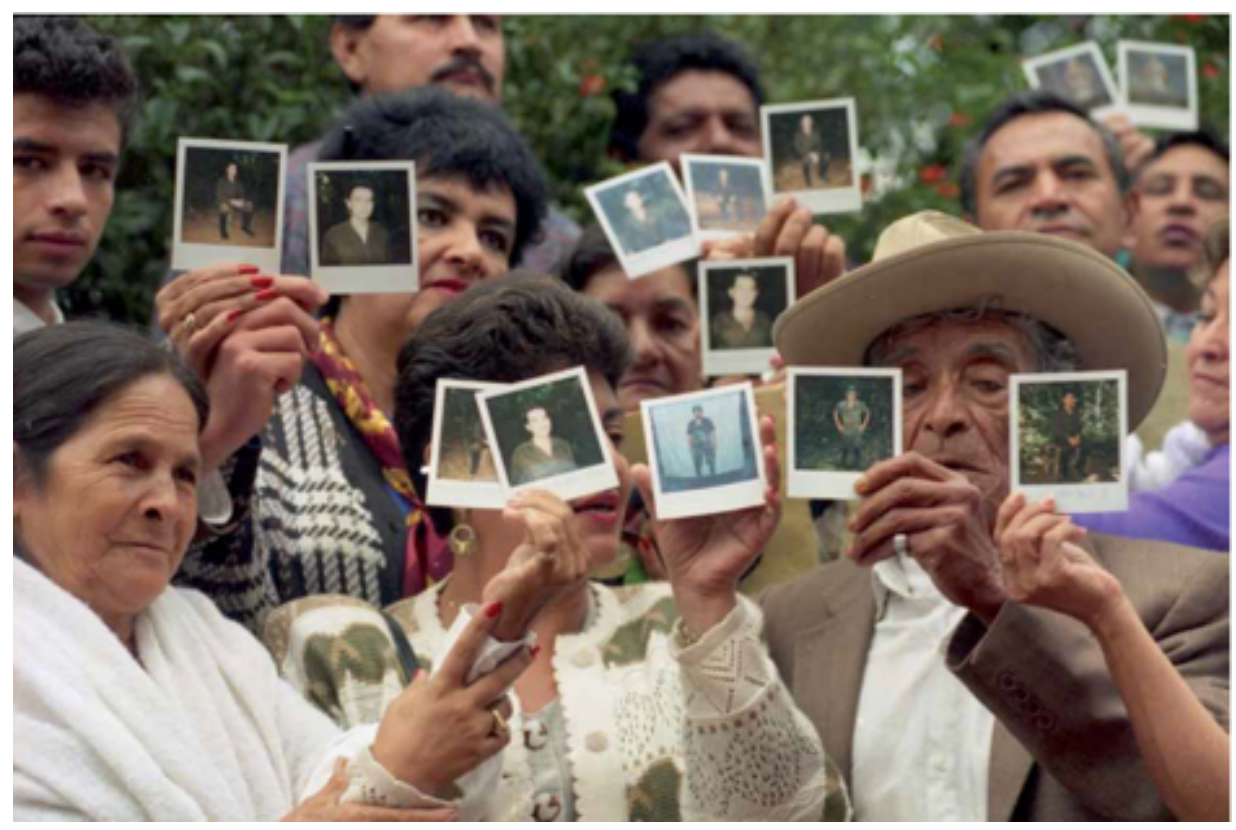

Nota: Tomado de Chávez, G. (fotógrafo). En: GMH (2013). ¡Basta ya! Bogotá: Imprenta Nacional.

La cima del terror originado por el secuestro tuvo su clímax con el plagio de la candidata presidencial Íngrid Betancourt y su asesora Clara Rojas, en 2002, en cercanías a San José del Guaviare, cuando buscaban reanudar el diálogo con las cúpula de las Farc, luego del fracaso de las negociaciones con el gobierno de Andrés Pastrana. Entonces empezaron, en una escala desmedida, el secuestro de políticos de nivel departamental y nacional. El secuestro de los diputados del Valle en 2002 y su posterior asesinato a sangre fría en 2011 pueden dar idea del estado extremo al que había llegado la guerra en Colombia y la voluntad de las Farc ${ }^{48}$ de no ceder ante principios humanitarios ni repensar su posición frente al secuestro. El excongresista Luis Eladio Pérez ofrece un retrato desgarrador de la situación de inferioridad en que se hallaba un secuestrado:

El secuestrado es un ser humillado en lo más íntimo de su dignidad, su cuerpo

\footnotetext{
${ }^{48}$ Esta afirmación incluye a la guerrilla del Eln que cometió secuestros de alto impacto mediático: el del avión de Avianca con 50 personas que iba en la ruta Bucaramanga-Bogotá en 1999, el de la iglesia La María, al sur de Cali en la vía a Jamundí, donde fueron sacadas 186 fieles, también en 1999, y el de más de 40 personas que estaban almorzando en restaurantes de la vía Cali-Buenaventura y que fue registrado con gran crudeza por el periodista Germán Castro Caycedo en Con las manos en alto (2001).
} 
se convierte en mercancía de canje, no tiene ningún derecho, ninguno, ni siquiera ir al baño. Encima de todo no solo sufre por las condiciones a que es sometido, sino porque sabe que su familia también sufre" (Pérez, 2008, p. 28).

Para las víctimas del secuestro las penas y el sufrimiento comenzaban desde el mismo momento de la retención. Movilización en baúles de carros, encadenados, con la boca y los ojos tapados, luego el largo tránsito hacia zonas rurales o selváticas (Chocó, Llanos orientales, Vaupés, Putumayo, Vichada), mala alimentación, caminatas de veinte horas, pésimo sueño por la presión que ejercía la fuerza pública en plan de rescate. Además de ello los maltratos físicos y psicológicos, las amenazas, la carencia de los medicamentos para los enfermos. Los llamados "carceleros" de las Farc hicieron más infame el secuestro a las víctimas al atarlas con cabullas, cadenas y candados en los pies y las manos.

\section{Imagen 5. Gabriel Arturo Villegas en el sepelio de su hija Ana Cecilia Duque, profesora secuestrada y asesinada por el ELN en Cocorná, Antioquia.}

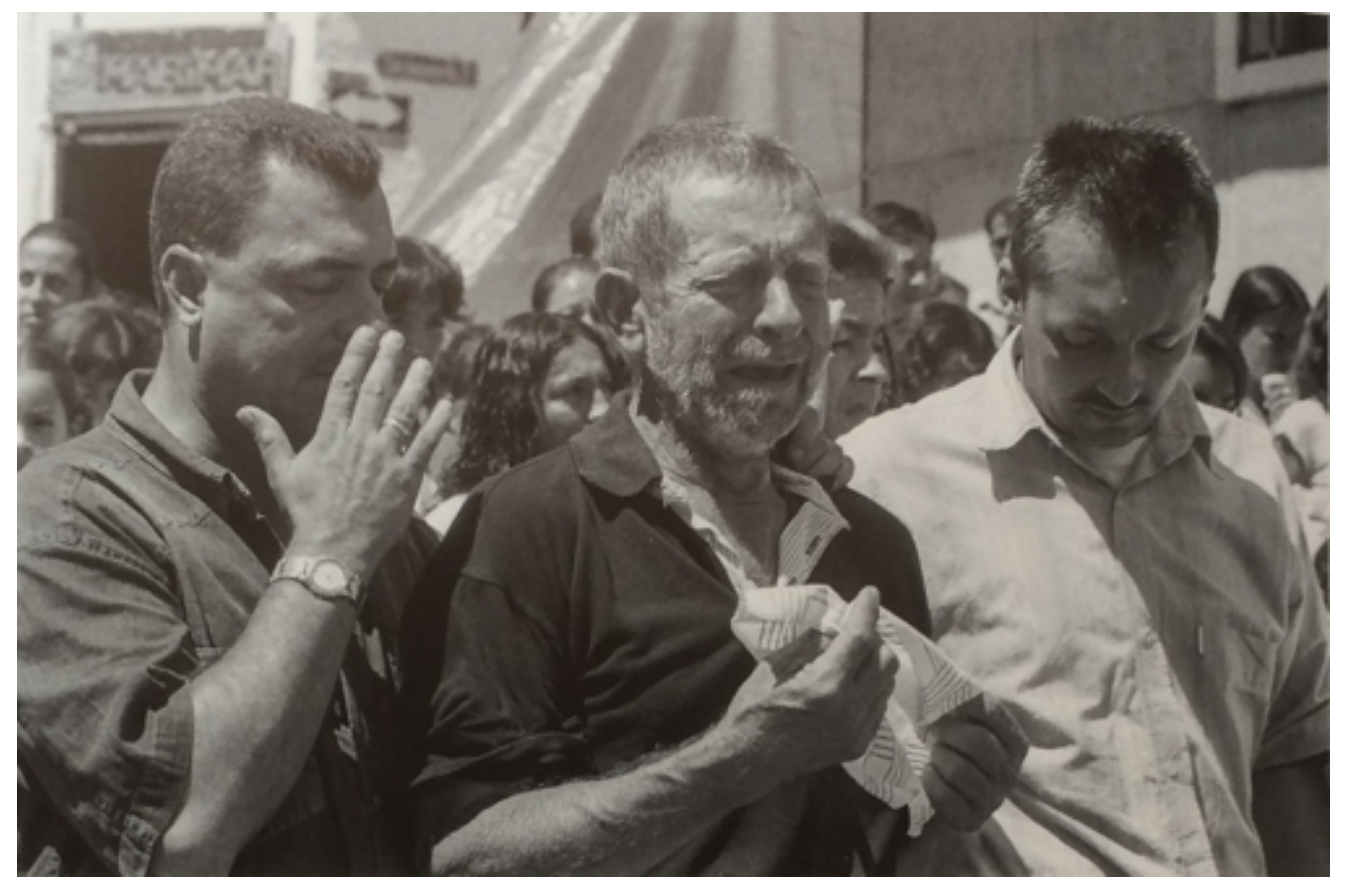

Nota. Tomada de Abad Colorado, J. (fotógrafo). (2015). Mirar de la vida profunda. Bogotá: Planeta.

Las familias de los secuestrados en los pueblos y ciudades veían pasar los días, los meses, los años con cada vez más mayor desesperanza y miedo, pues el rescate militar podría 
significar la muerte de los secuestrados. Se dieron casos dolorosos de hijos que nunca pudieron conocer a sus padres (el episodio del niño con cáncer, Andrés Felipe Pérez, cuyo padre, el soldado Norberto Pérez, fue asesinado por las Farc en 2002, cuando intentó escapar) o de otros que no pudieron alcanzar la libertad porque murieron a causa de sus enfermedades en cautiverio. Las penalidades a causa de las enfermedades hicieron mella en muchos de los que fueron liberados: paranoia, desadaptación, depresión, enfermedades respiratorias, urinarias, óseas. Las secuelas del secuestro quedan para siempre:

Estoy en poder de ellos [de los secuestradores de las Farc, CSL]. El terror y la angustia continúan. Me da miedo todo: me da miedo hablar por teléfono, me da miedo que llegue un mensajero con una carta, me da miedo caminar por la calle entre la gente, ir a comer helado a un parque con mis nietas me da terror. Las cosas sencillas de la vida me dan miedo. Sigo secuestrado. (Samper, A., p. 72).

Como bien lo señaló el columnista de izquierda Antonio Caballero, "el secuestro corrompió a las Farc" (Caballero, A., 2014, p. 47) ${ }^{49}$. Pero no solo las corrompió económicamente (millones de millones despilfarrados, gastados en armas, sostenimiento de tropas, incluso para las arcas de comandantes que se fugaron con el dinero), sino las debilitó ética, humana, políticamente. El secuestro los nazificó.

La respuestas que dieron los comandantes de las guerrillas para justificar el secuestro, cambiando esta definición por la de "retenciones forzadas", solo hace parte del cinismo político, la retórica del mal y la descomposición humana que ha acompañado este proceso de violación indolente de derechos humanos. Un secuestrado confronta a su victimario antes de morir y lo hace revelar la verdad:

Día treinta y ocho. Luego de amanecer, el Comandante subió a percatarse del estado de Alejandro Henao y él dijo que no se sentía bien pero que iba a salir adelante. No se dejaría morir. Luego habló de algo postergado:

—¿De qué se trata? -preguntó el guerrillero, y Alejandro repitió:

\footnotetext{
49 “Lo que las corrompió y minó su legitimidad de origen y de propósito fue la utilización del método atroz del secuestro: su recurso inmoral y predilecto para el mantenimiento de su maquinaria de guerra".
} 
—QQué es un secuestro?

- Ah, ¿todavía con eso? Un secuestro es capturar a una persona, privarla de la libertad y mantenerla presionada con maltrato.

— ¿Y una retención? El guerrillero sonrió:

- Retención es mantener en buen estado a alguien por un tiempo determinado, cuidar de él y tratarlo bien. y después de que colabore con la revolución, devolvérselo a sus familiares en perfectas condiciones.

Media hora más tarde subió una guerrillera.

—Alejandro no se mueve. No respira. Está muerto -dijo al regresar, y el jefe guerrillero pareció perder el sentido.

— ¿Por qué me sucede esto a mí? ¿Por qué? ¿Por qué? Tomó la radio y se comunicó con alguien:

- La mercancía sigue dañándose. Negocien con el gobierno la entrega de estos ricos hijueputas. Busquen negociar ya. No tenemos más comida.

El sufrimiento que las Farc y el Eln causaron a más de 16 mil personas secuestradas y sus familias no tiene forma real de repararse. Muchos de los secuestrados fueron asesinados en cautiverio. Se hicieron los pagos extorsivos y en la mayoría de los casos el secuestrado no retornó a su hogar. ¿Dónde están esos cadáveres? ¿Quiénes cometieron los crímenes de estas personas inermes? ¿Qué comandantes o guerrilleros rasos aclararán responsabilidades ante la futura Comisión de la Verdad sobre lo sucedido?

Ingrid Betancourt, quizá el caso más emblemático del secuestro en Colombia por su impacto en medios (estuvo retenida casi 7 años), resumió en su libro de memorias muy bien la dinámica de esta tragedia espantosa:

Escribir este libro me obligó a sumergirme profunda e intensamente en mí misma y en mi pasado, trayendo desde ese fondo abismal, un caudal de emociones desbocadas. (Betancourt, 2010, p. 709). 
Ese "caudal de emociones desbocadas", la tarea de la literatura: "retratar la pura experiencia humana”, en palabras de don Alfonso Reyes (1983, p. 71), es el que analizaremos en Paso a paso de Irene Vasco.

\section{Argumento de Paso a PASO}

Patricia es una adolescente que con sus padres (Beatriz y Enrique) y sus dos hermanos menores (Juan Felipe y Carlos Andrés) han ido de fin de semana a la finca familiar. Cuando bajan del carro para entrar son abordados por hombres encapuchados que los encañonan con armas de largo alcance. En cuestión de breves minutos, los hombres obligan al padre de Patricia a seguirlos hacia una zona rural. La niña, Beatriz y los niños están aterrados, petrificados. Recuperados del shock, Beatriz busca ayuda en un retén militar donde cuenta lo sucedido y regresa a la ciudad para comunicar al resto de la familia la tragedia: el padre ha sido secuestrado.

Los días posteriores al secuestro son percibidos por Patricia como irreales, frenéticos. Su hermana Catalina (quien el día del secuestro se había quedado en casa) apenas si puede sostenerse debido al bloqueo psicológico. Enrique es un industrial reconocido y los medios de prensa han invadido los alrededores de la casa para obtener información. En vista de que la familia -en cabeza del tío Eduardo, hermano de Enrique- ha dado apenas un comunicado convencional, los periodistas amarillistas aprovechan para sacar titulares imprecisos y estrambóticos sobre el secuestro.

En los días siguientes familiares y personas cercanos a los Villegas los visitan y tratan de acompañarlos en la angustia. Nada de esto les gusta a Patricia y Catalina que perciben todo como una pequeña farsa repleta de convenciones sociales. La única visita que ha dejado eco, sobre todo en Patricia, es la de su antiguo profesor Manuel, quien amablemente se ha ofrecido para ayudar a los niños pequeños a no perder el hilo de los estudios, pues ninguno ha ido a clase hace semanas. Carolina cree que tantas visitas son extrañas y empieza a molestar a su hermana con la idea de un romance con Manuel. La madre corta de tajo cualquier posibilidad al respecto y le dice a Patricia que es incorrecto que una adolescente se le ocurra tener acercamientos afectivos con un hombre que ya es adulto.

Los días de pesadilla transcurren sin novedad: Enrique sigue secuestrado y la familia trata de recuperar la cotidianidad sin su presencia. Un ambiente progresivo de desconfianza con todo 
y con todos se apodera del hogar, pues pareciera que nadie quiere ayudar en verdad a retornar a la libertad a Enrique. Además, un ambiente de miedo, de persecución permanente, invade la vida cotidiana de los hijos. Empiezan a llegar las cartas de los secuestradores con las exigencias de dinero, pero la respuesta inmediata que da Beatriz es "Nada", siguiendo la orden de su marido: si era secuestrado, no se pagaría por su rescate. Patricia y Catalina al comienzo pelean con la madre, pero luego entienden el valor de una decisión de ese tipo, pues la entrega del rescate significaría la pérdida del capital familiar, duramente luchado y consolidado por el padre.

Pasan los meses: ni la policía, ni el ejército han podido dar con el paradero de Enrique. Los secuestradores no volvieron a enviar pruebas de supervivencia. Entonces Patricia entra en depresión. Para ella ya hay algo claro: "Mi papá está muerto. Mi papá está muerto. Yo sé que mi papá está muerto”. Es hospitalizada. De pronto surgen anuncios hechos por el gobierno de que la guerrilla tendrá un gesto humanitario y liberará a algunos secuestrados. Para la familia Villegas este es un momento de esperanza...

La promesa resulta falsa. Sin embargo la fe en volver a ver a Enrique no decae. Crece la idolatría por su figura ausente. Catalina se lleva los libros de él para su cuarto y Patricia adopta la ópera -a la que detestaba antes- como su género musical, pues su padre adoraba el bel canto. La religiosidad católica de la abuela (la madre de Enrique) se contagia a toda la familia, incluso a los jóvenes, que no eran particularmente devotos.

Un momento horrible, de gran dolor y tristeza es cuando llaman de Medicina legal, pues ha aparecido un cadáver y creen que es el de Enrique. Beatriz y Eduardo (su cuñado) corren al lugar para hacer la verificación.... Beatriz regresa a casa destrozada y conmovida por lo que vio: el cadáver era de otra persona. Sus hijas la arropan en un gesto de solidaridad y lloran tratando de aliviar el dolor materno.

...Han pasado dos años desde el secuestro y Enrique no ha vuelto a la libertad, ni se sabe si estaba vivo o muerto. Es un día especial porque Catalina celebrará sus 15 años y han preparado una cena. Patricia está a cargo de hacer la torta. Ya es adulta -a la fuerza-. Mientras bate los ingredientes de pronto ve que por la puerta del hogar su padre entra: delgado, pálido, ojeroso. Todos se lanzan a abrazarlo con infinita ternura y felicidad... Pero no. Solo es una fantasía de Patricia. Ella sabe que su padre está muerto. 
Ahora sí en verdad suena el timbre de la puerta. Patricia quiere creer que es el profesor

Manuel, quien le trae flores. Algo ha nacido entre los dos.

\section{Paratextos destacados}

\begin{tabular}{|c|c|}
\hline La carátula & La contracarátula \\
\hline है & 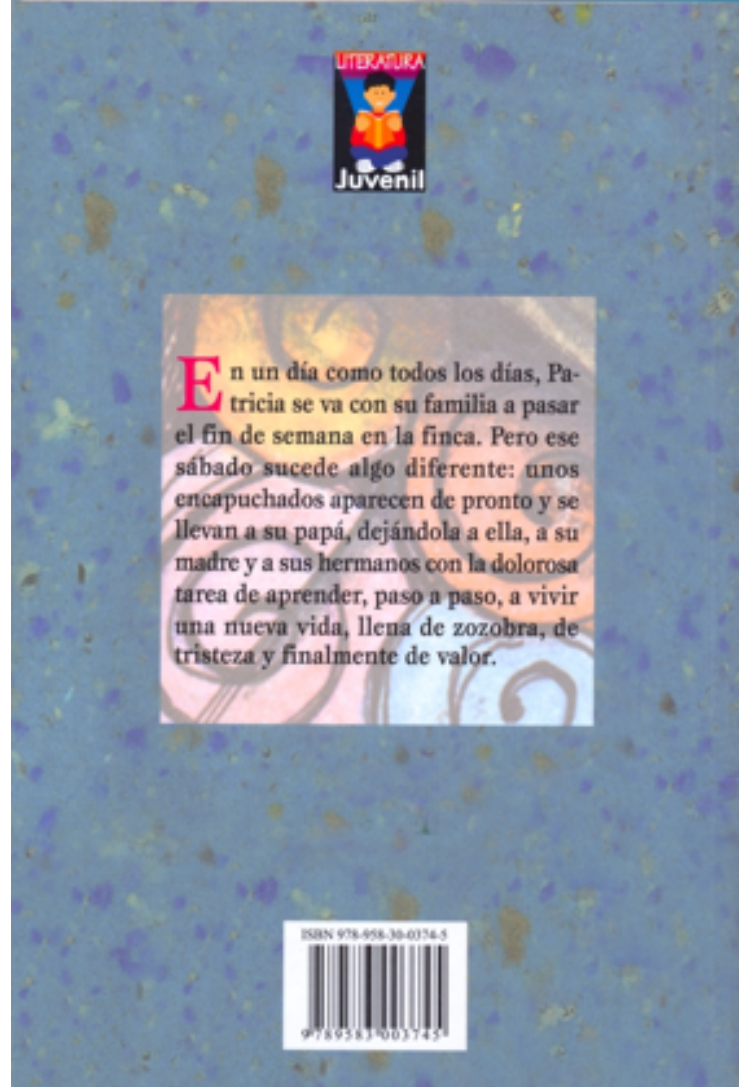 \\
\hline $\begin{array}{l}\text { En cuanto a las marcas escritas resaltan el título } \\
\text { y su potencial anticipación de marcas temáticas. } \\
\text { El subtítulo, con una fuente tipográfica menor, } \\
\text { amplía la información que la contracarátula } \\
\text { ofrece. La oración interjectiva, permite deducir } \\
\text { que la niña que muestra la imagen es } \\
\text { probablemente hija de ese "papá" y que su ruego } \\
\text { tiene que ver con la situación descrita en la } \\
\text { contratapa. La ilustración de Esperanza Vallejo, } \\
\text { en su estilo habitual de collage en el que } \\
\text { combina varias técnicas, destaca a una } \\
\text { adolescente que contesta una llamada al } \\
\text { teléfono. Lo que le dicen del otro lado hace que } \\
\text { ponga su mano en el corazón. El rostro delata } \\
\text { asombro y el principio de la angustia. }\end{array}$ & $\begin{array}{l}\text { En la parte superior el logo establece la } \\
\text { colección a la que pertenece el libro y destaca el } \\
\text { adjetivo "juvenil" con lo que establece el } \\
\text { principal destinatario. La colección también } \\
\text { define que el texto es literario y si bien no } \\
\text { establece que es una novela, el cuadro de la } \\
\text { mitad lo aclarará. El texto central, de } 73 \\
\text { palabras, resume el argumento de la novela y da } \\
\text { pistas sobre los principales hechos que } \\
\text { enfrentará el personaje protagónico, Patricia. El } \\
\text { resumen se centra en generar interés en el lector } \\
\text { a partir del suspenso: ¿qué sucedió?, ¿quiénes } \\
\text { eran los encapuchados?, ¿cómo es esa vida de } \\
\text { "zozobra, tristeza y finalmente de valor"? }\end{array}$ \\
\hline
\end{tabular}




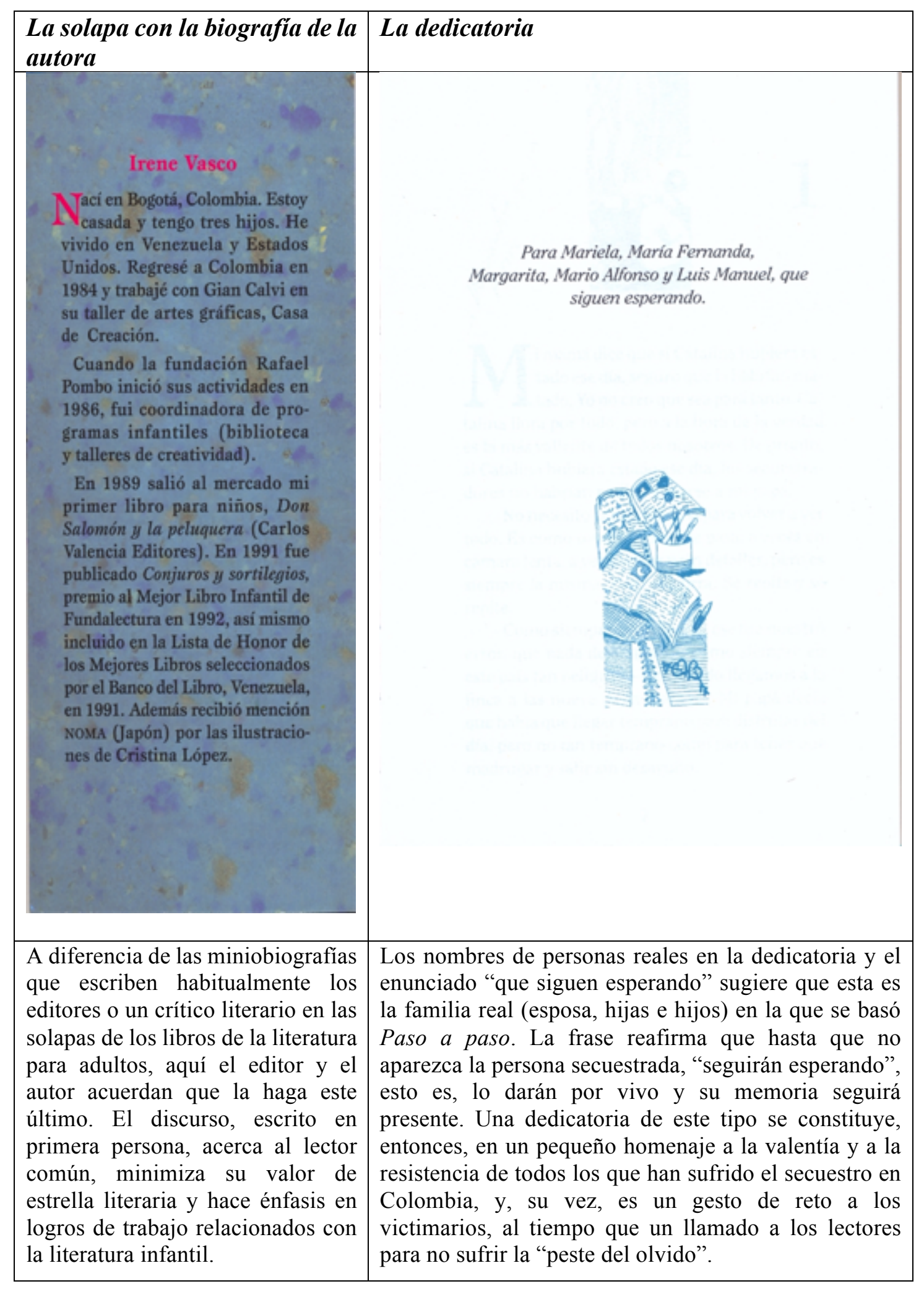




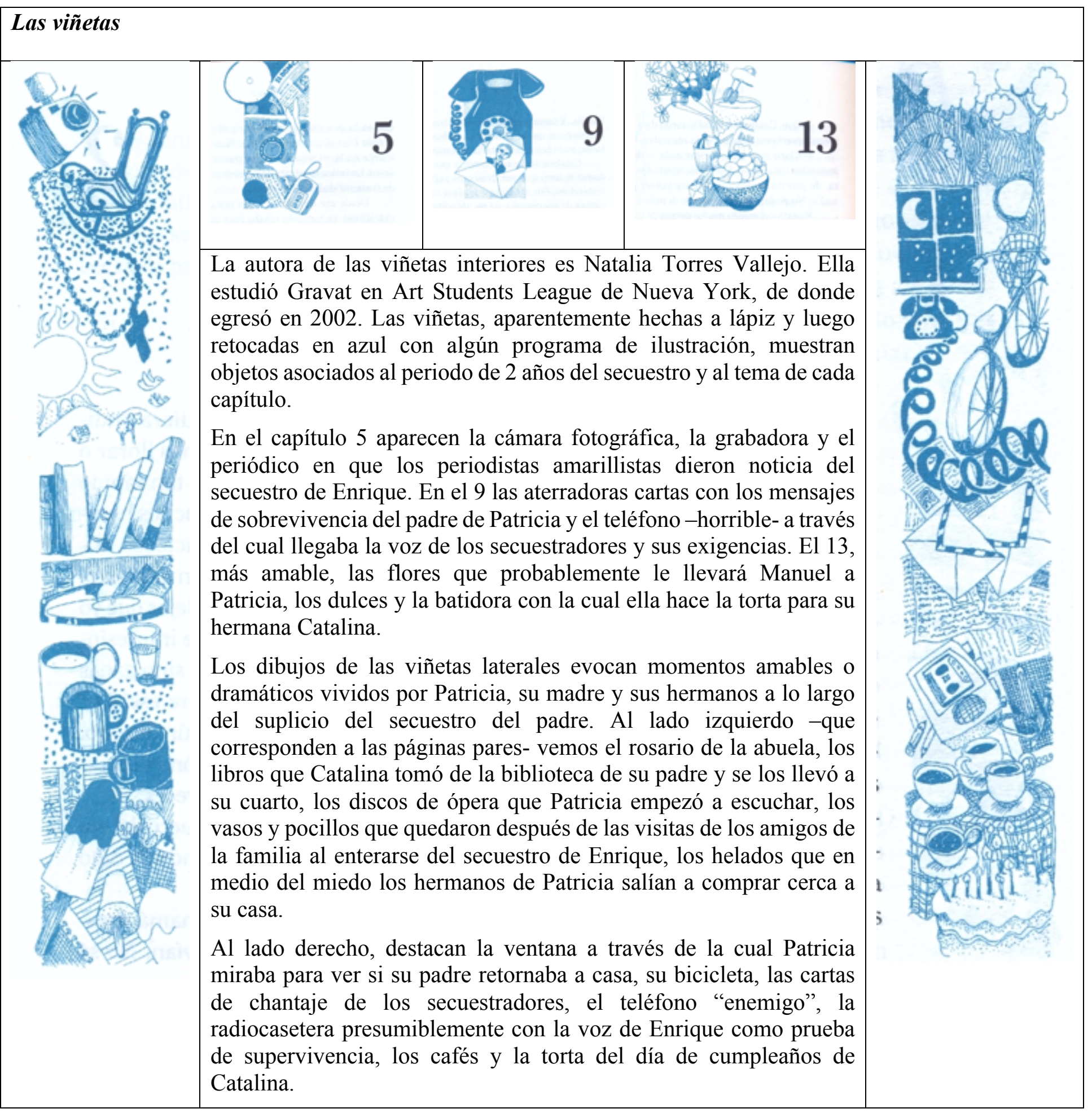




\section{FRAGMENTO DE LA OBRA}

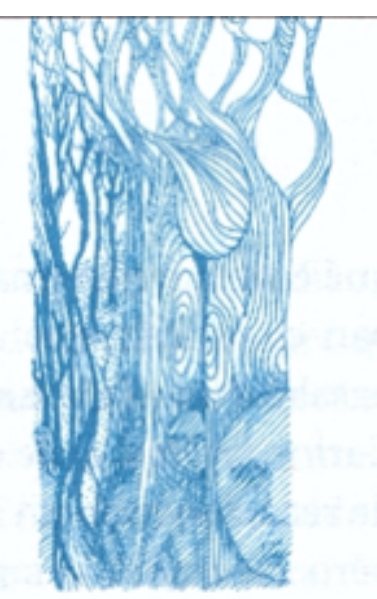

\section{2}

odo fue tan rápido que ni siquiera pudimos despedirnos. Mucho menos llorar o gritar. Pero aunque haya sido tan rápido me acuerdo perfectamente de todo. Muchos hombres encapuchados, tal vez doce, silenciosos, sucios y armados. Sólo me fijé en uno, en el tuerto. Yo nunca había visto de cerquita, ni de lejos que yo recuerde, a un hombre sin ojo. Eso me impresionó mucho. Ni siquiera me dio lástima sino ganas de vomitar. ¡Se veía horrible el hombre ese! Los demás parecían iguales. No hubo ningún disparo.

- Sin duda todos eran de la región - ha explicado mi mamá como un millón de veces.

-Por lo menos debía taparse el hueco del ojo - es lo único que se me ocurre cuando la oigo decir eso.

Se acercaron rápidamente. Mi mamá apretaba a los chiquitos. Ellos no se movían. No sé 


\section{Irene Vasco}

qué estarían imaginando pero se daban cuenta de que algo muy grave pasaba. Juan Felipe se veía asustado. Carlos Andrés, el de doce años, trató de reaccionar en un momento dado, pero mi mamá le tapó la boca. Después ya no trató de hacer nada.

Mi papá me hizo señas para que me quedara quieta. Mi papá y yo podíamos entendernos por señas. Desde que era chiquita, teníamos un código secreto entre los dos. Si mi mamá me regañaba, él me hacía una mueca chistosa. Cuando nació Catalina y yo me moría de los celos, él me arrullaba igual que mi mamá a Catalina y yo dejaba de llorar. Cuando $\mathrm{Ca}$ talina daba quejas de mí, él me regañaba para que ella se contentara pero me hacía un gesto secreto, dándome la razón.

Esa vez entendí inmediatamente lo que mi papá quería decir y me quedé quieta. Todos los días me digo: "Ojalá no le hubiera obedecido. He debido gritar y pelear. Seguro que esos hombres se habrían asustado". 
Tal vez por eso mi mamá dice que si Catalina hubiera estado ese día, seguro que la habrían matado. Catalina no hubiera entendido las señas de mi papá. Y si hubiera entendido, habría desobedecido. Ella es muy rebelde $y$ hace lo primero que le pasa por la cabeza. Catalina no se habría quedado ahí, quieta como una estatua, sólo mirando, como yo, rogando por dentro para que no nos dispararan, para que no nos mataran. Catalina habría hecho algo. Si Catalina hubiera estado ese día, seguro que esos hombres no habrían podido secuestrar a mi papá. 


\section{ANÁLISIS CRÍTICO ${ }^{50}$}

El primer párrafo del capítulo 2 -que hemos citado para identificar las peculiaridades del estilo narrativo- establece inmediatamente el conjunto de convenciones que el lector deberá aceptar si sigue leyendo la novela. Una voz adolescente, en primera persona ${ }^{51}$, instaura la pauta de narración. Sabemos que es una voz femenina porque la información paratextual (ver carátula y contracarátula en la p. 77) así nos lo indica. Patricia-como se llama el personaje protagónico- establece un registro oral adolescente, particular de las clases altas colombianas. Lo prueba la repulsión y cierta distancia en recordar que uno de los secuestradores era un campesino tuerto. Este registro lingüístico sigue la pauta de lo Ong llamó "oralidad secundaria" u "oralidad mediada" (2009, p. 20). La autora del libro ha intercedido para que la voz primaria de la joven quede filtrada y con la coherencia suficiente, y se excluyan de esa voz los dejos o el slang de esta élite social ${ }^{52}$.

Irene Vasco construye un modelo lingüístico y narrativo que cierra la puerta a la voz directa primaria, y en cambio recurre a una narradora cuidada, pero auténtica. Tras bambalinas podemos observar que Vasco ha oído con sumo cuidado a una joven que en realidad existe (lo podemos probar en la Dedicatoria, p. 78), mientras que probablemente ha tomado notas con discreción, en diversas entrevistas, sobre los hechos sucedidos alrededor de la aprehensión forzada del padre. Con ello resaltaríamos que la prosa de Vasco en Paso a paso está comprometida en comunicar a través de la literatura (de la ficcionalización narrativa) una experiencia humana particular, la de los muchachos, jóvenes víctimas que han sufrido los efectos de la guerra en Colombia. La voz cálida, inocente, sincera de Patricia busca generar inmediata empatía con el lector juvenil y en ello se reconoce la gran capacidad de escucha de Vasco para reproducirla - mediada como dijimos- en la escritura de su novela (también es la misma actitud que asume Yolanda Reyes ante las voces de los niños en Los

\footnotetext{
${ }^{50}$ Este análisis de Paso a paso -como el realizado con Era como mi sombra, de Pilar Lozano-, no sigue un patrón comparativo determinado, sino refleja un modo particular de interpretación de la obra.

51 Genette ha llamado a esta voz narrativa "autodiegética", pues es el héroe el que narra el relato. Diégesis designa "todo lo que pertenece a la historia contada como contenido y, en términos más amplios, al mundo que cada relato propone y construye: el espacio y el tiempo, los acontecimientos, los actos, las palabras y los pensamientos de los personajes". (Citado por Charaudeau et al., 2005, p. 500).

${ }_{52}$ Aquí no interesa la voz directa de una persona, como se aprecia en la reproducción del habla de la hija burguesa de un exministro en Colombia X (Castro Caycedo, 1990, p. 28), o el léxico de los jóvenes sicarios de No nacimos pa' semilla (Salazar, 2002, p. 16).
} 
agujeros negros), el cuidado en recoger frases, expresiones, el habla de una joven que en un largo monólogo nos contará su tragedia y la de su familia.

Paso a paso funciona como una crónica periodística ${ }^{53}$ en la que de forma ordenada sin flash backs o recursos narrativos disruptivos se construye el sufrimiento causado por una de las acciones criminales producto del conflicto armado en Colombia: el secuestro. La fortaleza de la novela se centra en la narración intimista de un hecho que tiene bases reales, pero que es ficcionalizado con el ánimo de lograr un impacto más fuerte en el lector y que se basa en un recurso de "Escúchame y dame tu mano, entre tanto". Esta calidez en el pacto narradorlector no es forzada, ni acude a elementos de los géneros populares televisivos como las telenovelas o el reality show. Vasco ancla su fortaleza en la claridad de la voz narrativa de la protagonista, mezclada con un cuidado en los hechos seleccionados para "tocar" la sensibilidad del lector, sin morbo, ni escenas de contexto innecesario.

La novela, dividida en 13 capítulos, tiene una organización sólida basada en la economía narrativa. Si bien los capítulos son numerados y no titulados temáticamente, un lector medianamente competente puede resumir el hilo narrativo, que no se dispersa, como dijimos, y se concentra en resumir dos años de dolor. Vasco no cede al melodrama, en ningún caso, en las escenas afectivas. El llanto, el dolor interior, el sufrimiento del día a día es retratado con frases breves. Las descripciones de los personajes son puntuales ${ }^{54}$ y los adjetivos muy limitados:

Cuando yo tenía siete años, quería ser santa o monja, cualquier de los dos me parecía lo mismo. Me daba miedo cortar con tijeras o con cuchillos y trataba de caminar suavecito porque no quería maltratar a Dios, que estaba en todas partes. (Vasco, 1995, p. 37).

\footnotetext{
${ }^{53}$ La crónica es una ampliación en profundidad (el cómo y el por qué) de una noticia que por su carácter es excepcional. El Manual de redacción de El Tiempo la define como "un texto que desarrolla el aspecto secundario, o de color, de un acontecimiento importante, que generalmente ya ha sido objeto de tratamiento noticioso". La crónica periodística debe reconstruir las "escenas" o momentos claves de un hecho o de un personaje desde el inicio hasta el final sin dejar suposiciones al lector (como sí lo hace el reportaje). El tratamiento informativo y de cotejamiento de fuentes de la crónica -añade el Manual- es el mismo que el de la noticia. (Sánchez Lozano, 2005, p. 2). Recuperado de: http://bit.ly/1PXiVlG.

${ }^{54}$ Irene Vasco en una entrevista a la revista Babar ha dicho al respecto: "No logro vislumbrar imágenes. Quizás por eso en mis textos no hay muchas descripciones. No cuento cómo son las personas, cómo visten, en qué paisajes se mueven”. Recuperado de: http://bit.ly/1mi3CfG.
} 
Hay abiertamente una intención de hacer literatura realista, crítica, testimonial, y de presentar sobre todo al joven lector una experiencia traumática, cuidándose de los extremismos y las escenas crudas a las que nos ha acostumbrado la literatura sobre la guerra. Aquí los hechos exteriores (las visitas de los familiares, el terrible momento cuando la madre deber responder los mensajes de los secuestradores, o asistir a Medicina Legal a comprobar si un cadáver es el de su marido) son los menos. Lo que le interesa es mostrar la interioridad, la intimidad del personaje protagónico y el entorno familiar: la hermana cascarrabias y "lanzada" que dice lo que piensa, los dos hermanos varones de menor edad que pasan de las peleas por minucias al drama de responder las preguntas en el colegio en medio de la ausencia del padre secuestrado, la madre valerosa, la abuela digna que pese a sospechar que a su hijo lo han matado sus captores, abriga la esperanza del retorno.

Paso a paso no tiene intenciones narrativas experimentales. Es un relato "clásico" en su estructura y organización tanto en el manejo del tiempo narrativo, como en el desarrollo de la línea de intensidad del conflicto. Para efectos de explicar algunas escenas de la novela nos hemos valido de un esquema que muestra esos momentos de intensidad narrativa, clasificándolos en picos y bajos. Los picos recogen los momentos más dramáticos de la historia, y los bajos aquellos en los que la protagonista hace análisis o reflexión de lo sucedido, o relata anécdotas intermedias que preparan a un nuevo pico del conflicto (ver esquema 12).

Esquema 12. Intensidad narrativa del conflicto en Paso a paso.

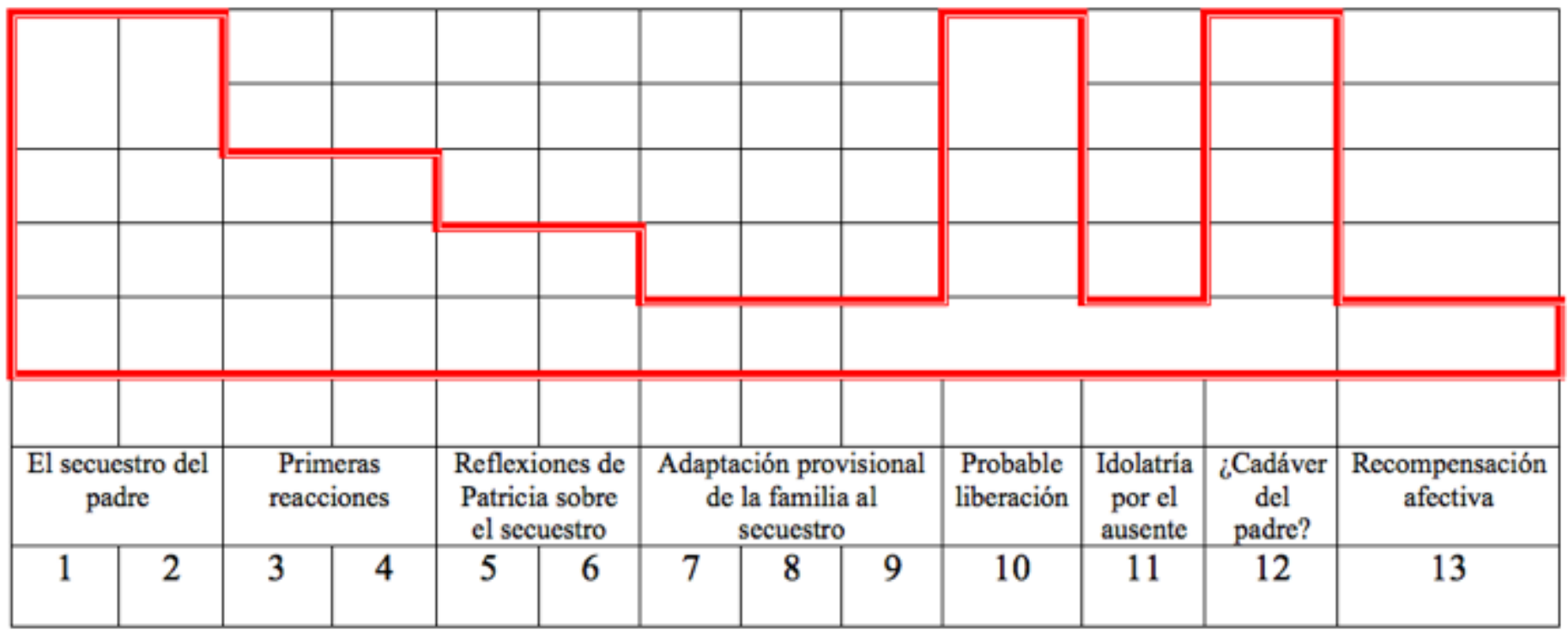


Nota: Elaboración propia.

Como se puede apreciar hay ocho momentos en que gradualmente se organiza el dramatismo para el lector. Los picos son los capítulos 1 al 2 cuando es secuestrado Enrique; el 10 cuando se plantea la posibilidad de que el padre sea liberado por sus secuestradores; y el 12 cuando llega el aviso de Medicina Legal a Beatriz, madre de Patricia, para que acerque a reconocer si un cadáver es el de su marido secuestrado. Los bajos están constituidos por la secuencia de los capítulos 5 y 6 en que Patricia organiza en su mente una explicación coherente de lo que está sucediendo luego del secuestro; en los capítulos 7 a 9 se muestra la forzosa adaptación de la familia a la nueva rutina de vida sin el padre, que sigue secuestrado; el 11 resume la añoranza por el padre que ahora es idolatrado y la resolución de sus hijos que quieren ser como él, apropiarse de sus enseñanzas, mientras asumen sus gustos y pasiones; y el capítulo 13 en que Patricia descubrirá la dolorosa verdad y a su vez se presta para asumir una nueva aventura en la vida, que anuncia su madurez.

Vasco organiza el dramatismo en función de la capacidad de capturar la atención del lector, desde luego, pero fundamentalmente lo hace para que este comprenda el estado anímico de Patricia, que va del terror inicial del momento del secuestro (capítulo 1), a la ensoñación que tiene con la probable aparición de su padre en el cumpleaños de su hermana Catalina (capítulo 13). Una escena brillante, por la riqueza de sus matices narrativas, es la del capítulo 12 cuando la madre, Beatriz, debe asistir con su cuñado a la Dirección Nacional de Inspección Criminal y reconocer si un cadáver es su esposo. En vista de que el texto está narrado por Patricia (que funciona como narrador interno, y solo sabemos lo que ella ve y siente), la autora de la novela acude al discurso directo libre ${ }^{55}$ (Marín, 2009, p. 72) para presentar un hecho que toca a la madre:

—Llama a la oficina de tu tío Eduardo y dile que paso a buscarlo en diez minutos. Encontraron un cuerpo y quieren confirmar si es el de Enrique. No le digas nada a nadie. Yo te aviso apenas sepa algo -y se fue temblorosa. (Vasco, 1997, p. 67).

\footnotetext{
${ }^{55}$ La lingüista Marta Marín define así el concepto de discurso directo libre: "En Lingüística del discurso y Teoría de la enunciación, representación de los enunciados de otra persona sin modificarlos; no relata lo que el otro enuncia, sino que finge reproducir los enunciados de otro. Aparece con frecuencia insertado dentro de la narración en forma de diálogo".
} 
La tensión se apodera del lector pues necesita saber cuanto antes si es verdad o no que el cadáver es el del padre de Patricia. Las páginas 67 y 68 se leen con gran rapidez. Viene, entonces, una descripción desoladora cuando la madre retorna a casa:

Mi mamá se veía descompuesta, pálida, despeinada. Se veía mucho peor que el día del secuestro, que todos los otros días. No lloraba, no hablaba. El tío Eduardo la sostenía y la acompañaba despacio. Yo corrí a abrazarla, preguntando qué había pasado. Mi mamá me apartó y me dijo que no la tocara. El tío Eduardo me hizo señas de que me tranquilizara y llevó a mi mamá hasta su habitación. Cerró la puerta y me dijo en voz baja: "No era Enrique”. (Vasco, 1995, p. 69).

La escena con la que se cierra el capítulo 12 tiene un matiz religioso católico: las tres mujeres (la madre y las dos hijas) se abrazan llorando en un gesto de solidaridad femenino profundo, que en mucho reafirma la vigencia del mensaje de La Piedad, de Miguel Ángel.

Imagen 6. La Piedad, de Miguel Angel.

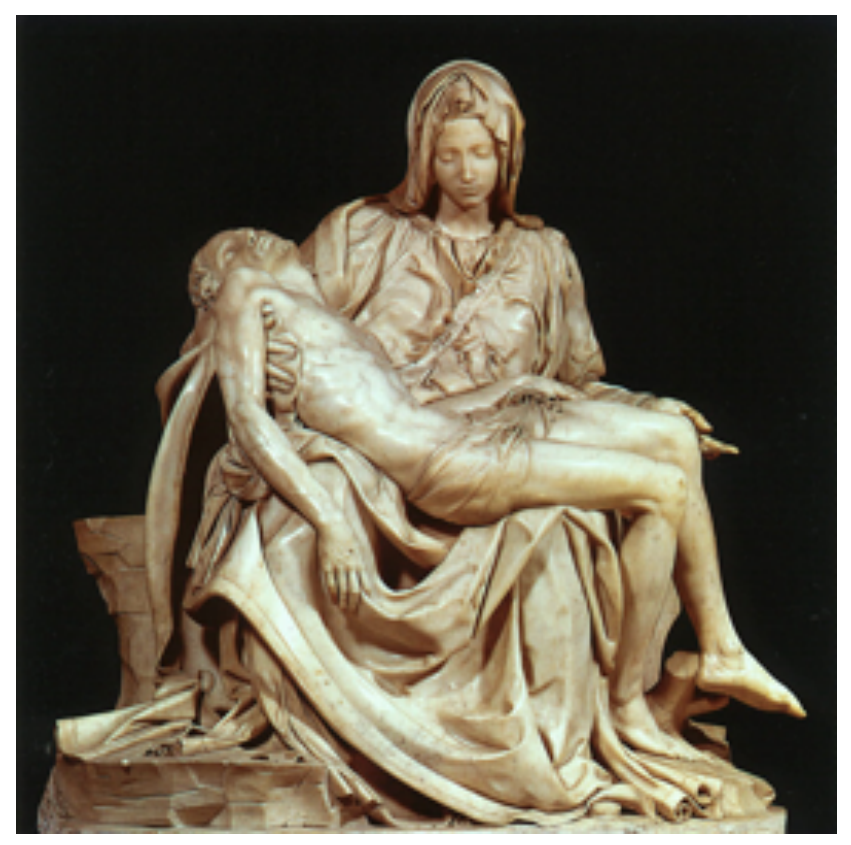

Nota: Recuperada de: http://bit.ly/1ojbZt3

Dos aspectos que resaltan de Paso a paso se relacionan:

- Con el manejo de los hechos extratextuales y del lector implícito que hace la autora. 
- Con la presencia del profesor Manuel, que pese a que solo aparece en los capítulos 6, 7, 9 y 13, y tiene el carácter de discreta sombra en la trama de la novela, cumple un papel fundamental: el de servir de enlace entre la Patricia adolescente y la Patricia que ingresa a la madurez.

Los conocimientos sobre las implicaciones de un secuestro no son extrañas para un niño o adolescente, al menos de la generación en que se publicó el libro (1995) ${ }^{56}$. Como se ha señalado en el Contexto histórico, este fue el periodo en que más plagios se cometieron (ver p. 67), la mayoría por parte de las guerrillas de las Farc y el Eln ${ }^{57}$. La degradación a la que llegó el conflicto armado en Colombia -entre los muchos testimonios de horror que hay para comprobarlo- se demuestra con las cifras vergonzosas de secuestrados en cinco años. ¿Pero cómo trabaja Irene Vasco con esta información extratextual y con qué fines? En el pacto autor-lector tiene que haber un conjunto de saberes previos ("Enciclopedia" la denomina Umberto Eco $)^{58}$ de parte de este último para comprender y relacionar con la realidad lo que aquel le cuenta, a riesgo de que si no lo hace, no se cumplirá el contrato de emociones y empatías que supone un texto literario.

Vasco aprovecha las estrategias que tiene el lector implícito (Iser, 1987, p. 176; Chambers, 2008, p. 81) y le pide ponerlas en escena para relacionarse con el texto. En el capítulo 9, cuando llega la prueba de supervivencia a la casa de Patricia, la mamá de ella al ver la foto del secuestrado afirma: "Enrique se les va a morir" (Vasco, 1995, p. 50). Un niño que no tenga enciclopedia suficiente podría preguntar: “¿por qué?”. Los largos secuestros (véase GMH, 2013, p. 300) afectaban de modo irreversible la salud física y psicológica del retenido, pero esto no tendría que saberlo un niño -incluso un joven de hoy- a menos de que haya visto esta información en medios de prensa escrita, radio o televisión. El diálogo realidad ficcional - realidad real se construye con todos estos aportes de significado tanto del autor como del

\footnotetext{
${ }^{56}$ Vasco ha aclarado en la entrevista a la revista Babar: "Paso a paso fue publicado en 1995 pero los hechos en los que me basé sucedieron en 1988. En ese tiempo los colombianos vivimos las transformaciones de un país que consolidó su economía alrededor del narcotráfico. Cuando escribí Paso a paso ya se vislumbraba este entorno pero la vida cotidiana ocultaba, hasta cierto punto, la profunda crisis social que se iba adueñando de cada palmo de Colombia". Recuperado de: http://bit.ly/1mi3CfG.

${ }^{57}$ El Grupo de Memoria Histórica (GMH), en ¡Basta ya!, recoge una estadística de Cifras y Conceptos y señala que entre 1996 y 2000 hubo 16.000 secuestros. (GMH, 2013, p. 65). Recuperado de: http://bit.ly/1S5aKKi.

58 "La noción de enciclopedia es más que la presencia de todas las opiniones comúnmente compartidas en un momento histórico sobre los referentes de una palabra. Implica las definiciones que una cultura proporciona de todas sus unidades de contenido". (Eco, 1981, p. 24).
} 
lector implícito. Vasco no va más allá y es parca, reticente a crear frisos descriptivos de contexto o a poner en boca de los personajes discursos explicativos sobre el mecanismo de funcionamiento del secuestro extorsivo. Trabaja con los saberes previos del lector, por muy limitados que sean estos, y lo que le interesa es mostrar el estado anímico de los personajes desde afuera. Por eso acude puntualmente (no son más de diez veces a lo largo de las 80 páginas del libro) al discurso directo libre. Beatriz le responde a su hija Patricia cuando esta la insta a pagar el rescate:

- Lo último que voy hacer es dejarme chantajear. Su papá y yo estamos de acuerdo en no dar ni un peso en caso de secuestro. Si yo fuera la secuestrada, Enrique tampoco había pagado. Esa gente que paga rapidito es la culpable que los secuestros se haya convertido en un negocio tan bueno. Yo no voy a contribuir a que secuestren a otros (Vasco, 1995, p. 52).

Tampoco Vasco acude a las cifras de secuestros o a los titulares de prensa para dar una dimensión del secuestro como hecho cruel. No hace realismo propagandístico. Su viraje está en hacer un retrato del profundo daño moral, afectivo, que produce el secuestro en una familia. La literatura está antes que el documento ${ }^{59}$. Esto es un reto -y enorme- para un narrador de literatura infantil y juvenil porque limita su fortín de recursos. Allí está la experticia de Vasco que con poco logra mucho y en ello radica uno de sus aportes al género de la novela juvenil en Colombia.

Igualmente la autora, implícitamente, asume una posición ética firme: no dará visibilidad a los victimarios sino a las víctimas. Es la memoria de las víctimas la que se debe mostrar. En ese sentido se alinea en la posición que el filósofo español Reyes Mate (2011) ha reclamado:

La batalla de la memoria la tenían perdida las víctimas desde el momento en que asociamos memoria a memoria voluntaria. La memoria quedaba así a merced del vencedor (el victimario, $C S L$ ) que era el único que tenía conocimiento comentado de lo que ocurrió. Así hasta que Benjamin detecta un extraño elemento subversivo -"el ahora"-, es decir, ese momento no amortizado del pasado vencido que clama justicia, ese momento de vida oculto en la ruinas que aparecen muertas o naturalizadas. Ese "ahora" del pasado puede asaltarnos sin

\footnotetext{
${ }^{59}$ Un hecho contrario lo veremos en el análisis de la obra de Pilar Lozano, Era como mi sombra.
} 
pedir permiso y puede así derrotar las estrategias del olvido. Si es verdad que el vencido no está a salvo mientras el vencedor ande suelto porque puede añadir a la muerte física la hermenéutica, tampoco puede descansar tranquilo mientras haya una huella, así sea mínima, de lo que en realidad ocurrió. (p. 291).

En el texto escrito de la novela no se dice explícitamente quiénes son los secuestradores del papá de Patricia ${ }^{60}$ y se deja al lector (de acuerdo con la "competencia enciclopédica" citada) que realice la inferencia. En cambio en el texto visual sí se aporta información que puede ser importante para el lector atento. Los paratextos - una viñeta que acompaña al capítulo 2muestra que posiblemente los captores son guerrilleros. Obsérvese el cuidado con que la ilustradora (Rocío Parra) presenta a los secuestradores como sombras en medio de la selva. Hombres sin rostro, en un ambiente áspero, oscuro, lejos de las ciudades.

\section{Imagen 7. Rostro de un guerrillero}

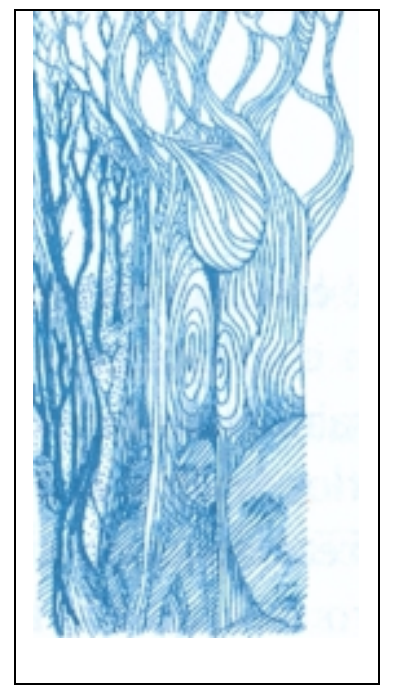

Nota: Adaptado de Vasco I. (1997). Paso a paso. Bogotá: Panamericana.

Aparte de esta viñeta y de la descripción del secuestro en los capítulos 1 y 2, Vasco no concede espacio a las escenas de violencia, preferidas en la publicidad de los victimarios para enviar el mensaje de lo que sufrirán las personas que no cedan a sus deseos. Al respecto Vasco ha dicho:

\footnotetext{
${ }^{60}$ Con altas probabilidades, de acuerdo con la información que hemos aportado en el Contexto histórico (p. 6977), y por el modus operandi, fue un comando de la guerrilla de las Farc o el Eln el que realizó el secuestro.
} 
La narrativa alrededor de la violencia se ha banalizado con el propósito subyacente de ocultar. El Estado y los medios utilizan la violencia como lema conveniente y efectista de cuanta campaña publicitaria o propaganda requiera la compasión del público, con cualquier propósito. La imagen de la violencia así transmitida por los medios, bombardea a niños, jóvenes y adultos a toda hora y en todo lugar. Tal sobreexposición mediática termina por insensibilizar a la sociedad haciéndola creer que toda violencia, incluyendo la verdadera violencia, es ficción. (Vasco, 2013, p. 9).

El segundo aspecto -la presencia de fondo del profesor Manuel y su amistad con Patriciatiene que ver con lo que una investigadora en literatura infantil colombiana (González, 2013) ha llamado motivo recurrente en las novelas juveniles latinoamericanas que tienen como temática la violencia:

Para auxiliar al niño-joven a encontrar su verdad (...) el ayudante o mediador de la historia es el maestro del niño protagonista. Es este también quien le da las claves para armar el rompecabezas de la historia. (...). Suele ser un personaje que está más allá del bien y del mal, a veces un poco misterioso en su procedencia y creencias, pero eso sí, acompaña en todo el proceso al personaje principal. (p. 14).

En efecto, el profesor Manuel representa para Patricia el puente de tránsito entre la juventud y el ingreso a la adultez reflexionada. Ese paso a paso es descrito puntualmente en los capítulos 6, 7, 9 y 13. Al comienzo Manuel simplemente es el tutor de los dos hermanos de Patricia (Carlos Andrés y Juan Felipe), pero progresivamente vemos crecer su influencia dentro de la familia cuando se convierte en amigo de Patricia. Esto ocasiona los celos de Catalina (hermana de Patricia) y la acusación de que profesor y alumna son "novios". Luego del regaño de la madre a Patricia ${ }^{61}$ por lo inconveniente de esta relación, Manuel sigue normal en sus funciones de profesor de los niños pequeños. Sin embargo siempre lo vemos como una sombra bondadosa, y aunque no se cuenta en la novela, desde la perspectiva del lector

\footnotetext{
61 "No se te olvide que ya pasa de los 30 años, que es un profesional y que tiene una novia formal, que también es profesora en el colegio. Tú eres una niñita y él solo va a fijarse en ti como una amiga. Tienes que salir con muchachos de tu edad". (Vasco, 1995 p. 39).
} 
(sobre todo yo diría la lectora femenina) seguro que se hizo presente en los momentos más críticos del sufrimiento de Patricia (capítulos 10 y 12).

Vemos reaparecer a Manuel en el capítulo final como símbolo de la esperanza:

Prefiero cambiar la película. Veo a Manuel, el profesor, en la puerta de la cocina. Llega recién peinado, con corbata y saco. Trae un ramo de rosas en la mano. Sonríe y me entrega las rosas. Nada más. Por ahora prefiero imaginar hasta ahí. No sé, es posible que de tanto imaginar, de tanto querer, de tanto rezar, algún día suceda. Yo creo que sí. (Vasco, 1995, p. 77).

La narradora, Patricia, constituye desde la perspectiva que hemos expuesto en esta sección de la investigación, uno de los personajes más sólidos de la literatura juvenil colombiana y latinoamericana. Definida en rasgos expuestos a través de un registro fresco, sincero, directo, su voz de víctima resume el drama de muchos - cerca de 27 mil familias- que sufrieron el lastre del secuestro entre 1970 y 2002. Si bien es una chica perteneciente a la clase alta (es hija de un industrial reconocido), esto no la aleja de reconocerse como parte de una guerra que traumatizó a la sociedad colombiana. Los duros momentos emocionales que debe atravesar (“Mi papá está muerto. Mi papá está muerto. Yo sé que mi papá está muerto”, cap. 10) no la desbancan de la dignidad, el coraje, que ha ganado en medio del sufrimiento. Contra la desesperanza, exhibe el humor (" a mis amigas les encanta que les digan el futuro y van a que les lean la mano o las cartas. A mí eso me da pavor. Si a uno le va pasar algo, es mejor que sea de sorpresa y cosa por cosa”); contra la bajeza de los secuestradores, opone la reflexión fina (“Aprendí de mi mamá a mantener una posición firme, pasara lo que pasara. Espero que esa lección no se me olvide nunca"); contra la demencia de la realidad, exalta la coherencia ("Yo no hago tratos ni apuestas con la vida. Antes hacía promesas que cumplía hasta el último minuto. Ya no. Ahora rezo, pero no para pedir cosas”).

Los dos años del secuestro de su padre logran que pase de ser una niña introvertida, centrada en un universo de vida limitado propio de entorno burgués, y amplíe horizontes y crezca: el conocimiento del país (de su crueldad y de lo mejor de él), la formación psíquica interior, la solidaridad al acompañar a su mamá y a sus hermanos en los momentos más difíciles, el riesgo que implica enamorarse de un hombre mayor, su profesor. La muerte -el probable asesinato de su padre- no la llevan ni a la locura, ni al suicidio. Logra levantar cabeza en 
medio de la tormenta y mantenerse firme. Dulce, amorosa, ingenua, con esperanza en medio del desespero y la derrota: todo un ejemplo de lo que históricamente ha sido la mujer colombiana.

Con Paso a paso (1995) Irene Vasco hace varios aportes a la narrativa colombiana que es necesario resaltar veinte años después de publicada la novela. Quisiera destacar tres. El primero tiene que ver con introducir un elemento inédito en la literatura sobre la violencia: el personaje adolescente, femenino, de clase alta que sufre -ella y su familia- en carne propia el drama del secuestro. Como lo señalé en una reseña recién publicada la novela:

Patricia es hija de un industrial y el ambiente es burgués, pero el dolor de esta adolescente podría ser igual al de la hija de un sindicalista o un profesor desaparecidos. El llanto es el mismo. Parafraseando a Brecht: el visitante trágico no me interesó hasta que me visitó a mí. (Sánchez Lozano, 1996, p. 20)

El segundo aspecto renovador en la novela de Vasco es que el realismo que adopta (el fragmento de realidad que organiza coherentemente en su obra) no es mimético, ni de denuncia. Acepta el desafío de hacer ficción de base histórica sobre la violencia contemporánea en Colombia pero renuncia a la toma de partido. Hay una distancia clara con cualquier interés de exponer consignas políticas (como lo propusieron las obras del realismo socialista) y, en cambio, sí se refleja un realismo intimista, una subjetividad cuidada expuesta con una prosa puntual y elegante. Le interesa exponer el sufrimiento, mas sin hacer gala de morbo o cursilería. A este realismo, Ángel Rama (2006) lo denominó realismo crítico ${ }^{62}$ porque desborda las intenciones del realismo social tipo Zola y se enfoca en criticar de forma mediada la sociedad a la cual retrata y busca desentrañar. Esa mediación pasa por un uso particular del lenguaje literario y por reconceptualizar los fines de la novela en la sociedad de masas, que es constituirse en contestataria del poder.

Lo que es nuevo en estas obras (...) es la rebelión contra todas las formas del poder, su reconocimiento de que se extiende a las más variadas manifestaciones de la vida social y de su cultura, afectando tanto la relaciones sexuales como las estructuras lingüísticas, la organización aparentemente racional del discurso

\footnotetext{
${ }^{62}$ Sobre todo en el ensayo dedicado a El pozo de Juan Carlos Onetti y en Los contestatarios del poder.
} 
como las formas legales de la explotación económica, la estructura familiar como el sistema de clases (p. 110).

Y finalmente quisiera señalar el tercer logro de Vasco, y este referido a ella como intelectual. Su postura ética como escritora (al igual que Pilar Lozano en Era como mi sombra) se resume en un principio: no callar. Contra el olvido, contra la dispersión, contra la indiferencia, contra el poder, ella opone la memoria. La memoria de las víctimas. 


\section{Capítulo 3}

\section{FicCIONALIZACIÓN DEL RECLUTAMIENTO ILÍCITO DE MENORES EN ERA COMO MI SOMBRA de Pilar lozano}


FICHA DEL LIBRO

\begin{tabular}{|c|c|c|c|c|}
\hline Título & \multicolumn{4}{|c|}{ Era como mi sombra } \\
\hline Autora & \multicolumn{2}{|c|}{ Pilar Lozano } & $\begin{array}{l}\text { Imagen de } \\
\text { carátula }\end{array}$ & Antonio Galante \\
\hline Editorial & \multicolumn{4}{|c|}{ Ediciones SM } \\
\hline \multicolumn{2}{|c|}{ Fecha de publicación } & 2016 & Paginaje & 88 páginas \\
\hline Género & \multicolumn{4}{|c|}{ Novela juvenil, realismo histórico } \\
\hline \multicolumn{4}{|c|}{ Eje temático articulado con el conflicto armado } & $\begin{array}{l}\text { Reclutamiento ilícito de } \\
\text { menores }\end{array}$ \\
\hline
\end{tabular}

\section{BIOGRAFÍA DE LA AUTORA}

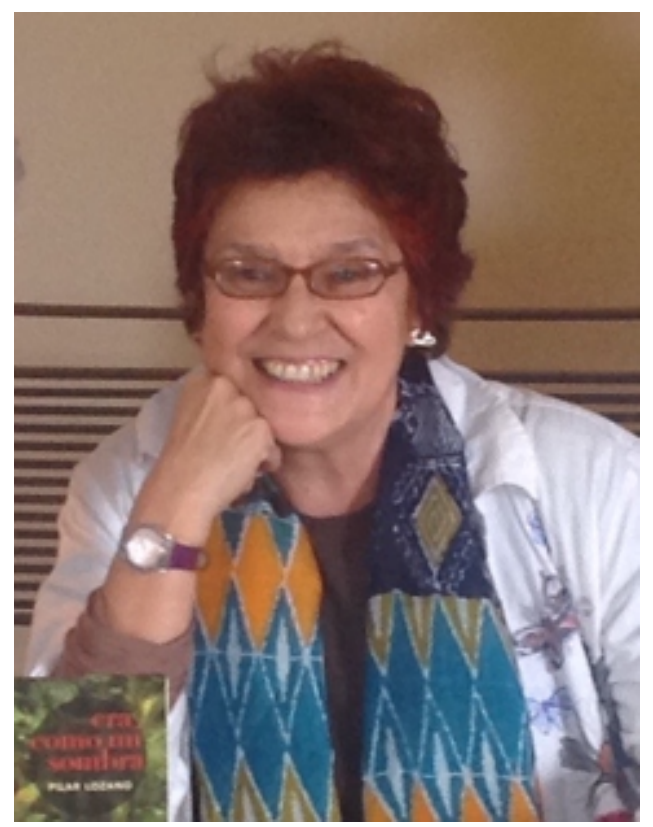

Pilar Lozano. (Bogotá, 1951). Terminó su secundaria en el Colegio Nuestra Señora del Pilar de Bogotá e hizo estudios de de Comunicación Social en la Universidad Javeriana. Fue militante del grupo izquierdista Moir (Movimiento Obrero Independiente Revolucionario) durante los años 70, donde hizo sus primeros "pinitos" como periodista. Desde entonces su pasión como comunicadora no desfalleció y durante 22 años trabajó para diferentes medios de radio (Caracol, Noticiero Todelar, Deutsche Welle de Alemania), prensa (Cromos, Diners, 
Revista Mujer, El Espacio, El Tiempo) y televisión (Noticiero Promec, Contrapunto, y en el programa de documentales Vamos a ver).

Fue corresponsal en Colombia del reconocido diario El País de España para el que cubrió el asalto al Palacio de Justicia en 1985, el proceso de paz con el M-19 en 1990, y los fallidos diálogos en el Caguán con las Farc a finales de los años 90 del siglo pasado. Ha ganado dos veces el Premio Simón Bolívar de Periodismo: en 1979, en la categoría de crónica escrita por “Puntas de Colombia” (revista Diners) y en 1981, en la categoría de crónica radial por la serie sobre sectas religiosas en el Programa Las reporteras de Caracol.

Lozano se ha caracterizado por hacer un periodismo investigativo, con énfasis en el reconocimiento y denuncia de los problemas sociales, sobre todo de los campesinos, los indígenas y la población afro. Ha recorrido el país de punta a punta y conoce casi todos los 1.100 municipios que tiene Colombia ${ }^{63}$, bajo el criterio de que "el periodismo tiene la obligación de darle elementos al lector para que se forme un criterio sobre la realidad". Este fervor por divulgar el "otro país", el país profundo, tuvo su reconocimiento al obtener en 1982 el Premio Julio Daniel Chaparro de mejor crónica, sobre los entonces territorios nacionales, por la serie "La ruta de La vorágine".

Su ingreso a la literatura infantil tiene mucho que ver con una consigna: "Lo que busco es contar un país que no conocemos aún, de un territorio que es nuestro y que ignoramos". Sus libros de literatura para niños reflejan su interés en contarles cómo es ese país inédito. De esa idea es producto Colombia, mi abuelo y yo, un libro en el que muestra la belleza de la geografía nacional (1994), Turbel, el viento que se disfrazó de brisa (2001), una historia de amistad en los campos colombianos, y el dramático Era como mi sombra (2015), dedicado a los niños reclutados como soldados por los grupos armados ilegales.

Pilar Lozano también ha escrito libros informativos para niños en los que ha resaltado los aportes en la construcción de nación por parte de médicos (Manuel Uribe Ángel: el médico y geógrafo que amó a su país, 1997), ingenieros (José María Villa: el violinista de los puentes colgantes, 1998) y pilotos que llevaron sus aviones a sitios inhóspitos del país (Los que abrieron caminos en el cielo, 2002). Otros de sus trabajos documentales más destacados hasta

\footnotetext{
${ }^{63}$ A la pregunta de cuál es la ciudad colombiana que más le cautiva, responde: "Mitú, en el Vaupés, porque en ella se junta lo que más amo: selva y río".
} 
el momento son Así vivo yo (2011), un retrato de la vida cotidiana de once niños de zonas apartadas de Colombia, y la crónica dedicada a la historia de Villavicencio, incluida en Los días del asombro (2015).

Pilar Lozano dice en una entrevista: "La literatura infantil me ha servido para equilibrar el alma. Ver toda esa realidad tan cruel en Colombia a través de mi ejercicio periodístico hace que la literatura para niños me reconforte de tantas penas de las que he sido testigo como reportera". En otra entrevista concluye de modo radical: "Escribo para niños simplemente porque me hace feliz".

Infatigable, Pilar es promotora de lectura e integrante de Relata, la Red de Escritura Creativa, que patrocina el Ministerio de Cultura de Colombia ${ }^{64}$.

\section{CONTEXTO HistóRICO}

Imagen 8. Niña guerrillera. San Vicente del Caguán, Caquetá, 2000.

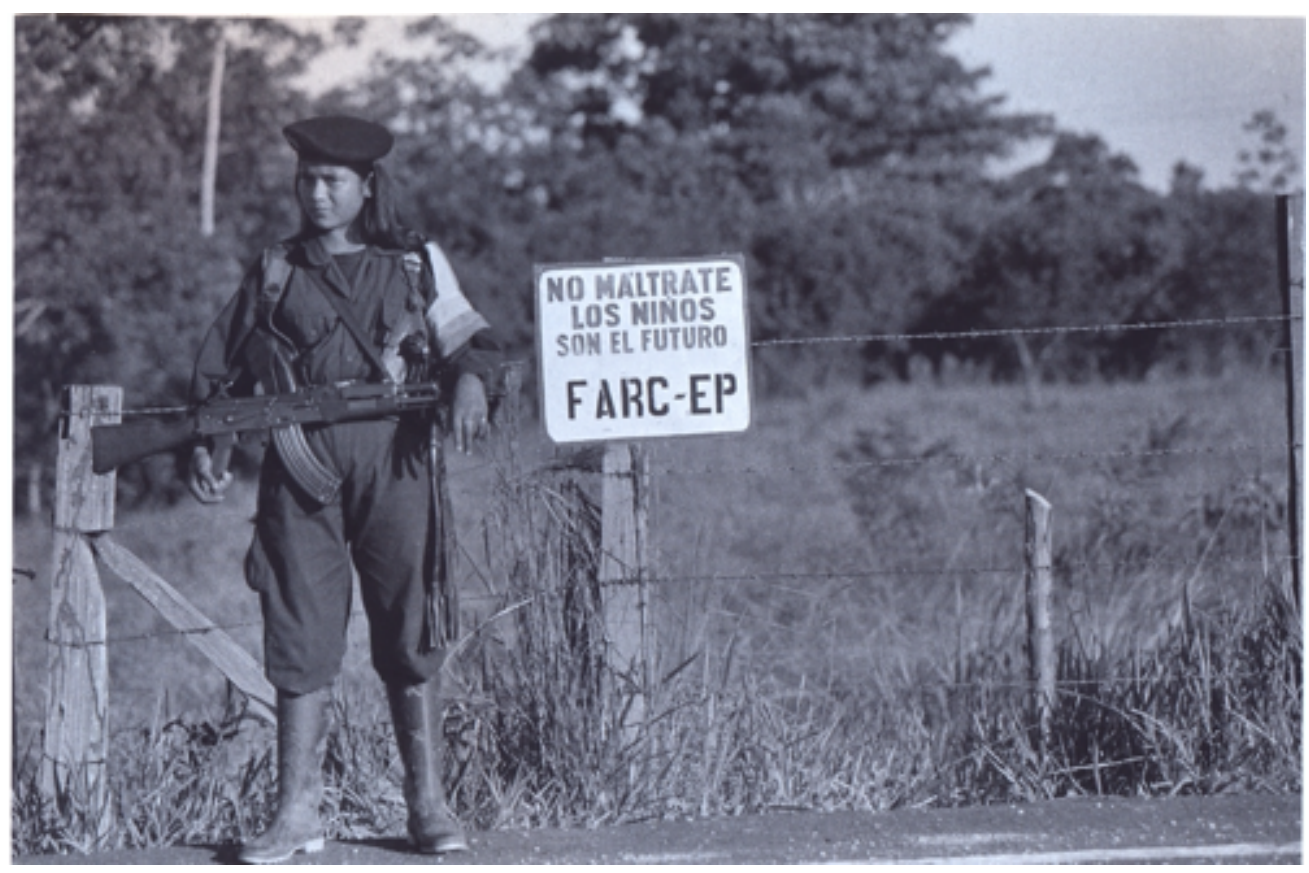

Nota: Tomada de Abad Colorado, J. (fotógrafo). (2015). Mirar de la vida profunda. Bogotá: Planeta.

\footnotetext{
${ }^{64}$ Este perfil biográfico se elaboró con base en la información que me dio Pilar Lozano en una entrevista personal y la localizada en los siguientes sitios web: http://bit.ly/1TiIKIE, http://bit.ly/1U3aMSG, http://bit.ly/1ObEugY
} 
No deja de ser irónico observar la foto de la niña guerrillera tomada por el reconocido fotorreportero Jesús Abad Colorado durante el periodo de diálogo entre el gobierno Pastrana y las Farc. Es una menor de edad -no pasa de los 15 años- con un fusil Galil, al lado de un letrero público que contiene una consigna -"No maltrate los niños. Son el futuro"- de intenciones políticamente correctas. La ironía radica en que el texto del aviso contradice, absolutamente, lo que muestra la imagen: si un grupo maltrató de modo brutal a los niños fueron las Farc. Para ellos -como para lo paramilitares- los niños no fueron el futuro, sino el presente de la guerra: usaron y abusaron de ellos sin ningún tipo de piedad o contemplación violando los tratados y leyes que prohíben explícitamente el reclutamiento de menores para fines militares ${ }^{65}$.

El reclutamiento ilícito de menores ${ }^{66}$ es contemplado como delito de lesa humanidad por la Corte Penal Internacional, pero cierta condescendencia histórica ("siempre ha habido niños en la guerra" ${ }^{67}$ hizo que se pasara por alto la gravedad del delito -la inmoralidad radical del hecho- y aún hoy persiste la idea que si hubo niños en la guerra fue porque en parte quisieron. De hecho estas fotos de niños guerrilleros hechas por Abad Colorado probablemente suscitaron opiniones de rechazo de parte de los defensores de derechos humanos, pero la opinión pública, anestesiada por la sinsalida de la Zona de distensión del Caguán en 2000 y la urgente petición de mano fuerte contra la subversión que llegaría con el primer gobierno de Uribe Vélez, no reaccionó de manera enérgica ante la presencia de niños, niñas y adolescentes en los grupos armados.

\footnotetext{
${ }^{65}$ Convención sobre los Derechos del niño (1990), Estatuto de Roma de la Corte Penal Internacional (2002), Código Penal Colombiano (2000) Ley de Infancia y Adolescencia (2006).

66 "El reclutamiento ilícito constituye un delito en el que los actores armados, con ocasión y en desarrollo del conflicto armado, reclutan civiles menores de dieciocho años obligándolos a participar directa o indirecta en las hostilidades o en acciones armadas". (GMH, 2013, p. 84).

${ }^{67}$ Se cita con frecuenta el caso de Pedro Pascasio Martínez en las guerras de Independencia de comienzos del siglo XIX, y el de más de mil niños reclutados durante la Guerra de los Mil Días (1899-1902). Guerrilleros como el Mono Jojoy y su hermano Granobles en las Farc, y Gabino en el Eln, desde niños ya pertenecían a los grupos alzados en armas. (Cfs. Pachón, 2009, p. 7).
} 
Imagen 9. Niños pertenecientes a un batallón de soldados durante la Guerra de los Mil Días.

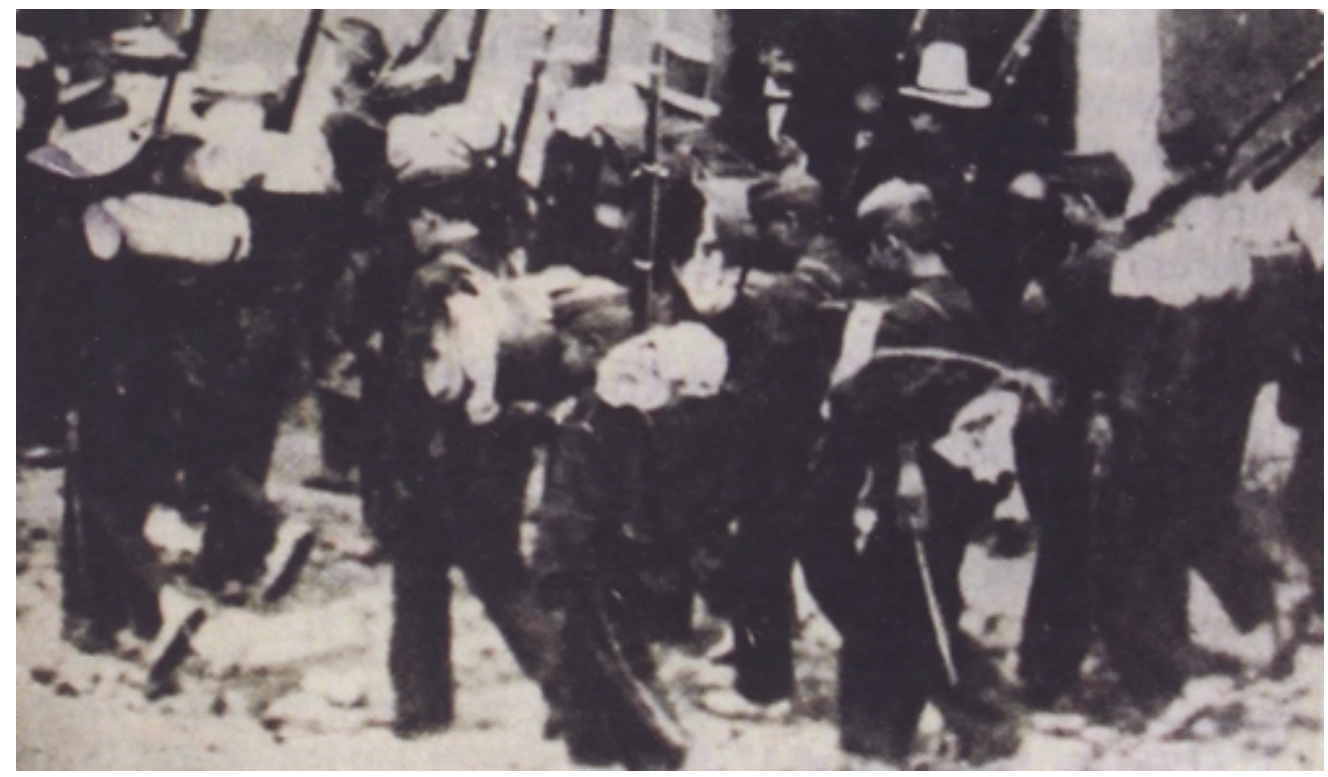

Nota: Tomada de Londoño Vega et al. (2012). Los niños que fuimos: huellas de la infancia en Colombia. Bogotá: Banco de la República.

Fueron los libros de un grupo de periodistas, funcionarios de ONG defensoras de los derechos de los niños, y los trabajos exhaustivos de investigadores sociales independientes (González Uribe, 2002; Human Rights Watch, 2003; Pachón, 2009; Lozano, 2014; Unicef-Gómez Jiménez, 2015), sobre todo, publicados durante la primera década de este siglo, los que demostraron la inhumanidad de lo que estaban haciendo los ejércitos ilegales y obligaron a "visibilizar" el horror y la injusticia que se estaba cometiendo contra los niños en las zonas donde el conflicto armado se vivía de forma encarnizada. 
Imagen 10. El conflicto armado en las regiones

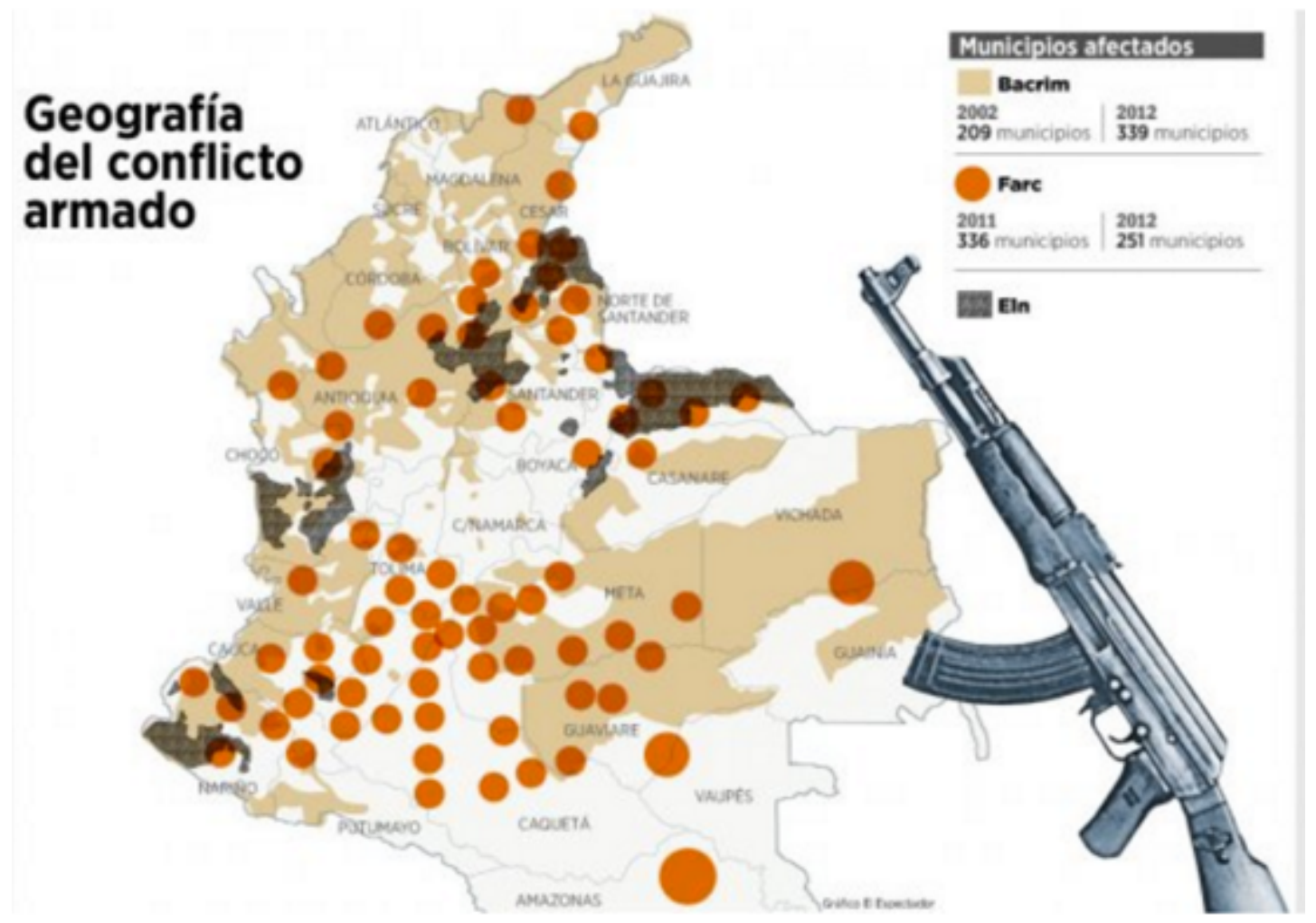

Nota: Tomada de VV. AA. (2013), Geografía del conflicto armado. Bogotá: Corporación Nuevo Arco Iris.

Esencialmente las historias, contadas en primera persona, por los propios niños ${ }^{68}$ y jóvenes que estaban en ese momento en condición de desmovilizados (o "desvinculados" del conflicto armado, como los llamó el Estado) fueron las que hicieron sentir en carne viva un drama de dimensiones imprecisas que había pasado oculto. Entonces se empezó a conocer la verdad.

...Tenía que matar a una señora... yo lloraba y le decía al comandante: 'No, mi comando, yo no hago eso, yo no voy a matar a nadie'. Él me respondió: 'Si no la mata, tiene que morirse usted'.... Y, pues lo hice. Fui y la maté... No sé si la señora era sapa o qué, pero me dio mucha tristeza; uno sin estar acostumbrada a eso. Pero la maté y después ya no me daba miedo nada. Eso es como una costumbre, es como el vicio al cigarrillo, que uno no lo deja. Y así

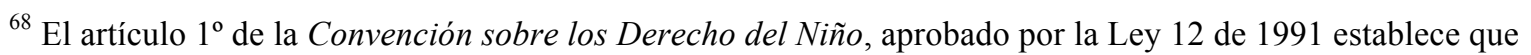
"se entiende por niño todo ser humano menor de 18 años". (Citado por Gómez, 2015, p. 9).
} 
me envicie a quitarle la vida a la gente... Después me mandaron a matar a unos niños y a unos señores. Me volví malísima, porque a uno allá le toca matar a la gente y le toca quitarle los dedos, despresarlos, descuartizarlos. El paramilitar es tenaz. Y me tocaba capar hombres. Uno les pone una bolsa plástica en la cara para que no miren lo que uno les esta haciendo, para que sientan simplemente el dolor; luego los capa, los raja, y les pega un tiro cuando se están muriendo de dolor... (González Uribe, 2000, p. 97).

Esta historia contada por una joven de 15 años, que estuvo con los paramilitares durante dos años, revelaba con toda crudeza lo que habían tenido que soportar los niños para sobrevivir a su paso por los ejércitos ilegales. ¿Cómo se había llegado a esta demencia? ¿Quiénes eran los responsables de tamaño crimen? ¿Quién le enseñó a la niña a matar con tanta sevicia? ¿Quién era la persona a la que asesinó? ¿Qué hizo el Estado -que estaba sobrepasado por las secuelas del conflicto armado- para prevenir o intervenir y proteger a los niños y jóvenes que estaban cometiendo estas atrocidades?

En 2005 -escasamente hace 10 años- se empezaron a conocer los datos -aproximados- de la tragedia del reclutamiento ilícito de los niños y jóvenes ${ }^{69}$. Según el Instituto Colombiano de Bienestar Familiar (entidad a cargo de los niños desvinculados de la guerra) 6 mil habían sido reclutados por las Farc, el Eln y los paramilitares de las AUC. Las ONG Human Rights Watch y Save the Children contradecían esa cifra. La primera hablaba de 11 mil niños reclutados; la segunda de 14.500. En 2010 un estudio contratado por la Fiscalía General de la Nación reveló que los niños de la guerra eran probablemente 18 mil (GMH, 2014, p. 84). Según informaba el Icbf, desvinculados del conflicto en 2006 (por deserción, capturas del Ejército o por desmovilización), en diversos programas estatales de protección, apenas habían 2.800 niños (Pachón, 2009, p. 15).

En el centro del origen de la entrada de los niños y jóvenes a los grupos armados está la pobreza y hallarse en zonas donde el conflicto armado era muy fuerte (GMH, 2013, p. 86; Pachón, 2009, p. 8; Pizarro, 2015, p. 81). En sus relatos los niños lo explican (quien narra es una niña del bajo Putumayo) que fue forzada a ingresar al Eln a los 12 años:

\footnotetext{
${ }^{69}$ Un documento elaborado por la Procuraduría General de la Nación en 2002 señalaba que la edad de ingreso de los niños a los grupos ilegales oscilaba entre los 7 y los 17 años. (Álvarez Correa et al., 2002, p. 32).
} 
Cuando vivía de nuevo con mi mamá, un día se fue a trabajar y quedé con mis cuñadas y mis hermanas, pero ellas salieron a jugar al parque y me quedé sola, cuidando la casa. Al rato timbraron, abrí la puerta y un señor jovencito me preguntó: «¿Usted es de la familia Rodríguez?». Respondí: «Sí, señor», y me dijo: «Alístese que nos vamos». Y yo: « ¿Para dónde?». Respondió: «Soy miliciano y me la voy a llevar para la guerrilla». Le digo: «Pero mi familia no está aquí, ellos no se van a dar cuenta, ¿cómo hago?», y me respondió: «Pues es mejor que no se den cuenta. Vámonos». Le pregunté: «Pero ¿llevo ropa?», y me dijo: «No, allá le dan lo que usted necesite». Yo le iba a dejar una nota a mi mamá y me reprendió: «No haga eso que ella no se tiene que dar cuenta de nada, ni de dónde está». Me hizo subir a una moto, nos fuimos y me advirtió: «Si el comandante le llega a preguntar si es ingresada voluntariamente, le responde que sí; donde le diga que yo la traje obligada, la mato». (González Uribe, 2002, p. 37).

Giraldo (2015) ha resaltado que la acción de los grupos ilegales (guerrilleros y paramilitares) cerró "las posibilidades del desarrollo y la democracia en los escenarios locales" por lo que "la única oportunidad de supervivencia y reconocimiento para los sectores jóvenes de la población era la vinculación a los ejércitos privados” (p. 495). Sin embargo, estas razones no explican todo y es necesario ir más allá. Muchos de estos niños sufrieron violencia intrafamiliar, abandono, orfandad, malos tratos, imposibilidad de asistir a la escuela pública, trabajos forzados en el campo, acoso y abuso sexual, hambre.

Entre mi abuela y mi tía me recibieron el día que nací. Fue en la casa de mis abuelos, una casa de madera, teja de cinc, piso de tierra y fogón de leña, acurrucada en medio de un montón de montañas. (...). Estuve con mi papá, o mejor, él estuvo con nosotros, hasta que cumplí tres años. Es que mis papás vivían enredados en peleas de palabras. Mi papá consiguió una mujer y se fue. Quedó mi mamá. Como al mes, ella también cogió camino. Estaba en embarazo. Pero consiguió un señor y él la recibió así. Mi hermano y yo sentimos ese vacío... (Lozano, 2014, p. 21-22). 
La carencia de oportunidades, la exclusión, están en las raíces del problema. Pero también la cercanía a los grupos guerrilleros y de autodefensas propició cierto culto por la armas y el dinero fácil. Pilar Lozano (2014) sirve de intermediaria para escuchar el relato de una joven guerrillera de las Farc que recuerda sus primeros pasos antes de ingresar:

Lo hizo por curiosidad, por aburrida, no aguantaba más las golpizas del papá. Además, confiesa sin remilgos, quería probar si era bonito. "Me gustaba el uniforme, las armas. Creía que si tenía un arma tendría poder, me sentiría grande, capaz de hacer muchas cosas" (p. 156).

\section{Imagen 11. Niñas reclutadas por las Farc}

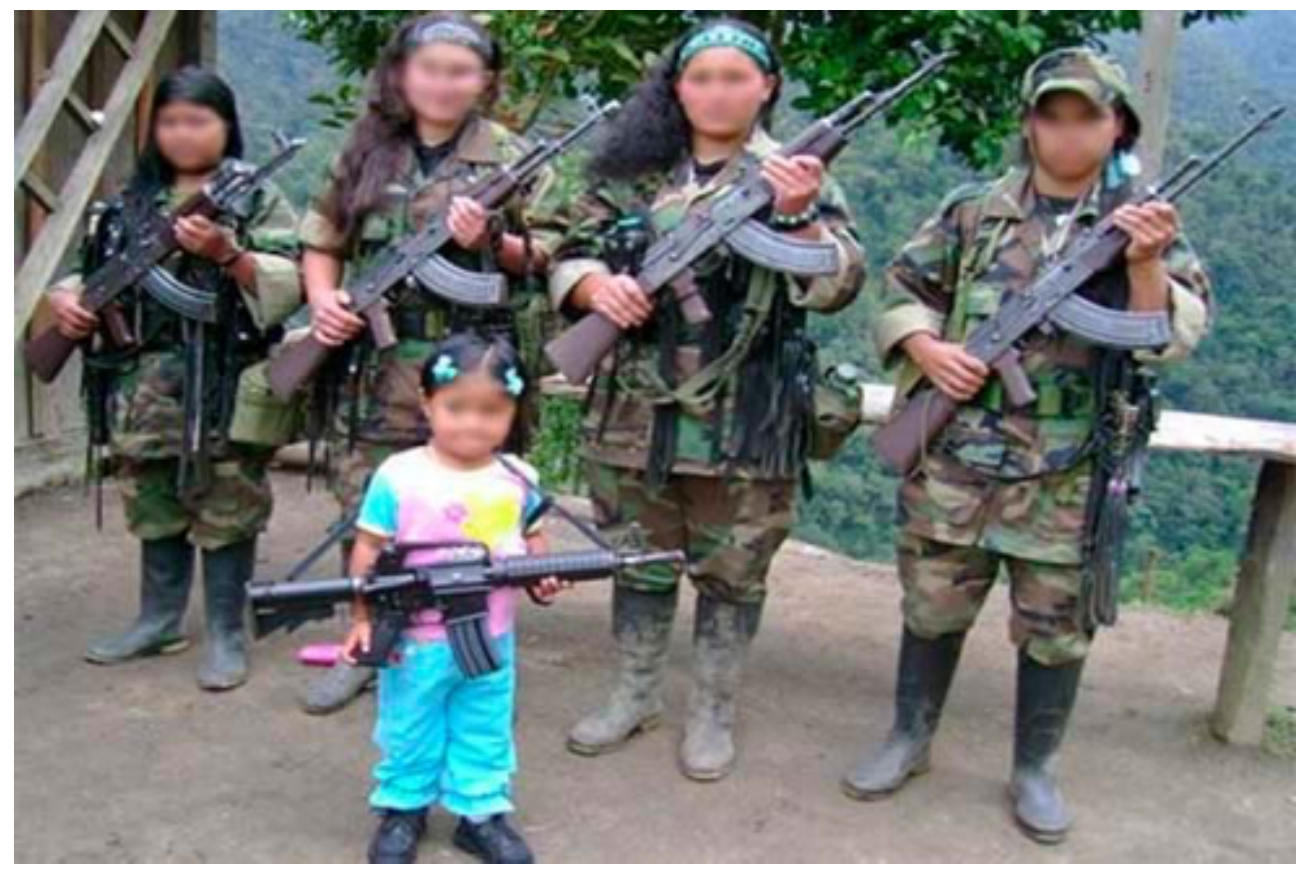

Nota: Tomada de El Espectador. Recuperado de: http://bit.ly/1Shk1PI

Los niños en los grupos armados viven un ciclo complejo, que termina siendo desgarrador. Los reclutadores (tanto de la guerrilla como de los paramilitares) tienen formación para planear el ingreso de los niños y jóvenes ${ }^{70}$. Los niños primero comienzan como recaderos, luego transportan armas, dinero o drogas en sus cuerpos (bajo el criterio de que la policía o el ejército no los revisará). En ocasiones les dan dinero para que ayuden a sus familias y

\footnotetext{
70 "No es fácil entender cual es la lógica existente detrás del reclutamiento de los menores por parte de estos grupos armados. Tal vez la principal razón es la necesidad creciente de engrosar su fuerza de combate y la imposibilidad en muchas zonas del país de asegurarla con hombres o mujeres de mayor edad y más capacitados para la guerra". (Pachón, 2009, p. 9).
} 
luego sí pasan al proceso de ingreso formal. En la guerrilla deben llenar un registro (con su nombre, dirección, nombres de familiares) para prevenir la deserción y en caso extremo buscarlos y ordenarlos matar; en los paramilitares hay un contrato (verbal) con promesa de salario. Juntos tipos de reclutadores les entregan uniforme y comienzan la fase de preparación para los combates. Esto es atroz para niños que apenas con 12-13 años ya deben soportar rutinas de entrenamiento militar para adultos. El rito clímax para ser aceptado en la guerrilla es participar en un combate y con los paramilitares es matar a alguien en estado de indefensión, generalmente en una masacre programada o presenciar los hechos como lección de guerra:

A un compañero sapo le pegaron una matada que nunca le habían hecho a alguien. Lo cogieron, lo amarraron, lo torturaron, le sacaron los dientes con un alicate, hasta que no quedó ni uno; dentro de las uñas le metieron alfileres y a lo último le arrancaron las uñas y empezaron a quitarle partecita por partecita. Ya cuando empezó a agonizar, a lo último, lo metieron dentro de una caneca y le echaron llantas y gasolina, lo taparon y listo, se quemó. Cuando fuimos a mirar no quedaba nada, solo cenizas. Eso lo hicieron enfrente de todos. (González Uribe, 2000, p. 107).

En los grupos ilegales los niños entran en una fase de adultez forzada. Deben convivir en condiciones climáticas adversas, con riesgo de sufrir enfermedades como malaria o paludismo, hacer largas guardias nocturnas y caminatas de 15 a 18 horas. El peso del armamento (fusil, balas, granadas, cuchillo, machete) y de los pertrechos (olla, cobija, alimentos) los sobrepasa por lo que sufren enfermedades en los riñones o en la columna vertebral. Son forzados tempranamente a llevar vida sexual por la presión de grupo. Sobre todo en la guerrilla, las jóvenes que no siguen métodos anticonceptivos, quedan embarazadas y son obligadas a abortar sin la ayuda de ningún procedimiento médico, poniendo sus vidas en riesgo (Pachón 2009, p. 14).

La humillación es permanente, los castigos. La acusación de ser "niño" sirve de pretexto a los comandantes o a los más soldados más adultos para poner a los menores a hacer tareas degradantes. El autoritarismo, el machismo más ramplón salen a flote: "hay que ser un berraco", "hacerle a todo". Los reclutadores de las autodefensas (generalmente militares 
retirados o mercenarios) someten a los niños a pruebas de comando o de marine. Entre tanto, en los grupos guerrilleros hay manipulación con los ascensos y la posibilidad de manejar dinero, producto de secuestros o del cobro del "impuesto" al cultivo de hoja de coca. En los casos extremos, se les somete a pruebas militares más peligrosas, como lo confiesa una joven guerrillera que estuvo en el Eln:

Después de eso me tocó pasar a un entrenamiento nuevo, de explosivos, para tropas especiales. A mí no me gustaba el explosivo, pero me tocaba hacer el curso porque era una orden, y el que tiene responsabilidad tiene que ver todo eso; y cuando uno pasa el entrenamiento, tiene que ir a dictarles entrenamiento a los que son combatientes. Estuvimos seis meses haciendo ese curso. (González Uribe, 2000, p. 147)

Sin embargo, los niños guerrilleros o paramilitares, incluso viviendo todo este proceso brutal de adaptación a la guerra, siguen siendo niños en muchos de sus actos cotidianos:

Eran pocos los momentos en que podíamos estar cerca, como en grupo, como descansando: cuando nos mandaban a lavar, a baño, o a la hora del almuerzo. Ratos muy cortos para hablar, para contarnos secretos, dolores. Lo primordial era la falta de la mamá. Ese es el vacío más grande. Todos la extrañábamos. (Lozano, 2014, p. 39).

Los niños no pierden fácilmente la humanidad como los adultos que llevan años en la guerra y para quienes un crimen más o uno menos, no quita. Los niños mantienen su amor por la familia, así allí hubieran sufrido toda clase de pobrezas o castigos. Piensan en seguir estudiando y ser arquitectos o enfermeras (HRW, 2003, p. 167; González Uribe, 2002, p. 42), en enviar dinero a sus casas para ayudar a sus hermanos desamparados (Lozano, 2014, p. 181).

Pese a todo el horror vivido, tienen esperanza. Los niños desvinculados del conflicto -lo confiesan reiteradas veces- quieren tener futuro. Lo ven difícil, riesgoso (algunos siguen amenazados de muerte por sus antiguos reclutadores). Tratan de vencer los "cantos de sirena" de los grupos armados que los invitan por un millón de pesos a irse a la guerra de nuevo. No todos lo logran. Los daños psíquicos que han sufrido son demoledores. Las pesadillas, el insomnio, la culpa, el miedo permanente no son fáciles de llevar: 
Los jóvenes describen escenas dantescas - el suplicio de los cuerpos, el olor de la sangre - que han quedado inscritas en su memoria, atormentándolos en los sueños y alterando su capacidad de atención, concentración, memoria y aprendizaje. Estas experiencias lesionaron las bases de confianza y de protección que requerían para su desarrollo personal GMH, 2013, p. 315).

El Estado, el Icbf, en alianza con varias ONG -defensoras de los derechos de los niños y jóvenes- ha implementado varios programas con los niños que estuvieron en grupos armados. Una especialista señala que los alcances de reinserción han sido limitados:

Se menciona el bajo cubrimiento y las irregularidades en el proceso, además de la falta de claridad que tienen los jóvenes en relación a su situación presente y sobre lo que les depara el futuro. El inquietante porcentaje de jóvenes que desertan de los programas y no completan el ciclo establecido, 25 por ciento aproximadamente, además de la existencia de un número muy grande de procesos en contra de estos ante los Juzgados de Menores, son también aspectos preocupantes (Pachón, 2009, p.15).

Hay expectativa de que las Farc, como gesto humanitario, liberen a los niños guerrilleros antes del Acuerdo de Paz que deberán firmar con el gobierno colombiano en marzo de 2016. Hasta ahora las actitudes han sido distintas ${ }^{71}$. Uno de los comandantes, en una entrevista al diario español El País, justificó cínicamente el reclutamiento de menores:

P. ¿Van a dejar de reclutar menores de edad?

R. Estamos considerando la posibilidad de frenar el reclutamiento. Si vamos para la paz, no tiene sentido ingresar muchachos.

P. ¿Piensan permitir que dejen la guerrilla?

R. Por ahora no. Eso significaría quedarnos sin fuerza.

P. ¿De qué porcentaje se trataría?

\footnotetext{
${ }^{71}$ Una noticia del 10 de febrero de 2016 informa al respecto: "Este martes, las Farc anunciaron el fin de la incorporación de menores a sus filas guerrilleras. "Hoy comunicamos al país nuestra decisión de poner fin a la incorporación de menores de 18 años a las Farc', dijo la negociadora Victoria Andino, al leer un comunicado". "¿Qué significa el nuevo anuncio de las FARC acerca del reclutamiento de menores?". Semana. Recuperado de: http://bit.ly/20pjKJV.
} 
R. No lo tengo en la cabeza. Pero sí puedo decir que la guerrilla mayoritariamente está integrada por gente joven. En el campo nos dicen: 'Pasaron los muchachos', somos gente joven, yo me siento joven aunque tenga mis años. (Lafuente, 2015 , p. 17) ${ }^{72}$.

Se debe recordar que el reclutamiento de niños y jóvenes por parte de los grupos armados ilegales es delito de lesa humanidad, esto es, no tiene amnistía, ni es protegido por ningún acuerdo de justicia transicional.

Los comandantes de las guerrillas y los paramilitares han justificado la inclusión de niños en sus ejércitos diciendo que estos ingresaron por su propia voluntad ${ }^{73}$. La Corte Constitucional, en un fallo de 2008, contradice este argumento y ha señalado:

... que existe certeza jurídica sobre el carácter forzado y criminal del reclutamiento de menores de edad en todos los casos, independientemente de su apariencia de voluntariedad. Este carácter voluntario del reclutamiento es simplemente aparente, ya que está motivado por razones de manipulación perversa y engañosa mediante las que los actores armados se aprovechan de la situación de vulnerabilidad, pobreza, desprotección, abandono, debilidad psicológica y falta de acceso a servicios de salud, educación y recreación de los menores. (GMH, 2013, p. 86).

El único reclutador de menores para la guerra que lo ha reconocido pagará únicamente 8 años de $_{\text {cárcel }}{ }^{74}$. Fue penalizado en 2011 bajo la Ley de Justicia y Paz. Con ello se envía una señal grave: el reclutamiento ilícito de menores es un problema de segundo perfil para la justicia y los victimarios ganarán y no dirán nada, ni aceptarán ninguna responsabilidad. Ello se comprueba de modo evidente, pues en la agenda de las asociaciones de víctimas que se

\footnotetext{
${ }^{72}$ Recuperado de: http://bit.ly/11AAZuz.

${ }^{73}$ La investigadora Ximena Pachón - citando un Informe de la Defensoría del Pueblo de 2005- señala que "que el $90 \%$ de los niños que estaban en la guerrilla, manifestaron haber entrado por voluntad propia. De ellos, al $33 \%$ los atrajo las armas y los uniformes, a otro $33 \%$ fueron las condiciones de pobreza las que los llevaron a tomar esta decisión, al $16 \%$ porque crecieron conviviendo con ella, y el $8 \%$ se vinculó por enamoramiento, decepción amorosa o sentimiento de venganza porque sus familias y bienes habían sido destruidos 18 y el entrar a una de estas organizaciones era el único medio que consideraban les permitiría algún día vengarse". (Pachón, 2009, p. 6).

${ }^{74}$ Es el comandante paramilitar Fredy Rendón Herrera, alias “El Alemán”, quien aceptó haber reclutado 399 menores. Recuperado de: http://bit.ly/1orXqU9.
} 
negocia en este momento en La Habana entre el gobierno colombiano y las Farc, no fue un tema de discusión relevante. En un comentario en la revista digital La Silla Vacía ${ }^{75}$ he escrito:

Me sorprende que ninguna de las asociaciones de víctimas mencione a los niños y niñas, jóvenes reclutados por los grupos armados, que también tienen la condición de víctimas $^{76}$. Centradas aquellas en su particularidad, olvidan que los niños no se representan por sí mismos, sino por la mediación de los adultos. Dependen de ellos para reclamar sus derechos y su condición de ciudadanos (el art. 44 de la Constitución Nacional establece que "Los derechos de los niños prevalecen sobre los derechos de los demás"). En medio del conjunto de discursos que reclaman verdad, justicia y reparación, no se nos debería pasar por el alto que lo sufrido por los niños y las niñas como víctimas del conflicto armado "no tiene nombre" (parafraseando el título de la novela de Piedad Bonett) y que es de mínimo respeto -y dentro del espíritu de "ética compasiva" reclamado por Reyes Mate como base de un acuerdo de reconciliación- tenerlos en el centro de cualquier discusión sobre un posible acuerdo de reparación a las víctimas.

\footnotetext{
${ }_{76}^{75}$ Recuperado de: http://bit.ly/1QVDhyX.

${ }^{76}$ Según la Ley de víctimas (Ley 1448 de 2011), "los miembros de los grupos armados organizados al margen de la ley no serán considerados víctimas, salvo en los casos en los que los niños, niñas o adolescentes hubieren sido desvinculados del grupo armado organizado al margen de la ley siendo menores de edad". (Citado por Gómez, 2015, p. 9).
} 


\section{Imágenes 12 y 13. Los niños sufriendo el desplazamiento forzado}

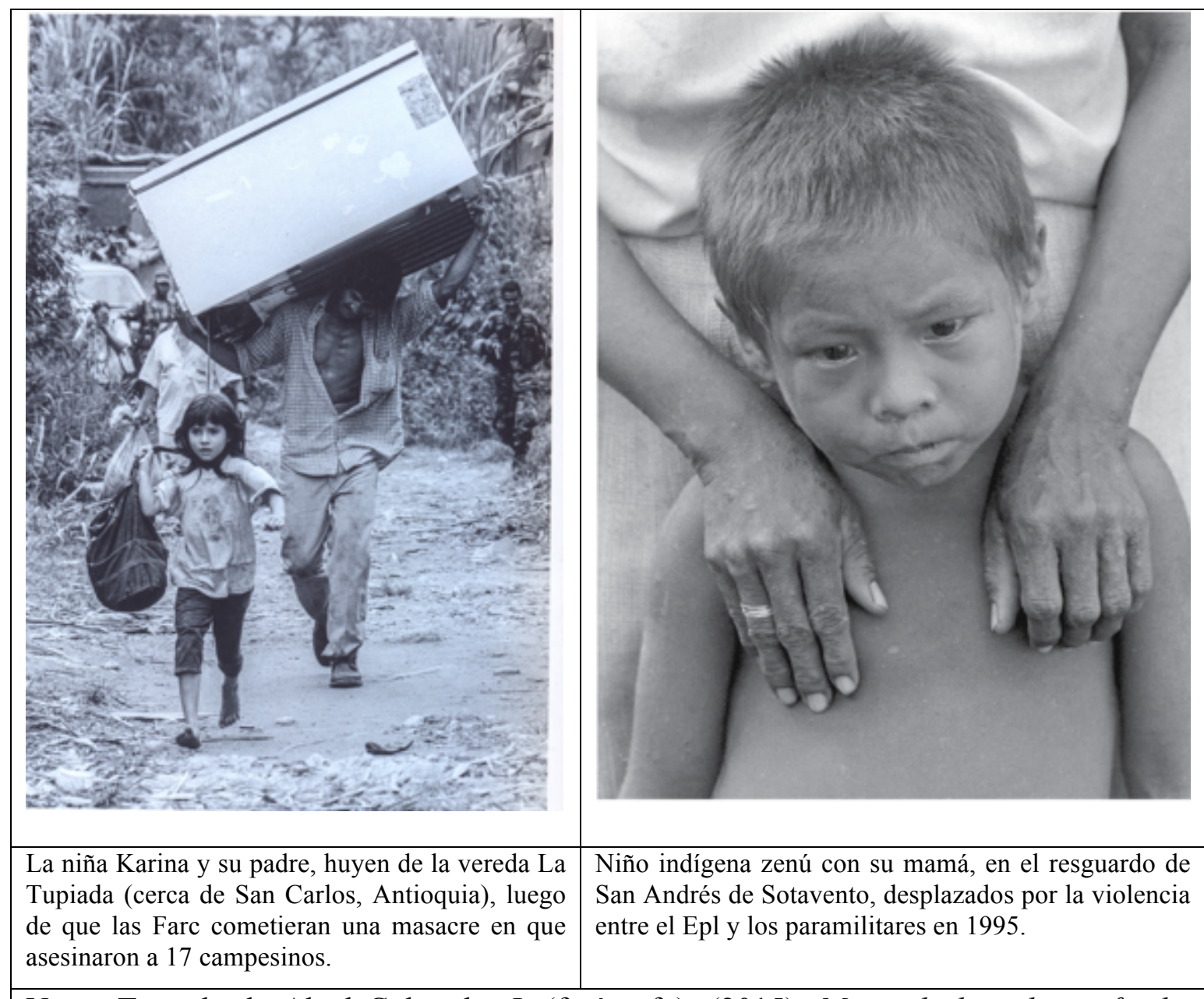

Nota: Tomada de Abad Colorado, J. (fotógrafo). (2015). Mirar de la vida profunda. Bogotá: Planeta.

La presencia de los niños en los grupos armados ilegales es parte del drama humanitario que han tenido que sufrir a causa del conflicto armado. Pero también han sufrido los efectos arrasadores de la guerra en sus vidas cotidianas. Según información del Registro Único de Víctimas (RUV), en un balance elaborado en 2013 (citado por el GMH, 2013, p. 314), entre 1985 y 2012, 2 millones y medio de menores de edad han sido desplazados, 70 han sido víctimas de violencia sexual, 154 de desaparición. El Grupo de Memoria Histórica, en ;Basta $y a !$, concluye de forma demoledora:

Los niños y las niñas han experimentado la violencia de manera dramática y cruda. Han observado hechos atroces, como el asesinato y la tortura de sus 
padres, madres, familiares y vecinos, o la quema y destrucción de sus hogares, enseres, animales queridos y objetos personales. Muchos de ellos y ellas tienen marcas permanentes en sus cuerpos debido a la amputación de miembros por efecto de las minas antipersonal, o han sufrido abuso sexual, tortura, reclutamiento ilícito, y entrenamiento para la guerra por parte de los grupos armados. (GMH, 2013, p. 314)

Imagen 14. Hijo ante el cadáver de su padre, asesinado por paramilitares.

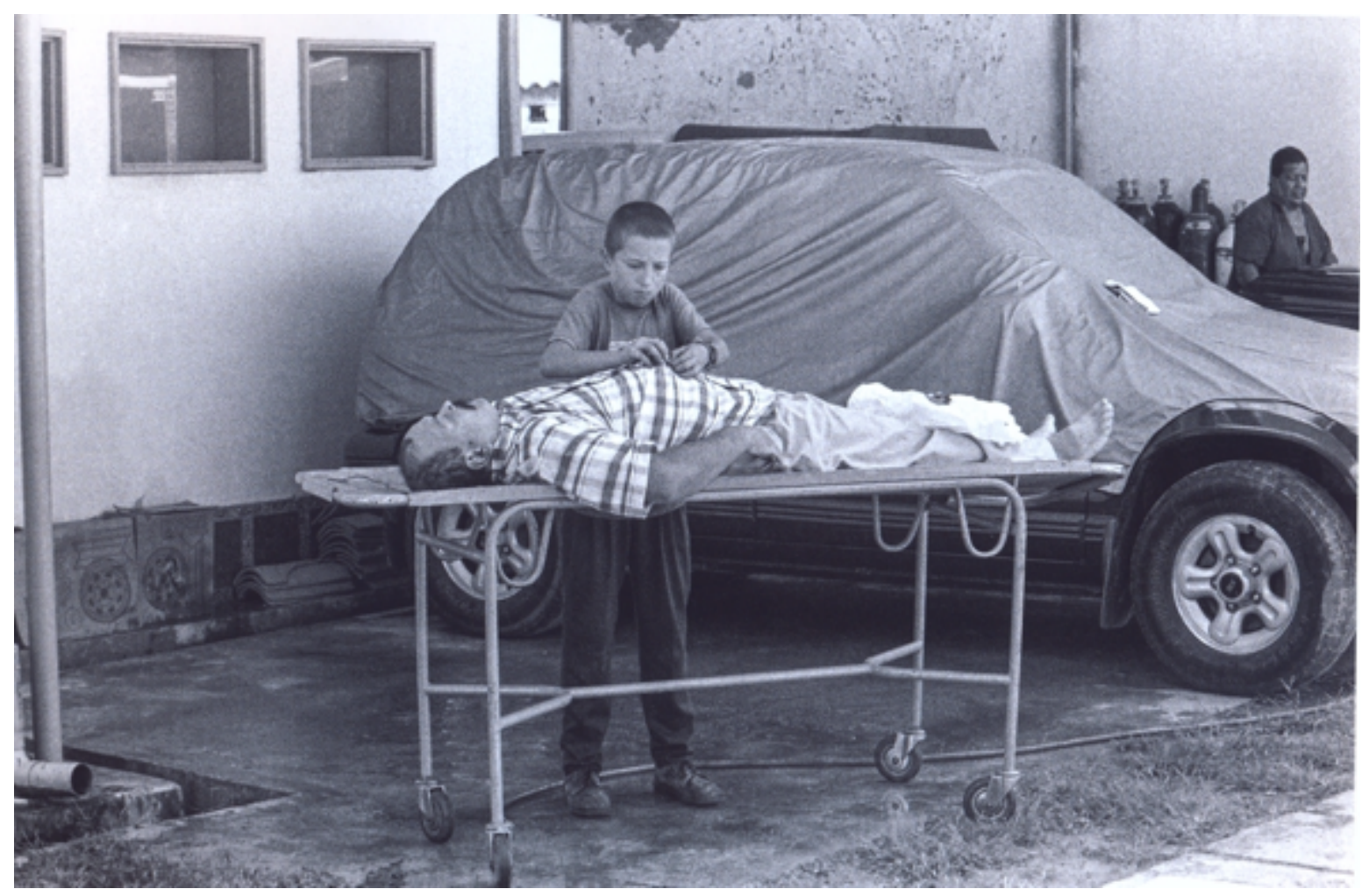

Nota: El hijo de Eduardo Salazar -asesinado por los paramilitares en San Carlos Antioquia en 1998, junto a trece personas más- ajusta la camisa del cadáver de su padre. Tomada de Abad Colorado, J. (fotógrafo). (2015). Mirar de la vida profunda. Bogotá: Planeta.

¿Cómo es que un país - una sociedad en su conjunto que se supone cohesionada alrededor de un conjunto de leyes provenientes del derecho positivo y de valores que incluyen el respeto a los derechos humanos- acepta esto, o al menos sabiéndolo, voltea la mirada para otro lado? ¿Cómo es que no presionó al Estado o actuó de forma explícita para frenar el horror que han vivido millones de niños de nuestro país? ¿A causa de qué debían soportar este martirio? ¿Acaso no son colombianos? Muchos de los niños que han vivido la guerra provienen del 
campo y de las zonas más empobrecidas del país, son campesinos, indígenas, afrodescendientes. ¿Son ciudadanos de tercera clase? ¿Para ellos no rige la Constitución Nacional ni las leyes internacionales o nacionales que los protegen? El abogado Mario Gómez (2015) tiene razón al afirmar: "es posible afirmar que en variados casos, ni en forma cuantitativa ni cualitativa se visibilizan los derechos vulnerados a niños y niñas con el esmero y la amplitud que la mencionada prevalencia de tales preceptos podría exigir” (p. 11).

A los niños que fueron reclutados por las guerrillas y por los paramilitares les robaron su niñez. La niñez, en marco amplio del desarrollo humano según los constructivistas (Vygotski, 2000; Piaget, 1993; Ferreiro, 2013), es la fase de la vida para la imaginación, el juego, el descubrimiento, la creatividad, la entrada en la cultura escrita y el desarrollo de todas sus potencialidades.

Imagen 15. Niño guerrillero del EIn. Serranía de San Lucas, sur de Bolívar, en 2000.

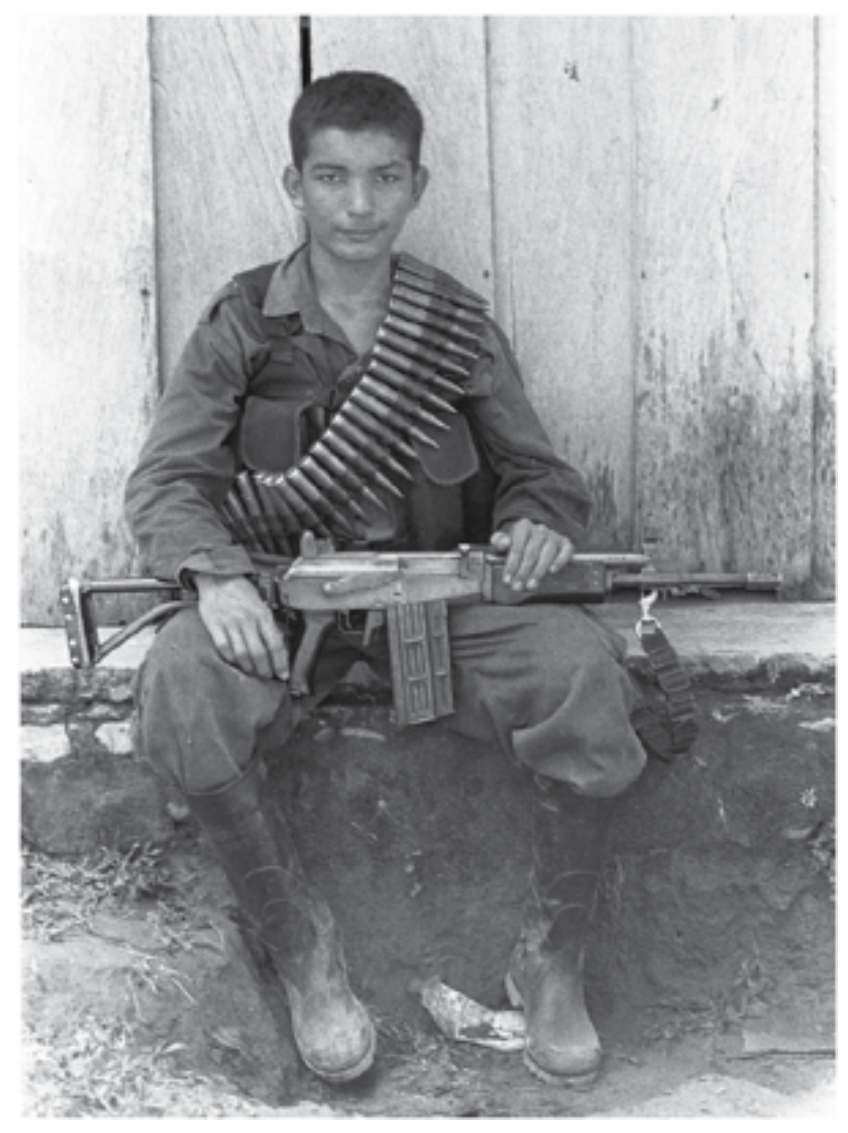

Nota: Tomada de Abad Colorado, J. (fotógrafo). (2015). Mirar de la vida profunda. Bogotá: Planeta. 
Mientras en las grandes ciudades los niños y adolescentes -incluso los de origen social más humilde- iban en las mañanas a las escuelas y colegios, participaban en clase, salían a conversar o jugar al descanso, atendían los videojuegos en sus celulares, u oían leer un cuento a una bibliotecaria escolar, este joven de 13 años, reclutado por la guerrilla, hacía una cosa totalmente diferente en algún lugar de la geografía nacional donde se desarrollaba el conflicto armado:

El primer combate en que estuve fue cinco meses después de ingresar a las Farc. Mataron a muchos guerrilleros, yo estaba paniqueado. Lloré durante el ataque. Había helicópteros encima de nosotros. Yo me escondí en una zanja. Disparé un par de veces sin quererlo. Hubo luego otro ataque a un puesto de Policía al que me tocó ir en primera fila disparando. Yo tenía mucho miedo. Matamos a los catorce policías, siete durante el combate y los otros siete se rindieron y fueron ejecutados. Yo lo vi todo. (HRW, 2003, p. 121).

Como lo señaló Guillermo González Uribe en la Introducción a su desgarrador libro Los niños de la guerra (2002):

Al ver estos niños y escuchar sus historias uno se reafirma en la necesidad de hacer reformas de fondo en el país (...). Que mientras haya situaciones de miseria y pobreza extrema, que mientras sigan siendo maltratados en sus núcleos familiares y no tengan posibilidades de estudio y desarrollo, los niños seguirán formando parte de la guerra. (p. 22).

\section{ARguMento de ERA COMO MI SOMBRA}

\section{Capítulo 1}

Dos niños campesinos (el narrador y su amigo Julián) están ayudando a arriar un ganado y jugando. Súbitamente contemplan como un sicario le disparan a un hombre (luego sabremos que es guerrillero y que estaba haciendo una guardia) y lo mata de tres tiros. El niño narrador piensa que a él también le van a disparar, pero el matón se va. Los dos niños quedan temblando y luego salen a correr hacia sus casas en un caserío rural. El narrador siente que hay un augurio nefasto cada vez que se le aparece la "pata" del arcoíris (en el cielo se ve en la mitad el sol, rodeado por los colores). Este será un leitmotiv a lo largo de la novela como anuncio (agüero) de que vendrán malos momentos para el narrador. 


\section{Capítulo 2}

Dice el niño narrador: "Julián y yo nacimos en el mismo pueblo, un pueblo de montaña, de una sola calle larga. Lo que se levanta en esa calle parece seguro. Lo demás cuelga a lado y lado, como agarrado de la nada. La cantina, los billares, la tienda de Pedro, la escuela y la iglesia -a la que de cuando en cuando iba un cura- son lo único importante. Realmente no es más que un caserío". Se resalta la pobreza extrema de las familias de juntos. El narrador va a la escuela; Julián no, pues sostiene a una abuela enferma y a una "hermana tullida". Trabajan en el matadero haciendo pequeñas cosas y luego se van a jugar "piquis". El narrador tiene a su tío Pedro, quien junto a su abuela, son quienes lo cuidan. Ocasionalmente los tres -el tío Pedro, su sobrino y Julián- salen a buscar trabajo como recolectores de café en un lugar distante. Se describe a Julián como un niño retraído, sumamente callado. El narrador justifica esta actitud diciendo que desde pequeño la mamá lo golpeaba brutalmente.

\section{Capítulo 3}

En este capítulo se retrata al tío Pedro. El narrador siente, literalmente, admiración y respeto por él, pues remplaza a la figura paterna que lo ha abandonado. La mamá tampoco está, pues se ha ido a trabajar a otro pueblo como cocinera. El narrador tiene un hermano mayor, que es descrito como un niño hosco y con el que siente poca empatía. Al tío Pedro le gusta escuchar en la noche un programa de tango que el niño narrador también oye con pasión. Es un campesino humilde que trabaja como peón en fincas donde le ofrecen trabajo. Pero tiene un secreto: es miliciano de la guerrilla ("informante" en palabras de los "paramilitares"). Su función es repartir volantes y periódicos de uno de los grupos guerrilleros. Le enseña a su sobrino y a Julián a cazar animales con una escopeta. En este capítulo se aclara que Martínez (capítulo 1) era guerrillero y quien lo mató fue probablemente un hombre de otro grupo guerrillero, o quizás algún paramilitar. El niño narrador cuenta que es la primera vez que presencia una toma guerrillera. La balacera es espantosa y todos se tiran al piso. Reina la calma por unos días, pero el pueblo cambia de autoridad cada nada: vuelve la policía o el ejército o los "paras". El niño narrador siente gran nostalgia y miedo cuando su tío se va en tareas de educación política. Y así se pasan los 9, 10, 11 años del protagonista y su amigo Julián. Cuando hablan de lo que serán en futuro sueñan en ser "maquinistas": manejar la 
retroexcavadora que ayuda a remover los derrumbes. Por eso los campesinos quieren a estas personas.

\section{Capítulo 4}

Un día el niño contempla de nuevo en el cielo la pata del arcoíris, lo que para él es señal de "mal agüero". En efecto por esos días un grupo armado llega al pueblo. Hacen bajar de una “chiva" a los campesinos para requisarlos y el tío Pedro se enfurece gritándoles: "No jodan a la población civil". Hay un careo con los armados. El niño presiente que esto es grave y llama a la mamá. Ella le ruega a los hombres armados que no le hagan nada a su hermano. Sin compasión, estos disparan sobre el tío Pedro que cae el piso, mortalmente herido. Antes de poder hacer nada y llevarlo a un centro médico, fallece. El niño narrador queda con el corazón roto. Recuerda la calidad de ser humano que era su tío (en Navidad le daba a él y a Julián regalos sencillos en medio de la gran pobreza en que vivían). Esta es una de las causas por las cuales el niño desea irse a la guerrilla: quiere vengar a su tío.

\section{Capítulo 5}

Con gran tristeza el niño finaliza su grado $5^{\circ}$ en la humilde escuela del pueblo. El dolor y la pena que siente por su tío no pasan. Siente ganas de beber alcohol. Esa Navidad no hay regalos. La abuela por ayudar a su nieto le permite tomar unos huevos del gallinero y venderlos. El niño, junto a Julián, usan el dinero para comprar Bom Bom Bum. Les regalan los dulces a algunas niñas del pueblo de las que están enamorados. Cuando se acaban los huevos de regalo de la abuela, entonces los roban en fincas cercanas. Esto le hace recordar al narrador que ese ejercicio de arrastrarse por el piso (“culebrear” le servirá luego “allá”, en la guerrilla, para esconderse y combatir contra el Ejército. El recuerdo del tío vuelve: quería que su sobrino estudiara y que se volviera ingeniero. Pero la escasez de dinero trae el hambre. Un guerrillero reclutador que ha pasado por el pueblo le ha hecho la dicho al niño que ingrese. El niño duda: es un buen estudiante y su tío jamás hubiera estado de acuerdo con que tomara la decisión de irse a la guerra.

\section{Capítulo 6}

El niño ha decidido ingresar a un grupo guerrillero (no se indica cuál). La mamá ni la abuela están de acuerdo. El niño ve que no hay otra opción de futuro en ese pueblo. Se va a la escuela a despedirse de su maestra Elvira quien lo quiere mucho. Los niños compañeros le insisten 
en que desista de la idea de enrolarse. La profesora le dice con culpa: “¿En qué fallé?”. El niño recuerda los esfuerzos heroicos de la profesora Elvira por mantener al grupo unido, muchachos de todos los grados de primaria en un salón pobrísimo. Ella, quien también es humilde y vive a dos horas, pone de su salario para comprar un mapa. En un gesto de bondad inmenso hace un computador en cartón para enseñarles a los niños cómo se manejaría cuando tengan uno de verdad ("Ustedes no se pueden quedar atrás"). Este saber le servirá al niño luego, pues manejará el computador del comandante del frente guerrillero, donde aquel incluye la información secreta: secuestros, dinero, integrantes de cuadrillas. La profesora Elvira, además, debe soportar la desconfianza del comandante de un batallón del Ejército que la hace llamar a interrogatorios acusándola de colaboradora de la guerrillera. La maestra Elvira es ingeniosa y hace un croquis con los lugares donde la guerrilla ha puesto minas quiebrapatas, para que sus alumnos nos las pisen. Luego ya en la guerrilla el niño recordará con mucho cariño a esta profesora por evitar que sus alumnos ingresaran a los grupos armados.

\section{Capítulo 7}

El niño ha partido para la guerra. Lleva solo una oración religiosa y una foto de su mamá. Tiene 13 años cuando ingresa al grupo guerrillero. Allí los primeros meses son de gran esfuerzo: es recadero, cocinero, estafeta. Luego asciende a guarda y debe avisar cuando el Ejército se acerque. La primera tarea de guerra es ir a quemar papelería para las votaciones. Cuando comete un error debe cargar leña varios días. La única recompensa es que cuando va al pueblo la gente lo admira. El joven guerrillero siente que el uniforme y las armas le dan poder. Tiene un rapto de vanidad.

\section{Capítulo 8}

La mayor sorpresa del niño narrador es cuando ve llegar a su amigo Julián a la guerrilla. Para él -que no había podido estudiar- tampoco habían opciones diferentes a las armas. Los primeros días de Julián allí no son fáciles: se duerme haciendo guardia o escuchando las clases de teoría política sobre lo injusta que es la "burguesía colombiana". Tiene, eso sí, un gusto por los animales, que lo diferencia de los otros guerrilleros. Pero además todavía es un niño: le gustan las canicas y las colecciona. Un día un guerrillero jefe se las hace botar todas. Con el niño narrador en alguna ocasión les toca servir de guardaespaldas del comandante de 
frente, pues este ha ido a un pueblo a un lugar de prostitutas. El niño narrador se va dando cuenta de que la injusticia y los desmanes comienzan en "casa”. Le dice a Julián: “¿No es injusto que un niño que debe estar jugando y estudiando termine en la guerrilla o en los paramilitares?".

\section{Capítulo 9}

El niño cuenta la dura disciplina que debe desarrollar para formarse como combatiente. Cuando los niños guerrilleros no hacen lo correcto, los comandantes les quitan el arma, lo que los deja en condición de gran vulnerabilidad. El niño narrador recuerda que uno de los mejores comandantes que tuvo fue El Calvo, porque antes de una toma o un combate organizaba fiesta, con "piquete” incluido, pues creía que si iban a morir, era mejor despedirse de la vida feliz. En cambio otros comandantes no tenía ningún tipo de respeto por los niños guerrilleros y los ponían en el combate con el Ejército casi sin munición al frente como "carne de cañón". El narrador recuerda que por sus habilidades militares llegó a dirigir muy joven una cuadrilla de compañeros. Se narra uno de los combates y cómo en el enfrentamiento mató a un soldado. Pero el momento en que se siente más degradado, y percibe la injusticia de modo real, es cuando por orden de un comandante debe matar a un campesino, acusado de ser "informante” del Ejército. Eso no se lo perdonará a sí mismo jamás: "Cuando nos vio se sentó entre unas matas llenas de flores. Se achicó, suplicaba con sus ojos desorbitados. Movía los labios sin lograr pronunciar nada. Se le murieron primero las palabras”. La última frase del capítulo ya es diciente de sus primeras críticas a la guerrilla: "Desde ese día, órdenes que había cumplido sin remordimientos, ni consideraciones, comenzaron a inquietarme”.

\section{Capítulo 10}

El niño guerrillero mira la foto de su mamá y la recuerda con especial afecto. Hace un perfil de ella. Una mujer humilde, luchadora, "experta en estirar centavos". Lava ropas ajenas, luego consigue una máquina de coser y trabaja todo el día. Por ella es por quien vive. Antes de cada combate la invoca leyendo la oración religiosa que ella le regaló antes de irse a la guerrilla. También el narrador recuerda un encuentro con el hermano mayor con el que ya aparentemente ya se ha reconciliado. Pero volver al pueblo se ha vuelto imposible, pues los "paras" se tomaron y quemaron el lugar. Por otro compañero, el narrador se entera de que su 
abuela ha muerto, lo que lo sume en un profundo dolor. También la mamá de Julián ha fallecido. Se proponen llevarles flores a la tumba apenas puedan.

\section{Capítulo 11}

Este capítulo está dedicado a evocar a Matilde, la niña guerrillera. El narrador recuerda que eran compañeros de escuela y que ella era muy tímida y lloraba por todo. Matilde entra a la guerrilla a los 12 años, aburrida del padre que maltrataba a la mamá. La niña sufre mucho en los combates porque no se acostumbra a ver muertos: se desmaya. Además, apenas si puede cargar el arma y la dotación que le han dado. Dice el narrador: "No sé cómo logró pasar las maniobras más complicadas: traspasar minados, hacer avances sin ser detectada, practicar tácticas de asalto, saltar alambrados, cruzar caños". Julián está enamorado de ella, pero por su timidez nunca logra más que darle la mano para ayudarla. Aquí sabemos que el narrador -que ya es joven- tiene relaciones sexuales con compañeras guerrilleras. El capítulo se cierra contando que Matilde se acercó a los “duros”, a los comandantes, que ya le tenían confianza. Pero la niña muere de manera atroz: cuando está en labores de "inteligencia" en un pueblo es capturada por los "paras". Se deja a la imaginación del lector las torturas que debió haber sufrido.

\section{Capítulo 12}

"Si miro para atrás y hago cuentas, desde el segundo año de estar allá, de cuando en cuando se me atravesaba la idea de volarme", dice el joven guerrillero. Pero desiste de hacerlo de modo inmediato. Baja a un pueblo cuando puede y va a un colegio, donde habla con los profesores y algunos estudiantes. Una de ellas, Mayerly, se enamora de él y quiere seguirlo ingresando a la guerrilla. Él se opone rotundamente. Un día el comandante le comunica que lo trasladarán de frente, lo que lo enfurece, pues no volverá a ver a su novia. En la despedida

ella le entrega un papel: "La guerra no es un juego de niños. ¿Tienes motivos para estar en ella? ¿No has pensado en dejarla?’. La duda empieza a hacer mella en él. Hace un balance de cómo es la guerrilla por dentro y reconoce lo injusto que es dar esa batalla a nombre de ellos. Entonces decide fugarse, desertar. Julián, como siempre su "sombra", se le une. La escena de escape es de gran tensión. Consiguen engañar a un mando medio y la mamá de Mayerly le consigue un carro con chofer para que se fuguen. Unos guerrilleros los siguen en otro carro. El carro donde van el conductor, el narrador y Julián se atasca en la carretera. Son 
alcanzados. Solo el narrador alcanza a escapar. Los fusiles apuntan a la cabeza de Julián, quien es capturado por sus antiguos compañeros.

\section{Capítulo 13}

El joven narrador, ahora de civil, protegido por alguna entidad del Estado a cargo de los niños de la guerra, rememora el pasado inmediato. No le es fácil acostumbrarse a la nueva vida. Extraña a Julián, la época en que viajaron por medio país (llanos y selvas) como guerrilleros. Pero también evoca la dura vida como combatientes: cargar el equipo de 20 kilos, el acoso de los helicópteros y los aviones del Ejército, la sensación de morir de un balazo... El psicólogo de la entidad donde está protegido trata de que hable más, pero le es difícil. Todavía es reciente el dolor de imaginar que Julián fue sentenciado a morir en el consejo de guerra que seguramente le hicieron en la guerrilla. No puede perdonarse eso. Ese día vio en el cielo el viejo augurio: la pata del arcoíris. De pronto, renace la esperanza: quiere terminar sus estudios, devolverse al campo a tener su pedazo de tierra. Ha descubierto su identidad al fin: quiere ser heredero del legado de su tío Pedro, al que tanto amó y que ha sido su referente de vida:

Yo, dueño de un pedazo de tierra en la montaña, bonito, con agua por todo lado, para no andar de tumbo en tumbo como le tocó a él: andariego, recoja un día café, otro algodón. "Toca madrugar para coger la mota cargada de rocío de la mañana; así pesa más", me contaba.

Yo, convertido en un hombre que presiente los peligros y se escabulle a tiempo como hacen los animales.

Yo, parado frente a un espejo mirándome vestido con camisa de manga larga, mermándome la barba con tijera, como lo hacía él.

Yo, cargando todo el día un bolso con las cosas importantes: un espejo, una peinilla, cigarrillos y una Biblia pequeñita para rezar el salmo $91^{77}$, como lo hacía

\footnotetext{
77 “Tú que vives al amparo del Altísimo y resides a la sombra del Todopoderoso, di al Señor: 'Mi refugio y mi baluarte, mi Dios, en quien confío'. Él te librará de la red del cazador y de la peste perniciosa; te cubrirá con sus plumas, y hallarás un refugio bajo sus alas. No temerás los terrores de la noche, ni la flecha que vuela de día, ni la peste que acecha en las tinieblas, ni la plaga que devasta a pleno sol...". (Recuperado de: http://bit.ly/1Slkgck).
} 
mi tío cuando se sentía desprotegido.

Sí, como él.

\section{Paratextos destacados}

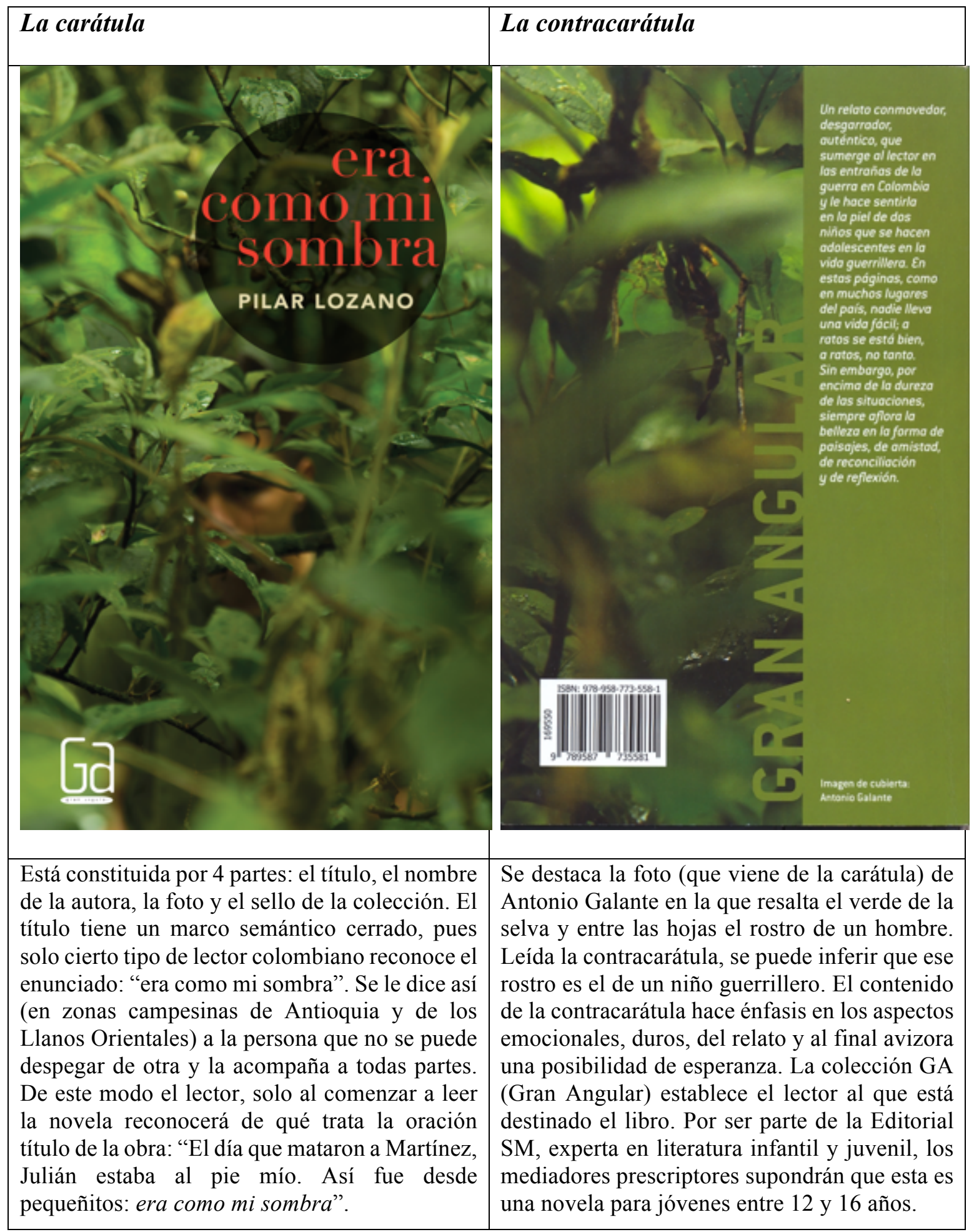




Información sobre la autora
Pilar Lozano nació en Bogotá. Es periodista, escritora
de literatura infantil y juvenil, promotora de lectura y
escritura. Ha publicado dieciocho libros, entre ellos el
muy conocido Colombia, mi abueloy yo, Así vivo yo y Crecimos en
la guerra.
Durante más de veintidós años fue corresponsal inde-
pendiente, en Colombia, del diario El País de España. Reco-
rrió todo el país como periodista y ahora lo sigue haciendo
como promotora de lectura y escritura. Es escritora aso-
ciada de la Red Nacional de Talleres de Escritura Creativa,
Relata.




\section{FRAGMENTO DE LA OBRA}

Nueve

En el combate también fuimos uña y mugre. Julián era bueno haciéndome la segunda, pegado como mi sombra. Solo, creo, no hubiera hecho nada. ¡Con esa forma de ser él, tan atolondrado!

Por eso, pienso, jamás nos separaron. A ninguno de los duros se le ocurrió siquiera mandarnos a operativos distintos o trasladarnos al uno sin el otro. Fuimos una llave.

Y confieso sin remilgos: nos gustaba el combate. En el entrenamiento y en los enfrentamientos, siempre nos destacamos. Él maniobraba mejor, ya fuera avanzando de frente, hacia atrás, de lado, retrocediendo.

Cuando llegaba la hora de pelear, brincábamos en una pata. Eso sí, desde que tuviéramos buen armamento. Al comienzo da cosquilleo pero, luego de sonar el primer tiro, pasa; uno se afiebra.

Yo tenía algo muy claro: uno puede ser muy pelión, pero no falta que por ahí una bala lo coja y lo vuelva nada. Eso se lo hice entender de entrada al Julián.

Temía quedar con las piernas partidas, sin un brazo... Prefería, mil veces, un tiro en la frente.

Llevaba siempre conmigo los papeles. Como los perdí recién llegado, cargaba en el bolsillo un laminado 56 
con el nombre mío, el número telefónico de un amigo del pueblo al que podían llamar y el nombre de mi mamá. Me encogía pensar que mi cuerpo quedara tirado, sin cristiana sepultura.

A Julián lo obligaba a mostrarme su tarjeta de identidad antes de salir a pelear.

Y salíamos con una idea fija en la cabeza: quitarle el fusil al chulo para adueñarnos de él, para ir cogiendo confianza. El arma del enemigo, aprendimos, es un trofeo. Es el reto, el objetivo. Como muchos pelados lo toman como un juego, brincan de la vida a la muerte sin siquiera darse cuenta.

En el entrenamiento nos animaban:

$-¿$ Quieren un fusil Galil bonito, pata corta? ¡Tienen que ganárselo!

A un pelado le venden fácil esa idea. Echábamos pa' delante sin pensar que arriesgábamos la vida. Éramos fáciles de encarrilar, funcionábamos como relojes bien afinados.

Terminamos creyendo que sin el fusil no éramos nada. Sin él nos sentíamos desnudos, achicados, desamparados. Por eso cuando a Manuel le ocurrió lo que le ocurrió, Julián llegó a preocuparme.

Un día entramos a un caserío en plan de hostigar el puesto de policía. No sé por qué, al comandante le dio por dejar a Manuel en la retaguardia, vigilando al lado del cementerio. Lo alejaron del combate; desde ese sitio no era posible hacer tiros. 
¡Me imagino la frustración tan tremenda! Regresó al campamento rebotado, alegó más de la cuenta. Le quitaron el fusil y lo mandaron de patrullero. Es como estar en el abismo y que llegue otro y lo empuje.

La única vez que Julián cuestionó la decisión de un mando. Duró días huraño, cabizbajo. Entendí el mensaje de sus gestos, de su silencio. Me asusté. Tuve una certeza: no iba a aguantar la humillación si por alguna razón le quitaran el arma. En el pueblo siempre tuvo fama de ser un bueno para nada; sin estudio, sin trabajo fijo, apenas servía para los mandados. Allá despertaba admiración por ser como era de arriesgado en el combate. Combatía parado, como pocos.

Del tiempo que estuvimos juntos allá, lo que más nos llegó a gustar fue salir a pelear al mando de El Calvo. Él no ponía diferencias: todos hacíamos lo mismo; todos cuidando a todos; era la chimba. Si podía, la víspera de un ataque programado - una emboscada, una toma, un asalto, un retén-compraba lo necesario para un piquete: carne, cervezas, guarapo.

Era su pensar: que las últimas horas la pasaran bien los que iban a morir. Al amanecer nos despedíamos con abrazos apretados, con palmadas en la espalda, con un "nos vemos luego, pelado". Si volvíamos completos, pues bien. El que no regresaba, pues... ¡qué se podía hacer!

Pero nos embejucaba salir con mandos que sin manejar una zona, ni saber cómo operaba el ejército, mandaban a los muchachos adelante. Ellos se quedaban atrás, 
bracicruzados. Comenzaba el combate y se escondían. No ayudaban a nadie.

Eso me sacaba la rabia. La descargaba lanzando con furia piedras al aire.

¡Con poca munición mandaban muchachos al frente! Aventarlo a uno a pelear así es como mandar ganado al matadero. Yo vivía reprochando a los jefes esa actitud. Una vez lo hablé en voz alta:

-A ustedes los tiraron a que los mataran - dije recio al pasar al lado de un grupo que logró escapar de milagro de las balas enemigas.

Uno de los manes se desmoralizó. Me echaron la culpa y me llamaron a cuentas. La falta: desprestigiar al mando. Cargué leña y cavé trincheras varios días.

Yo, cuando tuve poder, actué distinto. Ubicaba a mis muchachos y luego buscaba dónde cubrirme. Es cuestión de conciencia, creo. Es como dar paso a las ambulancias en medio de un retén. Los actos humanitarios los hace uno porque le nace, no porque de arriba den la orden.

Aprendí a utilizar la autoridad pero nunca para maltratar. Eso sí: toca ser un poco duro, mostrar don de mando. O si no, se pierde poder, se la montan a uno, le soplan los mocos, como decía mi tío.

Cuando veía un chino con flojera, si lo sorprendía en una falta, le ordenaba:

- ¡Necesito para el mediodía tres viajes de leña! Los pica, los carga, los trae y se los entrega al ranchero.

Así despertaban, dejaban esa pereza, ese desgano. 
Reunía a mis hombres y mandaba a alguno:

— ¡Lleve tinto al tercer puesto de guardia! Si se ponía altanero y alegaba que quedaba muy lejos, lo miraba fijo y ordenaba con una voz gruesa que hasta yo me la creía:

— ¡Lleve tinto al quinto puesto!

Ese sí quedaba lejísimos. Si volvía a la renegadera: que no sé qué, que sí sé cuándo, le daba la espalda, sacaba el cuaderno, el de anotar las faltas, y haciéndome el tontarrón le soltaba:

-Si no quiere, no vaya.

Santo remedio. Contestaba apurado:

-No, no, tranquilo, yo voy.

Pero cuando se trataba de pelear, me portaba de igual a igual con mis hombres. Y Julián siempre estuvo ahí sirviéndome de escudo, dispuesto a dar la vida para protegerme.

Y se arriesgó más de la cuenta.

Un día tenía a cargo cuatro combatientes: Daniela, Christian, Rodrigo y Julián. Íbamos recochando cuando vimos al enemigo bajando por un camino. Ni manera de esquivarlos. Estábamos condenados a encontrarnos sin saber dónde ni en qué momento.

Pensé: "Esperan para totiarnos, como perros al acecho." Yo ubiqué a los míos. A Christian lo dejé abajo, en la primera curva del camino. A Julián le ordené:

- Métase usted acá. Y señalé unos matorrales.

A la muchacha la dejé escondida más adelante. Yo seguí avanzando. Cuando me di cuenta, Julián iba detrás mío. Así fue siempre: si olía el peligro, no se despegaba. 60 
Unas curvas más adelante vi clarito al primero: venía de frente. Lo paré a plomo. Julián me cubrió porque desde arriba del barranco empezó la lluvia de balas: tata-ta-ta-ta.

Yo estaba embalado. Era él o yo, jverraco!

Pero mucho más verraco ver caer a un desarmado. Una vez nos ordenaron a Julián, a Efraín, a Julio y a mí ajusticiar a un campesino. Alguien lo acusó de ser sapo, de irle con cuentos al ejército.

Cuando nos vio se sentó entre unas matas llenas de flores. Se achicó, suplicaba con sus ojos desorbitados. Movía los labios sin lograr pronunciar nada. Se le murieron primero las palabras.

Me sentí infeliz, el más cobarde de los cobardes. Quedé confuso, aturdido. Mantuve despierto hasta muy tarde. Esa noche hablé con mi tío, alma bendita. Le pregunté:

$-{ }$ Usted, allá en el cielo, piensa que esto es hacer justicia con los pobres? ¿Qué tiene que ver esto con su sueño de entregar a los pobres tierras, justicia, saberes?

Cómo me hubieran servido sus respuestas. Y la respuesta a otra duda que me atormenta desde niño:

$-{ }_{i}$ Cuando uno se muere a dónde va?

Luego soñé con el velorio de mi tío. El cuerpo desnudo cubierto con una sábana, sobre una mesa, a lado y lado dos velones montados sobre canecas y ahí pegados nosotros, los deudos: la abuela, mi mamá, la gente que lo quería en el caserío. 
Pero el sueño se convirtió en pesadilla cuando el cuerpo sobre la mesa no era el de mi tío sino el del campesino ajusticiado y a lado y lado, mirándome con ojos ensangrentados de la rabia, la viuda, los huérfanos.

Me desperté sobresaltado. "En la guerra cada cual llora a sus muertos", me hubiera dicho mi tío para calmarme. Envidié a Julián: con esa forma de ser jamás se cuestionó nada.

Desde ese día, órdenes que había cumplido sin remordimientos, ni consideraciones, comenzaron a inquietarme. 


\section{ANÁLISIS CRÍTICo}

A diferencia de Patricia, la joven de origen burgués, protagonista de Paso a Paso, el narrador de Era como mi sombra es un niño guerrillero, en las antípodas de la pirámide social, de origen campesino y nacido en la pobreza extrema. No aparece con nombre en la novela. Su anonimato es el de por lo menos 20.000 niños que fueron reclutados por los grupos armados entre 1990 y 2010, de los cuales por lo menos 3.000 murieron en combates ${ }^{78}$. El niño guerrillero no es, incluso, un guerrillero con fama: no es como Tirofijo, ni como los que estuvieron de negociadores en La Habana ${ }^{79}$.

El niño guerrillero (como lo denominaremos en adelante) nació en un pueblo -"un caserío" se nos dice en el capítulo 2- "de una sola calle larga". A lo largo de los 13 capítulos de la novela (de sus 86 páginas) se nos narra en primera persona ${ }^{80}$ su vida desde los 8 años hasta los 16. En el capítulo 1, mientras va por el campo con su amigo de siempre, Julián, lo vemos contemplar un asesinato:

Fue un viernes muy de mañana. Bajábamos dando brincos por la loma. Íbamos a ayudar a arriar un ganado arisco. Un grito nos frenó en seco:

_ ¡Martínez! ¡Alto ahí!

Martínez subía por la misma pendiente. Vimos sus ojos desorbitados. El traquetazo de los tres tiros, el sonido sordo del cuerpo al desplomarse y la mancha roja empapando su uniforme verde... todo ocurrió en un solo instante. (Lozano, 2015, p. 3).

Esta apertura de la novela le sirve de inmediato a la autora de la novela, Pilar Lozano, para poner a sus lectores (esencialmente jóvenes de entorno urbano) ${ }^{81}$ en conocimiento de una situación que para muchos es desconocida: la violencia en el entorno rural a causa del conflicto armado que vive Colombia desde los años 60 del siglo pasado. El estilo de exposición no es costumbrista (no se celebra nada de la supuesta belleza y tranquilidad del

\footnotetext{
${ }_{79}^{78}$ Estos datos son aproximados y resultan del análisis expuesto en la sección Contexto histórico (p. 98-112).

${ }^{79}$ Tirofijo aparece como personaje secundario en la novela Caín (1969), de Eduardo Caballero Calderón, y en varias de las obras de ficción de Arturo Alape.

${ }^{80}$ Narrador interno "autodiegético", lo denomina Genette (ver nota 83).

${ }^{81}$ Era como mi sombra aparece en la Colección Gran Angular de Ediciones SM Colombia, dirigida a lectores entre 12 y 16 años. Ver nota en la explicación de la contracarátula, p. 120.
} 
"mundo campesino"), sino de un realismo seco y directo que ha sido calificado de documental por el jurado del Premio Fundación Cuatrogatos 2016, que lo ha incluido dentro de los 20 mejores libros en lengua española del año anterior:

La problemática de la participación de menores como soldados en los conflictos bélicos es abordada de forma realista, casi documental, en esta novela que narra la experiencia de dos adolescentes de un pequeño pueblo campesino. A causa de la falta de oportunidades y horizontes, ambos toman la decisión de incorporarse a la guerrilla en Colombia y conocen en carne propia el violento universo de la guerra. Narrado en primera persona, con una voz de gran autenticidad, este conciso y potente relato impacta por su humanismo, su homenaje a la amistad y su reflejo de una dramática y dolorosa realidad social. (Cuatrogatos, 2016, p.15).

En la línea narrativa realista de novelas latinoamericanas para jóvenes que se centran en conflictos bélicos, como La composición (2000) de Antonio Skármeta y Alfonso Ruano, Las visitas (2001) de Silvia Schujer, El mar y la serpiente (2006) de Paula Bombara, Lozano asume contar la historia de un niño que solo ha conocido el mundo de la guerra y en la que son actores centrales los grupos guerrilleros de izquierda (sobre todo las Farc y el Eln), los paramilitares de derecha (de las AUC) y el Ejército y la Policía, como representantes de la fuerza pública del Estado ${ }^{82}$.

Lozano conoce del tema porque desde hace más de 20 años ha investigado la problemáticas de los niños y jóvenes, que fueron reclutados por los ejércitos ilegales en la demencial guerra que en Colombia sobre todo se agudizó entre 1990 y 2000. Como aparece en el perfil biográfico, ella es fundamentalmente periodista, y como reportera, sobre todo del diario $\mathrm{El}$ País de España, debió recorrer el país informando sobre la guerra. A una mujer de su talante ético y político no le iba a ser extraño ver el drama de estos niños y jóvenes, a quienes los grupos armados les habían quitado su niñez y los habían involucrado en terribles acciones de

\footnotetext{
${ }^{82}$ La misma pregunta se la hace la premio Nobel de Literatura 2016, la bielorrusa Svetlana Alexiévich: “¿Que cuál es mi primer recuerdo de la guerra? Mi angustia infantil en medio de unas palabras incomprensibles y amenazantes. La guerra siempre estuvo presente: en la escuela, en la casa, en las bodas y en los bautizos, en las fiestas y en los funerales. Incluso en las conversaciones de los niños”. Recuperado de: http://bit.ly/1ZQTF7Z
} 
guerra, violando los diferentes tratados internacionales y nacionales que prohíben la presencia de niños soldados.

Lozano recogió sus crónicas de dos décadas sobre estos jóvenes guerrilleros y paramilitares en Crecimos en la guerra (2014). El libro tuvo algún eco en los medios de prensa ${ }^{83}$, debido a los hechos terribles que contaban estos niños y muchachos, ahora desvinculados del conflicto armado y en proceso de resocialización en hogares establecidos por el Instituto Colombiano de Bienestar Familiar. Pero como lo aclara Lozano en una entrevista ${ }^{84}$, aquellos hechos que le habían dejado perpleja exigían ser recontados y asumidos de otra forma para que quedaran como testimonio de la dimensión de la tragedia: a través de la literatura.

Pero llegar allí implicó andar sobre su propia biografía. Pilar Lozano es promotora de lectura y coordina talleres de literatura para niños, jóvenes y docentes, y además hace parte de Relata (Red Nacional de Talleres de Escritura Creativa) en los que ayuda a escritores novatos a perfeccionar sus manuscritos. Es también autora de libros infantiles desde 1994, cuando publicó un libro que hoy se considera de referencia en la literatura infantil colombiana: Colombia, mi abuelo y yo.

Esta formación le hizo tomar confianza al momento de decidir escribir un novela sobre los niños guerrilleros. Sentía que "semejante desconocimiento del problema" en el país era grave y no podía callarse ${ }^{85}$. Asumió, entonces, escribir un relato de ficción ${ }^{86}$.

Aquí entramos en un un campo interesante, pues observamos en acción un procedimiento relativamente reciente utilizado por los periodistas que se atreven a dar el paso a escritores de literatura -cruzar esta frontera compleja- y es lo que técnicamente se denomina "canibalizar" el propio material narrativo. Dos diccionarios nos ofrecen una definición precisa del concepto:

\footnotetext{
${ }_{83}^{83}$ Cfs. la reseña del libro escrita por el sacerdote Javier Darío Restrepo. Recuperado de: http://bit.ly/2134eW3.

${ }^{84}$ Entrevista a Carlos Sánchez Lozano, podcast, minuto 25. Ver Anexo, p. 214.

${ }_{86}^{85}$ Entrevista a Carlos Sánchez Lozano, podcast, minuto 2. Ver Anexo, p. 214.

${ }^{86}$ Hay que aclarar -siguiendo a González (2014, p. 91)- que "la denuncia no es uno de los objetivos fundamentales de esta literatura finisecular, más que eso es la reconstrucción y la exposición de un problema que atañe a la sociedad en general y que repercute directamente en los niños. Por esa misma razón trata de contenerse en decir nombres exactos y hechos concretos. Son libros que intentan recoger ejemplos de la realidad colombiana, ante lo cual el niño lector puede tener preguntas cuya respuestas son respondidas o sugeridas a través de la literatura".
} 
canibalizar

Reutilizar masivamente los componentes de cierta cosa para producir otra.

Utilizar las piezas en buen estado de un equipo, herramientas o vestimentas inutilizables o fuera de uso, para construir algo nuevo ${ }^{87}$.

En efecto Pilar Lozano canibaliza, reutiliza sus crónicas periodísticas de Crecimos en la guerra (2014) y transforma una parte de este material en una novela: Era como sombra (2015). Como lo veremos más adelante, aprovecha la información que los jóvenes exguerrilleros y exparamilitares le dieron en varias entrevistas y les da un tratamiento literario. ¿Por qué lo hace? ¿Y cómo? ¿Y cuál es el el resultado? ¿Gana el periodismo o la literatura? Esta metamorfosis del material es, desde todo punto de vista, tanto formal como de lenguaje, compleja. En nuestra opinión, sale victoriosa la literatura (y la obtención del reconocido Premio Cuatrogatos es una prueba de ello), y muestra cómo la intervención y el diálogo con el editor ${ }^{88}$, puede desempantanar un rico material narrativo de origen periodístico y darle un horizonte estético, con carácter de permanencia en el tiempo.

Lozano, desde nuestra perspectiva, hace una canibalización que sigue con acierto tres reglas del lenguaje novelesco:

- La condensación narrativa.

- El triunfo de la verdad ficcional frente a la verdad real.

- La construcción del héroe.

La condensación narrativa fue explicada de manera sencilla por el romanista alemán Hugo Friedrich (en Tres clásicos de la novela francesa, 1969) al analizar los aportes a la novela moderna que hicieron Stendhal, Balzac y Flaubert. Puntualmente señala:

La novela puede abarcar toda una vida o limitarse a un solo día, como también comprender toda una generación o toda una nación $\mathrm{y}$, por su posibilidad intrínseca, toda la humanidad, y hasta puede o podría pasar desde la vida limitada

\footnotetext{
${ }^{87}$ Recuperado de: http://bit.ly/1L17SBH; http://bit.ly/1KfJc2w

${ }^{88} \mathrm{La}$ autora reconoce (en la entrevista a CSL, podcast minuto 9:50. Ver Anexo, p. 214.) que el diálogo y las sugerencias de María Fernanda Paz-Castillo, editora jefe del área de literatura infantil y juvenil de Ediciones SM Colombia, cumplieron un papel determinante en la reconstrucción y progresivo cambio del manuscrito durante 3 años de escritura de la novela.
} 
en una habitación hasta los procesos cósmicos (...). Además puede jugar en todas partes, y todo el tiempo que desee, y dedicarse todo el tiempo que quiera, en una externa continuidad del narrar, a las amplitudes espaciales y temporales del acaecer. (Friedrich, 1969, p. 14).

En 13 capítulos la autora resume ocho años en la vida de este muchacho. Para hacerlo organiza una cronología calculada que parte de un crimen (capítulo 1) cuando el narrador tiene aproximadamente 8 años y termina con el autodescubrimiento (capítulo 13) a los 16, cuando ya, convertido en adolescente, se ha fugado de la guerrilla y resuelve iniciar una nueva vida. Cada capítulo, como se observa en el esquema 13, presenta paso a paso, momentos en que se reconstruye la vida del niño guerrillero. La condensación permite que solo se nos cuente lo esencialmente necesario a efectos de percibir la inevitable entrada del protagonista en la guerrilla, su progresivo agotamiento y la posterior decisión de desertar. El efecto es el de un álbum fotográfico que nos resume en 13 fotos la vida de un ser humano. Los capítulos van entre las 4 y las 8 páginas y siempre giran alrededor de una anécdota central que constituye el tema.

Hay un capítulo dedicado al tío Pedro (héroe y referente para el niño), a la mamá, a su gran amigo Julián, a la vida escolar y a la profesora Elvira (otro de sus referentes adultos), al primer combate ya dentro de la guerrilla, a la pobreza en el pueblo, a una niña guerrillera (probablemente uno de los capítulos más dolorosos), a la cotidianidad en el frente armado y las mentiras de los revolucionarios, a su primer noviazgo serio, y a la fuga. Aunque el libro no trae Índice, a este lo remplaza la sistematización de la historia en grandes momentos en la vida del héroe. 


\section{Esquema 13. Análisis de la secuencia temporal de Era como mi sombra}

\begin{tabular}{|c|c|c|c|c|c|c|c|c|c|c|c|c|}
\hline \multicolumn{13}{|c|}{ Capítulos } \\
\hline 1 & 2 & 3 & 4 & 5 & 6 & 7 & 8 & 9 & 10 & 11 & 12 & 13 \\
\hline \multirow[t]{3}{*}{$\begin{array}{c}\text { Primer } \\
\text { asesinato }\end{array}$} & $\begin{array}{c}\text { Vida } \\
\text { familiar }\end{array}$ & $\begin{array}{l}\text { Influencia } \\
\text { del tio } \\
\text { Pedro }\end{array}$ & $\begin{array}{l}\text { Asesinato } \\
\text { del tio } \\
\text { Pedro }\end{array}$ & $\begin{array}{c}\text { Oferta } \\
\text { para } \\
\text { entrar a la } \\
\text { guerrilla }\end{array}$ & $\begin{array}{c}\text { La } \\
\text { profesora } \\
\text { Elvira }\end{array}$ & $\begin{array}{c}\text { Decisión } \\
\text { entrar a } \\
\text { la } \\
\text { guerrilla }\end{array}$ & $\begin{array}{c}\text { Vida } \\
\text { cotidiana } \\
\text { en la } \\
\text { guerrilla }\end{array}$ & $\begin{array}{c}\text { La } \\
\text { guerra. } \\
l^{\circ} \\
\text { criticas } \\
\end{array}$ & $\begin{array}{l}\text { "Paras" en } \\
\text { el pueblo. } \\
\text { Muerte } \\
\text { abuela }\end{array}$ & $\begin{array}{c}\text { Matilde, } \\
\text { niña } \\
\text { guerrillera } \\
2^{\circ} \text { critica }\end{array}$ & $\begin{array}{c}L a \\
\text { deserción }\end{array}$ & Nueva vida \\
\hline & & & & & $\Leftrightarrow$ & & & & & & & $P$ \\
\hline & & & & & $\begin{array}{c}\text { Manejo } \\
\text { computador }\end{array}$ & & & & & & & $\begin{array}{l}\text { Viajes de } \\
\text { guerrillero }\end{array}$ \\
\hline$\Leftrightarrow$ & $\Leftrightarrow$ & 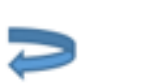 & 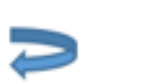 & $\Leftrightarrow$ & $\Leftrightarrow$ & & & & $P$ & & $\geqslant$ & 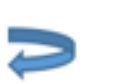 \\
\hline \multirow[t]{3}{*}{$\begin{array}{l}\text { Pata del } \\
\text { arcoiris }\end{array}$} & $\begin{array}{c}\text { Cargar } \\
\text { fusil } R \text { - } \\
15 \\
\end{array}$ & $\begin{array}{l}\text { Aclaración } \\
\text { asesinato } \\
\text { Martinez }\end{array}$ & $\begin{array}{l}\text { Navidad de } \\
\text { los niños }\end{array}$ & $\begin{array}{l}\text { Culebrear } \\
\text { en el piso }\end{array}$ & $\begin{array}{c}\text { Jefe de } \\
\text { cuadrilla }\end{array}$ & & & & $\begin{array}{l}\text { Evocación } \\
\text { de la mamá }\end{array}$ & & $\begin{array}{l}\text { Deseo de } \\
\text { fugarse }\end{array}$ & $\begin{array}{c}\text { Ataque } \\
\text { avión del } \\
\text { Ejéreito } \\
\end{array}$ \\
\hline & & & & & $\Leftrightarrow$ & & & & & & & $\geqslant$ \\
\hline & & & & & $\begin{array}{c}\begin{array}{c}\text { Profesora } \\
\text { contra la } \\
\text { guerra }\end{array} \\
\end{array}$ & & & & & & & $\begin{array}{l}\text { Asesinato } \\
\text { de Julián }\end{array}$ \\
\hline & & & & & & & & & & & & $\Rightarrow$ \\
\hline & & & & & $\Rightarrow$ & \multicolumn{2}{|c|}{ Narración lineal } & & & & & \\
\hline & & & & & $P$ & \multicolumn{2}{|c|}{ Flash back } & & & & & \\
\hline & & & & & $\Leftrightarrow$ & \multicolumn{2}{|c|}{ Flash forward } & & & & & \\
\hline
\end{tabular}

Nota: Elaboración propia, pero se adapta del esquema, muy útil, realizado por Proyecto de Estudio Visual Data (Granta I, 2014, p. 141).

Dos recursos más facilitan la condensación narrativa: el primero, es el manejo equilibrado de los momentos de tensión dramática (picos y bajos $^{89}$ ). El capítulo de la fuga-el más tenso- es el penúltimo, cuando ya el lector espera una resolución del personaje y le ha sido mostrado todo el arco de la ilusión a la desesperanza ${ }^{90}$. El segundo, es que la autora si bien privilegia el tiempo lineal de narración, acude puntualmente al flash back (ir hacia atrás) y al flash forward (ir hacia delante). Estos recursos enriquecen la narración pues permiten que el protagonista se devuelva en el tiempo cuando quiere recuperar algo del pasado que considera

\footnotetext{
${ }^{89}$ Los picos recogen los momentos más dramáticos de la historia, y los bajos aquellos en los que la protagonista hace análisis o reflexión de lo sucedido, o relata anécdotas intermedias que preparan a un nuevo pico del conflicto.

${ }^{90}$ Me tomo yo mismo como ejemplo de lector frente a los momentos de tensión emocional: leí la novela de 86 páginas en 90 minutos, con breves pausas para reflexionar sobre hechos narrados en el relato.
} 
un patrimonio espiritual y moral (la influencia de su tío Pedro, cap. 4) o, al contrario, ofrezca avances de situaciones clave que vivirá durante su época de guerrillero (el manejo del computador que le enseñó la profesora Elvira, cap. 6).

En relación con el segundo procedimiento de "canibalización" que hemos señalado atrás, el triunfo de la verdad ficcional frente a la verdad real (esquema 14) vale la pena hacer varias aclaraciones con respecto a Era como mi sombra. Mario Vargas Llosa que ha introducido estos conceptos -en su particular modo de aportar a las mímesis que antes habían propuesto Aristóteles, Ricoeur y Auerbach ${ }^{91}$-, pregunta y a su vez responde:

¿Qué diferencia hay, entonces, entre una ficción y el reportaje periodístico un libro de historia. No están compuestos ellos de palabras? ¿No encarcelan acaso en el tiempo artificial del relato ese torrentes sin riberas, el tiempo real? La respuesta es: se trata de sistemas opuestos de aproximación a lo real. En tanto que la novela se rebela y transgrede la vida, aquellos géneros no pueden dejar de ser sus siervos. La noción de verdad o mentira funciona de manera distinta en cada caso. Para el periodismo o la historia la verdad depende del cotejo entre lo escrito y la realidad. A más cercanía, más verdad, y, a más distancia, más mentira. (...). En cambio, la novela no depende de eso. ¿De qué entonces? De su propia capacidad de persuasión, de la fuerza comunicativa de su fantasía, de la habilidad de su magia.

Toda buena novela dice la verdad y toda novela mala miente. (Vargas Llosa, 2015, p. 20).

La novela de Pilar Lozano se basa en "hechos verdaderos", pero esa ficcionalización, para ser lograda y constituirse en "verdad novelesca" (y alcanzar lo que Vargas Llosa llama "decir la verdad"), requiere de la consolidación de un campo de verosimilitud que no se quede en la mera enumeración de hechos (la "realidad abstracta", dirá Hegel en la la Introducción a la Fenomenología del Espíritu) ${ }^{92}$, sino que los supere a través de un acto estético que sea trascendente. Friedrich (1969), bien lo resume:

\footnotetext{
${ }^{91}$ Aristóteles, Poética, 2004; Auerbach, Mímesis, 1959, 2014; Ricoeur, Tiempo y narración, 2004.

${ }^{92}$ Lo abstracto es "lo concreto que no se revela, la expresión de la insuficiencia, lo que carece de desarrollo para el Todo". (Hegel, 2006, p. 190).
} 
La novela satisface el alto requisito de la epopeya, a saber, la totalidad de una concepción del mundo y de la vida cuyo múltiple material y contenido aparece dentro del dato individual que ofrece el punto central para el todo. (p. 20).

\section{Esquema 14. Mímesis, según Vargas Llosa}

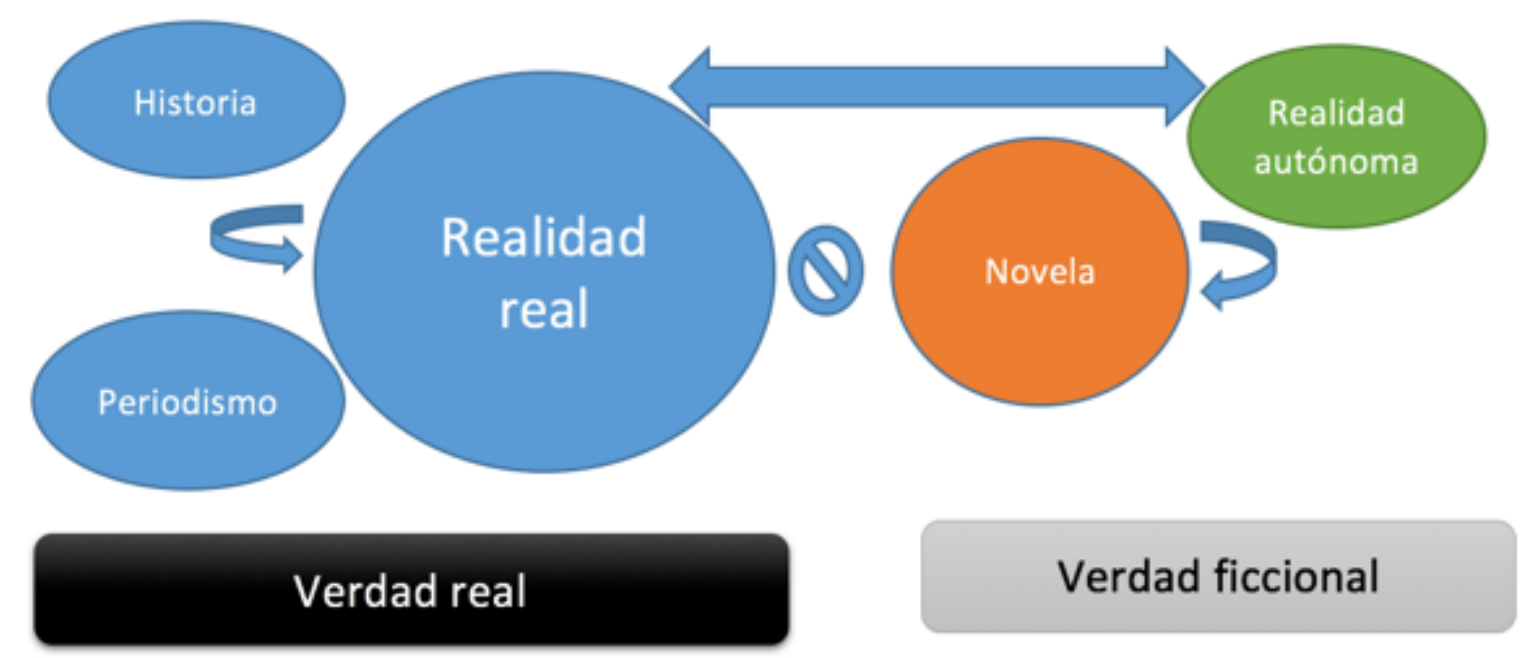

Nota: Elaboración propia.

En Era como mi sombra ese "dato individual" se convierte en el "punto central para el todo" mediante una estrategia discursiva, que llamaremos "expansión narrativo-estética". Observemos primero un ejemplo. Yair ${ }^{93}$ es uno de los exguerrilleros que Pilar Lozano ha entrevistado en su libro de crónicas Crecimos en la guerra (2014). La periodista cuenta de él:

[1] Yair estudiaba en la mañana y trabajaba en lo que fuera en la tarde, al lado de Andrés, un amigo un poco mayor que él, [2] pero mucho más pobre, tanto que jamás pudo estudiar. [3] En las noches, muchas veces, acompañaba al tío al billar.

[4] Yair se encargaba de cuidar el arma. (Lozano, 2014, p. 160)

Ahora obsérvese el proceso de "canibalización” al aprovechar el fragmento y ficcionalizarlo: la oración 4 de la crónica se convierte en un extenso párrafo del capítulo 3 de la novela:

Como ya sabía su secreto, mi tío empezó, poco a poco, a encomendarme favores.

\footnotetext{
${ }^{93}$ El nombre es inventado por seguridad.
} 
Si había policía en el pueblo, yo me encargaba de entrar las armas: escondía la pistola debajo del ala de una gallina o me inventaba otro truco. A él lo requisaban y no le encontraban nada. Yo lo esperaba más abajo y se la entregaba. La primera vez tuve tiempo de sobra; me puse a mirar la pistola por lado y lado. Hasta traté de quitarle un mugre que la afeaba. Era finita, pero muy pesada. (Lozano, 2015, p. 18).

De ese modo, en la novela Era como mi sombra, la "expansión narrativo-estética" se cumple así:

\section{Esquema 15. Expansión narrativa en Era como mi sombra.}

\begin{tabular}{|c|c|c|c|}
\hline Oración 1 & Oración 2 & Oración 3 & Oración 4 \\
\hline 25 palabras & 9 palabras & 10 palabras & 7 palabras \\
\hline & & & \\
\hline Capítulos 1,6 & Capitulos 2, 6, 8, 12 & Capitulo 4 & Capítulo 3 \\
\hline 8 páginas & 4 páginas & 2 páginas & 1 página \\
\hline
\end{tabular}

Nota: Elaboración propia.

Obsérvense los cambios. En la crónica el narrador es externo (la periodista, Pilar Lozano); en la novela el narrador es interno (primera persona, el niño guerrillero). En la crónica, sumariamente, se detalla el "dato individual"; en la novela se ofrece el "punto central del todo": se describe lo que pasa con el arma que el tío Pedro le ha encargado cuidar al niño narrador. Hay un cambio radical en la presentación de los hechos en la novela: el niño es usado por el tío para evadir las requisas de la policía, el niño burla la autoridad, fortalece su confianza y amistad con su tío y de paso tiene la oportunidad de comprobar que le gustan las armas. La oración en la crónica tiene 7 palabras; el fragmento de la novela, 90 palabras. Se nos da un contexto del valor de la "lealtad" y el "amor" y la confianza (por decirlo así) que tiene el tío en el sobrino. Hablamos de "fraternidad familiar", así esta se presente en un marco de violencia y zozobra.

Desde luego que esta "expansión narrativo-estética” no se basa exclusivamente en el número de páginas, sino en un discurso que no es otro que el los formalistas rusos y checos han 
llamado "literariedad" 94 y que se produce en el texto literario gracias a una mediación lingüística, discursiva, estética, explicada en detalle por Jakobson en su famoso análisis "Lingüística y poética", incluido en Ensayos de lingüística general (1985). En Era como mi sombra triunfa la verdad ficcional sobre la verdad real. Lo que antes era anécdota en la narración periodística, ahora es símbolo, arquetipo, en la narración ficcional.

Por último, nos enfocaremos en el tercer aspecto de la "canibalización": la construcción del héroe. Lukács en Teoría de la novela $(1920,2010)$ desarrolló una propuesta de este héroe, que nos interesa aplicar al personaje protagónico de Era como mi sombra. Según Lukács, “en sentido estricto, el héroe de la epopeya no es nunca un individuo" (2010, p. 63). Si ello es así, lo que Lozano ha hecho en nuestra opinión, entonces, es fundir las voces de los jóvenes que entrevistó para sus crónicas periodísticas (Yair, María, Fabián, Julio, Sandra) y los convirtió en una sola voz totalizante: el narrador sin nombre, el niño guerrillero, que es el héroe de su novela. Todos los niños, niñas y jóvenes guerrilleros están contenidos en ese personaje que nos narra su dramática vida en Era como mi sombra. Él es una suma de todo el dolor que sufrieron los 18 mil niños de los que habla una investigación que han hecho parte de los grupos armados ilegales ${ }^{95}$. Con ello, Lozano se alinea con las víctimas (los menores de edad en los grupos armados no son victimarios, sino víctimas $)^{96}$ y esgrime su intención de denunciar - desde una perspectiva literaria e intelectual comprometida- a los victimarios (los reclutadores adultos $)^{97}$.

Obsérvese cómo Lozano aprovecho -canibalizó- esas voces y les dio autoridad literaria en la constitución del héroe (esquema 16):

\footnotetext{
94 "La literariedad es la propiedad por la que un discurso verbal entra a formar parte de la literatura". (2004, p. 182). La literariedad responde a la pregunta de Jakobson: “¿qué hace que un mensaje verbal sea una obra de obra?". Los conceptos de "ambigüedad", "polisemia" y "función poética del lenguaje" sostienen esa respuesta. En la teoría de las funciones jakobsoniana la "poética" es la que establece el predominio de la orientación hacia el mensaje en sí.

${ }^{95}$ Cfs. el Contexto histórico, p. 98-112-

${ }^{96}$ Sentencia de la Corte Constitucional No. 251 de 2008. Cfs. GMH, 2013, p. 86.

${ }^{97}$ Esto lo hace Lozano no en el marco de posturas ideológicas o partidistas de izquierda, sino desde la perspectiva de lo que el filósofo español Manuel Reyes Mate denomina "ética compasiva" (cfs. Reyes Mate, 2008). "Sabemos lo que somos cuando respondemos a la pregunta del otro, de ese otro ninguneado por la vida, la sociedad o la historia. No se trata, por tanto, a propósito de la compasión de hacer un favor al necesitado, sino de devenir uno mismo sujeto moral o, como se llama en la jerga cristiana, «prójimo». Ser prójimo es constituirse en sujeto moral y esto ocurre cuando nos aproximamos al caído". (p. 24).
} 
Esquema 16. Canibalización entre periodismo y literatura

\begin{tabular}{|c|c|}
\hline $\begin{array}{c}\text { Crónica periodistica "Nosotros fuimos } \\
\text { criados en la guerrilla" }\end{array}$ & Novela Era como mi sombra \\
\hline $\begin{array}{l}\text { Cuando [Yair] decidió volarse era jefe de } \\
\text { escuadra. Los comandantes lo alababan, le } \\
\text { decían que tenía madera para convertirse } \\
\text { pronto en un cuadro importante (...). "Salí } \\
\text { ardido con ellos. ¡Cuánto perdi de } \\
\text { juventud! Me arrepiento por los que } \\
\text { murieron". Desertó con Andrés. Subieron } \\
\text { tranquilos hasta un filo; llegaron a una } \\
\text { casa, pidieron un 'chance' a un jeep que } \\
\text { pasaba. (p. 164). }\end{array}$ & $\begin{array}{l}\text { Si miro para atrás y hago cuentas, desde el } \\
\text { segundo año de estar allá, de cuando en } \\
\text { cuando se me atravesaba la idea de } \\
\text { volarme. (...). } \\
\text { Ya íbamos lejos, lejos, por un camino todo } \\
\text { embarrado. Ya respirábamos tranquilos. } \\
\text { Nos sentíamos libres cuando oímos el } \\
\text { motor de un carro. } \\
\text { Nos seguían. Quedamos paralizados. Eran } \\
\text { ellos. "¿Dónde están esos hijueputas, } \\
\text { malparidos, para matarlos? - gritaban". (p. } \\
75,81 \text { ). }\end{array}$ \\
\hline $\begin{array}{l}\text { Otro compa fue el encargado de hacerle [a } \\
\text { María] un rosario de preguntas para la hoja } \\
\text { de vida: “¿Nombre? ¿Tiene tatuajes? } \\
\text { ¿Cicatrices? ¿Tiene familia o amigos en el } \\
\text { Ejército? ¿Su familia colabora con las } \\
\text { Farc?”... Cuando terminó, la mandaron a } \\
\text { bañar. (p.167). }\end{array}$ & $\begin{array}{l}\text { Un pitazo me despertó al otro día a las } \\
\text { cuatro de la madrugada. Luego apareció el } \\
\text { encargado de hacer las preguntas para la } \\
\text { hoja de vida: } \\
\text { — ¿Nombre? ¿Tatuajes? ¿Cicatrices? } \\
\text { ¿Tiene familia o amigos en el ejército? } \\
\text { ¿Algún pariente colabora con la guerrilla? } \\
\text { Cuando terminó, me mandó a la peluquería } \\
\text { y a bañarme. Me tusaron. (p. 44). }\end{array}$ \\
\hline $\begin{array}{l}\text { Los jefes le fueron cogiendo confianza [a } \\
\text { Julio]. Tiempo después un comandante le } \\
\text { preguntó: "¿Sabe manejar esto?", y le } \\
\text { mostró un portátil. Respondió que sabía } \\
\text { escribir y guardar archivos. Le entregó el } \\
\text { computador, una impresora pequeña y un } \\
\text { cargador... "La responsabilidad mía era } \\
\text { mucha". (p. 173). }\end{array}$ & $\begin{array}{l}\text { Allá me convertí en un duro. Estuve una } \\
\text { vez a cargo del computador del } \\
\text { comandante. Guardaba documentos, hacía } \\
\text { hojas de vida, metía los nombres de los que } \\
\text { ingresaban, los que morían o desertaban. } \\
\text { La responsabilidad mía era mucha. Sabía: } \\
\text { primero hacerme matar que entregarlo. (p. } \\
\text { 37). }\end{array}$ \\
\hline $\begin{array}{l}\text { Julio dice que "el verde atrae". "Yo llegué } \\
\text { a tener seis novias a la vez en una misma } \\
\text { vereda. El comandante se dio cuenta y me } \\
\text { tocó elegir. Las analicé y me quedé con la } \\
\text { más buenecita". (p. 179). }\end{array}$ & $\begin{array}{l}\text { Por eso con Julián entrábamos campantes } \\
\text { al caserío, en moto o a pie, y nos } \\
\text { quedábamos horas coqueteando frente al } \\
\text { colegio de mujeres. Uno, uniformado y } \\
\text { armado, tiene éxito; lo persiguen (...). Así } \\
\text { conocí a Mayerly. (p. 76). }\end{array}$ \\
\hline
\end{tabular}

Nota: Elaboración propia.

Desde luego que este héroe es problemático - en la jerga de Lukács- y cumple la regla establecida por el teórico húngaro de que "el individuo épico, el héroe de la novela, es producto de la extrañeza con el mundo exterior” (Lukács, 2010, p. 62). La epopeya del niño 
guerrillero -su problematicidad- consiste en que se rebela contra un destino dado. Si bien, a causa del contexto de pobreza extrema en que vive, de la carencia de oportunidades, de la presencia de los grupos armados en la zona donde está su familia, no puede huir de un destino casi establecido como un guion para los jóvenes de las regiones más humildes de Colombia y que han sufrido el conflicto armado en toda su intensidad, no acepta resignarse (como tal vez sí sucede con su amigo Julián) y asumir el destino de guerrero hasta el final. Contra la posibilidad de seguir combatiendo, matando, secuestrando se detiene y asume posiciones críticas. Si observamos el esquema 13 podemos verificar que en los capítulos 8, 9 y 12 aparece su distanciamiento explícito:

¿Y no es injusto que un niño que debe estar jugando y estudiando termine en la guerrilla o en los paramilitares? —le pregunté una noche estrellada a Julián. (p. $55)$.

Desde ese día, órdenes que había cumplido sin remordimientos, ni consideraciones, comenzaron a inquietarme. (p. 62).

Hasta que una noche de insomnio en la que sentí minuto a minuto la compañía de mi tío la vi clara: quería salir con vida de la guerra. Fue como si él me soplara la respuesta a tremenda encrucijada: había llegado el momento de dejar las armas. (p. 77).

Este carácter crítico de su personalidad proviene no solo de la educación y los consejos que le dio su tío Pedro ${ }^{98}$, sino esencialmente del apoyo que le brindó la profesora Elvira. Este personaje es interesantísimo y otra de las heroínas de la novela. “¿En qué fallé?” (p. 36) le pregunta ella con gran culpa cuando el niño le dice que se va a la guerrilla. Esta conciencia de maestra del modelo Escuela Nueva, que atiende a los niños de todos los grados, de primero a quinto de primaria en un solo salón, es única, un modelo ético de trabajo. El narrador nos dice que la maestra Elvira viaja en moto todos los días "desde el pueblo donde vivía con sus hijos, casi dos horas de ida y otras tantas de vuelta" (p. 36) y hace múltiples sacrificios por enseñar bien a sus estudiantes. Compra un mapa de Colombia de su propio bolsillo (la

\footnotetext{
98 "Si usted es estudiado, sabe las respuestas a todas las preguntas. No se quede bruto como yo, que por eso mantengo enredado. No se le ocurra nunca seguir el camino que tomé yo. Sólo una vez se le salió, sin querer, creo: 'Estoy en lo que estoy y nunca puedo salirme' Sí, él nunca me encaminó a la guerra”. (p. 30).
} 
Colombia que le dio la espalda a los niños más humildes del país), hace un computador de cartón (¡de cartón!) para explicarles las partes que lo componen, bajo el criterio de que "Ustedes no se pueden quedar atrás. Mientras llega uno de verdad, vamos a ensayar en este de mentiras" (p. 37). Seguramente mal pagada, sin apoyo de ningún estamento estatal para formarse mejor, sin recursos didácticos, sin libros, sin laboratorio, piensa que sacarlos adelante es lo que impedirá que se vayan para la guerra, que se vayan a integrar los grupos armados donde serán "carne de cañón".

El niño la evoca cuando ya está en la guerrilla como un modelo de lo que es ser humano comprometido con la sociedad y con los más pobres, y su voz en la distancia es uno de los alicientes para fugarse. A diferencia del personaje del profesor Manuel, en Paso a paso, de Irene Vasco, que cumple su misión de adulto y de mediador al ayudar a Patricia a encontrarse a sí misma luego del secuestro de su padre, la profesora Elvira, en cambio, deberá quedarse sola luchando (casi literalmente contra el mundo) en una situación de anomia social, en la que la guerra es el centro de la acción cotidiana en el pueblo donde trabaja. Ella misma no está exenta de ser afectada directamente por las causas del conflicto armado. Un oficial del Ejército, que persigue a la guerrilla en la zona donde ella trabaja, la obliga a someterse a varios interrogatorios. Allí la pregunta central es “¿Dónde está la guerrilla? Usted y sus estudiantes lo saben" (p. 40). De manera inteligente, equilibrada, atenta a los riesgos de una respuesta que la pueda comprometer a ella y a sus estudiantes, responde:

- Teniente, dígame una cosa: ¿si usted viviera en un pueblo como este, contestaría esa pregunta?

La mirada fija y arrogante del teniente se desinfló. (p. 40).

Es la actitud crítica ante las "mentiras revolucionarias" de la guerrilla lo que le permite al joven héroe de Era como mi sombra pasar de un estado de "identidad en construcción" (en el capítulo 4, por ejemplo) a uno de "identidad autoconsciente" en el capítulo 13. Una identidad distanciada de la influencia de los adultos que lo han manipulado en el grupo armado, y que asume como señal de libertad y esperanza.

Intento salir de esta pesadilla. Cierro los ojos y pienso con fuerza en mi sueño. "Así — decía mi tío — se atraen con la mente los buenos deseos y se espantan las angustias." 
Yo, dueño de un pedazo de tierra en la montaña, bonito, con agua por todo lado, para no andar de tumbo en tumbo como le tocó a él: andariego, recoja un día café, otro algodón. (Lozano, 2015, p. 85).

La experta en historia de la literatura infantil colombiana, Lillyam González (2013), en una investigación dedicada al realismo en la literatura juvenil latinoamericana concluye con razón al respecto que "en estos libros se presenta un futuro esperanzador, en el que se asume el pasado y se hacen proyecciones a futuro. No se quedan en el regodeo de una historia realista desarrollada en un contexto de represión; superan la denuncia y se insta a continuar" (p. 16).

Dos aspectos finales que nos interesa discutir antes de cerrar este ensayo tienen que ver con el manejo de las escenas de violencia en Era como mi sombra, y con el motivo católicoreligioso, que aunque parezca secundario en el marco amplio de obra, sí revela mucho sobre el contexto ideológico de la autora.

La guerra - con su devastadora violencia física, destructiva, homicida, profundamente irracional e inhumana- es permanente como tema en la literatura occidental, desde la Iliada (siglo VIII a. C.). Su representación en los libros para niños y jóvenes no deja de ser problemática, pues este es uno de los temas "tabú" o "perturbadores", como los ha llamado un experto ${ }^{99}$. La herencia de este tabú, que es del siglo XIX, supone que la literatura tiene un fin edificante y que existen temas permitidos para los niños y otros que son prohibidos. Cierta idea del niño como sujeto incompetente para interpretar la violencia en los libros o fácilmente impresionable (¡en la época de los videojuegos violentos como Postal o Call of Duty!) ha caracterizado a los mediadores (padres, bibliotecarios, maestros) que tienen este punto de vista ${ }^{100}$. Sin embargo, el tratamiento de "imágenes sensibles" no deja de ser un problema tanto para el autor de estos libros, como para el editor que convierte un manuscrito en libro y la editorial que los hace circular socialmente.

\footnotetext{
99 "La perturbación está fuertemente vinculada con esa sombra, que en términos junguianos se refiere a muchos aspectos disociados de la personalidad consciente, como la envidia, el deseo de muerte, el odio, la mentira, la traición, la guerra, la violencia gratuita, el desprecio, la burla, el rencor, el miedo, el ansia de dominio, el poder, la avaricia, los celos... y un largo etcétera de aspectos que muchas veces se encuentran reprimidos". (Hanán Díaz, 2015, p. 77). Recuperado de: http://bit.ly/1PuOcPM

100 Con humor, la argentina Mónica Cerezales ha propuesto una alternativa: "Hablar de eso, entendido como el eso-tabú, tal vez evitaría que muchos niños y niñas sigan mirando y sintiendo lo diferente con recelo, temor, sin poder asignarles algún nombre que los signifique, en un aporte a la construcción de nuevas representaciones y al otorgamiento de otros sentidos. Hablemos". (Cerezales, 2012, p. 112). Recuperado de: http://bit.ly/1KPTR42
} 
En Era como mi sombra, Pilar Lozano ha evitado al máximo mostrar homicidios, masacres, decapitaciones o torturas, macabramente habituales dentro de los grupos armados ilegales. En Crecimos en la guerra (2014), su libro de crónicas, en cambio, las voces narradoras (muchachos exguerrilleros o paramilitares, desvinculados del conflicto armado y en proceso de resocialización) sí describen sin ningún tipo de censura o tapujo los hechos más crueles ${ }^{101}$.

\section{Esquema 17. Análisis escenas de violencia en Era como mi sombra}

\begin{tabular}{|l|c|c|}
\hline & Descripción directa & Elipsis \\
\hline $\begin{array}{l}\text { Capitulo 1 } \\
\text { Asesinato de Martínez }\end{array}$ & $\mathrm{X}$ & \\
\hline $\begin{array}{l}\text { Capitulo 4 } \\
\text { Asesinato del tío Pedro }\end{array}$ & $\mathrm{X}$ & \\
\hline $\begin{array}{l}\text { Capitulo 6 } \\
\text { Toma del pueblo por la guerrilla }\end{array}$ & $\mathrm{X}$ & $\mathrm{X}$ \\
\hline $\begin{array}{l}\text { Capitulo 7 } \\
\text { Quema de papelería electoral }\end{array}$ & $\mathrm{X}$ & \\
\hline $\begin{array}{l}\text { Capitulo 9 } \\
\text { Combate con el ejército. Muerte } \\
\text { de un soldado }\end{array}$ & & $\mathrm{X}$ \\
\hline $\begin{array}{l}\text { Capitulo 9 } \\
\text { Asesinato de un "informante" del } \\
\text { Ejército }\end{array}$ & & $\mathrm{X}$ \\
\hline $\begin{array}{l}\text { Capitulo 10 } \\
\text { "Paras" queman el pueblo }\end{array}$ & & $\mathrm{X}$ \\
\hline $\begin{array}{l}\text { Capitulo 11 } \\
\text { Asesinato de Matilde, la niña } \\
\text { guerrillera }\end{array}$ & & $\mathrm{X}$ \\
\hline $\begin{array}{l}\text { Capitulo 11 } \\
\text { Roberto, otro niño guerrillero, } \\
\text { muere en emboscada }\end{array}$ & & $\mathrm{X}$ \\
\hline $\begin{array}{l}\text { Capitulo 12 } \\
\text { Consejo de guerra y fusilamiento } \\
\text { de Julián }\end{array}$ & & \\
\hline
\end{tabular}

Nota: Elaboración propia.

Como lo vemos en el Esquema 17 en la novela solo cuatro escenas de violencia son presentadas de forma directa, es decir, detallando los crímenes, haciendo uso de del narrador

${ }^{101}$ Varios de estos relatos se han citado en la sección de Contexto histórico. 
directo libre ${ }^{102}$. Las otras seis escenas se presentan mediante el recurso de la elipsis ${ }^{103}$, esto es, de modo indirecto, elusivo, haciendo uso del narrador indirecto libre ${ }^{104}$. Las directas ocupan la primera parte de la novela; las elípticas, la segunda parte. Con ello Lozano genera tensión emocional en los primeros capítulos (atrapa al lector) y luego ya considera que el lector implícito ${ }^{105}$, en la segunda parte, puede agregar la información que falta en el texto ${ }^{106}$. En las escenas de violencia mediante descripción directa, la autora es puntualísima en el lenguaje (hay un notorio nivel de economía narrativa) y evita la morbosidad, los primeros planos de sangre o la exaltación del victimario:

Empezaron los disparos al aire. Todo mundo salió corriendo; mi tío se quedó ahí, en la alegadera. Me escondí detrás de un poste. Mi mamá se acercó más y alcancé a escucharla suplicar con voz lastimera:

—No le hagan nada, él tiene familia por quien responder...

Fue como darles veneno. Empezaron a disparar como enloquecidos. Y yo, mirando todo... quieto, sin poder hacer nada.

El pulso, de lo mismo fuerte, me formó un vacío en el pecho. Sentí que me inyectaban a un mismo tiempo ira y dolor en la sangre.

Pesaba más el dolor, pienso ahora: sentí como si me destrozaran el corazón a mordiscos cuando lo vi caer, doblado. (Lozano, 2015, p. 25).

En las escenas narradas mediante elipsis, en menos de 100 palabras el narrador indirecto libre cuenta lo que sucedió:

Pero mucho más verraco ver caer a un desarmado. Una vez nos ordenaron a

\footnotetext{
${ }^{102}$ Ver definición en la p. 90.

${ }^{103}$ La elipsis "consiste en la supresión de una imagen, pero que el contexto hace que se comprenda. En realidad, la omisión se produce por economía textual, ya que no es necesario expresar lo que resulta sobrentendido" (Marín, 2009, p. 77).

${ }^{104}$ En el discurso indirecto libre "el narrador se coloca en el lugar del otro, ve como vería el otro, habla como si fuera el otro”. (Marín, 2009, p. 74).

${ }^{105}$ La definición de "lector implícito" se halla en la página 34.

${ }^{106}$ Como bien lo ha señalado Tabernero (2003), la focalización interna (narrador en primera persona) en los relatos que tratan sobre conflictos bélicos enriquece visiblemente el relato, pues se potencia "no tanto la exposición de las acciones, de los hechos, sino la perspectiva desde la que se viven los mismos. No importa tanto qué ha ocurrido como los sentimientos que la acción ha provocado en quien ha sufrido sus consecuencias". (p. 664).
} 
Julián, a Efraín, a Julio y a mí ajusticiar a un campesino. Alguien lo acusó de ser sapo, de irle con cuentos al ejército. Cuando nos vio se sentó entre unas matas llenas de flores. Se achicó, suplicaba con sus ojos desorbitados. Movía los labios sin lograr pronunciar nada. Se le murieron primero las palabras. Me sentí infeliz, el más cobarde de los cobardes. Quedé confuso, aturdido. Mantuve despierto hasta muy tarde. (Lozano, 2015, p. 61).

Finalmente, quiero referirme al motivo católico-religioso en Era como mi sombra. Diversos autores (Gutiérrez Girardot, 2005; Abel, 1985; Gómez García, 2006; Jaramillo Vélez, 2014; Zubiría, 2014) han señalado que el catolicismo hispano-contrarreformista es una de las causantes de la violencia política colombiana. Y no dejan de tener razón si se toma en cuenta que la religión fue uno de los vehículos ideológicos que, por ejemplo, utilizó la dictadura de Laureano Gómez (1950-1953) para justificar su persecución a toda opinión diferente a la propia, que era acusada de "atea", "comunista". Varios sacerdotes -entre ellos el oscuramente recordado monseñor Builes en Santa Rosa de Osos- desde el púlpito instaron abiertamente a los feligreses a matar a los opositores, en una cruzada que según Guzmán Campos et al. (1962; 1988) dejó cerca de 250 mil campesinos asesinados entre 1948 y 1960.

En Era como mi sombra -según el Esquema 18- la religión católica aparece con una connotación definidamente positiva, que merece ser analizada con cuidado. 
Esquema 18. El motivo religioso-católico en Era como mi sombra

\begin{tabular}{|c|l|l|}
\hline Capitulo & \multicolumn{1}{|c|}{ Escena } & \multicolumn{1}{|c|}{ Connotación } \\
\hline 1 & $\begin{array}{l}\text { El narrador hace un pacto de lealtad con su amigo } \\
\text { Julián, y lo sella como promesa a la Virgen. (p. 4). }\end{array}$ & $\begin{array}{l}\text { Positiva. Cumplimiento } \\
\text { de un acuerdo. }\end{array}$ \\
\hline 6 & $\begin{array}{l}\text { El niño prepara su viaje para ingresar a la guerrilla. } \\
\text { La abuela le da la bendición, consejos, y le pide } \\
\text { encomendarse a la Virgen: “iElla me ha hecho } \\
\text { tantos milagros....”. (p. 35). }\end{array}$ & $\begin{array}{l}\text { Positiva. Protección en } \\
\text { caso de riesgo de morir. }\end{array}$ \\
\hline 7 & $\begin{array}{l}\text { La madre le da al niño que se va a la guerra una } \\
\text { oración (religiosa) y una foto de ella. (p. 43). }\end{array}$ & $\begin{array}{l}\text { Positiva. Valor del } \\
\text { recuerdo, asociado al } \\
\text { culto mariano. }\end{array}$ \\
\hline 10 & $\begin{array}{l}\text { El niño guerrillero reza antes de entrar al combate. } \\
\text { (p. 64). }\end{array}$ & $\begin{array}{l}\text { Positiva. Esperanza ante } \\
\text { la posibilidad de morir. }\end{array}$ \\
\hline 10 & $\begin{array}{l}\text { Julián carga un escapulario en el tobillo que “con } \\
\text { tanto sudor, con tanta pasadera de ríos y quebradas, } \\
\text { se fue deshaciendo. Al final, parecía una hilacha”. } \\
\text { (p. 64). }\end{array}$ & $\begin{array}{l}\text { Positiva. Símbolo de } \\
\text { protección en medio del } \\
\text { peligro. }\end{array}$ \\
\hline 13 & $\begin{array}{l}\text { El joven exguerrillero -luego de la deserción- } \\
\text { carga en un bolso una hojita con el Salmo 91, } \\
\text { como lo hacía su tío Pedro. (p. 86). }\end{array}$ & $\begin{array}{l}\text { Positiva. La muerte no } \\
\text { vencerá. Esperanza ante } \\
\text { el futuro. }\end{array}$ \\
\hline
\end{tabular}

Nota: Elaboración propia.

Se dirá que es obvio que los personajes de la novela invoquen motivos religiosos pues en las sociedades rurales el catolicismo garantiza la verticalidad del "mundo de la hacienda" (Gutiérrez Girardot, 2005, p. 91) y es un factor ideológico que identifica y unifica a la sociedad tradicional. Los marxistas dirán que la religión es "el opio del pueblo" y que tiene carácter enajenante. Pero no deja de ser paradójico que en una guerrilla revolucionaria, en la que milita el niño héroe de la historia, donde sus comandantes se declaran ateos, él rece capítulo 10- una oración antes de entrar al combate (seguramente contra el Ejército, la Policía o los paramilitares). Una oración muy popular que se enseña todavía en los hogares campesinos, en la escuela (incluso las laicas) y en los ritos como la primera comunión o la confirmación.

Yo, Jesús, tengo mil dificultades; ayúdame. De los enemigos del alma, sálvame.

De mis dudas y penas, confórtame. Cuando me desprecien, anímame. De las tentaciones, defiéndeme. En las horas difíciles, consuélame. Con tu corazón 
paternal, ámame. Con tu inmenso poder, protégeme, y en tus brazos, al expirar, recíbeme. (Lozano, 2015, p. 64).

En el pueblo - caserío, como dice el niño narrador- donde suceden los acontecimiento de Era como mi sombra, había una iglesia donde "de cuando en cuando iba un cura" (p. 6), lo que nos invita a pensar que debía ser muy pocas veces, probablemente en semana santa o en las fiestas navideñas. Julián, que es más fervoroso que su amigo, demuestra su respeto ante la autoridad religiosa:

Las pocas veces que iba el cura al caserío, él era el primero en llegar a la iglesia. Se ofrecía para barrer, limpiar el polvo y las telarañas acumuladas entre visita y visita" (p. 64)

No nos interesa aquí entrar en una polémica de si la influencia religiosa (en este caso la católica) es buena o mala para la gente. En el contexto ideológico de la novela de Pilar Lozano, el catolicismo cumple una función de esperanza en medio del agobio. A la familia humilde del niño guerrillero no le queda otra opción en medio de la pobreza material absoluta que atarse a símbolos religiosos católicos, vista la anomia social del lugar en que viven (falta de presencia del Estado, autoridades que cambian según las reglas de la guerra, cotidianidad basada en la sobrevivencia física).

Esta valoración del motivo religioso en un entorno de guerra sin cuartel - descrita con un cuidado distanciado por Pilar Lozano en Era como mi sombra- es un aviso para la Iglesia católica y sus comunidades de base. Así haya una notoria declinación de la fidelidad religiosa en las grandes ciudades, en los pueblos de Colombia (más de mil municipios tienen esta condición) la doctrina católica sigue teniendo un peso en el mundo rural que no se puede desconocer. La Iglesia -sus representantes tanto sacerdotes como seglares- pueden aprovechar esta ventaja como oportunidad para ayudar en la reconstrucción de comunidades escindidas, totalmente golpeadas por los efectos del conflicto armado. Una Iglesia del lado de los más pobres -según el ideal del padre Camilo Torres Restrepo- que garantice la convivencia, la reconstrucción de tejido social y ayude a construir esperanza en medio del desastre. 


\section{COLOFÓN}

Era como mi sombra, de Pilar Lozano, es una novela de corte realista que retrata uno de los hechos más vergonzosos del conflicto armado en Colombia: el reclutamiento de niños y jóvenes por parte de los grupos armados ilegales (guerrillas y paramilitares). Lo hace con una prosa directa, sucinta, poderosamente poética y que acude sin complejos a tocar las emociones del lector. Si bien sus principales destinatarios son los jóvenes, ello no excluye que otros lectores sensibles al drama del sufrimiento de los niños en las guerra, encuentren argumentos para detenerse y pensar de qué modo pasamos la página del horror e invitamos a estos niños a ser parte del proceso de inclusión que se inicia con el Acuerdo del paz y el posconflicto.

El periodista Álvaro Sierra $\left(2015\right.$, p. 19) ${ }^{107}$ advierte con razón que el país urbano tiene una deuda con el país rural: la gente en las grandes ciudades ha visto la guerra por televisión y no la ha sufrido en carne propia, como sí le ha tocado a la gente del campo, a los niños que retrata Pilar Lozano en Era como mi sombra ${ }^{108}$. Lozano, que ha recorrido centenares de municipios pobres del país mostrando como periodista lo bello y lo triste, ahora en esta novela asume el papel de intelectual, de ciudadana crítica. Hace un reclamo -literariamente logradísimo en nuestra opinión- que suma a la ternura, la solidaridad; a la emoción, la inteligencia $^{109}$. El inolvidable protagonista, el niño guerrillero, que al final ya como joven recupera lo más preciado para un ser humano, la libertad y, a su vez su identidad, es su legado como escritora de libros para niños y jóvenes sobre el valor de la justicia y el compromiso que tenemos los colombianos de reconstruir un país luego de la tragedia.

\footnotetext{
${ }^{107}$ Recuperado de: http://bit.ly/10814cM

${ }^{108}$ Sierra, en consecuencia, propone que ese país urbano debería superar los argumentos guerreristas y votar en el plebiscito (o el mecanismo constitucional que se decida) a favor de la paz, del cese al fuego y del cumplimiento de los acuerdos pactados en La Habana.

${ }^{109}$ Bien lo dice Consuelo Triviño en una reseña en su blog: "El relato no juzga a los ejecutores de la barbarie, ni siquiera los nombra". Recuperado de: http://bit.ly/1Qej309
} 


\section{Capítulo 4}

\section{Propuesta de Secuencia didáctica (Sd) Con BASE EN ERA COMO MI SOMBRA}




\section{LA SECUENCIA DIDÁCTICA (SD) COMO DISPOSITIVO PEDAGÓGICO PARA LA ENSEÑANZA DE}

\section{LA LITERATURA}

La secuencia didáctica (SD) es una estrategia didáctica, relativamente reciente, que basa su potencia en el diseño curricular a mediano plazo y en la producción planeada de un texto oral o escrito (Dolz, 2004). La secuencia didáctica se halla a medio camino entre las actividades (ocasionales o permanentes) y el proyecto de aula. Es decir, constituye una actividad de complejidad intermedia.

Surgió como alternativa pedagógica de enseñanza en respuesta a la inefectividad de actividades aisladas, mecánicas, muchas tomadas de libros de texto, para enseñar a leer y escribir. En cierto modo la SD responde a una necesidad en la enseñanza de la lengua que surgió en vista de los deficientes resultados obtenidos por los estudiantes de grados finales de educación primaria y secundaria en pruebas de evaluación masiva nacionales e internacionales (Saber, Pisa, Pirls).

De modo similar, los análisis de las prácticas docentes en las aulas demuestran que los niños y jóvenes de educación primaria y secundaria en los países latinoamericanos presentan severas limitaciones en sus competencias para responder a las exigencias que la cultura escrita impone a comienzos del siglo XXI (Peña Borrero, 2002, p. viii).

El origen del concepto secuencia didáctica es francófono y fue desarrollado por el profesor Joaquim Dolz y su equipo de investigación de la Universidad de Ginebra a finales de los años 90. Para Dolz et al. (2013), la secuencia didáctica es:

...un dispositivo didáctico para la enseñanza de la lengua y la literatura interesado, por una parte, en centrarse en una situación de comunicación y las convenciones de un género particular $y$, por otra parte, por organizarse y articular diferentes actividades escolares con el fin de superar las dificultades de los alumnos. Esta herramienta propone un modo de organización de las actividades que reúne diversos contenidos alrededor de los principales problemas de escritura cuando se elabora una producción inicial. (p. 7-8).

Las secuencias didácticas tuvieron recepción en el ámbito en lengua española a través de Ana Camps (Universidad de Barcelona), quien coordinó la publicación de un tomo recopilatorio de ellas, Secuencias didácticas para escribir (2003), publicado por la editorial catalana Graó, 
y luego otro en compañía del profesor Felipe Zayas: Secuencias didácticas para aprender gramática (2006). Para Camps lo que caracteriza a una SD es que:

...está constituida por un conjunto de tareas diversas, pero todas ellas relacionadas con un objetivo global que les dará sentido. Lo que otorga unidad al conjunto no es únicamente el tema, sino la actividad global implicada, la finalidad con que se lleva a cabo. (Camps, 2006, p. 34).

Lo que se manifiesta en esta definición es la clara percepción de que la educación lectora y escritural ha estado marcada por la enseñanza de saberes aislados de su uso, esto es, de su potencial como competencia. En clase de gramática, por ejemplo, se aprenden los conectores, pero con ello no se indica cuál será la efectividad de este saber en el uso de la lengua escrita. Se memoriza una información, pero no resulta un saber (un contenido) significativo, que permita consolidar competencias comunicativas. Como dice Camps, son actividades aisladas en las que se pierde el "objetivo global que les dará sentido".

En México, el profesor Ángel Díaz Barriga (Unam) ha sido más enfático y ha reclamado que las secuencias didácticas se deben centrar no en la enseñanza sino en el aprendizaje:

Las secuencias didácticas constituyen una posibilidad de trabajar hacia enfoques centrados en el aprendizaje. Permiten el docente pensar desde la situación de los alumnos, lo obligan a analizar tanto las experiencias previas de los estudiantes, como asumir el reto de articular elementos conceptuales con las textos de la realidad, lo que los constructivistas prefieren denominar auténtico (Díaz Barriga, 2013, p. 31)

Este giro introduce un elemento valioso de cambio porque ubica a las SD en un horizonte pedagógico basado en la innovación educativa, en la escuela montessoriana y en el aprendizaje significativo:

La secuencia didáctica es el resultado de establecer una serie de actividades de aprendizaje que tienen un orden interno entre sí. Con ello (...) demanda que el estudiante realice cosas, no ejercicios rutinarios o monótonos, sino acciones que vinculen sus conocimientos y experiencias previas con alguna interrogante que provenga de lo real y con información sobre un objeto de conocimiento. (p. 19). 
En Colombia han sido los profesores Gloria Rincón (Universidad del Valle) y Mauricio Pérez Abril (Universidad Javeriana), quienes introdujeron el concepto de secuencia didáctica en la legislación curricular a través de la asesoría que hicieron a la Secretaría de Educación de Bogotá con las cartillas: Referentes para la didáctica del lenguaje (Pérez Abril et al., $2010)^{110}$. En su opinión,

una secuencia didáctica concreta unos propósitos específicos de enseñanza y aprendizaje, planeados por el docente, y vincula unos saberes y saberes hacer particulares, en el marco de una situación discursiva que le otorga sentido. En una secuencia didáctica, que está constituida por una sucesión de acciones e interacciones, debe ser posible evidenciar el criterio de asignación de complejidad entre las actividades a medida que transcurre su desarrollo. Otro elemento clave de una secuencia es que está ligada a una producción discursiva específica: un texto, una intervención oral pública, una disertación (p. 59).

El aporte innovador que Rincón y Pérez han hecho consiste en ubicar las modalidades didácticas dentro de un proceso que implica el aumento de la complejidad pedagógica, con el fin de alcanzar logros más significativos en el aprendizaje de los estudiantes. Esto lo han basado en Litwin (1997), a quien se debe el concepto “configuraciones didácticas”, las cuales se pueden entender como "la manera particular que despliega el docente para favorecer los procesos de construcción del conocimiento" (p. 97).

En consecuencia, desde mi perspectiva, estas configuraciones didácticas se clasificarían, entonces, en cuatro modalidades (ver Esquema 19).

\footnotetext{
${ }^{110}$ Se pueden consultar en línea. Recuperado de: http://bit.ly/1QDBz8s
} 


\section{Esquema 19. Clasificación de las modalidades didácticas en el aula}

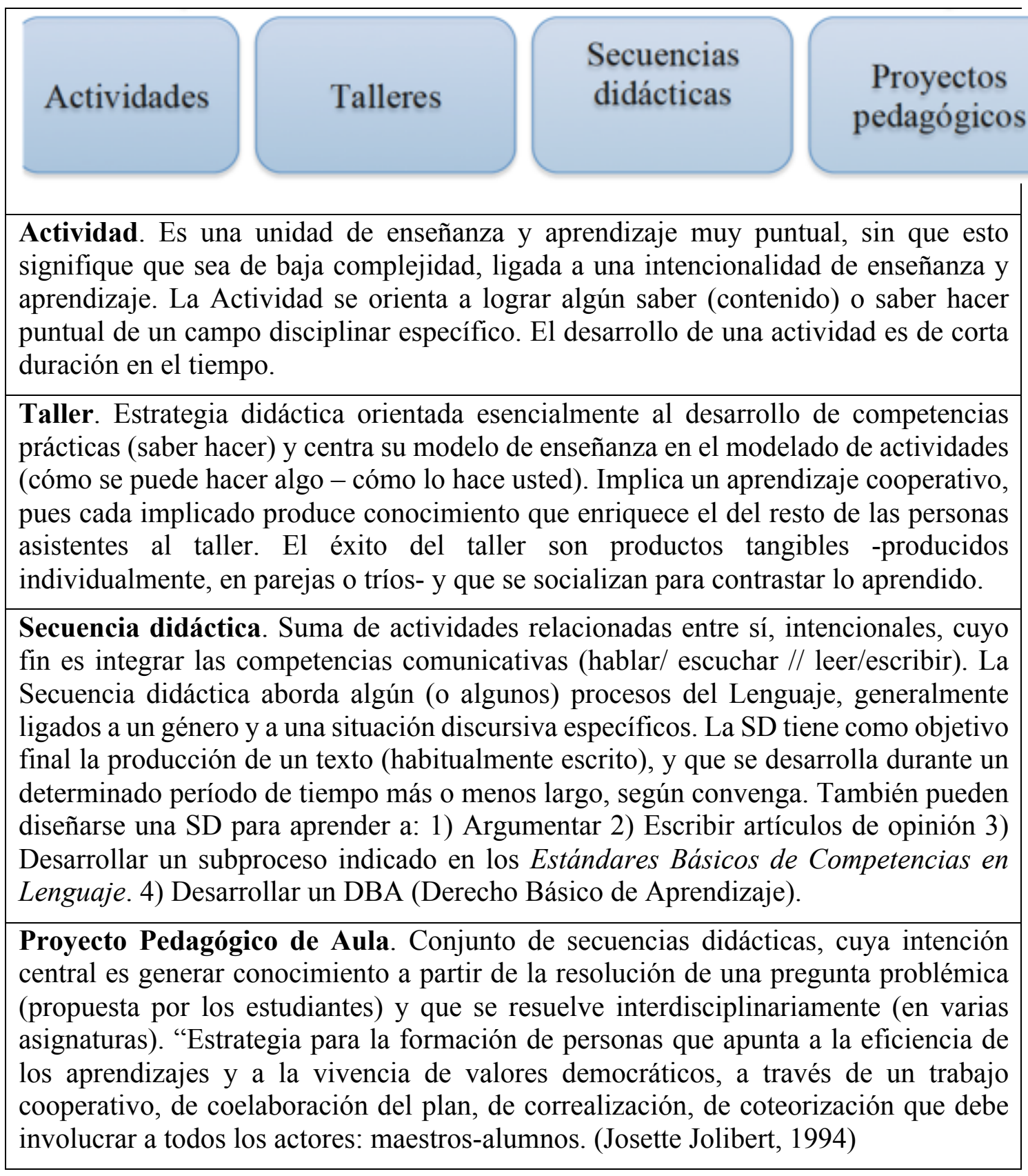

Nota. Esquema realizado con información propia y adaptación parcial del esquema sugerido por Pérez Abril, M. et al. (2013). Escribir la propia práctica: Una propuesta metodológica para planear, analizar, sistematizar y publicar el trabajo didáctico que se realiza en las aulas. Bogotá: Pontificia Universidad Javeriana.

Según Pérez y Rincón (2009) ${ }^{111}$ las cuatro condiciones generales que debe seguir una secuencia didáctica son:

${ }^{111}$ Recuperado de: http://bit.ly/1Lho4U7 
1) Definir claramente los propósitos, en relación con el proceso (o procesos) del lenguaje, los saberes y saber-hacer que serán su objeto de trabajo, y las producciones discursivas que se esperan.

2) Explicitar el sistema de postulados teóricos, en relación con el lenguaje y la enseñanza, que soportan el trabajo didáctico.

3) El diseño de un sistema de acciones con sus correspondientes propósitos de aprendizaje y enseñanza y ligados a una producción discursiva particular, en los cuales sea posible reconocer el criterio de asignación de complejidad en el transcurrir de la Secuencia.

4) Contar con un mecanismo de seguimiento y evaluación tanto del desarrollo de la Secuencia, como de los aprendizajes alcanzados y las producciones discursivas.

Toda secuencia didáctica supone una forma de organización por parte del docente para que sea efectiva en el aula. Pérez y Rincón (2009, p. 6), siguiendo la propuesta organizativa de Camps (2006, p. 35) proponen que debe llevar tres partes.

a. La fase de preparación. Es el momento en que se formula el proyecto y se explicitan los nuevos conocimientos que se han de adquirir, formulados como criterios que guiarán la producción. Es también la fase de la primera elaboración de los conocimientos necesarios para llevar a cabo la tarea: contenidos, situación discursiva, tipo de texto, etc. Tienen lugar actividades muy variadas como lecturas, búsqueda de información, ejercicios, etc.

b. La fase de producción. Es aquella en que los alumnos escriben el texto. Puede tener características muy diferentes, según el tipo de secuencia, de texto, de objetivos, etc. Se puede llevar a término de forma individual, colectiva o en grupo; puede ser de larga o de corta duración, etc. Durante la tarea, los escritores pueden utilizar el material elaborado durante la fase de preparación. La interacción oral con los compañeros, y sobre todo con el maestro, es el instrumento imprescindible para aprender a seguir procesos adecuados de producción escrita.

c. La fase evaluación. Debe basarse en el logro de los objetivos planteados, que son los criterios que habrán guiado la producción. Es por lo tanto una evaluación formativa. 
En mi opinión las ocho razones por las cuales las Secuencias didácticas aportan un plus al trabajo con la literatura en el aula son:

1) Materializan la idea de un plan curricular coherente que se basa en el desarrollo de competencias, conocimientos y habilidades por ciclos de grado.

2) Integran varias habilidades (leer, escribir, oralidad) en una sola estrategia didáctica sistémica.

3) Empoderan al docente para construir currículo.

4) Fomentan el trabajo cooperativo entre docentes.

5) Involucran de modo activo a los estudiantes en el aprendizaje.

6) Establecen como fase final un producto escrito trabajado mediante varios borradores y versiones.

7) Generan una posibilidad de evaluación basada en niveles de desempeño del desarrollo de la competencia comunicativa de los estudiantes.

8) Constituyen un reto en lo consolidación de un docente que reflexiona e investiga sobre su práctica pedagógica.

Nuestro interés en desarrollar una secuencia didáctica (SD) alrededor del conflicto armado en la narrativa juvenil colombiana parte de tres consideraciones:

a) La SD le permitirá al docente tener una valoración proyectiva de la literatura, esto es, que la literatura no es un objeto de conocimiento dado (como lo transmiten algunos libros de textos y las enciclopedias de historia literaria), sino en construcción. Y que esa construcción que denominamos texto literario se da, precisamente, por el aporte que hacen los lectores (destinatarios de esos textos) a partir de la interacción y el diálogo con las obras. Los estudiantes son los protagonistas del aprendizaje y los que le darán significado a esta obra.

b) La SD puede ayudar a que los estudiantes consulten información de manera independiente (por su propio interés) y aporten nuevo conocimiento. Si les resultan relevantes las actividades de la secuencia didáctica, se involucrarán de modo activo (recordemos lo que dijo antes al respecto el profesor Díaz Barriga) trayendo a clase más información para el debate con sus compañeros. De cualquier modo, el tema del conflicto armado y su representación en las novelas que leerán (Paso a paso, de Irene Vasco, y Era como mi sombra, de Pilar Lozano) 
ya no será un asunto ajeno (incluso inexistente), sino un problema real que como jóvenes deberán reflexionar con atención si quieren ser ciudadanos participantes con voz activa en la sociedad.

c) La SD puede ayudar a que los lectores débiles (Manresa, 2009, p. 34) encuentren un apoyo y estímulo al acto de acercarse a los libros de literatura. Podría generar en ellos actitudes de lectura más asertivas, menos basadas en la respuesta autodefensiva. Estos jóvenes pueden encontrar que la literatura "sirve para algo", al menos, para entender aspectos de la realidad colombiana que no conocían antes. Quizás podría pasar a preguntarle al docente por otros libros para leer.

La SD que desarrollaremos alrededor del libro Era como mi sombra se titula "Los niños de la guerra en Colombia".

Toma en consideración 2 subprocesos de los Estándares Básicos de Competencias en Lenguaje:

\begin{tabular}{|l|l|}
\hline Grado $\mathbf{7}^{\mathbf{0}}$ & $\mathbf{G r a d o ~}^{\mathbf{0}}$ \\
\hline $\begin{array}{l}\text { Formulo hipótesis de comprensión acerca } \\
\text { de las obras literarias que leo teniendo en } \\
\text { cuenta género, temática, época y región. }\end{array}$ & $\begin{array}{l}\text { Leo con sentido crítico obras literarias de } \\
\text { autores latinoamericanos. }\end{array}$ \\
\hline
\end{tabular}

Paralelamente hace énfasis en dos Derechos Básicos de Aprendizaje (DBA) (Men, 2015) que se acomodan a los objetivos pedagógico-literarios de la SD:

\begin{tabular}{|l|l|}
\hline Grado $\mathbf{7}^{\mathbf{0}}$ & Grado 8$^{\mathbf{0}}$ \\
\hline $\begin{array}{l}\text { Identifica el contexto social, histórico, } \\
\text { político y cultural de las obras, para } \\
\text { ampliar el análisis y la evaluación del } \\
\text { texto. }\end{array}$ & $\begin{array}{l}\text { Aprecia el legado literario colombiano y } \\
\text { latinoamericano, mediante la lectura de } \\
\text { textos de ficción y no ficción, poesía, } \\
\text { ensayos y obras periodísticas. }\end{array}$ \\
\hline
\end{tabular}

La SD "Los niños de la guerra en Colombia" consta de 13 sesiones organizadas en 20 horas/clase sugeridas. 
MAPa de las 13 SeSiones QUe CoMponen la Secuencia didáctica

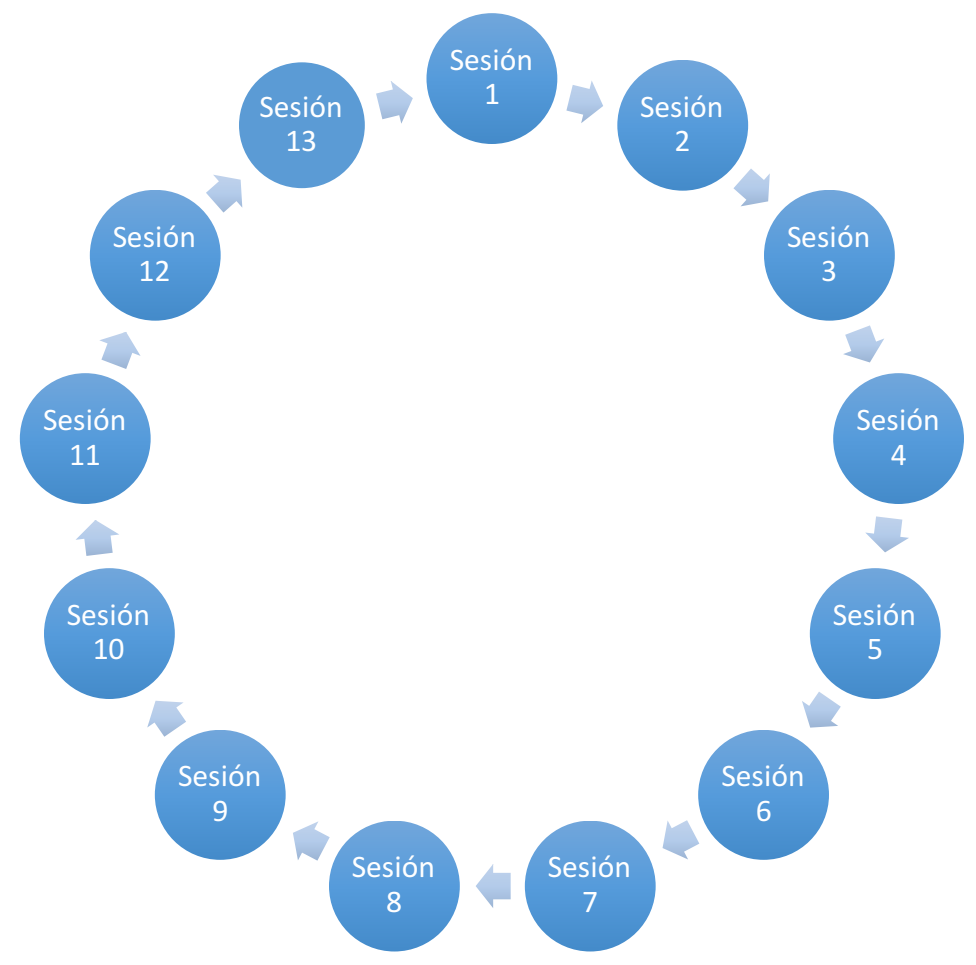

\begin{tabular}{|c|c|c|}
\hline Sesión & $\begin{array}{l}\text { No. horas } \\
\text { sugeridas }\end{array}$ & Título de la sesión \\
\hline 1 & 2 & Lectores y texto se acercan \\
\hline 2 & 1 & Los Paratextos \\
\hline 3 & 1 & La Autora ( $1^{\mathrm{a}}$ parte $)$ \\
\hline 4 & 1 & La Autora ( $2^{\mathrm{a}}$ parte $)$ \\
\hline 5 & 2 & Consulta de información extratextual \\
\hline 6 & 1 & Red Textual y Lecturas paralelas \\
\hline 7 & 2 & Juego de roles y lectura del capítulo 1 de Era como mi sombra \\
\hline 8 & 1 & Primera lectura de la novela. Lectura cuasiespontánea \\
\hline 9 & 1 & Ficha de personaje y centración en aspectos locales del texto \\
\hline 10 & 2 & Verificación de dominio de las habilidades de comprensión textual \\
\hline 11 & 2 & Desarrollo de la lectura crítica. Escritura de un comentario ( $1^{\mathrm{a}}$ parte) \\
\hline 12 & 2 & Desarrollo de la lectura crítica. Escritura de un comentario ( $2^{a}$ parte) \\
\hline 13 & 3 & Construcción de competencias ciudadanas: Empatia \\
\hline
\end{tabular}

A continuación aparece detallada el desarrollo de la secuencia didáctica "Los niños de la guerra en la literatura infantil”". 


\begin{tabular}{|l|l|l|}
\hline SESIÓN 1 & $\begin{array}{l}2 \\
\text { SUGERIDAS }\end{array}$ & LECTORES Y TEXTO SE ACERCAN \\
\hline
\end{tabular}

Profesor, si hay la posibilidad tecnológica en el aula (televisor, parlantes y reproductor de video), inicie la sesión con la presentación de algún video corto en que se muestre la situación de los niños reclutados por los grupos armados ilegales en Colombia ${ }^{112}$.

Si no hay la posibilidad de presentar el video, entregue una fotocopia del texto Reclutamiento de menores que se puede descargar en: http://bit.ly/1QkSaOg

Antes de ver el video o leer el texto, entregue a los estudiantes una hoja con las siguientes preguntas para discutirlas en clase.

1) ¿Cuál es el tema del video (o del texto)? ¿De qué trata? ¿Qué palabras o conceptosclave asocias con lo visto o leído?

2) ¿Qué sabías sobre el tema?

3) ¿Qué te impactó (del texto o del video)? ¿Por qué?

4) ¿Qué preguntas te suscita el texto?

5) ¿Sobre qué tema expuesto en el video (o texto) te interesaría investigar?

6) ¿Si el niño protagonista del video (o los niños guerrilleros o paramilitares de lo que se habla en el texto) entrara al salón en este momento, qué harías, qué le dirías?

\footnotetext{
${ }^{112}$ Puede consultar los siguientes videos en You Tube: http://bit.ly/1LtsNm8; http://bit.ly/1Og8FUn
} 


\begin{tabular}{|l|l|l|}
\hline SESIÓN 2 & $\begin{array}{l}1 \\
\text { SUGERIDA }\end{array}$ & LOS PARATEXTOS \\
\hline
\end{tabular}

Docente, pídales a sus estudiantes ojear sus ejemplares de Era como mi sombra. Indíqueles que únicamente miren los paratextos ${ }^{113}$ (carátula, contracarátula y perfil biográfico) y que realicen estas actividades ${ }^{114}$.

1) Observen con atención la carátula y lean la contracarátula de Era como mi sombra. Anticipen qué temas tocará la novela.

\begin{tabular}{|l|l|}
\hline \multicolumn{2}{|l|}{ Este libro probablemente trata de... } \\
\hline Tema 1 & \\
\hline Tema 2 & \\
\hline Tema 3 & \\
\hline
\end{tabular}

2) Consulten sitios en internet que informen sobre el reclutamiento forzado de menores de edad por parte de los grupos armados en Colombia. Completen el esquema con los resultados de su búsqueda.

\begin{tabular}{|l|l|l|l|}
\hline Enlace & Nombre del sitio & $\begin{array}{l}\text { Confiabilidad } \\
\text { (Alta/Media/Baja) }\end{array}$ & $\begin{array}{l}\text { Qué dice de } \\
\text { importante }\end{array}$ \\
\hline & & & \\
\hline & & & \\
\hline
\end{tabular}

3) A partir de los indicios, ¿a qué genero de novela pertenecería Era como mi sombra? Marquen con una $\mathrm{X}$.

${ }^{113} \mathrm{Si}$ no conocen el concepto, preséntelo en clase. Los paratextos son los signos que "rodean al texto propiamente dicho" y nos aportan información de contexto sobre su contenido global. Es un espacio de comunicación en el que se mezclan tanto aspectos publicitarios como aspectos gráficos que regulan el texto y lo ubican en un marco discursivo particular.

${ }^{114}$ Estas actividades han sido tomadas de la Guía de aula que escribí para Ediciones SM. Cfs en: http://bit.ly/1LuVLSG 


\begin{tabular}{|c|c|c|}
\hline Aventuras & Realista & Misterio \\
\hline & & \\
\hline Romántica & Histórica & Ciencia ficción \\
\hline
\end{tabular}

4) Lean el perfil biográfico de Pilar Lozano (página 87), autora de Era como mi sombra. ¿Cómo el ser periodista que ha cubierto el conflicto armado en Colombia, le puede servir al momento de escribir esta novela?

5) Enumeren expectativas que tienen antes de leer la novela Era como mi sombra.

\begin{tabular}{|l|}
\hline \\
\hline 2
\end{tabular}




\begin{tabular}{|l|l|l|}
\hline SESIÓN 3 & $\begin{array}{l}\text { HORA } \\
\text { SUGERIDA }\end{array}$ & LA AUTORA (1'a PARTE) \\
\hline
\end{tabular}

En esta (y la siguiente) sesión los estudiantes se concentrarán en el conocimiento del autor, antes de entrar a la lectura de la novela ${ }^{115}$.

Docentes, pídales a sus estudiantes que averigüen en internet (y si tienen oportunidad en una biblioteca pública o escolar) información sobre Pilar Lozano, pues entre todos le escribirán más adelante (sesión 4) un correo electrónico.

FICHA BIOGRAFICA DE PILAR LOZANO

\begin{tabular}{|l|l|}
\hline Foto \\
\hline Nombre completo \\
\hline Fecha de nacimiento \\
\hline Nacionalidad \\
\hline Hijos \\
\hline Estudios y ocupación \\
\hline Obras notables \\
\hline Premios \\
\hline $\begin{array}{l}\text { Convicciones, gustos, datos } \\
\text { destacados y curiosos }\end{array}$ \\
\hline $\begin{array}{l}\text { Qué hace a este autor } \\
\text { destacado }\end{array}$ \\
\hline $\begin{array}{l}\text { Qué acourgina web del autor } \\
\text { marcaron su vida }\end{array}$ \\
\hline \begin{tabular}{l} 
Pági tiene) acontecimientos \\
\hline
\end{tabular}
\end{tabular}

\footnotetext{
${ }^{115}$ Esta actividad se basa en la propuesta de secuencia didáctica: "Escribir como lectores", que el área de Lengua Castellana ha organizado en el Liceo Cambridge de La Calera (Cundinamarca), bajo la dirección de la profesora Claudia Guerrero, y de la cual soy asesor desde 2015: http://bit.ly/1Lri2nz. También se ha incluido información de esta SD en las sesiones 11 y 12.
} 


\begin{tabular}{|l|l|l|}
\hline SESIÓN 4 & $\begin{array}{l}1 \\
\text { HUGA }\end{array}$ & LA AUTORA (2a PARTE) \\
\hline
\end{tabular}

Con lo que hayan encontrado en sus investigaciones sobre quién es Pilar Lozano y luego de haber hecho la ficha biográfica, ahora los estudiantes, bajo su dirección profesor, escribirán de manera colectiva un correo electrónico a la autora (pililili33@hotmail.com ). También puede ser un mensaje al perfil de ella en Facebook (http://on.fb.me/1PGnTWO). En este primer mensaje le contarán lo que han aprendido sobre su vida y realizarán dos o tres preguntas sobre su obra Era como mi sombra. Estas preguntas preguntan pueden girar alrededor de:

- ¿Por qué fue importante para usted, Pilar, escribir este libro?

- ¿Por qué eligió ese tema?

- ¿Qué quiere, Pilar, transmitir en este libro? 


\begin{tabular}{|l|l|l|}
\hline SESIÓN 5 & $\begin{array}{l}2 \\
\text { SUGERIDAS }\end{array}$ & CONSULTA DE INFORMACIÓN EXTRATEXTUAL \\
\hline
\end{tabular}

Docente, esta sesión busca que sus estudiantes antes de comenzar la lectura de Era como mi sombra adquieran información (saberes extratextuales) que les permitan -en la jerga de Umberto Eco y de los Lineamientos curriculares de lengua castellana (1998)- enriquecer su “enciclopedia" sobre el tema del Conflicto armado en Colombia.

Invítelos a preparar para la siguiente clase una exposición oral de 10 minutos usando herramientas TIC como PP (Power Point) o Prezzi.

Pídales organizarse en grupos de tres estudiantes. Al azar, indíqueles escoger uno de estos temas.

1) ¡Qué es el conflicto armado?

2) ¿Por qué se originó el conflicto armado?

3) Cuáles son los grupos enfrentados en el conflicto armado

4) ¿Qué estadísticas ha dejado el conflicto: heridos, muertos, desplazados, secuestrados, desaparecidos?

5) ¿De qué modo han sido afectados los niños durante el conflicto armado?

6) Qué es el posconflicto?

7) ¿Qué requisitos son necesarios para obtener la paz en Colombia?

También infórmeles que deberán hacer una Cronología (línea de tiempo) en la que expliquen los 10 hechos más relevantes relacionados con su tema.

En todas las consultas de información tendrán cuidado en el uso de la citación de fuentes.

Los archivos en pdf de las exposiciones deben ser subidos al sitio web: http://es.slideshare.net/?ss

Profesor, sugerimos que seleccione las presentaciones en las que usted observe mejor manejo de la información y en las que le interese motivar a los estudiantes a compartir los conocimientos hallados.

Elabore una rúbrica para que los grupos sean evaluados. Puede seguir este modelo. 


\begin{tabular}{|c|c|c|c|c|c|}
\hline $\begin{array}{c}\text { Nombre } \\
\text { y apellidos }\end{array}$ & $\begin{array}{l}\text { La presen- } \\
\text { taclón del } \\
\text { PPT es } \\
\text { buena }\end{array}$ & $\begin{array}{l}\text { La Informa- } \\
\text { clón reque- } \\
\text { rida está } \\
\text { blen es- } \\
\text { tructurada } \\
\text { y recoglda } \\
\text { en el PPT. }\end{array}$ & $\begin{array}{l}\text { La exposi- } \\
\text { clón oral } \\
\text { está prepa- } \\
\text { rada. Utillza } \\
\text { el vocabu- } \\
\text { larlo ade- } \\
\text { cuado. }\end{array}$ & $\begin{array}{l}\text { La postura } \\
\text { y el tono de } \\
\text { voz son co- } \\
\text { rrectos. }\end{array}$ & $\begin{array}{c}\text { Es capaz } \\
\text { de respon- } \\
\text { der a las } \\
\text { preguntas } \\
\text { que se } \\
\text { hacen con } \\
\text { coherencla. }\end{array}$ \\
\hline & & & & & \\
\hline & & & & & \\
\hline & & & & & \\
\hline & & & & & \\
\hline
\end{tabular}




\begin{tabular}{|l|l|l|}
\hline SESIÓN 6 & $\begin{array}{l}1 \\
\text { HORA }\end{array}$ & RED TEXTUAL Y LECTURAS PARALELAS \\
\hline
\end{tabular}

Docente, la intención de esta sesión es organizar los textos que se leerán durante la secuencia didáctica.

Seguimos en esa orientación a la profesora Claudia Patricia Quintero (2015), quien propone que todo proceso de aprendizaje de las competencias lectoras implica la organización y planeación reflexionada de los textos que leerán los estudiantes a través de lo que ella llama una "Red textual". En esa red, unos textos se van entrelazando con otros. Unos textos conducen a otros. Unos cumplen unas funciones y otros, otras. La profesora Claudia los ha clasificado en 3 grupos.

Proponemos algunos textos, pero usted, docente, puede agregar los que considere pertinentes para el logro de los objetivos de la secuencia didáctica.

Profesor, discuta con sus estudiantes esta Red textual. Si lo considera pertinente puede preparar una reseña corta de cada texto para que ellos se enteren de qué tratan y discutan si los consideran pertinentes. Además acordarán los tiempos que le dedicarán a la lectura de esos textos.

Vea la propuesta de Red textual en la siguiente página. 
Red textual Secuencia didáctica (SD) "Los niños de la guerra"

\begin{tabular}{|c|c|c|}
\hline Tipo de texto & Definición & Ejemplos \\
\hline Texto eje & $\begin{array}{l}\text { Es el texto que vamos a desentrañar } \\
\text { con ojos de escritores, en el que } \\
\text { descubriremos los procedimientos } \\
\text { que lo fundaron para lograr su } \\
\text { comprensión y dominio. }\end{array}$ & $\begin{array}{l}\text { Era como mi sombra (Pilar } \\
\text { Lozano) }\end{array}$ \\
\hline Textos de apoyo & $\begin{array}{l}\text { Son aquellos que ayudan a } \\
\text { comprender al texto eje, con los que } \\
\text { puede tener relaciones intertextuales, } \\
\text { ya sea por los temas que abordan, por } \\
\text { los modos de organización textual, } \\
\text { por el lenguaje, por el léxico, etc. }\end{array}$ & $\begin{array}{l}\text { Contexto histórico del } \\
\text { reclutamiento forzado de } \\
\text { menores en Colombia } \\
\text { (Carlos Sánchez) }^{116} \text {. } \\
\text { GMH. ;Basta ya! pp. 84-87; } \\
\text { 314-322. } \\
\text { Crecimos en la guerra (Pilar } \\
\text { Lozano). }\end{array}$ \\
\hline Textos regalo & $\begin{array}{l}\text { Son la expresión en el aula de que no } \\
\text { siempre hay que volver los textos } \\
\text { objeto de estudio, que la lectura } \\
\text { también se puede vivir teniendo } \\
\text { como única intención la de leer lo } \\
\text { que uno quiere. Esta propuesta, que } \\
\text { recibe otros nombres como lecturas } \\
\text { gratuitas, consiste en proponer } \\
\text { diariamente un texto como "un } \\
\text { regalo, algo que se dona, que se da, } \\
\text { sin esperar nada a cambio... La única } \\
\text { condición es que se lea cinco o diez } \\
\text { minutos antes de comenzar el } \\
\text { trabajo, sin necesidad de que haya } \\
\text { preguntas o comentarios, a no ser } \\
\text { que alguien espontáneamente decida } \\
\text { hacerlo. Se busca simplemente leer } \\
\text { por el placer de leer y del disfrute de } \\
\text { la palabra a través de la lectura en } \\
\text { voz alta". }\end{array}$ & 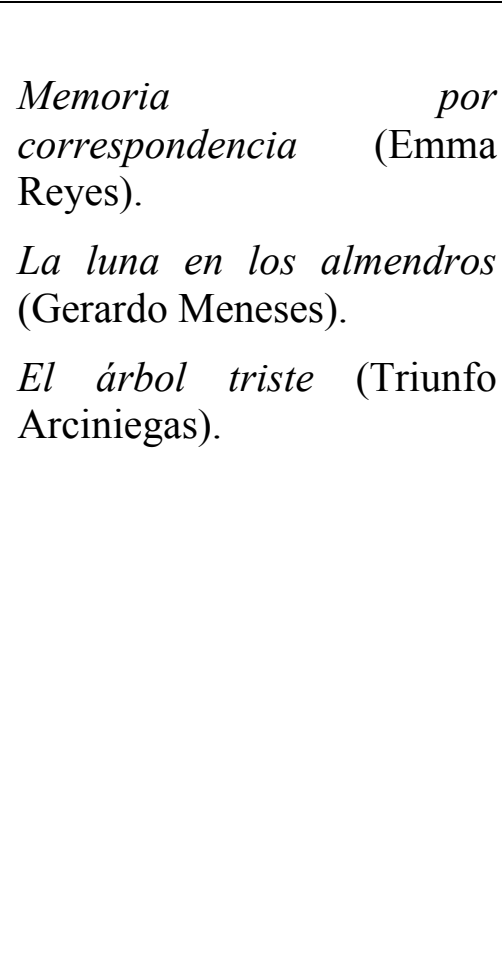 \\
\hline
\end{tabular}

${ }^{116}$ Es el capítulo que hace parte de esta investigación, pp. 98-112 


\begin{tabular}{|l|l|l|}
\hline SESIÓN 7 & $\begin{array}{l}2 \\
\text { HURAS }\end{array}$ & $\begin{array}{l}\text { JUEGO DE ROLES Y LECTURA DEL CAPÍTULO 1 DE } \\
\text { ERA COMO MI SOMBRA }\end{array}$ \\
\hline
\end{tabular}

El "juego de roles" no ha sido bautizado originalmente así por su creadora Mabel Pipkin, si bien lo sugiere en uno de sus trabajos que circula en internet ${ }^{117}$. Lo he denominado de este modo para facilitar su recordación entre los docentes con quienes en varias instituciones hemos implementado la actividad.

Docente, básicamente esta es una estrategia de lectura heterónoma (lectura mediada por el profesor), basada en la cooperación entre lectores más expertos que "jalonan” a los menos expertos. Una típica y calculada actividad didáctica de origen vigotskiano para comprender un texto de manera colectiva.

El docente escoge seis niños. Tres de ellos deberán ser mejores lectores que los otros tres, sobre todo en el nivel inferencial. Los menos expertos comenzarán en los roles menos complejos (lector, detective, adivino); los más expertos en los roles más complejos (preguntón, periodista, sabio).

El resto, los otros estudiantes del salón que están dentro del público, no podrán "soplar” (bueno, eso es complicado, pero el docente intentará hasta donde se pueda, mantener el orden para que se pueda realizar la actividad).

Cada uno de los 6 niños (también los estudiantes que están en el público) deberá tener fotocopia del capítulo 1 de Era como mi sombra. Lo deberán doblar de abajo hacia arriba para poder ir leyéndolo renglón a renglón.

Observemos el esquema 19 para identificar los roles y qué deben hacer los estudiantes mientras leen el texto seleccionado.

\footnotetext{
${ }^{117}$ La teoría y propuesta didáctica de la profesora Mabel Pipkin se puede leer en: http://bit.ly/MRPJnJ. La gráfica que he realizado para explicar el Juego de roles es un resumen esquemático de su tesis de doctorado.
} 


\section{Esquema 19. Juego de roles}

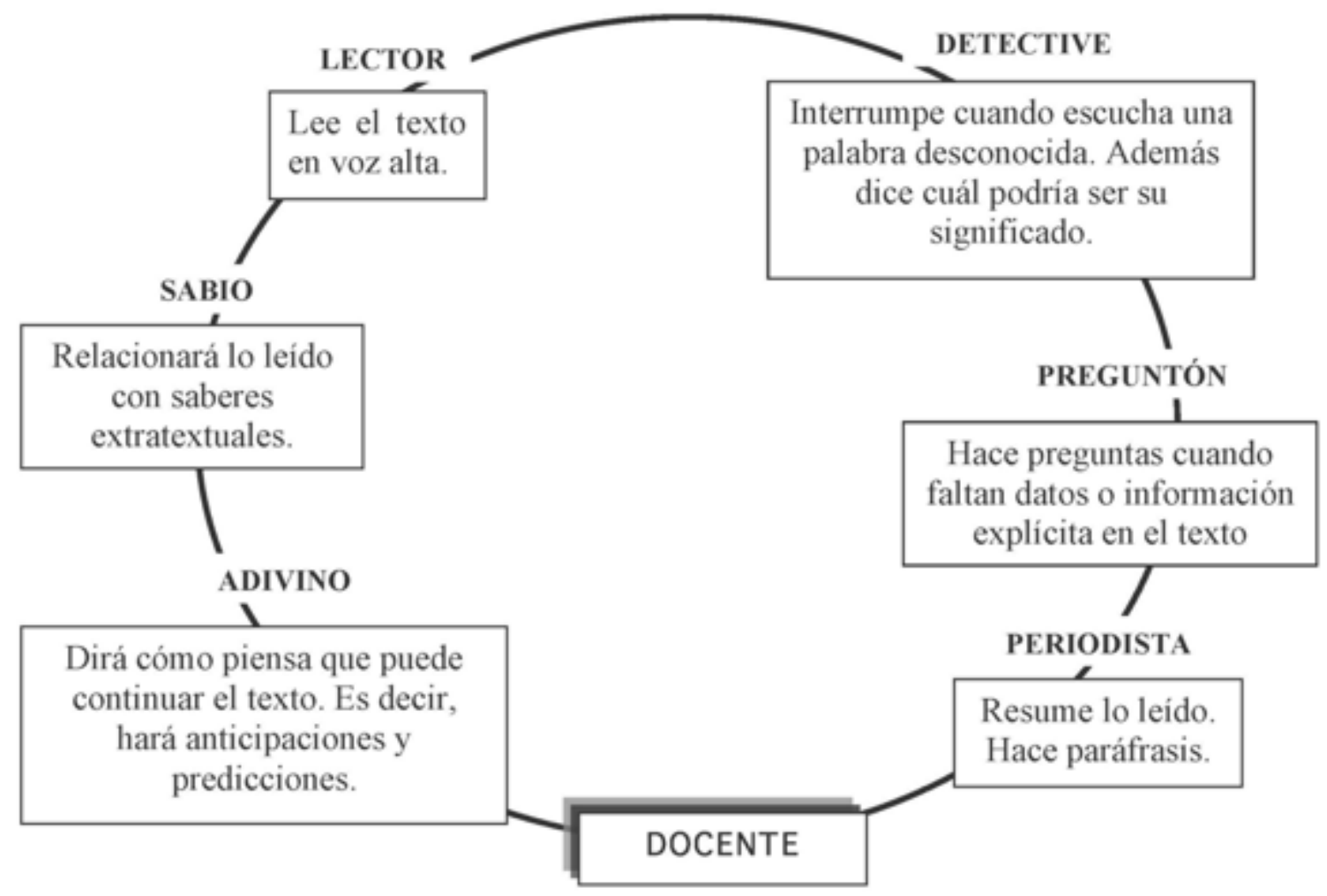

Nota: Adaptado de Pipkin M. et al. (2010). Prácticas de lectura y escritura académicas. Córdoba: Comunicarte.

Pídales a los 6 estudiantes que participan en el Juego de roles -y a todo el curso- que lean con atención los primeros párrafos del capítulo 1 de Era como mi sombra y lo marquen siguiendo estas convenciones.

\begin{tabular}{|l|l|l|}
\hline D: Detective & P. Preguntón & Per: Periodista \\
\hline A: Adivino & S: Sabio & L: Lector \\
\hline
\end{tabular}

El resultado debería ser como el que aparece en la página siguiente.

Si se lee renglón a renglón se podrán observar las diversas intervenciones que deberían hacer cada uno de los estudiantes. El docente deberá estar atento para que los 6 estudiantes que están al frente "entren" cuando les toca. Si alguno no entiende por qué debe participar, se le 
pide al sabio o a un estudiantes del público que le ayude. De este modo un lector más experto ayuda a uno menos experto.

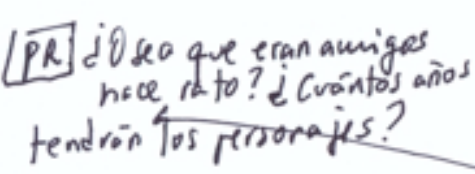

[L] El día que mataron a Martínez Lulián

PR i iavién to mato"? ¿'Porque? ¿Quen \&an Mativez?
A] Julián tambièn lovan a matar.

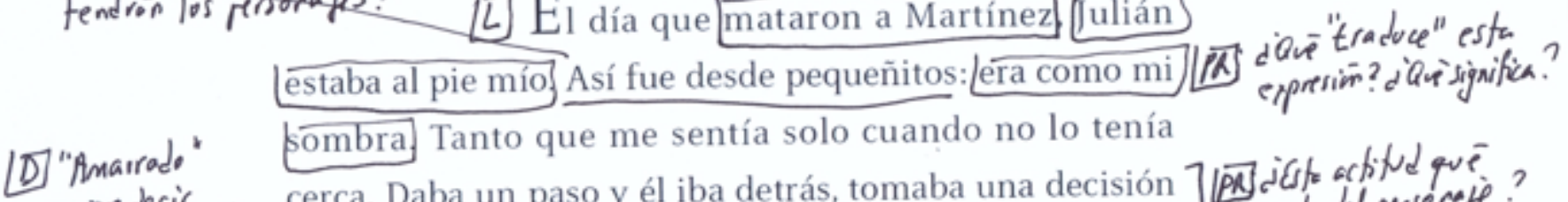

quere decir "regado".

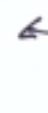

y él la seguía como si fuera suya. Ese día quedó amarrado.

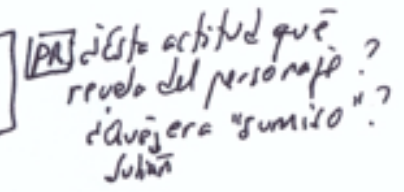
al piso, como yo; después echó a correr, como yo.

[5] Esto porea der [u] Fue un viernes muy de mañana. Bajábamos dando de sicarios. brincos por la loma. Íbamos a ayudar arriar un ganado

[5] Parcen arisco Un grito nos frenó en seco: campesinos

[द] ¡Martínez! ¡Alto ahí! pridarien grito es to en
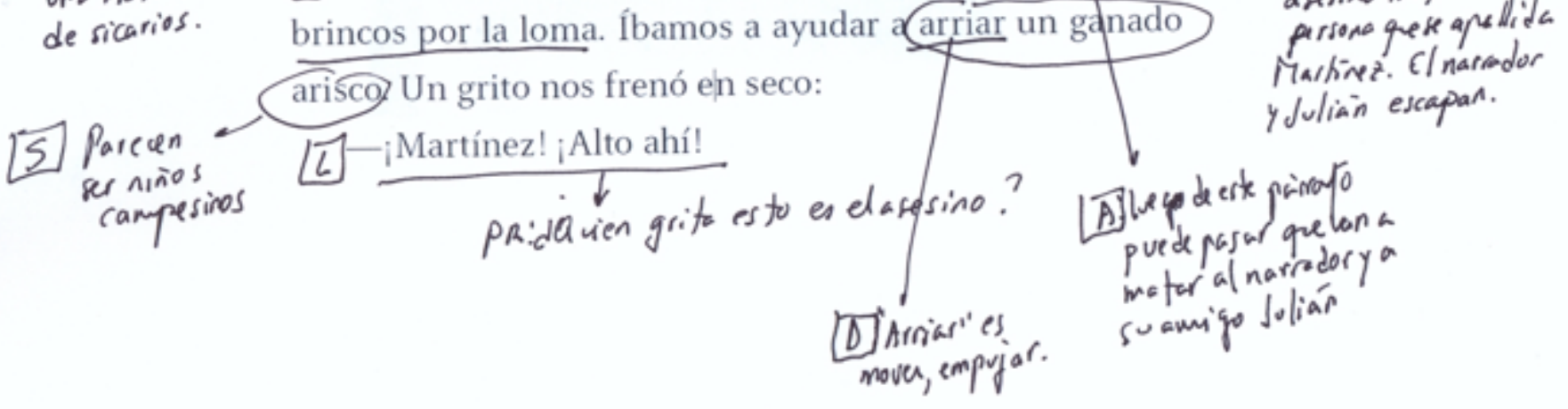
- BER Sintesis: un

En orden, la actividad se realiza así.

1) Docente, informe a los estudiantes que van a participar en el Juego de roles y que este básicamente consiste en que seis estudiantes van a comprender colaborativamente un texto. Cada estudiante representará exclusivamente un rol. Estos roles son:

a. Lector. Es el estudiante que decodifica, es decir, el que lee alfabéticamente en voz alta las oraciones y párrafos. No tendrá que hacer nada más.

b. Detective. Este estudiante interrumpirá la lectura cuando en una oración encuentre una palabra nueva. Tratará de decir cuál es su significado sin mirar el diccionario y solo a través de las pistas contextuales que ofrezca la palabra.

c. Preguntón. Este estudiante luego de leída una frase, hará inferencias, es decir, tratará de explicar algo que no está explícito en el texto. Si el narrador dice: 
“X estaba en la calle y tenía miedo”, el preguntón deberá preguntar: “¿Por qué tenía miedo?" y dar una respuesta posible: “A lo mejor lo iban a robar". Esta información NO está en el texto, sino en la mente del lector.

d. Periodista. El estudiante que interpreta este rol deberá exclusivamente resumir (decir con menos palabras las ideas clave) lo que dice el texto. Al finalizar cada párrafo, el profesor le dirá: "Periodista, resuma en 15 palabras". El estudiante deberá comenzar: "Esta es la historia de...” y decir las más importantes acciones del personaje.

e. Adivino. Este estudiante, luego de leído un párrafo, dirá qué pasará a continuación. Es decir, hace anticipaciones. Los buenos lectores van haciendo hipótesis a medida que van leyendo.

f. Sabio. Este estudiante es el que aporta saberes extratextuales, es decir, el que agrega información que no está en el texto. Si en el cuento aparece que el personaje se encuentra en San Vicente del Caguán, por ejemplo, el sabio intervendrá para agregar que: "El Caguán está en la selva colombiana, al sureste del país, es un municipio de Caquetá. Allá se realizaron los diálogos (fracasados) entre el gobierno Pastrana y la guerrilla de las Farc entre 1999 y 2002”.

2) Docente, como puede apreciar los roles más exigentes son el de preguntón, periodista y sabio. Escoja para ejercerlos a estudiantes que usted considere son más expertos. Los roles menos fuertes son: lector, detective $y$ adivino. Para representarlos seleccione a los niños considerados lectores novatos o inexpertos.

3) Dígales que los seis pupitres que están al frente del tablero sirven para que el estudiante que lo ocupe, exclusivamente representará el rol que le ha sido asignado y no el de otro compañero.

4) Dígales a los seis escogidos que no tengan miedo ni preocupación. Que se si equivocan, mejor, porque así el estudiante sabrá en que no está bien al leer el texto y en qué debe mejorar. Sea claro en decirles al resto de los estudiantes del salón que deberán estar en silencio. Que no se aceptan los “soplones" (en verdad, esto es casi imposible porque todos querrán ayudar a los que están en frente, cuando estos vacilan o tienen dudas). 
5) Entrégueles a todos la fotocopia del fragmento inicial de Era como mi sombra. Adviértales que deberán doblar la hoja para tapar el texto y solo ir leyendo renglón a renglón cuando usted diga.

6) Pídale al lector que comience a leer el fragmento de Era como mi sombra. En la primera oración deberán entrar dos roles: el preguntón para decir que quien narra habla en primera persona y preguntar: “QQuién es Martínez?”; y el adivino para predecir que a Julián también lo podrían matar.

7) Pídale al lector que siga leyendo. En la parte final del primer párrafo deberá intervenir el detective. Si no está atento, dígale: "Detective, te toca participar porque amarrado es una palabra “rara”. ¿Qué es amarrado?”. Si el niño no sabe, pregúntale al sabio si tiene alguna idea. Si no, será necesario mirar en el diccionario y leer el significado de la palabra. Amarrado: atado, "pegado" a algo.

8) Para finalizar el párrafo, pídale intervenir al periodista para que resuma en 15 palabras lo que pasó en el párrafo 1. Si el resumen es incompleto, invite al público participar: “El periodista dijo toda la información clave o falta alguna?”. También pregúntele al adivino: “¿Adivino, qué cree que va a pasar en el párrafo 2?”.

9) Observe en la imagen del texto marcado qué rol entra en cada momento. De ese modo, sucesivamente se puede seguir leyendo el capítulo 1 de Era como mi sombra.

10) También puede pedirle al sabio que haga una crítica o comentario del texto. "Sabio, ¿qué te parece el comienzo - o el final- del capítulo? ¿Qué te gusta más y qué menos?

11) Profesor, la idea es que cuando un estudiante ya domine un rol, pase a uno más complejo. Si es lector, pasará a detective, y luego a adivino. Posteriormente a preguntón y por último a periodista y sabio.

1) Si observa que el grupo de los 6 estudiantes es avanzado, cuando terminen de leer un párrafo, en el siguiente inmediatamente cambian de rol. En la lectura de un solo texto deberían aprender a ejercer los 6 roles.

Docente, usted puede organizar el juego de roles a lo largo de la lectura de Era como mi sombra. En algunos capítulos puede introducir una variante:

- Después de realizar el Juego de roles con los seis estudiantes, puede realizarlo en parejas, sin mover los pupitres en el salón. Escoja un lector experto y un inexperto.

- Entregue la fotocopia con el mismo texto a la pareja de estudiantes. 
- Luego indíqueles que cada estudiante, individualmente, deberá marcar con abreviaturas en el texto dónde entra cada rol. Luego se reunirá con el compañero y contrastarán en qué coincidieron y en qué no. Esto es importante porque le indica al lector inexperto en qué debe mejorar.

Si resumiéramos en un eslogan la propuesta didáctica basada en Mabel Pipkin diríamos que "leer bien es ejercer de manera competente los 6 roles".

Docente, terminada la lectura de los primeros fragmentos de Era como mi sombra, invite a los seis estudiantes participantes del Juego de roles a:

- Explicar cómo se sintieron.

- En qué se confundieron.

- Qué aprendieron.

- Qué roles les parecen más difíciles. ¿Por qué?

- Qué rol nuevo les gustaría interpretar la próxima vez.

Pregunte a los estudiantes del público a quiénes les gustaría participar como voluntarios en el próximo Juego de roles. 


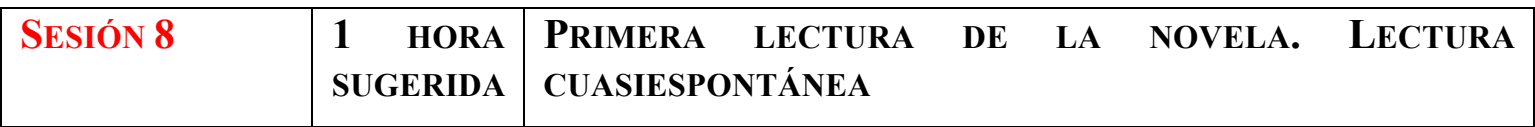

Docente, si bien es cierto que la novela Era como mi sombra (usted lo podrá verificar con sus estudiantes) se lee de "una", el objetivo de la secuencia didáctica no es que sus estudiantes lean "inocentemente" el texto sino que desarrollen habilidades metacognitivas de lectura ${ }^{118}$ y, desde luego, que hagan una apropiación personal del texto.

En esa medida es importante verificar cuáles y cuántos de los estudiantes son lectores heterónomos o lectores autónomos. Las características de estas dos clases de lectores son:

\section{Esquema 20. Manifestaciones de un lector heterónomo frente a uno autónomo}

\begin{tabular}{|l|l|l|}
\hline \multicolumn{1}{|c|}{ Heterónomo } & \multicolumn{1}{c|}{ Autónomo } \\
\cline { 2 - 3 } Lector & $\begin{array}{l}\text { No tiene iniciativa para leer por gusto o interés } \\
\text { propio. Requiere ser "empujado" por el mediador. }\end{array}$ & $\begin{array}{l}\text { Lee por interés propio y busca los materiales que requiere leer. Tiene } \\
\text { objetivos de lectura definidos. }\end{array}$ \\
\cline { 2 - 3 } & $\begin{array}{l}\text { Tiene problemas para comprender globalmente el } \\
\text { (repite lo que un texto. Es lector texto) o se enfoca en } \\
\text { enunciados menores (lectura literal). }\end{array}$ & $\begin{array}{l}\text { Puede dar cuenta del texto tanto en el nivel de comprensión global } \\
\text { (aplica las macrorreglas y usa sus saberes previos para entender el } \\
\text { texto), como en el nivel local (hace paráfrasis e indica dónde dice algo } \\
\text { y quién lo dice) y en el nivel de comprensión crítica (tomas posturas } \\
\text { argumentadas ante lo que dice el texto y reconoce las intenciones de } \\
\text { los autores en los textos). }\end{array}$ \\
\cline { 2 - 3 } & $\begin{array}{l}\text { Le gusta que le lean en voz alta y que el mediador } \\
\text { ofrezca una interpretación del texto. }\end{array}$ & $\begin{array}{l}\text { Lee en silencio, pone en escena todas las habilidades de comprensión y } \\
\text { solo se enfrenta a los retos de intepretación que le impone un texto. }\end{array}$ \\
\cline { 2 - 3 } & $\begin{array}{l}\text { Cuando no entiende un texto lo abandona porque } \\
\text { no sabe qué hacer. }\end{array}$ & $\begin{array}{l}\text { Tiene habilidades metacognitivas para saber qué hacer cuando no } \\
\text { entiende un texto o corregir aquello que entendió mal. }\end{array}$ \\
\hline
\end{tabular}

Nota: Elaboración propia.

En cualquier caso, profesor, creemos que es necesario que ejerza su tarea de mediador. Por tal se entiende al docente que "media", es decir, que prepara los andamiajes para que sus estudiantes puedan aprender con él a comprender un texto, sin que el docente imponga su interpretación. Al respecto hemos escrito:

Cuando un niño, una niña o un joven dice: «No me gusta leer», más que culparlo a él o a ella, se considera que no ha tenido la oportunidad de contar con mediadores de calidad que lo hayan introducido en la cultura escrita. Para

\footnotetext{
${ }^{118}$ La metacognición es el conocimiento autorreflexivo que permite a las personas ser conscientes de sus aprendizajes y de su desarrollo autónomo. Es tener la capacidad de aprender monitoreando de qué modo se aprendió algún conocimiento. Cfs. Galvis S. et al. (2014). Didáctica de la lectura, Bogotá: Alejandría, p. 12.
} 
empezar, es necesario decir que sin mediación (acercar, intervenir, apoyar, jalonar), no hay lectores. Nadie nace lector. Se observa con preocupación el perfil problemático del docente, del bibliotecario, del padre o madre que no lee, que no media, que no interviene en la formación de lectores o no lo considera parte esencial de sus responsabilidades. El objetivo central de la mediación es que esta deje de ser necesaria cuando el lector adquiera mayor autonomía. (Sánchez Lozano, 2014, p. 6).

Docente, en esa orientación, le proponemos planear y llevar a cabo la estrategia (o actividad) didáctica denominada "Lectura cuasiespontánea".

Esta propuesta de lectura, diseñada por el profesor Serafín Barreto ${ }^{119}$, mezcla la lectura heterónoma y la lectura autónoma, pues comienza con un fuerte apoyo del docente (por eso se llama "cuasiespontánea", casi espontánea) y luego debe generar un hábito de lectura autónomo durante al menos 15 minutos diarios, una vez por semana.

\section{LECTURA CUASIESPONTÁNEA \\ Incluso después de terminar la primaria, algunos estudiantes continúan siendo lectores heterónomos, es decir: no logran tener una actitud asertiva hacia la lectura, no comprenden globalmente los textos, y no se acercan a los libros de manera voluntaria. La entrada al educación secundaria supone un momento más exigente, pues verán nuevas asignaturas donde la mayoría de los docentes de todas las áreas pide leer un alto número de páginas por semana. Al no ser lectores autónomos, no tener hábitos de lectura y al seguir siendo lectores literales (o reproductivos, pues repiten lo mismo que dice el texto que leen sin entenderlo), el fracaso académico es inminente. Esta estrategia de la "lectura cuasiespontánea", propuesta por el profesor Serafín Barrero, busca romper ese ciclo y se basa en la idea de que con voluntad, las cosas pueden cambiar. Primero, los estudiantes leerán 15 minutos a la semana acompañados por el profesor. Se espera que, tras varios}

\footnotetext{
${ }^{119}$ El profesor Serafín Barrero trabajó hasta pensionarse en el Colegio de Cafam de Bogotá, donde fue un reconocido profesor de lengua castellana y literatura. Es egresado de la Maestría en Lingüística y Literatura del Instituto Caro y Cuervo. Actualmente reside en Villavicencio. Su correo electrónico es: serafito@,hotmail.com. La estrategia se puede leer en: BARRERO, S. (marzo de 1998). "La lectura cuasiespontánea". En: Educación y Cultura (47) pp. 29-33.
} 
meses, espontáneamente, lo puedan ir haciendo solos durante, mínimo, una hora a la semana.

COMPETENCIAS COMUNICATIVAS QUE SE DESARROLLAN CON ESTA ESTRATEGIA

- Comprensión de textos narrativos de ficción. Lectura literal, pues deberán tener un cuaderno-bitácora de lectura donde podrán copiar en un cuaderno los fragmentos que más les gusten o les impacten de la novela Era como mi sombra, de Pilar Lozano. Lectura inferencial porque aquello que no entiendan claramente, se lo podrán preguntar al profesor. Lectura crítica, ya que en su cuaderno-bitácora de registro de lectura podrán poner sus comentarios (positivos o negativos) sobre los extractos del libro que los "tocaron".

- Producción de textos escritos. En este caso, no escribirán propiamente un texto (con las fases de borrador, revisión y versión definitiva), sino que realizarán copias de extractos de la novela leída. Debe aclararse que esta copia no es exclusivamente mnémica, sino que busca que con base en un fragmento citado, los estudiantes reflexionen alrededor de él y respondan a la pregunta: “¿En qué se aplica a mi vida esto que dice el autor X en su libro Y?".

- Oralidad. Los estudiantes tendrán la oportunidad (si lo desean) de leer en voz alta ante sus compañeros los fragmentos que más les gustaron del libro leído y exponer sus propios comentarios críticos.

GRADOS EN QUE SE PUEDE APLICAR

$7^{\circ}, 8^{\circ}$

TIEMPO APROXIMADO DE DURACIÓN

Entre 15 y 55 minutos

OBJETIVOS

1. Generar experiencias de lectura basadas en la reacción emocional ante los textos.

2. Fomentar progresivamente la lectura autónoma. 
3. Realizar una antología de fragmentos y comentarios críticos con base en la lectura de un libro (en este caso, Era como mi sombra).

REQUISITOS Y MATERIALES

1. Novela Era como mi sombra (2015) de Pilar Lozano.

2. Un cuaderno o libreta que servirá como Bitácora de lectura.

PASOS PARA LA REALIZACIÓN DE LA ESTRATEGIA

Antes

1. Coménteles a los estudiantes que se ha creado una nueva sección de la clase llamada "Lectura cuasiespontánea". Explíqueles el concepto. En términos generales, una actividad espontánea es la que se hace por voluntad propia sin que otra persona intervenga en ningún sentido. En esta (por eso es cuasi = casi) contarán con la asistencia del profesor, para entender aquello que les parece "raro", complejo. El profesor simplemente constatará que se lea en silencio, en el salón, durante un periodo de tiempo fijo, una vez a la semana.

2. Los estudiantes leerán la novela Era como mi sombra, de Pilar Lozano.

3. Acláreles que la idea de la estrategia "Lectura cuasiespontánea" es que los estudiantes se pongan una meta cuantitativa de leer primero 15 minutos en silencio y, luego, aumenten esa proporción de tiempo hasta llegar a 55 minutos.

4. Ojo con lo siguiente: indíqueles que consigan una libreta o un cuaderno para llevar el registro de su lectura de Era como mi sombra. Este cuaderno se convertirá en su Bitácora de lectura. Cada página del cuaderno irá dividida en tres columnas: la primera para citas textuales del pasaje del libro; la segunda para escribir sus comentarios o pensamientos; y la tercera para que puedan escribir cómo se podría aplicar en su vida lo que han leído.

5. Si están de acuerdo, el cuaderno en la primera página puede llevar el título $M i$ Bitácora de lectura (año). Proyecto personal de lectura para 2016. 


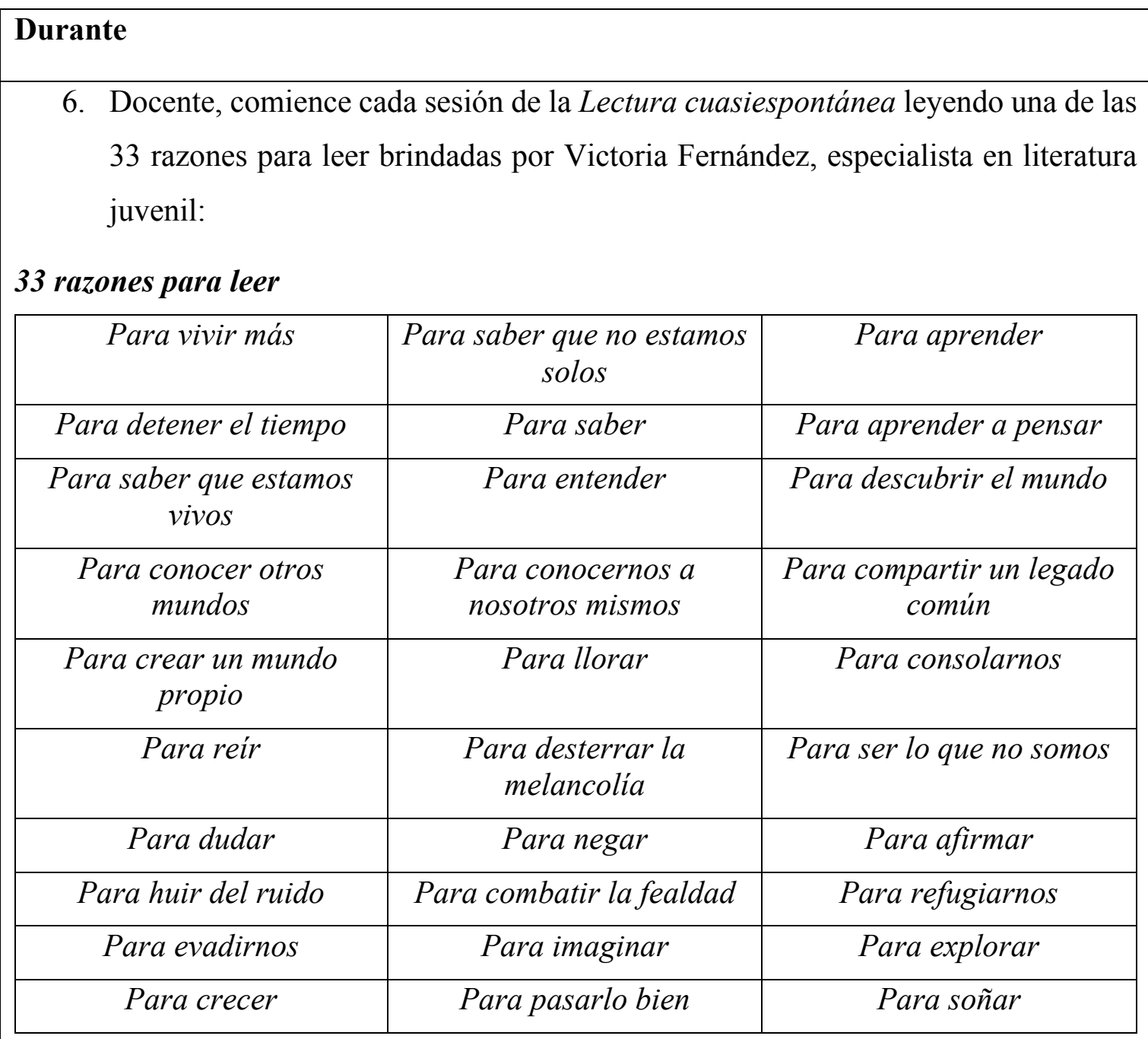

7. También puede pedirles a los estudiantes que comenten cada frase durante un minuto.

8. Con reloj en mano, indíqueles que ha comenzado la sesión de lectura. Deben estar en silencio, no mirar el teléfono celular, ni distraerse en otras actividades. Según lo que usted haya decidido o acordado con sus estudiantes, leerán de 15 a 55 minutos.

9. Pídales que de la novela Era como mi sombra, seleccionen fragmentos breves con sentido completo que les llamen la atención y que los transcriban en la primera columna de su Bitácora de lectura a manera de cita textual directa, con la respectiva referencia de autor, obra y página. 
10. Solicíteles que en la segunda columna de su Bitácora de lectura realicen un comentario crítico del fragmento que les llamó la atención. Explíqueles que el comentario es su respuesta personal ante el texto: ¿qué les dijo?, ¿cómo lo valoran?, ¿qué encuentran de calidad?, ¿cómo les parece el lenguaje?

11. Por último, propóngales en la tercera columna de su Bitácora de lectura hacer una aplicación a su vida personal del mensaje contenido en la cita textual. Como punto de referencia cuantitativo podrían considerar la cifra mínima de diez citas textuales por periodo académico con sus respectivos comentarios y aplicaciones.

\section{Después}

12. Invite a los estudiantes que quieran, a leer un pasaje de su libro, su comentario personal y el modo en que piensan que se puede aplicar a su vida personal.

13. Deberán salir resultados de este tipo:

\section{Cita textual del libro}

"Desde ese día, órdenes que había cumplido sin remordimientos, ni consideraciones, comenzaron a inquietarme”. (Era como mi sombra, p. 62).

\section{Comentario:}

Me parece muy bien que el joven guerrillero desconfie de sus comandantes y vaya asumiendo su propio punto de vista crítico. Eso le permitirá tomar decisiones sin la interferencia de nadie. Una de ellas, desertar y ser libre.

\section{Aplicación a mi vida:}

Yo creo que uno sí debe oír consejos y puntos de vista de los adultos, pero también debe ir asumiendo ideas propias. Obvio que para no caer en el dogmatismo o creer que uno tiene la razón en todo. Lo más importante es que uno no se vuelva un títere al que los adultos manipulan con facilidad como cuando uno era niño. [Juan Pérez, Grado octavo]. 


\begin{tabular}{|l|l|l|}
\hline SESIÓN 9 & $\begin{array}{l}\text { HORA } \\
\text { SUGERIDA }\end{array}$ & $\begin{array}{l}\text { FICHA DE PERSONAJE Y CENTRACIÓN EN ASPECTOS } \\
\text { LOCALES DEL TEXTO }\end{array}$ \\
\hline
\end{tabular}

Docente, la siguiente estrategia busca que luego de leído un capítulo, los estudiantes seleccionen un personaje de la novela Era como sombra y lo analicen con cuidado. La actividad busca que los estudiantes se centren en aspectos locales (no globales) del texto.

NOMBRE DE LA ESTRATEGIA DE ANIMACIÓN LECTORA

\section{Ficha de personaje}

Esta estrategia de animación lectora busca que los estudiantes valoren uno de los ejes de toda buena narración: los personajes. Ulises, Don Quijote, María de Jorge Isaacs, el coronel Aureliano Buendía, son personajes inolvidables porque sintetizan y representan lo interesante y extraña que es la condición humana. A través de esta estrategia se busca que los estudiantes sientan empatía por los personajes de los libros y se concentren en qué los hace tan particulares.

COMPETENCIAS COMUNICATIVAS QUE SE DESARROLLAN CON LA ESTRATEGIA

- Comprensión de textos narrativos de ficción. Lectura literal, inferencial y crítica.

- Producción de textos escritos. En este caso, la escritura de un texto discontinuo o no secuencial (está organizado en secciones) de carácter descriptivo.

- Oralidad. Los estudiantes comentarán en voz alta su Ficha de personaje. Respetarán los turnos para participar. Leerán en voz alta lo que han escrito.

GRADOS EN QUE SE PUEDE APLICAR

$7^{\circ}, 8^{\circ}$

TIEMPO APROXIMADO DE DURACIÓN

55 minutos

OBJETIVOS

1. Fortalecer las habilidades de lectura comprensiva al centrar la atención en los personajes centrales de un texto narrativo de ficción (protagonista, coprotagonista o antagonista).

2. Desarrollar habilidades para la escritura de textos descriptivos. 
3. Estimular la empatía del lector con los personajes de una historia.

REQUISITOS Y MATERIALES

1. Capítulo 11 de Era como mi sombra. Allí se nos cuenta cómo es Matilde, la niña guerrillera.

2. Hojas con la Ficha de personaje para completar. Una por cada estudiante.

3. Tablero (o videobeam si cuenta con este recurso en su colegio).

4. El espacio para la lectura es el salón. Sin embargo, si hay mucho ruido, busque un lugar tranquilo en el colegio para que usted, docente, pueda leer sin interferencias. Puede ser la biblioteca escolar o un parque.

PASOS PARA LA REALIZACIÓN DE LA ESTRATEGIA

Antes

1) Si los estudiantes tienen el libro Era como mi sombra, muy bien. Si no, docente, saque una fotocopia del capítulo 11 (pp. 70-74) para entregar a cada estudiante.

2) Prepare hojas con la Ficha de personaje, listas para ser completadas por sus estudiantes. El siguiente es un modelo, pero usted tiene la libertad para componer la ficha de la manera en que lo considere pertinente. 


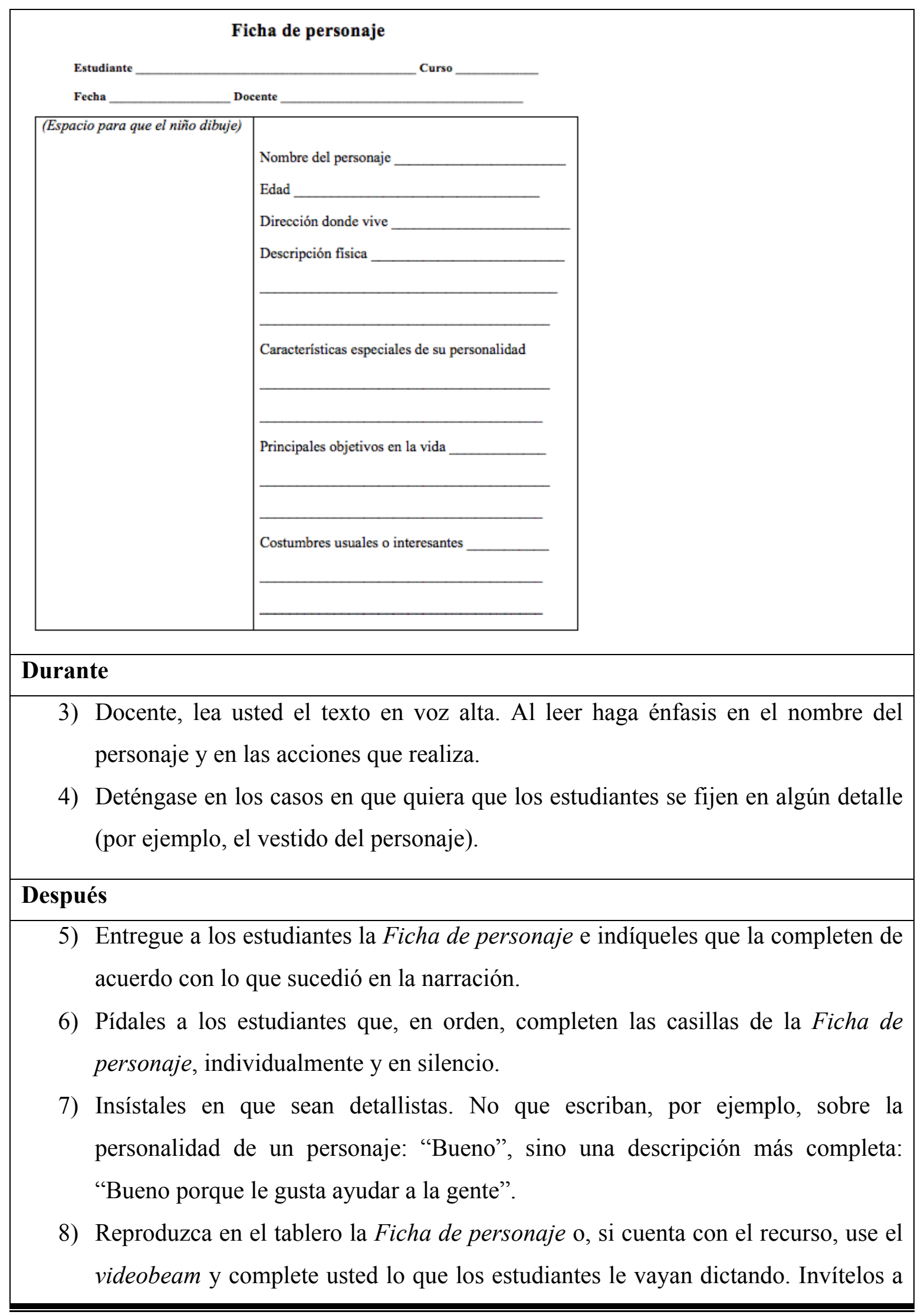


compartir la Ficha de personaje en voz alta, delante de sus compañeros. Si alguno ya completó una sección de la ficha, el siguiente tendrá que agregar algo nuevo.

9) Permita que todos los estudiantes participen en la estrategia.

VARIACIONES DE ESTA ESTRATEGIA

1. Agregue secciones a la Ficha de personaje como las siguientes: lugares que conoce, amigos, cosas que no le gusta hacer, viajes que ha realizado, deporte que le gusta, momento en que ha estado triste, relación que tiene con sus padres, pasatiempo preferido, etc.

2. Busque que, aunque la información no aparezca explícitamente en el relato, los estudiantes puedan inferir nueva información sobre el personaje que escogieron analizar, y que tenga sustento en el texto leído. Pregúnteles: “¿De dónde deduces lo que dices?".

3. Pueden escoger para realizar la Ficha de personaje no solo un personaje sino varios a la vez.

4. Los estudiantes pueden trabajar en parejas.

5. También podrían hacer una cartelera con el dibujo del personaje y su ficha en un pliego de papel periódico o cartulina. Después, podrán exponerla en un lugar visible del salón.

6. Igualmente se puede hacer una Antología de Fichas de personajes, impresa o digital, y subirlas a repositorios virtuales de textos como Scribd (https://es.scribd.com), Issuu ( (http://es.slideshare.net). Luego, usted puede enviarles el enlace a los padres para que vean el trabajo de sus hijos.

Otra alternativa para que los estudiantes sientan empatía con el personaje seleccionado (que puede ser el protagonista, un antagonista o los personajes secundarios) es completar el Test Proust. Este es un cuestionario que el gran escritor francés (Marcel Proust, 1871-1922) le enviaba a sus recientes amigos con el fin de conocerlos en detalle. 


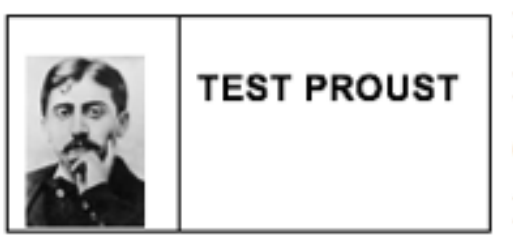

Estudiante:

Personaje seleccionado:

Curso:

Fecha:

+

El principal rasgo de mi carácter

La cualidad que más admiro en un hombre

La cualidad que más admiro en una mujer

Lo que yo más aprecio de mis amigos

Mi principal defecto

Mi hobby preferido

El sueño que quiero alcanzar

El lugar o país que quiero conocer

El color que prefiero

La flor que amo

Aquello que me gusta leer

Mis héroes y heroínas en la ficción

Mis héroes y heroinas en la realidad

Lo que detesto sobre todas las cosas

El cambio o reforma que yo apoyaría

Cómo me gustaría morir

Estado presente de mi espíritu

Mi eslogan en la vida 


\begin{tabular}{|l|l|l|}
\hline SESIÓN 10 & $\begin{array}{l}2 \\
\text { SUGERIDAS }\end{array}$ & $\begin{array}{l}\text { VERIFICACIÓN DE DOMINIO DE LAS HABILIDADES } \\
\text { DE COMPRENSIÓN TEXTUAL }\end{array}$ \\
\hline
\end{tabular}

Esta sesión puede parecer formal o acartonada, pero considero necesario evaluar si los estudiantes mientras leían el texto, pusieron en escenas las habilidades de lectura requeridas para dialogar con una novela. Docente, si usted lo considera pertinente, inclúyala dentro del desarrollo de la secuencia o si no, pase a la actividad propuesta en las Sesión $11^{120}$.

VERIFICACIÓN DE HABILIDADES DE MEMORIA A CORTO PLAZO

(Capítulos 1 a 6 - Páginas 3 a la 42 de Era como mi sombra)

1) Recuerda los principales acontecimientos que suceden en esta parte de la novela.

\begin{tabular}{|l|l|l|l|l|}
\hline & & & & \\
\hline & & & & \\
\end{tabular}

2) Responde estas preguntas.

a. ¿Quién era Martínez?

b. ¿Cuando el narrador habla de allá, a qué se refiere?

c. ¿Por qué Julián nunca pudo ir a la escuela?

d. ¿Qué hizo la profesora Elvira para evitar que sus estudiantes sufrieran un accidente grave por culpa de las minas "quiebrapatas"?

\footnotetext{
${ }^{120}$ Esta verificación de las habilidades de comprensión lectora se basa en la Guía de aula que realicé para Ediciones SM. Se puede consultar acá: http://bit.ly/1LuVLSG
} 
3) ¿Quién dijo qué? Escríbelo en el paréntesis.

\begin{tabular}{|c|c|c|}
\hline a. & Abuela & ( ) ¿Dónde está la guerrilla? Usted y sus muchachos lo saben. \\
\hline b. & Tío & $\begin{array}{l}\text { ( ) Quiero una única ley. No me importa cuál sea, pero que sea un } \\
\text { solo patrón y a ese nos acogemos. }\end{array}$ \\
\hline c. & Julián & ( ) Mis planes de seguir estudiando ya no existían. \\
\hline d. & Niño narrador & ( ) Los árboles hablan. \\
\hline e. & Teniente & ( ) ¡Hermano, no jodan así a la población civil! \\
\hline
\end{tabular}

(Capítulos 7 a 13 - Páginas 43 a la 86 de Era como mi sombra).

4) Completa el cuadro según la historia.

\begin{tabular}{|l|l|l|}
\hline & ¿Quién era? & ¿Qué hace importante en esta sección? \\
\hline El Calvo & & \\
\hline Mario & & \\
\hline Mayerly & & \\
\hline
\end{tabular}

5) Lee el fragmento del recuadro.

"Pasaron los meses y el uniforme hecho a su medida de niña le fue quedando cortico. Se fue poniendo más bonita, flaca, bien entalladita, el cabello largo le llegaba a media nalga. Dejó de ser la mascota del grupo. Pero no alcanzó a cumplir los dieciséis. La mandaron a hacer inteligencia y ahí la agarraron.”.

Responde las preguntas.

\begin{tabular}{|c|c|c|}
\hline ¿De quién se habla? & $\begin{array}{c}\text { ¿Por qué era considerada } \\
\text { la "mascota del grupo"? }\end{array}$ & $\begin{array}{c}\text { ¿Qué quiere decir que no } \\
\text { alcanzó a cumplir los 16? }\end{array}$ \\
\hline & ¿Qué es "hacer \\
inteligencia”? & ¿Quién la "agarró”? & $\begin{array}{c}\text { ¿Qué le sucedería después } \\
\text { de que la agarraron? }\end{array}$ \\
\hline & & \\
\hline
\end{tabular}

6) ¿A qué se refiere el niño narrador? Escríbelo en el recuadro.

Sí, allá el tiempo para jugar se acaba.

7) Enumera las tres impresiones más fuertes que tuviste al leer los capítulos 7 al 13.

\begin{tabular}{|l|l|l|}
\hline Impresión 1 & Impresión 2 & Impresión 3 \\
\hline & & \\
\hline
\end{tabular}


VERIFICACIÓN DE LAS HABILIDADES DE PROCESAMIENTO DE LA INFORMACIÓN EXPLÍCITA (COMPRENSIÓN LITERAL)

8) Escribe adjetivos para calificar a estos personajes.

Niño narrador

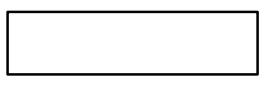

Julián
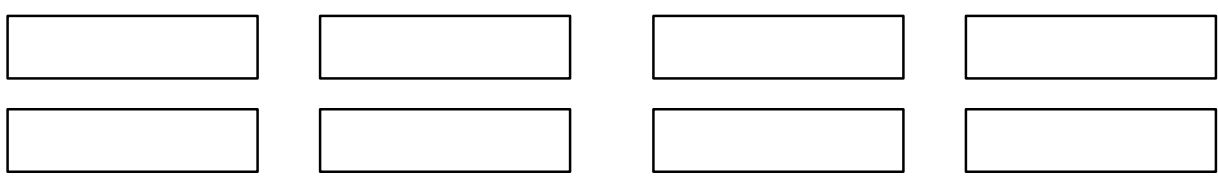

El Tío Pedro
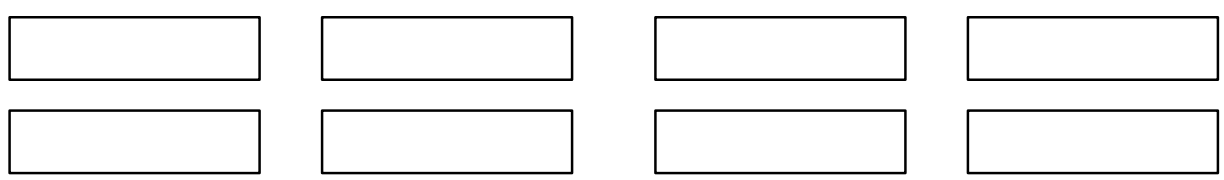

Mamá del narrador
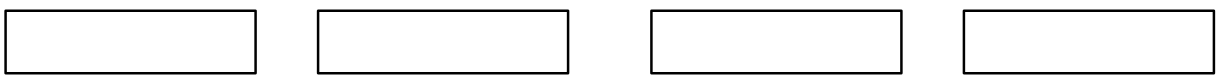

9) Escribe el hecho más importante que ocurre en cada parte de Era como mi sombra.

\begin{tabular}{|lll|}
\hline $\begin{array}{l}\text { Presentación } \\
\text { la historia }\end{array}$ \\
\hline $\begin{array}{l}\text { Resolución } \\
\text { conflicto }\end{array}$ \\
\hline
\end{tabular}

10) Explica por qué se mencionan en la novela:

\begin{tabular}{|l|l|}
\hline El cusumbo & \\
\hline La pata del arcoíris & \\
\hline Las rosas rojas & \\
\hline El piqui-cuarta & \\
\hline
\end{tabular}

11) Responde verdadero (V) o falso (F) según corresponda.

\begin{tabular}{|c|c|c|c|}
\hline $\begin{array}{c}\text { La profesora Elvira } \\
\text { intentó evitar que } \\
\begin{array}{c}\text { sus estudiantes se } \\
\text { fueran para la } \\
\text { guerrilla. }\end{array}\end{array}$ & $\begin{array}{c}\text { Julián cuidaba a su } \\
\text { abuela, a mamá } \\
\text { enferma y a su } \\
\text { hermana } \\
\text { discapacitada. }\end{array}$ & $\begin{array}{c}\text { Al tío Pedro le } \\
\text { gustaba la música } \\
\text { "salsa". }\end{array}$ & $\begin{array}{c}\text { La mamá de } \\
\text { Mayerly les ayuda a } \\
\text { los "muchachos" a } \\
\text { fugarse de la } \\
\text { guerrilla. }\end{array}$ \\
\hline
\end{tabular}


VERIFICACIÓN DE LAS HABILIDADES DE PROCESAMIENTO DE LA INFORMACIÓN IMPLÍCITA (COMPRENSIÓN INFERENCIAL)

12) Marca con una $X$ los temas que toca la novela Era como sombra.

\begin{tabular}{|l|l|l|l|l|l|l|l|l|l|}
\hline $\begin{array}{l}\text { La pobreza en } \\
\text { el campo }\end{array}$ & $\begin{array}{l}\text { La pérdida de } \\
\text { la niñez }\end{array}$ & $\begin{array}{l}\text { El conflicto } \\
\text { armado }\end{array}$ & \multicolumn{2}{|l|}{$\begin{array}{l}\text { El primer amor } \\
\text { arma injusticia } \\
\text { social }\end{array}$} \\
\hline
\end{tabular}

13) Comenta estas frases dichas por los personajes.

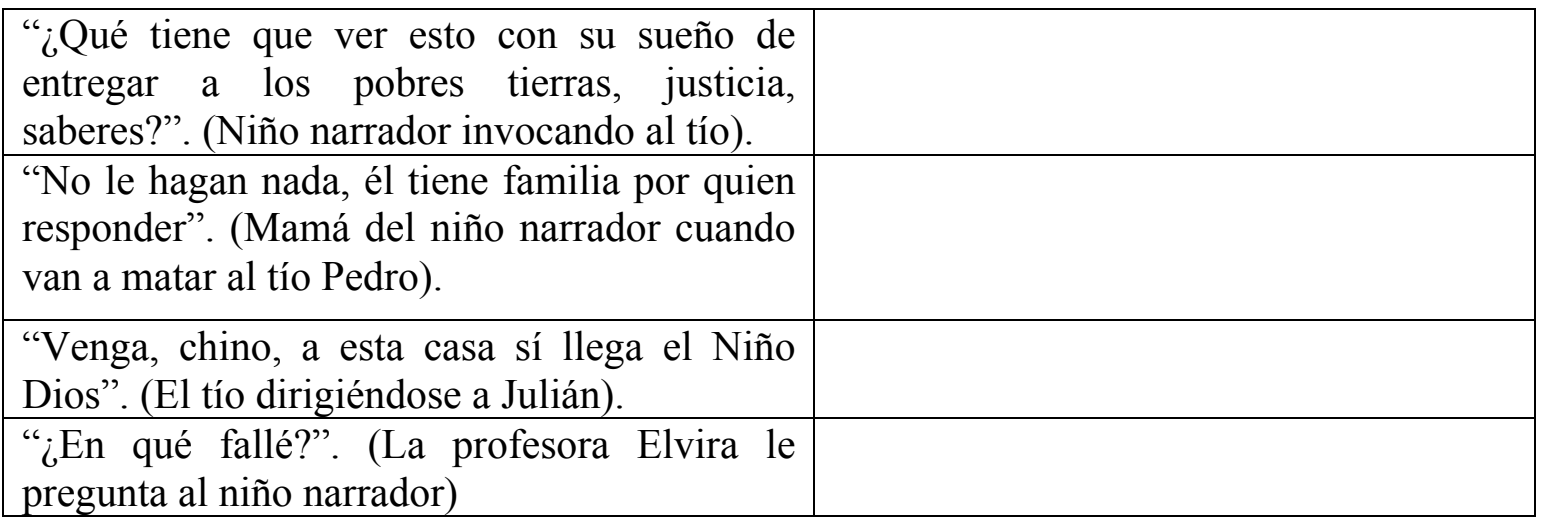

14) Marca con una $X$ si de la novela se pueden o no inferir estas afirmaciones.

\begin{tabular}{|l|l|l|}
\hline Inferencias & SÍ & NO \\
\hline La profesora Elvira es valerosa y es una buena maestra. & & \\
\hline $\begin{array}{l}\text { El tío del niño narrador es el responsable de que su sobrino se vaya a la } \\
\text { guerrilla. }\end{array}$ & & \\
\hline $\begin{array}{l}\text { Varias entidades del Estado se hicieron presentes para proteger a los } \\
\text { niños de la violencia. }\end{array}$ & & \\
\hline La pobreza también es un problema de oportunidades. & & \\
\hline $\begin{array}{l}\text { La guerrilla reclutó niños como combatientes, violando leyes } \\
\text { internacionales. }\end{array}$ & & \\
\hline
\end{tabular}

15) Escribe tres deseos que el narrador de la novela podría tener para el futuro.

\begin{tabular}{|l|l|}
\hline Deseo 1 & \\
\hline Deseo 2 & \\
\hline Deseo 3 & \\
\hline
\end{tabular}


VERIFICACIÓN DE LAS HABILIDADES DE COMPRENSIÓN CRÍTICA DE LA INFORMACIÓN

16) Explica en qué situaciones de la novela se presentan estos valores.

\begin{tabular}{|l|l|}
\hline Valor & Situación \\
\hline La solidaridad & Cuando... \\
\hline El amor a la madre & \\
\hline El sentido de justicia & \\
\hline La dignidad humana & \\
\hline
\end{tabular}

17) Califica con estrellas la novela Era como mi sombra.

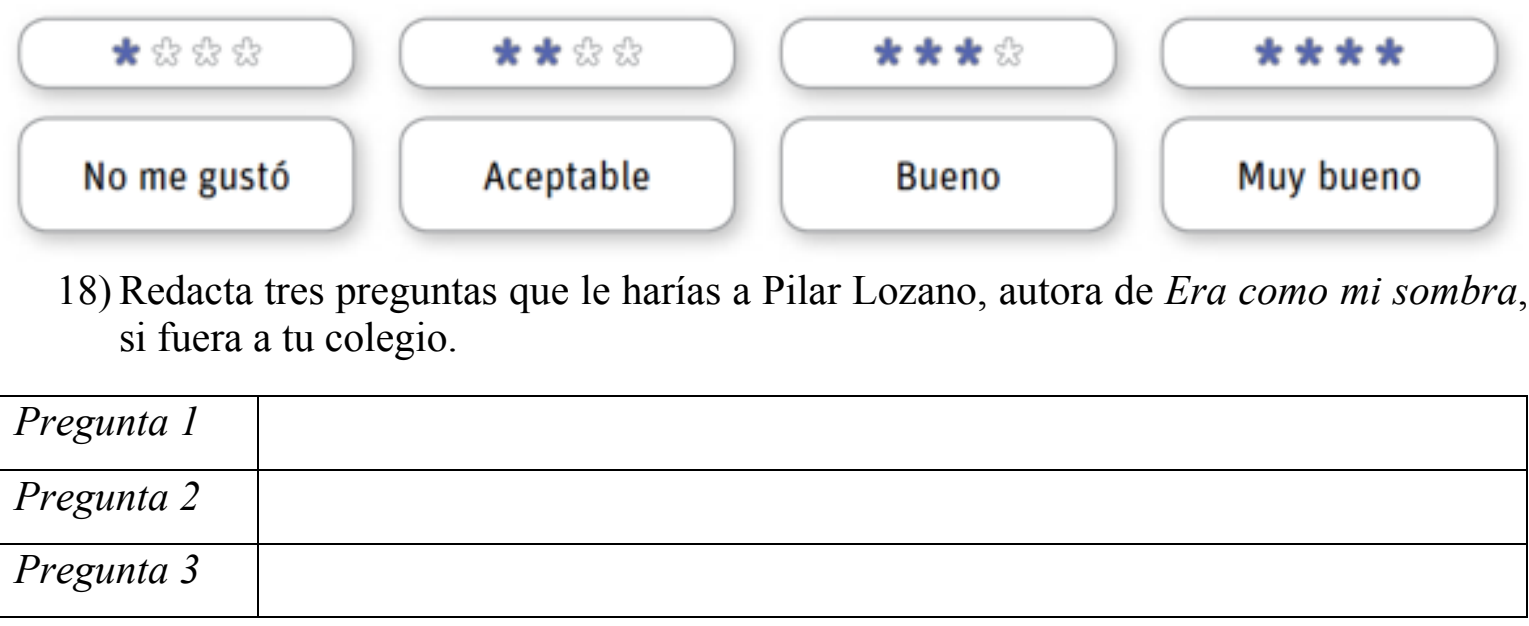

19) Desarrolla esta idea a partir de tu propia mirada del problema.

Los niños, niñas y adolescentes no deben estar en la guerra porque...

20) Escribe un mensaje al Presidente de Colombia pidiéndole proteger los derechos de los niños que han sido víctimas del reclutamiento forzado en grupos armados. Sigue el esquema de la página siguiente.

$$
\text { http://bit.ly/1HEmsRh }
$$




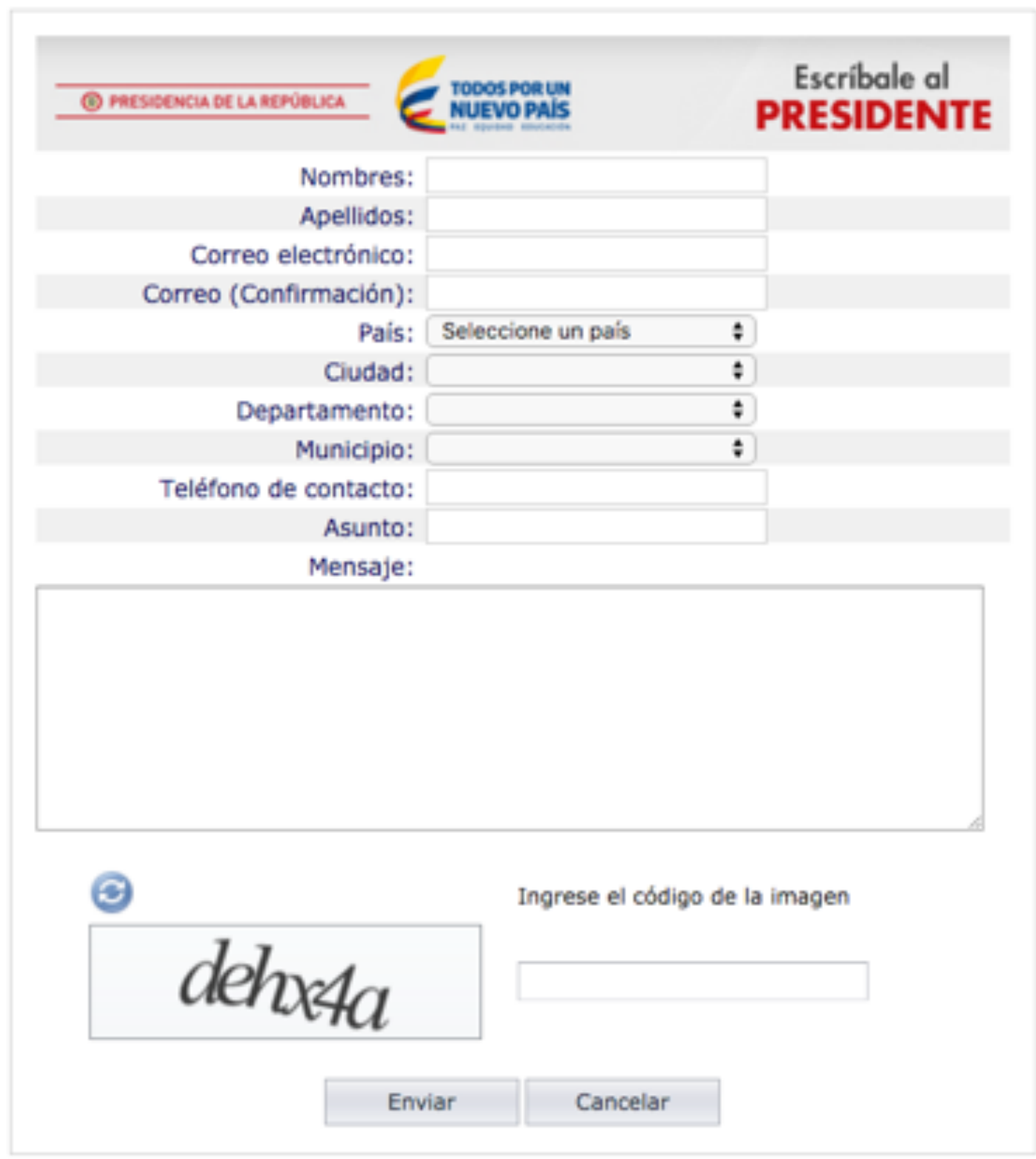




\begin{tabular}{|l|l|l|}
\hline SESIÓN 11 & $\begin{array}{l}2 \\
\text { HORAS } \\
\text { SUGERIDAS }\end{array}$ & $\begin{array}{l}\text { DESARROLLO DE LA LECTURA CRÍTICA. ESCRITURA } \\
\text { DE UN COMENTARIO (1' }\end{array}$ \\
\hline
\end{tabular}

Docente, es necesario que la secuencia didáctica incluya una propuesta de escritura procesual

(borrador, primera versión, revisión, segunda versión, segunda revisión, versión final para circular) en la que los estudiantes expresen su conocimiento y apropiación de Era como mi sombra y enfrenten de manera crítica el texto dando sus opiniones.

Le proponemos trabajar el comentario con las pautas que hemos elaborado con el grupo de docentes del Colegio Cambridge.

\section{Cuadro 3. El comentario ( $\left(1^{\mathrm{a}}\right.$ parte)}

\begin{tabular}{|c|c|c|}
\hline $\begin{array}{l}\text { Momentos de la } \\
\text { actividad }\end{array}$ & $\begin{array}{l}\text { Lo que se espera de } \\
\text { los estudiantes... }\end{array}$ & Consignas del docente... Posibles intervenciones \\
\hline $\begin{array}{l}\text { Momento 1. } \\
\text { Teniendo como } \\
\text { punto de partida } \\
\text { el formato sobre } \\
\text { comentario } \\
\text { realizado por } \\
\text { Carlos Sánchez } \\
\text { (ver abajo) se } \\
\text { realiza un primer } \\
\text { acercamiento a lo } \\
\text { que significa el } \\
\text { comentario. Para } \\
\text { este momento los } \\
\text { estudiantes no } \\
\text { reciben ningún } \\
\text { tipo de apoyo } \\
\text { diferente al } \\
\text { formato. Es decir } \\
\text { que el docente no } \\
\text { da pautas previas, } \\
\text { ni explicaciones. } \\
\text { La intención es } \\
\text { que los } \\
\text { estudiantes se } \\
\text { acerquen a la } \\
\text { técnica escritural } \\
\text { sin tener un } \\
\text { contexto previo. }\end{array}$ & $\begin{array}{l}\text { Realización de un } \\
\text { primer esbozo de } \\
\text { comentario. } \\
\text { Realizarlo sin } \\
\text { recibir pautas, } \\
\text { apoyo o guías } \\
\text { metodológicas. }\end{array}$ & $\begin{array}{l}\text { El día de hoy iniciaremos un trabajo de interpretación escrita } \\
\text { del libro Era como mi sombra. Vamos a comentar la novela, } \\
\text { a contar sobre ella. } \\
\text { Hasta el momento hemos leído el libro aprendiendo } \\
\text { explícitamente algunos mecanismos o estrategias para } \\
\text { mejorar nuestra comprensión del libro. También tuvieron la } \\
\text { oportunidad leer algunos de capítulos autónomamente } \\
\text { mediante estrategias como el Juego de roles, la Lectura } \\
\text { cuasiespontánea y la Ficha de personaje. Hemos realizado } \\
\text { un trabajo fuerte sobre la información del libro y buscado e } \\
\text { implementado formas de entender lo que dice el texto, } \\
\text { realizado inferencias sobre la información explícita o } \\
\text { implícita del texto. Ahora es el momento de poner nuestra } \\
\text { voz sobre el libro. Una cosa es lo que el libro nos dice y otra } \\
\text { diferente es lo que nosotros podemos decir del libro. Eso es } \\
\text { comentar el libro. } \\
\text { Traigo un formato que ustedes van a trabajar. Se trata de dar } \\
\text { respuesta a las preguntas o solicitudes que nos hace el } \\
\text { formato, lo llenaremos con la información que nosotros } \\
\text { tenemos de la novela Era como mi sombra, ahora que ya } \\
\text { terminamos su lectura. Necesito que lo hagan solos, sin que } \\
\text { les dé mayores explicaciones. Después leeremos los } \\
\text { comentarios y veremos qué podemos mejorar. } \\
\text { Para este trabajo cuentan con dos horas. }\end{array}$ \\
\hline
\end{tabular}

Nota: Adaptado de la SD “Escribir como lectores”. Recuperado de: http://bit.ly/1Lri2nz. 
Cuadro 4. Formato para elaborar el primer borrador del comentario

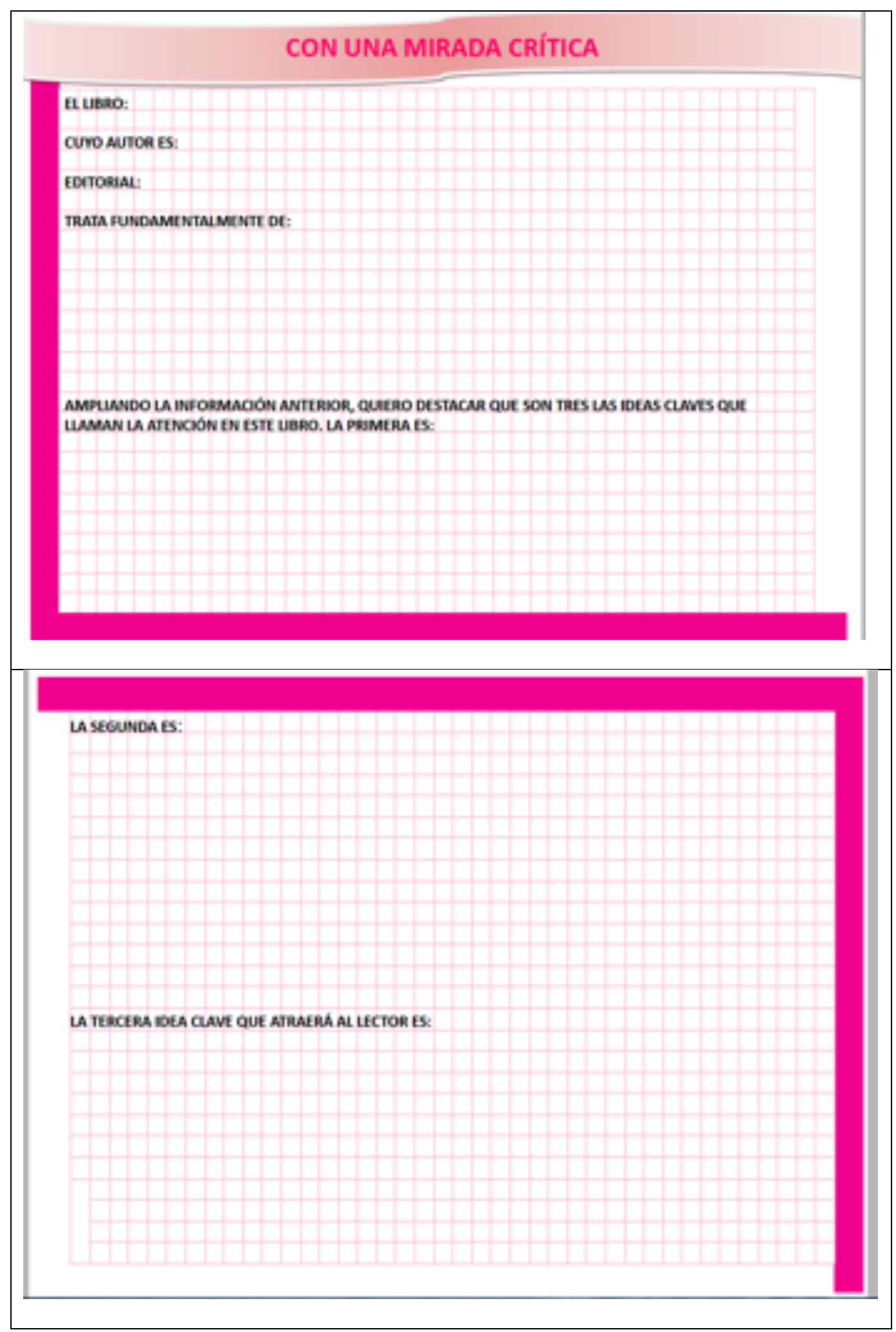




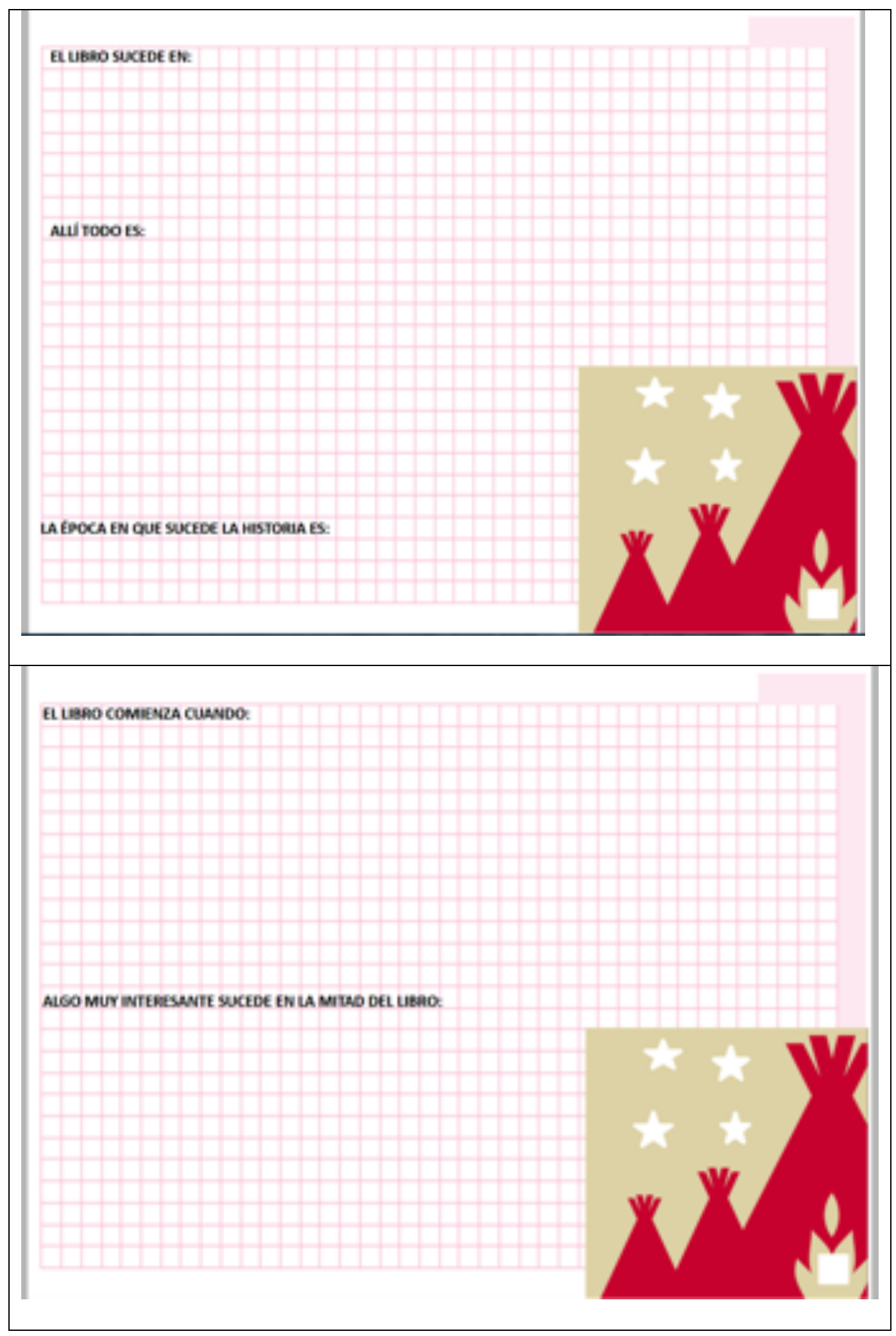




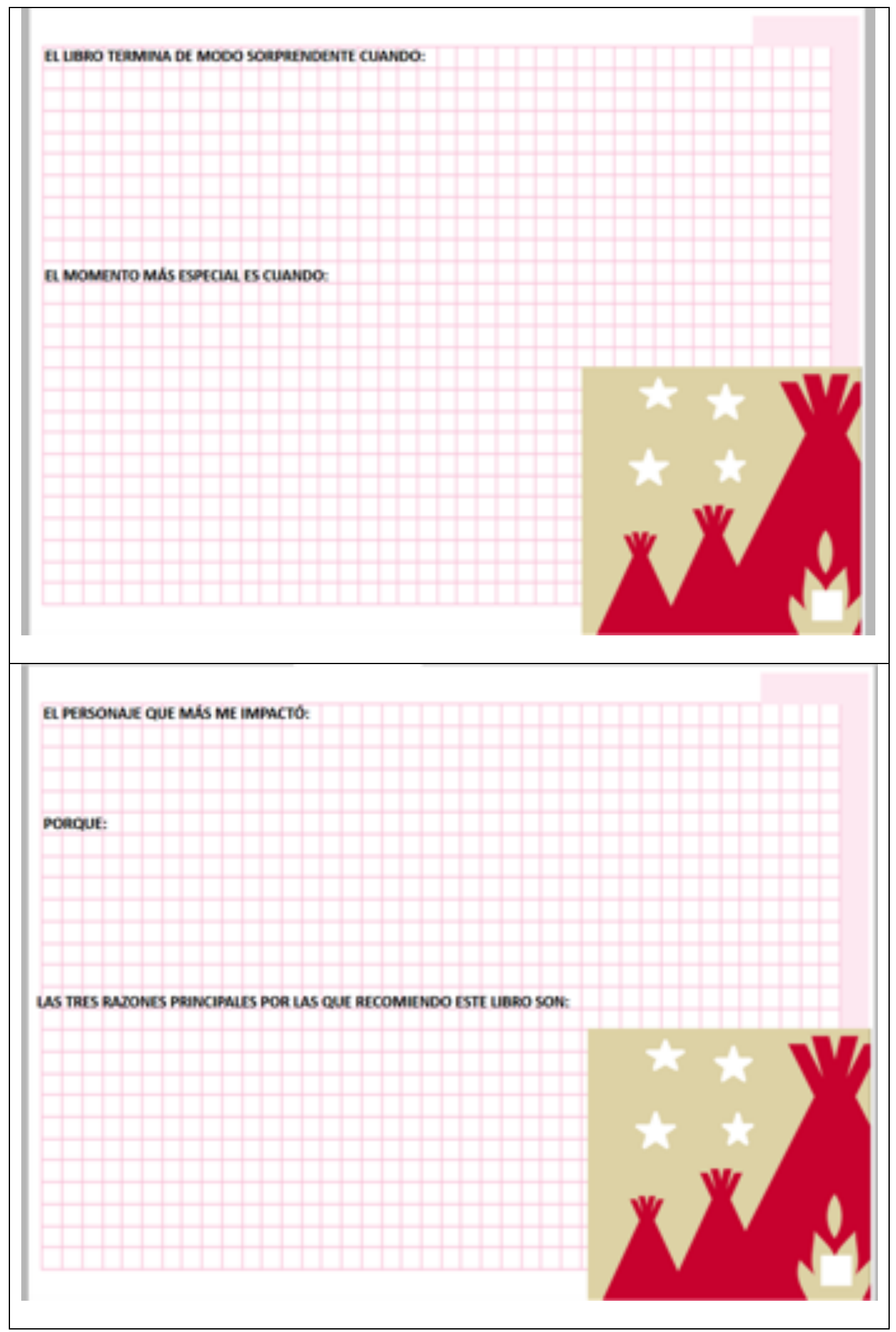

Nota: Elaboración propia. 


\begin{tabular}{|l|l|lll|}
\hline SESIÓN 12 & 2 & HORAS & DESARROLLO DE & LA LECTURA CRÍTICA. \\
& SUGERIDAS & ESCRITURA DE UN COMENTARIO (2a PARTE) \\
\hline
\end{tabular}

Docente, en esta sesión la idea es que usted revise algunos de los borradores de comentario que hicieron en la sesión anterior y a continuación comiencen a escribir una segunda versión, la revisen con la ayuda de una rúbrica (ver siguiente página), y reescriban la versión final.

\section{Cuadro 5. El comentario ( $2^{\mathrm{a}}$ parte)}

\begin{tabular}{|c|c|c|}
\hline $\begin{array}{l}\text { Momentos de la } \\
\text { actividad }\end{array}$ & $\begin{array}{l}\text { Lo que se espera } \\
\text { de los } \\
\text { estudiantes... }\end{array}$ & Consignas del docente... Posibles intervenciones \\
\hline $\begin{array}{l}\text { Momento 1. } \\
\text { Análisis de una } \\
\text { reseña corta paso a } \\
\text { paso: el título, la } \\
\text { organización de los } \\
\text { párrafos y las } \\
\text { oraciones, la forma } \\
\text { como se adjetiva y el } \\
\text { uso de recursos } \\
\text { intertextuales. } \\
\text { Página de apoyo: } \\
\text { Templo de las mil } \\
\text { puertas } \\
\text { http://www.eltemplo } \\
\text { delasmilpuertas.com } /\end{array}$ & $\begin{array}{l}\text { Interiorizar } \\
\text { estrategias que } \\
\text { permitan ganar } \\
\text { habilidades en la } \\
\text { técnica del } \\
\text { resumen, a partir } \\
\text { de las } \\
\text { macrorreglas de } \\
\text { Van Dijk y de la } \\
\text { crítica textual } \\
\text { fundamentada } \\
\text { en estrategias de } \\
\text { argumentación } \\
\text { oral. } \\
\text { Tener un punto } \\
\text { de referencia a } \\
\text { partir del cual } \\
\text { poder mejorar y } \\
\text { corregir sus } \\
\text { primeras } \\
\text { versiones de } \\
\text { comentario } \\
\text { realizadas en la } \\
\text { sesión anterior. }\end{array}$ & 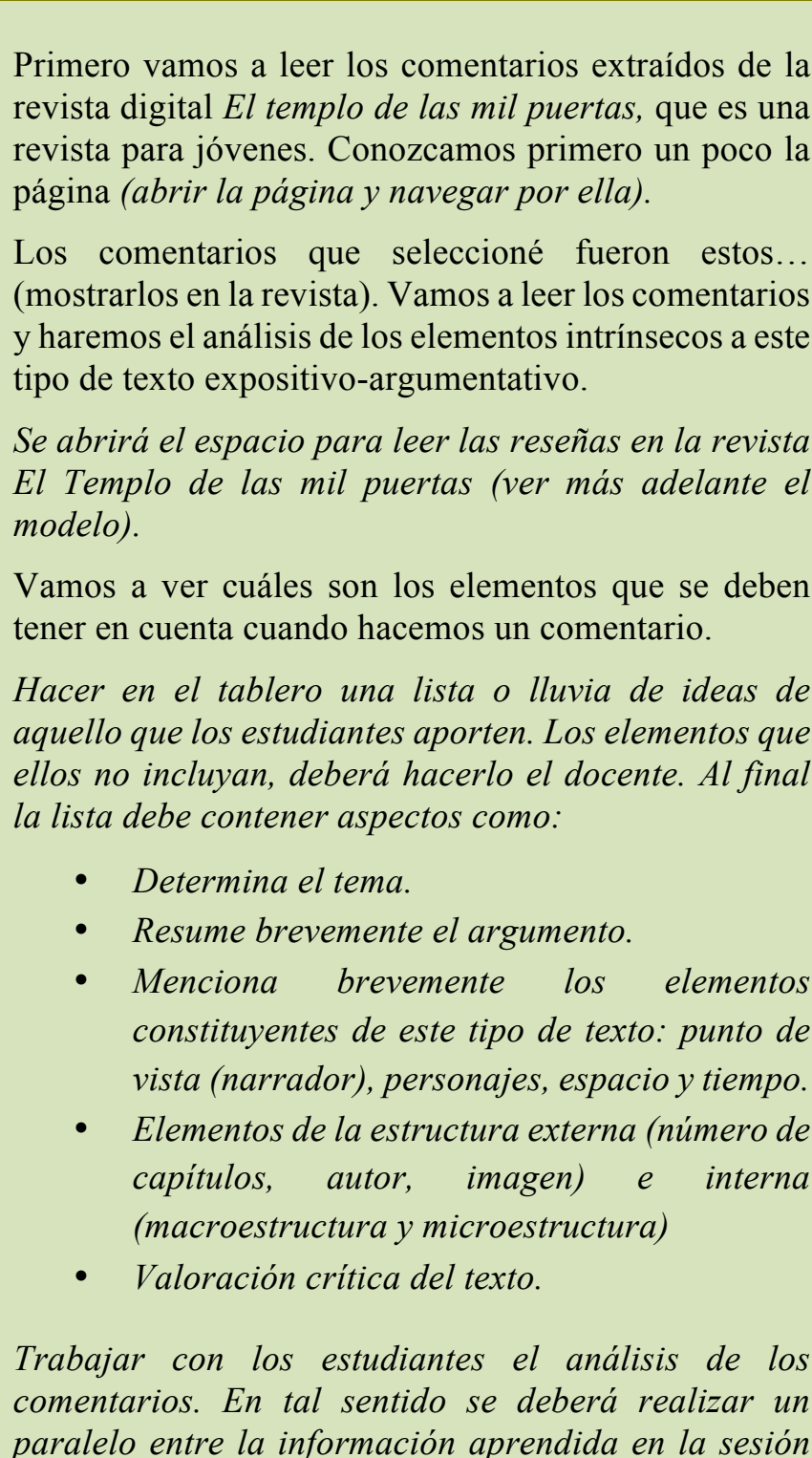 \\
\hline
\end{tabular}




\begin{tabular}{|l|l|l|}
\hline $\begin{array}{l}\text { Momento 2 } \\
\text { Escritura de la nueva } \\
\text { versión } \\
\text { comentario. }\end{array}$ & $\begin{array}{l}\text { anterior (estrategias inferenciales de lectura) y el } \\
\text { material encontrado en cada comentario. }\end{array}$ \\
& $\begin{array}{l}\text { Escribir una } \\
\text { nueva versión } \\
\text { del comentario }\end{array}$ & $\begin{array}{l}\text { Teniendo claras las pautas para la escritura de un } \\
\text { comentario, ahora vamos a realizar las correcciones } \\
\text { necesarias a los nuestros, para finalizar su producción. } \\
\text { Yo les pedí digitar sus comentarios con el fin de hacer } \\
\text { las correciones directamente sobre estos textos y no } \\
\text { tener la necesidad de transcribirlos cada vez que los } \\
\text { tengamos que pulir. } \\
\text { Se abre el espacio para que los estudiantes realicen sus } \\
\text { correcciones teniendo en cuenta las pautas dadas por } \\
\text { la docente. Es importante acompañar a los estudiantes } \\
\text { en un paso a paso. }\end{array}$ \\
\hline
\end{tabular}

Nota: Adaptado de la SD “Escribir como lectores”. Recuperado de: http://bit.ly/1Lri2nz.

\section{Cuadro 6. Rúbrica para evaluar un comentario}

\section{Criterios de autoevaluación}

1. En el encabezado se incluyen los datos mínimos necesarios (nombre del autor, título del libro, editorial, año de publicación y número de páginas)

2. Se evidencia la lectura total del texto.

3. El contenido del libro es presentado en detalle y de manera amena.

4. En los tipos de párrafo desarrollados, las estructuras responden a las intenciones comunicativas enunciadas (descripción, comparación y contraste, argumentación, contrargumentación, etc.).

5. Las oraciones están separadas por punto seguido y reflejan coherencia temática visible. Es evidente que no presentan confusiones en las oraciones.

6. El título de la reseña es llamativo.

7. Hay equilibrio entre las tus opiniones y la información objetiva del texto.

8. Aparece un párrafo con los datos biográficos y bibliográficos claves del autor del libro.

9. El punto de vista personal sobre la obra atrae a leerla.

10. El texto refleja notorios avances en ortografía literal y ortografía acentual.

\section{Bajo Medio Alto}




\section{Cuadro 7. Modelos de comentario en revista El Templo de las mil puertas}

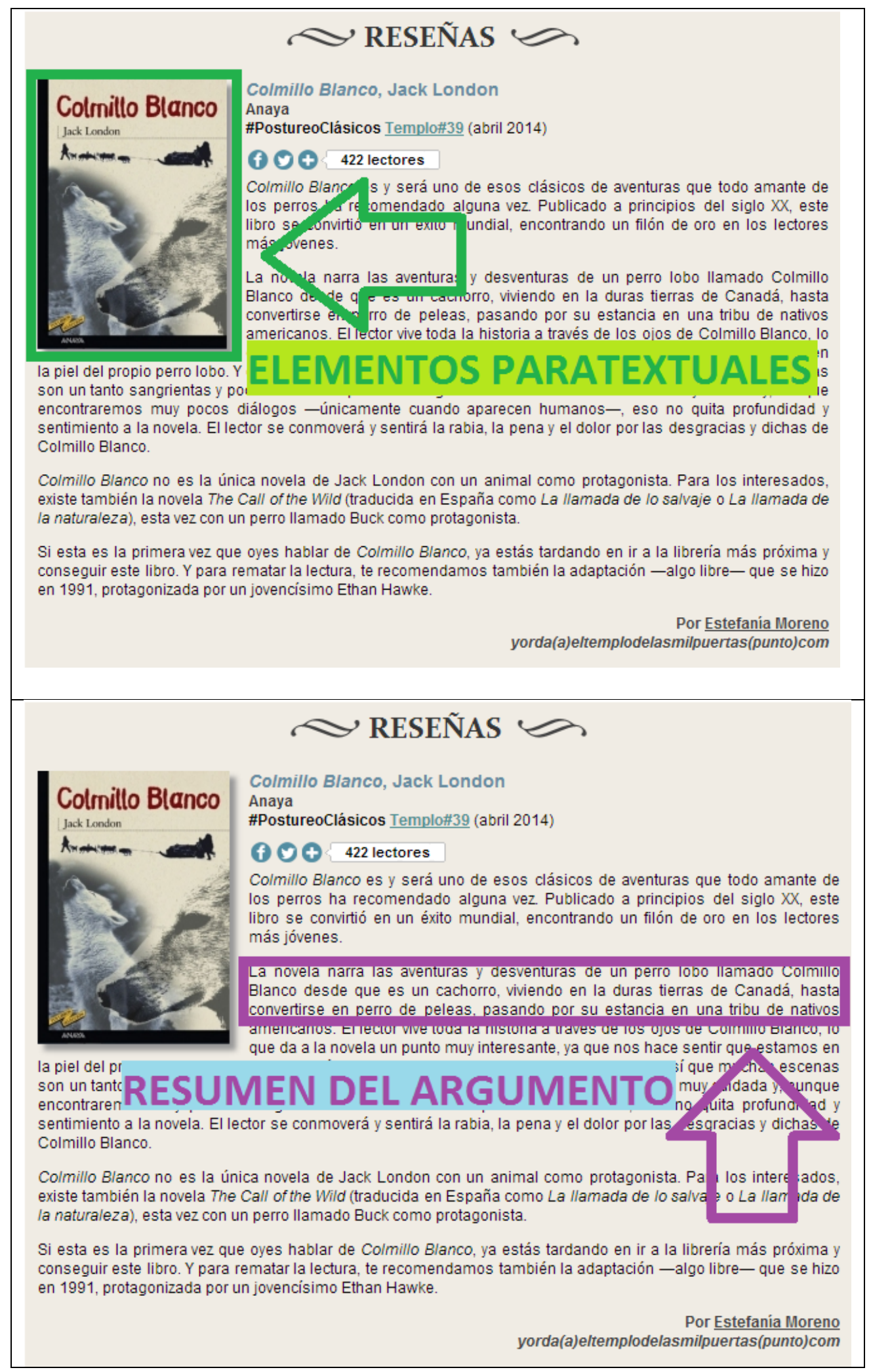




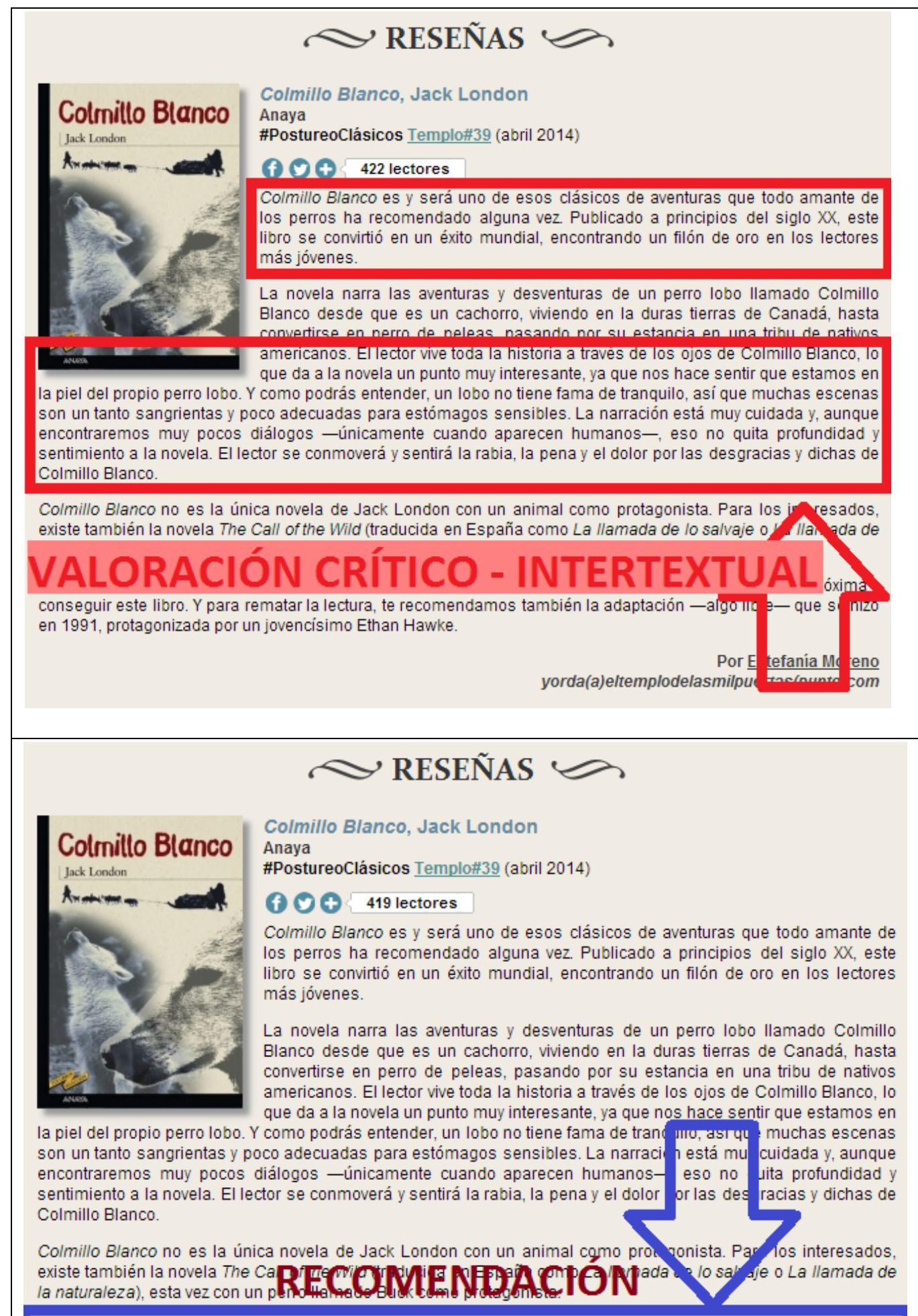

Si esta es la primera vez que oyes hablar de Colmillo Blanco, ya estás tardando en ir a la librería más próxima y conseguir este libro. Y para rematar la lectura, te recomendamos también la adaptación —algo libre — que se hizo en 1991, protagonizada por un jovencísimo Ethan Hawke.

Por Estefanía Moreno yorda(a)eltemplodelasmilpuertas(punto)com

Nota: Adaptado de la SD “Escribir como lectores”. Recuperado de: http://bit.ly/1Lri2nz. 


\begin{tabular}{|l|l|l|l|}
\hline SESIÓN 13 & $\begin{array}{l}3 \\
\text { SUGERIDAS }\end{array}$ & $\begin{array}{l}\text { CONSTRUCCIÓN DE COMPETENCIAS CIUDADANAS: } \\
\text { EMPATÍA }\end{array}$ \\
\hline
\end{tabular}

Profesor, para cerrar la secuencia didáctica dedicada a la novela Era como mi sombra de la escritora colombiana Pilar Lozano, puede aprovechar el taller Los niños piensan la paz (http://bit.ly/1TqYYdF) realizado por la Biblioteca Luis Ángel Arango y el Banco de la República, coordinado por el poeta y educador Javier Naranjo. La propuesta de trabajo durante el taller la puede leer en este enlace: http://bit.ly/1TqZ4ln

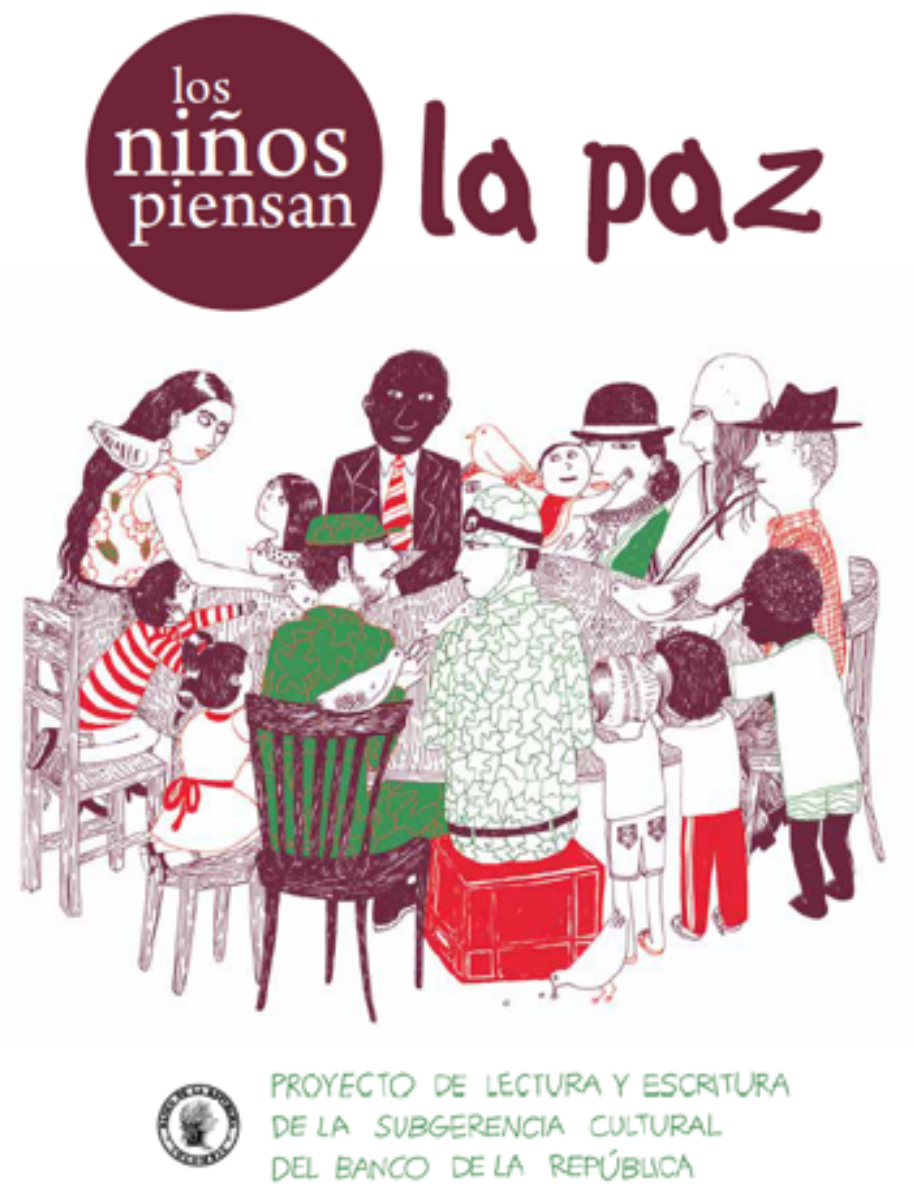

Esta propuesta surge como respuesta a la idea de que los niños viven en una especie de cielo intocado, donde las cosas duran que pasan en Colombia, no los tocan. Al respecto dice Naranjo (2015):

Los niños piensan las armas, las violaciones y los asesinatos en sus barrios. Los niños piensan en el miedo que les da el poder de los adultos que los arrasa y el 
indecible dolor de las tristezas diarias. La falta de trabajo de sus padres y la ausencia de sus padres. Ellos extrañan a sus abuelos que a veces son los únicos que los acompañan.

Sienten la soledad, añoran la visita de sus seres queridos a los albergues de paso donde los dejan, cuando no pueden o no quieren tenerlos, y saben que la guerra empieza con los golpes, los insultos, las agresiones en su hogar, o la indiferencia en el mejor de los casos. Los niños demandan las presencias cercanas, tutelares, las voces que los corrigen y los “acariñan”, según la bella expresión de un chico, en esa yunta feliz entre caricia y cariño (p. 8).

La idea, docente, es que aproveche las actividades propuestas según se ajusten a las condiciones de su curso, de su colegio. Pero al menos sí debería tomar en consideración las las relacionadas con la sección "Esto vivo".

La duración del taller es de tres horas, con 30 asistentes en promedio. Para su ejecución se utilizan diferentes tipos de materiales, entre ellos libros de testimonios ${ }^{121}$, literatura ${ }^{122}$ y algunas palabras en papel, recortadas.

Es esencial que les diga que escriban sin preocuparse por la ortografía, la puntuación, las tildes. Que la actividad no se calificará, que no hay escritos ni buenos ni malos. El centro de esta actividad es emocional, verbal, no busca desarrollar o evaluar competencias de la lengua escrita.

Invite a sus estudiantes a conversar con confianza. A hablar de la situación del país: ¿cómo la sienten?, ¿está bien, mal?, ¿por qué?, ¿qué está pasando en Cuba?, ¿qué es Cuba?, ¿quiénes están hablando? Esto le permitirá elaborar sobre la marcha preguntas adicionales, cuyas respuestas pueden organizar entre todos, sin que nadie se sienta dueño de "la verdad".

La idea es que cada niño o joven exprese lo que siente sobre el significado que para sí tiene la palabra PAZ. Es posible que allí hablen del conflicto armado, de la familia, de la sangre, de las pérdidas, del abandono, del dolor, de la alegría, del hambre, del reclutamiento para la

\footnotetext{
${ }^{121}$ Puede ser el capítulo "Nosotros fuimos criados en la guerrilla", de Crecimos en la guerra (2014), las crónicas periodísticas de Pilar Lozano.

${ }^{122}$ El capítulo 9 de Era como mi sombra (Pilar Lozano). Otros libros más cortos: Tengo miedo (la $2^{\mathrm{a}}$ versión de Ivar da Coll); El árbol triste (Triunfo Arciniegas); Eloísa y los bichos (Jairo Buitrago, Rafael Yockteng).
} 
guerra y la desesperanza (Naranjo, 2015, p. 13).

Docente, de este modo, desde nuestra perspectiva, usted estará desarrollando competencias ciudadanas establecidas en los Estándares básicos de competencias (MEN, 2006, p. 176, 179). Ver cuadro 8.

Cuadro 8. Competencias ciudadanas para desarrollar luego de la lectura de la novela Era como mi sombra (2015), de Pilar Lozano

1. Identifico y supero emociones, como el resentimiento y el odio, para poder perdonar $\mathrm{y}$ reconciliarme con quienes he tenido conflictos. (Competencias emocionales).

2. Analizo críticamente los conflictos entre grupos, en mi barrio, vereda, municipio o país. (Competencias cognitivas).

3. Analizo, de manera crítica, los discursos que legitiman la violencia. (Competencias cognitivas).

4. Expreso empatía ante grupos o personas cuyos derechos han sido vulnerados (por ejemplo, en situaciones de desplazamiento) y propongo acciones solidarias para con ellos. (Competencias emocionales e integradoras).

Nota: Adaptado de Ministerio de Educación Nacional. (2006). Estándares básicos de competencias. Bogotá: Imprenta Nacional.

\section{Procedimiento. Pasos del taller}

1) Se le entrega a cada estudiante una hoja, un lápiz y colores, sacapuntas y borradores para compartir entre varios.

2) A continuación, solicíteles sacar de un par de bolsitas las palabras que previamente ha recortado y que pueden representar el mundo sensible de cada niño o joven.

En una de las bolsitas debe estar el término PAZ. En la otra bolsa palabras como:

\begin{tabular}{|l|l|l|l|l|l|}
\hline hermandad & guerra & miedo & asesinato & amor & familia \\
\hline amistad & orgullo & cariño & abrazar & silencio & policía \\
\hline perdonar & mamá & papá & abuelo & respeto & paramilitar \\
\hline guerrillero & tranquilidad & sueño & soledad & esperanza & reparación \\
\hline carta & pesadilla & secuestro & mentira & desplazamiento & muerte \\
\hline abandono & soberbia & árbol & soldado & violencia & historia \\
\hline morir & mujer & niño & tristeza & reconciliación & conflicto \\
\hline
\end{tabular}


3) Cada estudiante saca tres o cuatro palabras de esa bolsita y la palabra PAZ de la otra.

4) Luego pídales que supongan que usted es un extraterrestre que no sabe el significado de esas palabras y que le ayuden a dar el significado escribiéndolas en su hoja. Haga énfasis en que no miren ningún diccionario (impreso o digital) ni que se copien, pues lo que importa es lo que cada uno piensa y siente. Dé un tiempo prudente para la actividad (pueden ser 15-20 minutos)

5) Ahora propóngales seleccionar la palabra que sientan más, que les duela o les emocione o que los alegre.

6) Invítelos a que a partir de esa palabra seleccionada, escriban una historia real, no inventada, algo que les haya pasado a ellos, su familia, o a unos vecinos, en su barrio (un ejemplo de lo que pueden escribir está en el cuadro 9). Dé 20-25 minutos para realizar la actividad.

7) Pídales autorización para leer todos los textos (o algunos) al azar. Pregúnteles si están de acuerdo en que usted mencione el nombre de quien escribió la historia.

8) Converse con los estudiantes sobre lo que van suscitando las respuestas. Seguramente encontrará que hay textos tristes, perturbadores, alegres.

9) El taller termina con ese momento final de conversación en una atmósfera de tranquila y honda charla, para aliviar un poco los dolores y soledades que suelen aflorar en estos escritos. 
Cuadro 9. Catálogo de palabras con sus significados, escritas por los niños

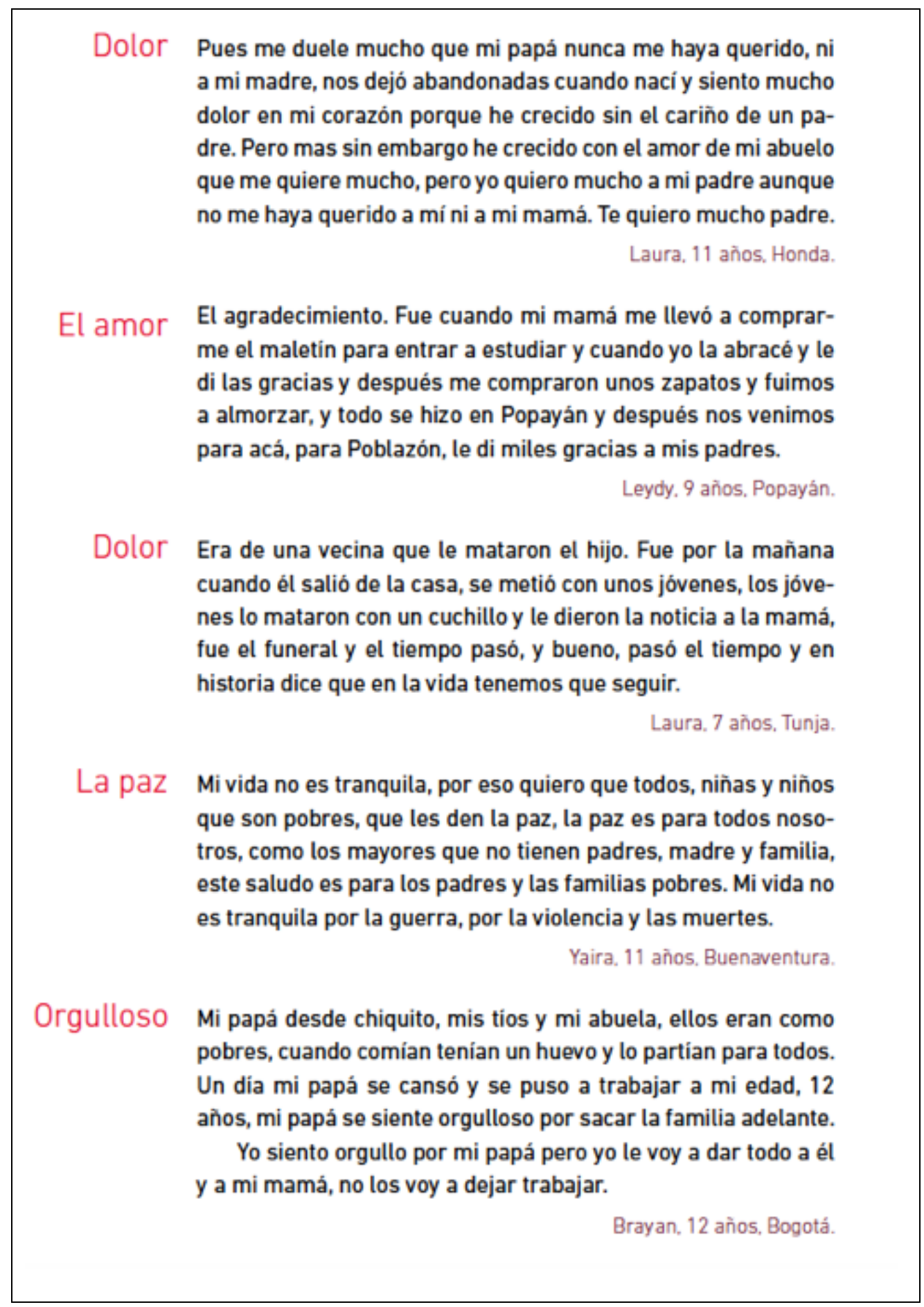

Nota: Adaptado de Naranjo Moreno, J. (2015). Los niños piensan la paz. Bogotá: Banco de la República. 


\section{Condición clave del taller}

Uno de los elementos claves del taller es la tranquilidad que debe reinar, el ambiente distendido que marca diferencia con un salón de clases. La idea es que la disciplina surja por acuerdo entre los estudiantes, y el hecho de que la actividad no es evaluable.

Es fundamental suscitar afinidad y empatía profunda por el sentir del otro, que como dice Naranjo (2015) "así se vuelve también yo" (p. 12). La reacción atenta y cálida ayuda a que cada estudiante se sienta acompañado, escuchado, abrazado. Y que puedan entender que el mundo no es un paraíso, que la guerra que ha vivido Colombia durante más de 5 décadas, entre unos de sus lastres, fue que tocó a los niños y jóvenes (como muy bien lo retrata Pilar Lozano en Era como mi sombra) obligándolos a ejercer la maldad, la sevicia, la perversión. "Estas acciones terribles también existen y eso nos desconcierta porque afecta nuestras miradas preconcebidas y convenientes" dice Naranjo.

Ojalá los niños y jóvenes puedan expresar lo que uno de ellos, Santiago, de Armenia, le respondió al poeta Javier Naranjo cuando este le preguntó: “¿Si pudieras hablar con la guerra qué le dirías? Santiago respondió: "le diría: ¿qué le pasó en la infancia?” (p. 14). 


\section{CONCLUSIONES Y RECOMENDACIONES}




\section{SOBRE NOVELAS JUVENILES}

Las novelas juveniles plantean un ecosistema de lectura particular dentro del circuito de los libros de literatura. Esto en razón de que la mayoría de los libros que leen los jóvenes de educación secundaria pasan por la mediación de docentes. La escuela es el entorno prescriptor por excelencia, con todo lo bueno y lo perjudicial que esto implique.

Estas novelas de prescripción escolar para jóvenes trabajan con un esquema de "lector implícito", es decir, suponen que los muchachos lectores poseen además de una enciclopedia básica, mínimas y determinadas competencias de lectura literaria para formalizar el contrato autor/lector (Iser, 1987).

Los finales de las novelas juveniles tienden a ser abiertos, y tienen la consideración hacia el lector de plantear posibilidades de esperanza para los personajes protagónicos.

Una de las tareas de los editores de literatura juvenil es que los autores cumplan con ciertos parámetros que las colecciones establecen. Uno de ellos, por ejemplo, es que no habrá escenas con sexo explícito o violencia gratuita.

Con ello no se está indicando que son libros de fórmula, sino que las características de estos libros pasan por lo que la escuela valora como "literatura", que desde luego no es un término inequívoco para todos los profesores.

\section{SOBRE LAS DOS NOVELAS ANALIZADAS}

Las novelas estudiadas -Paso a paso, de Irene Vasco, y Era como mi sombra, de Pilar Lozano- incluyen escenas de violencia, pero una estadística de su número, refleja que no son ni corrientes, ni explícitas. En juntas hay un manejo cuidadoso que les permiten contar sórdidos momentos del conflicto armado, sin utilizar el morbo o la displicencia verbal.

Los victimarios en las dos novelas no son protagónicos y son retratados tangencialmente. Las obras se concentran en contar el drama de las víctimas (una joven que sufre el secuestro de su padre; un joven campesino que vista las condiciones de pobreza en que vive su familia, ingresa a la guerrilla) y en lograr que el lector tenga empatía hacia sus tragedias.

Por esa razón, juntas obras recurren al narrador autodiegético (narrador interno en primera persona), porque facilita un diálogo de tú a tú entre el personaje y el lector. Como señala Villanueva (1992; 2006, citado por Pérez Bustamante, 1994), “los signos literarios no 
designan objetos heterónomos, sino que aportan instrucciones para que el lector produzca significado". (p. 422).

Estas obras no pasan de las 100 páginas, a diferencia de los libros sin mediador, como las sagas, o los best sellers juveniles, que pueden ser tomos hasta de 800 páginas. Es apresurado sacar conclusiones al respecto, pero esta restricción en la extensión del paginaje tiene como fin que el joven se concentre no tanto en el relato (el récit), sino en la reflexión a la que el texto quiere invitar, a causa de los dolorosos hechos que se narran en estas obras de tema bélico.

En las dos obras estudiadas resalta el valor del maestro, que en juntos casos cumple el papel del equilibrio, la razón y el respeto hacia las reglas sociales. Se constituyen en referentes sobre todo en el caso dramático del niño protagonista de Era como mi sombra. Cuando el caos y la anomia social, el odio y la brutalidad imperan, los docentes personajes de las obras exponen razones para la cordura y la búsqueda de salidas.

Tanto en Paso a paso como en Era como mi sombra los adolescentes son presentados como sujetos interesados y capaces de comprender el mundo adulto, así estos se muestren reacios a involucrarlos en la realidad compleja del país. En consecuencia, estas obras ayudan a preparar a los muchachos para construir una visión más elaborada de la realidad real y menos basada en la trivialización mediática.

Pese a que los personajes protagónicos de las dos novelas pertenecen a clases sociales diferentes, las autoras se centran en lo que los une: ser víctimas del conflicto armado. Evidentemente el niño guerrillero protagonista de Era como mi sombra sufre una vulnerabilidad mayor, pues ha perdido sus referentes adultos y tiene que convertirse a la fuerza en adulto en medio de la guerra.

\section{SOBRE REPRESENTACIÓN LITERARIA ("MÍMESIS")}

El concepto de mímesis tal como lo expone el gran romanista alemán Eric Auerbach (1950; 2014, p. 522- 525): “interpretación de lo real por la representación literaria o "imitación”, puede ser de gran ayuda para interpretar las novelas realistas colombianas que tocan el conflicto armado y cuyos destinatarios principales son los jóvenes. 
Las obras literarias que tocan el conflicto armado en Colombia se inscriben en el realismo crítico, un concepto proveniente de la estética de Lukács (1963), y desarrollado en América Latina por Ángel Rama (2006).

Juntas novelas cumplen el requisito de las buenas obras que estableció en su particular mímesis Vargas Llosa (1999, 2014): consolidan realidad autónomas, que si bien se basan en la realidad real, crean un mundo particular ficcionalizado, que arrastra a los lectores.

El trabajo de mímesis, de representación de la realidad, que han hecho Paso a paso (1997) y Era como mi sombra (2015) las convierte en obras compactas y de gran nivel estéticoliterario.

\section{SOBRE SECUENCIA DIDÁCTICA Y COMPETENCIA LITERARIA}

El dispositivo pedagógico Secuencia didáctica, por sus características comunicativas integradoras, puede facilitar el desarrollo de la competencia literaria en los jóvenes. Esto si el docente cumple su papel de mediador, ayudándoles a dejar de ser lectores heterónomos y convertirse en lectores autónomos. 


\section{BibliogRAFíA CONSUlTADA}


Abad Colorado, J. (2015). Mirar de la vida profunda. Bogotá: Planeta.

Acosta, C. E. (Coord.) et al. (2011). Pensar la literatura infantil, interpretación a varias voces. Bogotá: Universidad Nacional.

Álvarez, S. (2006). Mapaná. Bogotá: Alfaguara.

Álvarez Correa M. et al. (2002). Guerreros sin sombra. Niños, niñas y jóvenes vinculados al conflicto armado. Bogotá: Procuraduría General de la Nación - Instituto Colombiano de Bienestar Familiar.

Araujo, N. Y Delgado T. (2010). Textos de teorías y críticas literarias. México: AnthroposAUM.

Arciniegas, T. (2008). El árbol triste. Bogotá: Ediciones SM.

Aristóteles (2004). Poética. Buenos Aires: Leviatán.

Auerbach, E. (2014). Mímesis. La representación de la realidad en la literatura occidental. Buenos Aires: FCE.

Barthes, R. (1989). El placer del texto. México: Siglo XXI Editores.

Barrero, S. (marzo de 1998). “La lectura cuasiespontánea”. En: Educación y Cultura (47) pp. 29-33.

Betancourt I. (2010). No hay silencio que no termine. Madrid: Aguilar.

Bombara, P. (2006). El mar y la serpiente. Buenos Aires: Norma.

Bravo Villasante, C. (1989). Ensayos de literatura infantil. Murcia: Universidad de Murcia.

Buitrago, J. y Yockteng R. (2008). Camino a casa. México: FCE.

Buitrago, J. y Yockteng R. (2009) Eloísa y los bichos. Bogotá: Babel Libros.

Caballero, A. (noviembre 8 de 2014). Verdad, justicia, etcétera. En: Semana (422), p. 47. Recuperado de: http://bit.ly/1pqorrx

Camps, A. et al. (2003). Secuencias didácticas para aprender a escribir. Barcelona: Graó.

Carney, T. H. (1992). Enseñanza de la comprensión lectora. Madrid: Morata. 
Castaño A., Valencia S. (2014). Contextos, tipos y formas de la violencia en la literatura infantil y juvenil colombiana. VII Seminario de literatura infantil y juvenil. Cali: Centro Cultural Comfandi.

Castro Caycedo, G. (1990). Colombia X. Bogotá: Planeta.

Castro Caycedo, G. (2001). Con las manos en alto. Bogotá: Planeta.

Cerezales M. N. (septiembre 28 de 2012) De eso no se habla o lo que se habla de eso. En: Memoria Académica. Universidad Nacional de la Plata. Recuperado de: http://bit.ly/1KPTR42

Chambers, A. (2008). Conversaciones. México: FCE.

Charaudeau, P. y Maingueneau D. (2005). Diccionario de análisis del discurso. Buenos Aires: Amorrortu.

Colegio Cambridge (2015). Proyecto Iberoamericano: Escribir como lectores. Recuperado de: http://bit.ly/1Lri2nz.

Coll, I. Da (2012). Tengo miedo. Bogotá: Babel libros.

Colomer, T. (1995). "La adquisición de la competencia literaria". En: Textos. Didáctica de la Lengua y de la Literatura, (4), pp. 19-25.

Colomer, T. (2005). Andar entre libros. México: FCE.

Colomer, T. (2009). Lectura de frontera y frontera de la lectura. En: Colomer, T. (coord.). Lecturas adolescentes (pp. 5-15). Barcelona: Graó.

Colomer, T. (2014). El aprendizaje de la competencia literaria. En: Lomas, C. (coord.). La educación lingüistica, entre el deseo y la realidad. Barcelona: Octaedro.

Cuatrogatos (2016).Premio Fundación Cuatrogatos 2016. Recuperado de: http://bit.ly/1nmrboc

Deas M. (2015). Intercambios violentos y dos ensayos más sobre el conflicto en Colombia. Bogotá: Taurus.

Díaz Barriga, A. (septiembre - diciembre 2013). Secuencias de aprendizaje. ¿Un problema del enfoque de competencias o un reencuentro con perspectivas didácticas? En: Profesorado. 
Revista de currículum y formación del profesorado, 17 (3), 11-32. Recuperado de: http://bit.ly/1eWUOIN

Díaz Plaja, A. (2009). Entre libros: la construcción de un itinerario lector propio en la adolescencia. En: Colomer, T. (coord.). Lecturas adolescentes (pp. 119-149). Barcelona: Graó.

Dolz, J. et al (2013). Producción escrita y dificultades de aprendizaje. Barcelona: Graó.

Duncan, G. (2015). Exclusión, insurrección y crimen En: Contribución al entendimiento del conflicto armado en Colombia (pp. 249-293). Bogotá: Desde Abajo.

Eco, U. (1981). Lector in fabula. Barcelona: Lumen.

El País (febrero 22 de 2007). Entrevista con Pilar Lozano. Recuperado de: http://bit.ly/1U3aMSG

Fandiño Pinilla, F. (noviembre 14 de 2011). Entrevista con la escritora colombiana Pilar Lozano. Recuperado de: http://bit.ly/1TiIKIE

Ferreiro, E. (2013). El ingreso a la escritura y a las culturas de lo escrito. México: Siglo XXI Editores.

Ferry, S. (2012). Violentología: un manual del conflicto colombiano. Bogotá: Ícono Editores.

Friedrich, H. (1969). Tres clásicos de la novela francesa. Buenos Aires: Losada.

Galtung, J. (2003). Paz por medios pacíficos. Paz y conflicto, desarrollo y civilización.

Bilbao: Gernika Gogoratuz.

Galvis S. et al. (2014). Didáctica de la lectura. Bogotá: Alejandría.

Genette G. (1989). Palimpsestos: la literatura en segundo grado. Madrid: Taurus.

Giraldo Ramírez, J. (2015). ¿Política y guerra sin compasión? En: Contribución al entendimiento del conflicto armado en Colombia (pp. 471-519). Bogotá: Desde Abajo.

Gómez García, J. G. (2006). Colombia es una cosa impenetrable. Bogotá: Diente de león.

Gómez García, J. G. y Castilla, J. H. (abril de 1989). El Frente Nacional: el sagrado derecho a la continuidad. En: Investigar, (2), pp. 41-49.

Gómez Jiménez, M. (2015). El derecho a la verdad de las víctimas y de la sociedad. Los 
casos de niños y niñas en Colombia. Bogotá: Unicef - Gente Nueva.

González, L. (2013). Rebeldes, adoptados y transgresores: libros infantiles en la literatura colombiana. Breve recorrido por temáticas realistas. En: Héroe y antihéroe en las literatura hispánicas (pp. 89-97). Liberec: Technická Univerzita v Liberci.

González, L. (2014). Dos abordajes a la realidad latinoamericana desde la literatura para jóvenes. En facsímil.

González Uribe, G. (2002). Los niños de la guerra. Bogotá: Planeta.

Grupo de Memoria Histórica GMH (2013). ¡Basta ya! Memorias de guerra y dignidad. Bogotá: Imprenta Nacional. Recuperado de: http://bit.ly/1S5aKKi

Gutiérrez Girardot, R. (2004). Heterodoxias. Bogotá: Taurus.

Gutiérrez Girardot, R. (2005). "Estratificación social, cultura y violencia en Colombia”. En: Aquelarre (volumen 4, No. 8), pág. 2005. Recuperado de: http://bit.ly/1z1UUoR

Gutiérrez Sanín, F. (2015). ¿Una historia simple? En: Contribución al entendimiento del conflicto armado en Colombia (pp. 521-563). Bogotá: Desde Abajo.

Hanán Díaz, F, (2015). Temas de literatura infantil. Buenos Aires: Lugar Editorial.

Henríquez Ureña (1978). Las corrientes literarias en la América Hispánica. México: FCE.

Hernández Sampieri R. et al. (2006). Metodología de la investigación. México: McGraw Hill.

Hoffman M. L. (1987). La aportación de la empatía a la justicia y al juicio moral. En: Elsenberg, N. y Strayer J. (coord.). La empatía y su desarrollo (pp. 26-42). Bilbao: Desclé de Brouwer.

Human Rights Watch (2003). Aprenderás a no llorar. Bogotá: Gente Nueva.

Iser, W. (1987). El acto de leer. Madrid: Taurus.

Jaramillo Vélez, R. (2013). Modernidad, nihilismo y utopía. Bogotá: Siglo del Hombre Universidad de Antioquia.

Jünger, E. (2003). El corazón aventurero. Barcelona: Tusquets.

Hegel, G. W. (2006). La fenomenología del espíritu. Valencia: Pretextos. 
HispanTV (Productor). (2012). Reclutamiento forzado. Recuperado de: http://bit.ly/1LtsNm8

Lafuente, J. (noviembre 20 de 2015). Iván Márquez: "Queremos decirles a los colombianos: Cometimos errores". En: El País, p. 17. Recuperado de: http://bit.ly/11AAZuz.

Litwin E. 1997). Las configuraciones didácticas. Una nueva agenda para la enseñanza superior. Buenos Aires: Paidós.

Lluch, G. (2010). Las nuevas lecturas deslocalizadas de la escuela. En: Lluch, G. (coord.), Las lecturas de los jóvenes, (pp. 105-128). Barcelona: Anthropos.

Londoño Vega, P. et al. (2012). Los niños que fuimos: huellas de la infancia en Colombia. Bogotá: Banco de la República. Recuperado de: http://bit.ly/1oWGpBs

Lozano, J. (febrero 16 de 2015). Reclutamiento de menores... ; a partir de 17! Recuperado de: http://bit.ly/1QkSaOg

Lozano, P. (2014). Crecimos en la guerra. Bogotá: Panamericana.

Lozano, P. (2015). Era como mi sombra. Bogotá: Ediciones SM.

Lukács, G. (1963). Estética y poética. Valencia: Nau libres.

Lukács, G. (2010). Teoría de la novela. Buenos Aires: Godot.

Leal Quevedo, F. (2009). El mordisco de la medianoche. Bogotá: Ediciones SM.

Marín, M. (2009). Conceptos clave: gramática, lingüística, literatura. Buenos Aires: Aique. Mendoza Fillola, A. (2012). Leer hipertextos: del marco hipertextual a la formación del lector literario. Barcelona: Octaedro.

Mendoza Fillola, A. (enero de 2013). De la intertextualidad a los hipertextos. En: Textos. Didáctica de la lengua y de la literatura, (62), pp. 11-23.

Meneses, G. (2011). La luna en los almendros. Bogotá: Ediciones SM.

Ministerio de Educación Nacional (2006). Estándares básicos de competencias en Lenguaje, Matemáticas, Ciencias y Ciudadanas. Bogotá: Imprenta Nacional. Recuperado de: $\underline{\text { http://bit.ly/1TUBsWD }}$ 
Ministerio de Educación Nacional (2015). Derechos básicos de aprendizaje. Bogotá: Imprenta Nacional. Recuperado de: http://bit.ly/21MQ0ZQ

Molano Bravo, A. (2015). Fragmentos de la historia del conflicto armado (1920-2010). En:

Contribución al entendimiento del conflicto armado en Colombia (pp. 565-625). Bogotá:

Desde Abajo.

Montaña, F. (2013). El gato y la madeja perdida. Bogotá: Alfaguara.

Naranjo Moreno J. (2015). Los niños piensan la paz. Proyecto de lectura y escritura de la Subgerencia Cultural del Banco de la República. Bogotá: Banco de la República. Recuperado de: http://bit.ly/1TqZ4ln

Ong, W. J. (2009). Oralidad y escritura: Tecnologías de la palabra. México: FCE.

Ospina, C. E. (2013). Irene Vasco en la Biblioteca Virtual. Biblioteca Luis Ángel Arango. Recuperado de: http://bit.ly/1LEFYWB

Pachón C., X. (febrero 2 de 2009). La infancia perdida en Colombia: los menores en la guerra. En: Georgetown University. Working Paper Series, (15), pp. 3-21.

Pécaut, D. (2000). Guerra contra la sociedad. Bogotá: Espasa.

Peña Borrero, L. B. (2002). La lectura en contexto. Bogotá: Pirls-Icfes.

Pérez L. E. y Arizmendi D. (2008). Siete años secuestrado por las Farc. Caracas: Aguilar.

Pérez Abril M. y Rincón, G. (2009). Actividad, Secuencia didáctica y pedagogía por Proyectos: tres alternativas para la organización del trabajo didáctico en el campo del lenguaje. Bogotá: Cerlalc. Recuperado de: http://bit.ly/1Lho4U7.

Pérez Abril, M. et al. (2010). Referentes para la didáctica del lenguaje. Bogotá: Secretaría de Educación de Bogotá.

Petit, M. (1999). Nuevos acercamientos a los jóvenes y la lectura. México: FCE.

Petit, M. (2015). Leer el mundo. Buenos Aires: FCE.

Pipkin M. (2010). Prácticas de lectura y escritura académicas. Córdoba: Comunicarte.

Piaget, J. (1993). La representación del mundo en el niño. Madrid: Morata. 
Pizarro E. (2015). Una lectura múltiple y pluralista de la historia. En: Contribución al entendimiento del conflicto armado en Colombia (pp. 17-105). Bogotá: Desde Abajo.

Pizarro E. (1991). Las Farc. De la autodefensa a la combinación de todas las formas de lucha. 1949-1966. Bogotá: Tercer Mundo.

Quintero, C. (2005). La literatura: una máquina para enseñar a escribir. Cali: Gobernación del Valle - Universidad del Valle.

Rama, A. (2006). Crítica literaria y utopía en América Latina. Medellín: Universidad de Antioquia.

Ramírez Orozco (2013). La paz sin engaños. Bogotá: Universidad de la Salle.

Rancière, J. (2009). El reparto de lo sensible. Santiago: Libros Arce Lom.

Restrepo, J. D. (junio 28 de 2014). Los niños sin infancia. En: Vida nueva, (27), p. 19. Recuperado de: http://bit.ly/2134eW3.

Reyes, A. (1983). La experiencia literaria. México: FCE.

Reyes, Y. (2008). Los agujeros negros. Bogotá: Alfaguara.

Reyes Mate, M. (2008). La herencia del olvido. Madrid: Errata Naturae.

Reyes Mate, M. (2010). Aut lex, aut vis valet. En: Valladolid Bueno, T. (coord.). Reyes Mate. Memoria histórica, reconciliación y justicia. (pp. 45-56). Barcelona: Anthropos.

Reyes Mate, M. (2011). Tratado de la injusticia. Barcelona: Anthropos.

Ricoeur, P. (2004). Tiempo y narración. México: Siglo XXI Editores.

Robledo B. H. (2010). Gran diccionario de autores latinoamericanos de literatura infantil y juvenil. Bogotá: Fundación SM. Recuperado de: http://bit.ly/1Qy10TJ

Rosenblatt L. M. (1996). "La teoría transaccional de la lectura”. En: Textos en contexto, No. 1. Buenos Aires: Lectura y vida.

Rosenblatt L. M. (2002). La literatura como exploración. México: FCE.

Rudell R. B. (1995). Those influential literacy teachers: meaning negociators and motivation builders. En: The Reading Teacher, 6 (48), 454-463. 
Ruiz Silva et al. (2010). La formación de competencias ciudadanas. Recuperado de: http://bit.ly/1TUHgPZ

Salazar, A. (2002). No nacimos pa' semilla. Bogotá: Planeta.

Samper, A. (julio de 2013). El secuestro de la Chiva. En: El Malpensante, (143), pp. 7-72.

Recuperado de: http://bit.ly/1QqlYWI

Sánchez Lozano, C. (enero-junio de 1997). Los jóvenes y su rostro de dolor. En: Revista Latinoamericana de Literatura Infantil y Juvenil, (5), pp. 51-53.

Sánchez Lozano, C. (marzo de 2004). ¿Por qué los jóvenes leen mal?. En: Educación y Biblioteca, (143), pp. 64-68.

Sánchez Lozano, C. (2005). La crónica periodística contemporánea en Colombia. Recuperado de: http://bit.ly/1mi3CfG.

Sánchez Lozano, C. (febrero de 2013). Formación de lectores, competencia literaria y evaluación: un reto pendiente. En: Ruta maestra (2), pp. 49-54. Recuperado de: http://bit.ly/1PZUvc8

Sánchez Lozano, C. (2013). Hacia la mayoría de edad: una aproximación a los hitos de la literatura infantil y juvenil colombiana 1950-2000. En: Hitos de la literatura infantil y juvenil iberoamericana. Bogotá: Fundación SM y Biblioteca Luis Ángel Arango. Recuperado de: http://bit.ly/1FkPwgS.

Sánchez Lozano, C. (2014). Prácticas de lectura en el aula. Orientaciones didácticas para docentes. Bogotá: Ministerio de Educación Nacional - Cerlalc. Recuperado de: http://bit.ly/1xe1ckv

Sánchez Lozano, C. (junio de 2015). La academia repara en la literatura para niños. En:

Boletín Cultural y Bibliográfico, 49 (88), 161-162. Recuperado de: http://bit.ly/1KMHMHd

Sánchez Lozano, C. (2015). Era como mi sombra. Guía de aula. Bogotá: Ediciones SM. Recuperado de: http://bit.ly/1LuVLSG

Sánchez Lozano, C. (febrero 8 de 2016). Entrevista a Irene Vasco sobre Paso a paso [audio en podcast]. Recuperado de: http://bit.ly/21X4CWP 
Sánchez Lozano, C. (febrero 6 de 2016). Entrevista a Pilar Lozano sobre Era como mi sombra [audio en podcast]. Recuperado de: http://bit.ly/1p3bYtg

Sarland, C. (2003). La lectura en los jóvenes: cultura y respuesta. México: FCE.

Schujer, S. (2001). Las visitas. Buenos Aires: Alfaguara.

Skármeta, A. y Ruano A. (2000). La composición. Caracas: Ekaré.

Sierra, A. (13 diciembre de 2015). El argumento moral. En: El Tiempo, p. 19A. Recuperado de: http://bit.ly/10814cM

Silva, G. (abril 25 de 2013). Entrevista a Irene Vasco. Recuperado de: http://bit.ly/1mi3CfG Silva Díaz, M. C. (2009). Entre el escrito y uno mismo: realismo juvenil y construcción de identidades. En: Colomer, T. (coord.). Lecturas adolescentes (pp. 185-195). Barcelona: Graó. Tabernero, R. (2003). Hacia una definición del narrador. Algunas notas acerca de la focalización en los relatos dirigidos a los lectores infantiles. En: Cano Vela, A. et. al (coord.) Canon, literatura infantil y juvenil y otras literaturas (pp. 535-547). Cuenca: Universidad de Castilla La Mancha

Torres Duarte, J. D. (2013). La literatura entabla diálogos. Entrevista a Irene Vasco. Recuperado de: http://bit.ly/1TYBrzE

Triana, L. M. (2008). Investigación literaria. Bogotá: Universidad Santo Tomás.

Triviño, C. (enero 18 de 2016). Era como mi sombra, Pilar Lozano y su compromiso con la infancia. Recuperado de: http://bit.ly/1Qej309

Universidad Santo Tomás (2013). Lineamientos para la investigación. Maestría en Estudios Literarios. Bogotá: Usta.

Uribe A. M. V. (diciembre de 1990). Matar, rematar, contramatar. En. Controversia-Cinep (159-160), pp. 5-210.

Valencia. L. (2014). Mis años de guerra. Bogotá: Aguilar.

Vargas Llosa (2014). La verdad de las mentiras. Barcelona: Debolsillo.

Vasco, I. (1997). Paso a paso. Vuelve papá. Bogotá: Panamericana.

VV. AA. (2013), Geografia del conflicto armado. Bogotá: Corporación Nuevo Arco Iris. 
VV.AA. (2015). Contribución al entendimiento del conflicto armado en Colombia. Bogotá:

Desde Abajo. Recuperado de: http://bit.ly/1U11pha

Vygotski (2000). El desarrollo de los procesos psicológicos superiores. Baarcelona: Crítica.

Villamizar, D. (1997). Sueños de abril. Imágenes en la historia del M-19. Bogotá: Planeta.

Villanueva, D. (2004). Teorías del realismo literario. Madrid: Biblioteca Nueva.

Wills, M. E. (2014). Aprender a ser humano. Recuperado de: http://bit.ly/1TADLxP

Wills, M. E. (2015). Los tres nudos de la guerra colombiana. En: Contribución al entendimiento del conflicto armado en Colombia (pp. 813-859). Bogotá: Desde Abajo.

Wolcott H. F. (2006). Mejorar la escritura de la investigación cualitativa. Medellín: Universidad de Antioquia.

Zubiría, S. (2015). Dimensiones políticas y culturales en el conflicto colombiano. En: Contribución al entendimiento del conflicto armado en Colombia (pp.197-247). Bogotá: Desde Abajo. 


\section{AneXos}


ANEXo 1

ESTADO DEL ARTE SOBRE EL CONFLICTO ARMADO EN LA LITERATURA JUVENIL 


\section{RESUMEN DEL ESTADO DEL ARTE}

La llegada al núcleo de la pregunta que guía esta investigación tuvo varios pasos complejos discutidos y acordados con el tutor, profesor Rubén Darío Vallejo. Fue necesario primero desglosar la categoría conceptual "conflicto armado", que tiene su origen en las ciencias sociales. Luego aclarar qué obras de la literatura infantil y juvenil colombiana contemporánea estaban relacionadas con el conflicto armado. Posteriormente seleccionar dos obras incluidas en la categoría "novela juvenil" que estuvieran dentro de la corriente realista. Finalmente se establecieron los criterios para diseñar una propuesta de secuencia didáctica que permitiera a docentes de grados $7^{\circ}$ y $8^{\circ}$ desarrollar competencia literaria con sus estudiantes a partir de la lectura de una de esas novelas.

\section{Trabajos Referidos Al CONFLicto ARMAdo En COLOMBIA}

Son muchísimos y provenientes de diversas especialidades de las ciencias humanas, en particular de la historiografía, la sociología, los estudios políticos, el derecho. Un corpus hecho a través del catálogo de la Biblioteca Luis Ángel Arango, luego de introducir la palabra clave "conflicto armado Colombia", arrojó 1520 registros sobre el tema.

Para efectos de los objetivos de esta investigación (que no es histórica ni política ni jurídica, sino literaria) seleccionamos centralmente dos investigaciones extensas que recogen informes globales sobre el conflicto armado entre 1958 y 2012, y otra bibliografía de apoyo que se cita más adelante:

¡Basta ya! Memorias de guerra y dignidad. (2013). Esta investigación informadísima es el resultado del trabajo realizado durante 5 años por el Grupo de Memoria Histórica, asociado al $\mathrm{CMH}$, dirigido por el profesor Gonzalo Sánchez y en el que participaron más de 60 investigadores. Se consultaron en particular los capítulos 1 y 4, dedicados respectivamente a describir las modalidades de violencia y los impactos y daños causado por el conflicto armado. Del capítulo 1 extrajimos un listado de los delitos asociados al conflicto armado, que nos sirvió de base para buscar libros de literatura infantil y juvenil relacionados que tocaran esos temas: asesinatos selectivos, masacres, sevicia y tortura, desaparición forzada, secuestro y toma de rehenes, desplazamiento forzado, despojo y extorsiones, violencia sexual, reclutamiento ilícito de menores, acciones bélicas, minas antipersonal, ataques a bienes civiles, atentados terroristas. 
Contribución al entendimiento del conflicto armado en Colombia (2015). Este extenso trabajo recopila los 12 informes que un grupo de académicos de diversas procedencias ideológicas realizaron para la Comisión Histórica del Conflicto y sus Víctimas, que surgió como parte de los acuerdos entre el Gobierno y las Farc en La Habana. Leímos con especial cuidado -para estudiar el tema del secuestro y el reclutamiento forzado de menores- los ensayos de Jorge Giraldo Ramírez, Gustavo Duncán, Francisco Gutiérrez Sanín y María Emma Wills. También aportó información conceptual e histórica básica la relatoría hecha por el profesor y consultor Eduardo Pizarro.

También consultamos el trabajo de un reconocido historiador inglés, estudioso de las élites políticas en Colombia: Malcom Deas: Intercambios violentos y dos ensayos más sobre el conflicto en Colombia (2015).

Sobre la conformación y perfil ideológicos de los grupos guerrilleros en Colombia examinamos estos libros: Las Farc. De la autodefensa a la combinación de todas las formas de lucha. 1949-1966 (1991) de Eduardo Pizarro; Sueños de abril. Imágenes en la historia del M-19 (1997) de Darío Villamizar; Mis años de guerra (2014), de León Valencia, antiguo militante del Eln y hoy columnista de Semana e investigador independiente.

Entre los portales electrónicos de corte periodístico independiente son básicos para hacerse una idea equilibrada del conflicto armado: http:/www.verdadabierta.com/ y http://lasillavacia.com/.

\section{TrABAJOS REFERIDOS A LA VIOLENCIA EN LA NARRATIVA JUVENIL}

En esta sección consultamos fundamentalmente:

El ensayo "Contextos, tipos y formas de violencia en la literatura infantil y juvenil colombiana" de Alice Castaño y Silvia Valencia, que presentaron como parte de su tesis de maestría en Literatura infantil en la Universidad Autónoma de Barcelona en 2014. El trabajo es muy útil porque elabora un corpus de libros de literatura infantil cuya temática es la violencia en Colombia desde 1990 a 2013. Castaño y Valencia encontraron 12 libros representativos y los clasificaron según las clases de violencia que establecieron como categorías de análisis - directa, estructural y cultural-, siguiendo a Johan Galtung (2003): 


\begin{tabular}{|c|c|c|}
\hline $\begin{array}{c}\text { Pelea en el parque (Evelio } \\
\text { Rosero) }\end{array}$ & $\begin{array}{l}\text { Los once (Andrés Cruz, } \\
\text { Miguel y José Luis } \\
\text { Jiménez) }\end{array}$ & $\begin{array}{c}\text { El mordisco de la } \\
\text { medianoche (Francisco Leal } \\
\text { Quevedo) }\end{array}$ \\
\hline $\begin{array}{c}\text { El árbol triste (Triunfo } \\
\text { Arciniegas) }\end{array}$ & $\begin{array}{l}\text { Los agujeros negros } \\
\text { (Yolanda Reyes) }\end{array}$ & Tengo miedo (Ivar da Coll) \\
\hline $\begin{array}{c}\text { Camino a casa (Jairo } \\
\text { Buitrago - Rafael } \\
\text { Yockteng) }\end{array}$ & $\begin{array}{c}\text { La muda (Francisco } \\
\text { Montaña) }\end{array}$ & $\begin{array}{l}\text { La luna en los almendros } \\
\text { (Gerardo Meneses) }\end{array}$ \\
\hline Paso a paso (Irene Vasco) & $\begin{array}{l}\text { No comas renacuajos } \\
\text { (Francisco Montaña) }\end{array}$ & $\begin{array}{c}\text { Mambrú perdió la guerra } \\
\text { (Irene Vasco) }\end{array}$ \\
\hline
\end{tabular}

Dos ensayos de la profesora Lillyam González, investigadora que hace su tesis de doctorado en la Universidad Carolina de Praga: y "Rebeldes, adoptados y transgresores: libros infantiles en la literatura colombiana. Breve recorrido por temáticas realistas" (2013) y "Dos abordajes a la realidad latinoamericana desde la literatura para jóvenes" (2014). Nos fueron muy útiles porque ella también tiene interés en estudiar el tema de la violencia en la literatura infantil y juvenil colombiana, si bien su trabajo se extiende a todo lo largo del siglo XX y está enfocado, sobre todo, a analizar aspectos ideológicos en estas obras.

\section{Trabajos referidos a la novela juvenil sobre el conflicto armado}

Con base en el catálogo de la Biblioteca Luis Ángel Arango se hizo selección de obras de literatura juvenil que tocaran temas relacionados con el conflicto armado en Colombia. Se seleccionaron 13 y posteriormente -para el objeto de esta investigación- se realizó una nueva selección de obras literaria a la luz de que solo nos enfocaríamos en dos crímenes asociados con el conflicto armado: secuestro y reclutamiento ilícito de menores. Finalmente se seleccionaron dos novelas juveniles: Paso a paso de Irene Vasco y Era como mi sombra de Pilar Lozano. Con base en la segunda obra se realizó la Secuencia didáctica.

\section{Trabajos referidos a teoría literaria sobre la novela juvenil}

Aquí consultamos un conjunto de trabajos que se han enfocado en estudiar las formas de ficcionalización (de mímesis) que realizan las novelas juveniles, de base histórica.

Ensayo "Hacia la mayor de edad: una aproximación a los hitos de la literatura infantil y juvenil colombiana 1950-2000” (2013) de Carlos Sánchez Lozano, que recoge el estudio de 
15 obras canónicas de la literatura infantil colombiana escritas durante la segunda mitad del siglo XX y en el que se valora los procesos de "literariedad" que realizan.

Mímesis. La representación de la realidad en la literatura occidental, Eric Auerbach. Se revisó el Epílogo (1950; 2014, p. 522- 525) en el que el gran filólogo alemán resume su tesis de la "interpretación de lo real por la representación literaria o "imitación” (mímesis).

La verdad de las mentiras (1999, 2014), de Mario Vargas Llosa, para observar de qué modo la narración periodística o histórica se diferencia de la narración ficcional.

Teoría de la novela $(1920,2010)$, de G. Lukács para revisar lo concerniente al "héroe problemático", pues nos interesaba utilizar esta categoría en al análisis de los dos personajes protagónicos de Paso a paso y de Era como mi sombra.

Textos de teorias y críticas literarias (2010), un tomo coordinado por las profesoras Nara Araújo y Teresa Delgado, de la Universidad Autónoma Metropolitana, en que recogen capítulos o secciones de obras clave de la teoría literaria desde Shklovski y Frye, pasando por Jakobson, Bajtin y Barthes hasta Iser, Eagleton y Umberto Eco.

\subsection{Trabajos referidos a qué es una secuencia didáctica}

En esta sección fueron fundamentales los aportes de un libro y un ensayo.

El libro, Producción escrita y dificultades de aprendizaje (2013), del profesor Joaquim Dolz y su equipo de investigación de la Universidad de Ginebra, a quienes se debe la teorización sobre las características de una secuencia didáctica.

El ensayo "Secuencias de aprendizaje. ¿Un problema del enfoque de competencias o un reencuentro con perspectivas didácticas?” (2013), escrito por el profesor mexicano Ángel Díaz Barriga, en el que ubica las secuencias didácticas en un marco histórico del aprendizaje y dentro del constructivismo como corriente pedagógica moderna. 
ANEXO 2

entrevistas Realizadas a IRene Vasco Y Pilar LOZANO 


\section{Preguntas de aVance Para la entrevista}

1) ¿Cómo comenzaron las cosas? El punto cero en que dijiste: "Voy a escribir una novela que narre la historia..."

2) ¿Cuánto tiempo te llevó escribirla?

3) ¿Qué emociones te acompañaban mientras la escribías?

4) ¿Cómo fueron esos días de escritura. ¿Había un hecho de fondo que te impactara? ¿Una persona?

5) ¿Entre tus objetivos estaba el de visibilizar el sufrimiento de las víctimas?

6) ¿Qué capítulo fue más difícil de escribir?

7) Una de los aspectos que le dan solidez a la novela es la voz del narrador. El relato está narrado en primera persona. ¿Salió así o hubo prueba con otro tipo de narrador? ¿Qué fuerza, en tu opinión, le da a la historia narrarla en primera persona?

8) Al leer la historia, tengo la impresión de que hubo un trabajo periodístico previo, una entrevista con la persona que se convertiría en protagonista. ¿Es así? O hubo otro procedimiento creativo?

9) El joven protagonista recupera al final de la obra su identidad, su derecho a disentir. Siento viva, poderosa, la voz de este personaje...

10) Hablemos de la figura del docente, que aunque está en la sombra por momentos, vuelve y sale a flote y cumple un papel especial. ¿Cómo enriquece el maestro la trama de la novela?

11) En la novela evitas mostrar escenas explícitas de violencia, salvo cuando es estrictamente necesario. ¿Tienes un punto de vista sobre esto?

12) Me gusta la imagen de carátula. De inmediato te ubica en el centro de la trama...

13) ¿El manuscrito, el borrador lo leyó previamente alguien? ¿Qué te dijo después de leerlo?

14) ¿Cuándo dijiste: "El libro está cerrado”, ni una letra más?

15) Me gusta cómo el libro está editado. ¿Cómo fue la relación con el editor? ¿Qué dijo cuando lo recibió?

16) Tu obra critica a los señores de la guerra en Colombia. ¿No temes que te acusen de hacer literatura de denuncia, literatura dominada por la emoción? 
17) El próximo 23 de marzo de 2016 -esperemos- se debe firmar un acuerdo entre el Gobierno -representante del Estado y de la sociedad civil- con las Farc. ¿Qué te evoca todo esto en relación con los hechos contados en el libro?

18) ¿Qué han dicho los lectores -y también la crítica especializada- sobre la obra?

19) ¿Ser promotora de lectura y trabajar con jóvenes te benefició a la hora de escribir la novela?

20) ¿Has vuelto a releer el libro? Le cambiarías algo?

21) Dentro de tu obra literaria, ¿qué representa este libro?

22) ¿Qué otras obras sobre el conflicto armado valoras?

23) ¿Te sientes feliz, tranquila, de haber escrito este libro?

\section{Podcast. Enlaces con las entrevistas.}

- Entrevista a Irene Vasco (autora de Paso a paso)

Podcast: http://bit.ly/1U7WakJ

You Tube: http://bit.ly/21X4CWP

- Entrevista a Pilar Lozano (autora de Era como mi sombra)

Podcast: http://bit.ly/1Qy52h5

You Tube: http://bit.ly/1p3bYtg 
ANEXo 3

ÍNDICES DE ESQUEMAS, CUADROS E IMÁGENES 